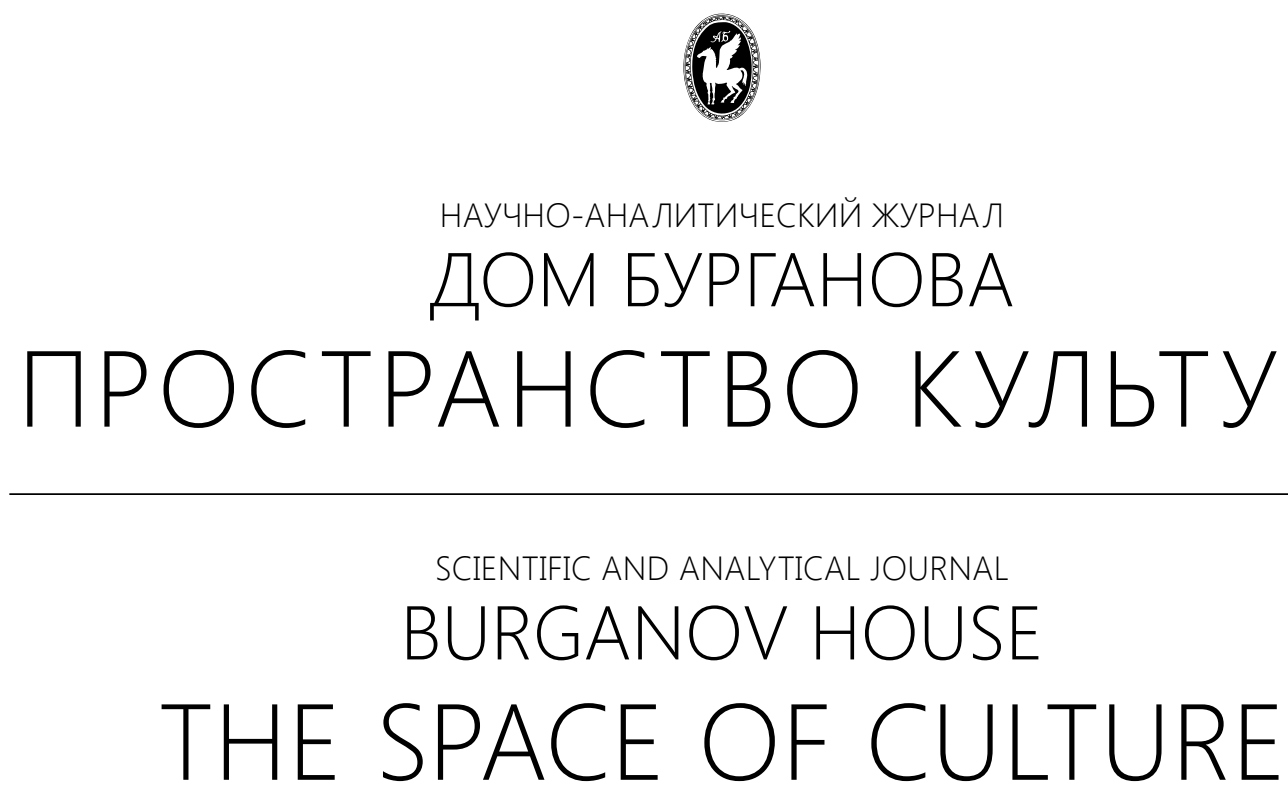

По рекомендации экспертного совета Высшей аттестационной комиссии Министерства образования и науки Российской Федерации журнал входит в «Перечень ведущих рецензируемых научных журналов и изданий, в которых должны быть опубликованы основные научные результаты диссертации на соискание ученой степени доктора и кандидата наук» 
The Editorial Board:

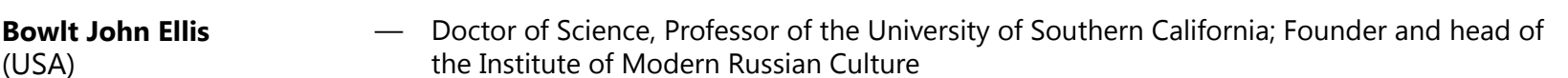

(U) (Russia)

Doctor of Science, Professor of Strog
member of Russia Academy of Arts

Burganova Maria A.

Doctor of Science, Professor of Stroganov Moscow State Art Industrial Academy, Fullmember of Russia Academy of Arts

— Doctor of Science, Professor of Guangzhou Academy of fine arts

Gao Meng

(China)

Glanc Tomáš

(Germany)

Kravetsky Alexander G.

(Russia)

Kojo Sano
(Japan)

Misler Nicoletta

(Italy)

Pan Yaochang

(China)

Pavlova Irina B.

(Russia)

Perelshtein Roman M.

(Russia)

Pletneva Alexandra A.
(Russia)

Pociechina Helen

(Poland)

Pruzhinin Boris I.

(Russia)

Ryzhinsky Alexander S.

Sahno Irina M.

(Russia)

Smolenkov Anatoly P.

(Russia)

Smolenkova Julia A.

Tanehisa Otabe

(Japan)

Tsivian Yuri G. - Doctor of Science of The Research Institute of East European University of Bremen
(Germany), and assistant professor of The Charles University (Czech Republic)

- Candidate of Sciences, research associate of Russian Language Institute of the Russian

- Professor of Toho Gakuyen University of Music

- Professor of Modern East European Art at the Instituto Universitario Orientale, Naples

- Professor of the Department of Art History and Art Theory of College of Fine Arts in Shanghai University; member of the Academic Committee of the Shanghai University

- Doctor of Philology, Senior Researcher of Institute of World Literature of the Russian Academy of Sciences

- Doctor of Arts, All-Russia State Institute of Cinematography named after S. A. Gerasimov

- Candidate of Sciences, research associate of Russian Language Institute of the Russian Academy of Sciences

- Doctor of Science; Professor of the University of Warmia and Mazury in Olsztyn

- Doctor of Sciences, Professor, editor-in-chief of the Journal Problems of Philosophy

- Doctor of Science, Professor of Gnesins Russian Academy of Music

- Doctor of Sciences, Professor of Peoples' Friendship University of Russia

- Candidate of Sciences, Professor of Stroganov Moscow State Art Industrial Academy, full-member of Russia Academy of Arts Academy

- Doctor of Science, Professor, Head of Department of Aesthetics and Theories of Art. The University of Tokyo

- Doctor of Science, Professor, University of Chicago, Departments: Cinema and Media
SCIENTIFIC AND ANALYTICAL

SPACE OF CULTURE"

No. 4

- Candidate of Sciences, associate professor of Stroganov Moscow State Art Industrial Studies, Art History, Slavic Languages and Literatures

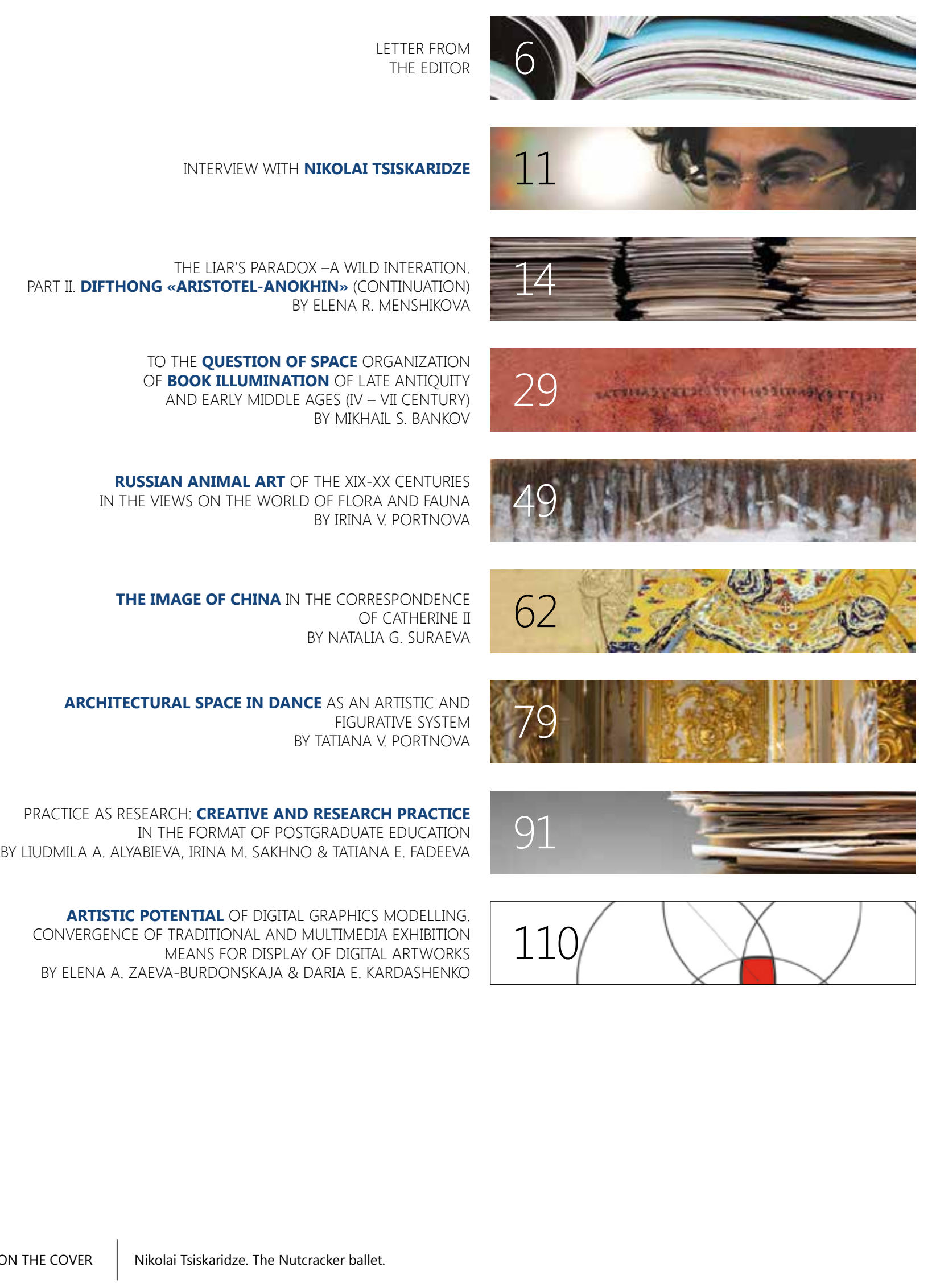


Редакционный совет:

Боулт Джон Эллис

(США)

Бурганов Александр Николаевич

Бурганова Мария Александровна

Гао Мэн

(Китай)

Гланц Томаш
(Германия)

Кравецкий Александр Геннадиевич

Койо Сано

(Япония)

Мислер Николетта

(Италия)

Пан Яочанг

(Китай)

Павлова Ирина Борисовна

(Россия)

Перельштейн Роман Максович

(Россия)

Плетнева Александра Андреевна

(Россия)

Почехина Елена

(Польша)

Пружинин Борис Исаевич

Рыжинский Александр Сергеевич

(Россия)

Сахно Ирина Михайловна

(Россия)

Смоленков Анатолий Петрович

(Россия)

Смоленкова Юлия Анатольевна

(Россия)

Танехиса Отабе

ивьян Юрий Гаврилович

(США)

Редактор

- доктор наук, профессор Университета Южной Калифорнии сздатель и директор Института современной русской культур

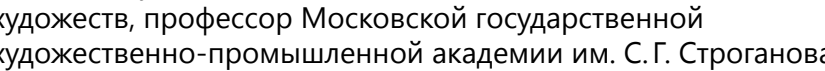

- доктор искусствоведения, профессор Московской им. С.Г. Строганова, академик Российской академии художест

- доктор наук, профессор, Guangzhou Academy of fine arts

- доктор, научный сотрудник Исследовательского центра Восточной Европы Бременского университета, профессор The Charles University (Чехия)

- кандидат филологических наук, ведущий научный сотрудник Института русского языка Российской академии наук

- nрофеccop, Toho Gakuyen University of Music

— професcop, Instituto Universitario Orientale, Naples

- профессор кафедры истории и теории искусства колледжа Академического комитета Шанхайского Университет - доктор филологических наук, старший научный сотрудник
Института мировой литературы РАН

- доктор искусствоведения, Всероссийский государственный институт кинематографии им. С.А. Герасимова

- кандидат филологических наук, научный сотрудник Института русского языка Российской академии наук

- доктор наук, профессор, University of Warmia and Mazury in

доктор философских наук, профессор, главный редактор журнала «Вопросы философии»

- доктор наук, профессор Российской академии музыки им. Гнесиных

- доктор филологии, профессор Российского университета Дружбы

- кандидат искусствоведения, профессор Московской осударственной художественно-промышленной академии им. С. Г. Строганова, академик Российской академии художеств

- кандидат искусствоведения, доцент Московской государственной художественно-промышленной академии им. С.Г. Строганова

- доктор наук, профессор, заведующий кафедры Эстетики и теории искусства Токийского университета Cinema and Media Studies, Art History, Slavic Languages and

Смоленкова Юлия Анатольевна (Россия)
НАУЧНО-АНАЛИТИЧЕСКИЙ

ЖУРНАЛ «ДОМ БУРГАНОВА.

№ 4

СЛОВО РЕДАКТОРА

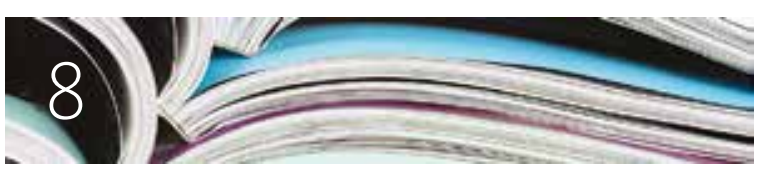

ИНТЕРВЬЮ С НИКОЛАЕМ ЦИСКАРИДЗ

ЕЛЕНА РУДОЛЬФОВНА МЕНЬШИКОВА НАСТ (ПРОДОЛЖЕНИЕ)
(ПЕЛ-АНОХИН,

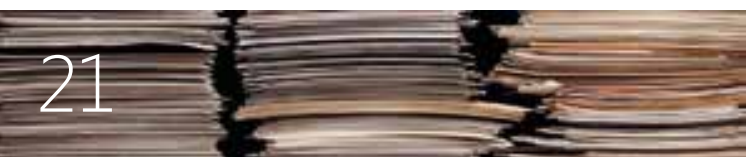

МИХАИЛ СЕРГЕЕВИЧ БАНКОВ: К ВОПРОСУ ОРГАНИЗАЦИИ ПРОСТРАНСТВА И РАННЕГО СРЕДНЕВЕКОВЬЯ ( IV-VII BB.)

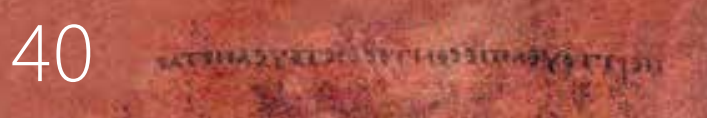

ИРИНА ВАСИЛЬЕВНА ПОРТНОВА: XIX-XX BEKOB

ВО ВЗГЛЯДАХ НА МИР ФЛОРЫ И ФАУНЫ

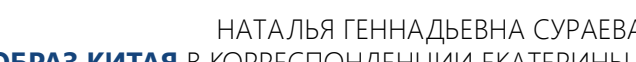

ТАТЬЯНА ВАСИЛЬЕВНА ПОРТНОВА АРХИТЕКТУРНОЕ ПРОСТРАНСТВО В ТАНL КАК ХУДОЖЕСТВЕННО-ОБРАЗНАЯ СИСТЕМА

ЛЮДМИЛА АНАТОЛЬЕВНА АЛЯБЬЕВА
ИРИНА МИХАЙЛОВНА САХНО, ТАТЬЯНА ЕВГЕНЬЕВА ФАДЕЕВА

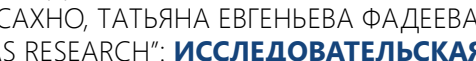
И TBOРЧЕСКАЯ ПРАКТИКА В ФОРМАТЕ ПОСТДИПЛОМНОГО ОБУЧЕНИЯ ЕЛЕНА АНАТОЛЬЕВНА ЗАЕВА-БУРДОНСКАЯ ХУДОЖЕСТВЕННЫЙ ПОТЕНЦИАЛ ГРАФИЧЕСКОГО ЦИФРОВОГО МОДЕЛИРОВАНИЯ. КОНВЕРГЕНЦИЯ ТРАДИЦИОННЫХ ДЕМОНСТРАЦИИ ПРОИЗВЕДЕНИЙ ЦИФРОВОГО ИСКУССТВА
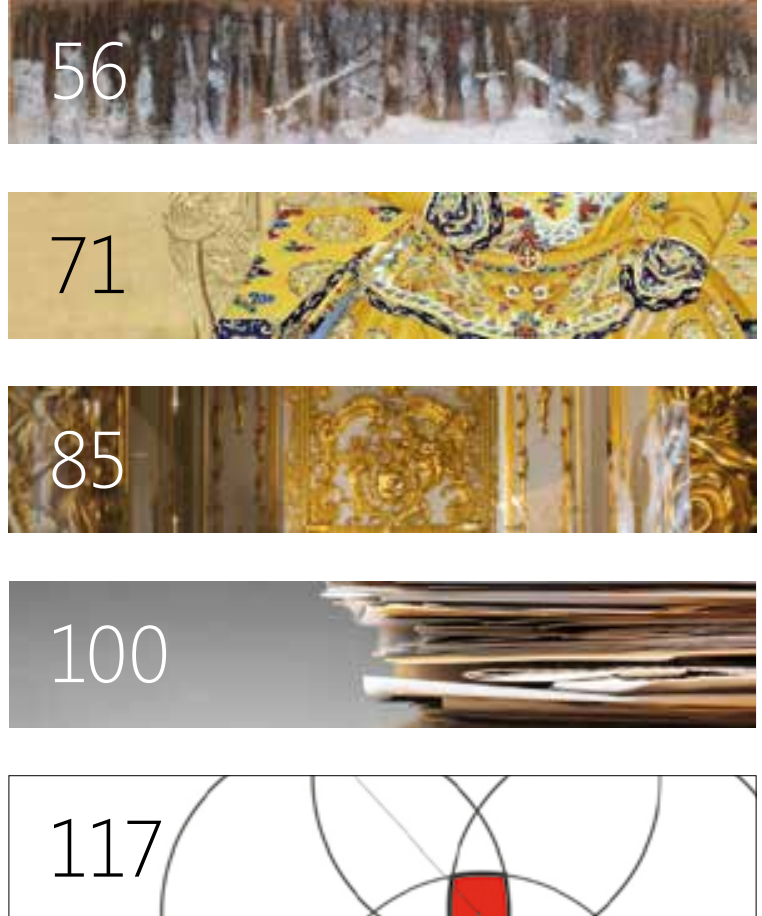
LETTER

FROM

THE EDITOR

Scientific and Analytical Journal Burganov House

Space of culture

\#4/2021
Dear readers,

We are pleased to present to you Issue 4, 2021, of the scientific and analytical journal Burganov House. The Space of Culture.

Upon the recommendation of the Expert Council of the Higher Attestation Commission, the journal is included in the List of Leading Peer-reviewed Scientific Journals and Publications in which the main scientific results of theses for the academic degrees of doctor and candidate of science must be published. The journal publishes scientific articles by lead-
The ing specialists in various humanitarian fields, doctoral students, and graduate students. Research areas concern topical problems in multiple areas of culture, art, philology, and linguistics. This versatility of the review reveals the main specificity of the journal, which represents the current state of the cultural space.

The journal traditionally opens with the Academic Interview rubric. In the issue, we present an outstanding figure of world culture - Nikolai Tsiskaridze, a Member of the Council for Culture and Art under the President of the Russian Federation People's Artist of Russia, Rector of the Vaganova Academy of Russian Ballet. His charismatic image Academy of Russian Ballet. His charism

personifies the Russian ballet school.
The article "The Liar's Paradox -a wild interation. Part II. Difthong "Aristotel-Anokhin" (continuation) by E.Menshikova develops the theme of the paradoxes of the modern space of culture. The author explores such concepts as consciousness as a "resexplores such concepts as consciousness as a "res-
onant system" and various types of thinking, comparing modernity with the ancient philosophical and cultural tradition.

In his article "On the Issue of Organising Space in Book Miniatures of Late Antiquity and the Early Middle Ages. 4th-7th Centuries", M.Bankov analyses polychrome miniature in the context of the book creation art. The author believes that the development of spatial constructions in miniature painting is an indivisible process in which each new stage is is an indivisible process in which
derived from the previous one.

The views of animal painters of the 19th-20th
the centuries on the world of wildlife, the factor of the relationship between man and nature, reflected in works of art, are considered by I.Portnova in the article "Russian Animalistic Art of the 19th-20th Centicle "Russian Animalistic Art of the 19th-20th Centuries in the Views on the World of Flora and Fauna".
The extensive correspondence of Empress Catherine II with politicians, scientists and cultural figures of Europe during the period of difficult relations between Russia and China is investigated by N.Suraeva in the article "The Image of China in the Correspondence of Catherine II". Particular emphasis is placed on the correspondence between Catherine II and Voltaire.

In the article "Architectural Space in Dance as an Artistic-figurative System", T.Portnova considers the expressive means of dance and architecture, analyses the general and the specific in their artistic language, reveals the degree of interaction of architectural principles with dance drama and choreographic composition.

In the article "Practice as Research: Creative and Research Practice in the Format of Postgraduate Education", the team of authors, L.Alyabyeva, I.Sakhno and T.Fadeeva, summarise the experience of European educational programs and, after their critical understanding, create the author's concept. The authors believe that practice and research have long been inseparable in educational programs in the field of contemporary art and design.

In the article "Artistic Potential of Graphic Digital Modelling. The Convergence of Traditional and Multimedia Exhibition Means in the Display of Digital Art Works", E.Zayeva-Burdonskaya and D.Kardashenko study the artistic potential of computer graphic modelling in the space of contemporary artistic creation and artistic exhibition systems. The authors provide examples of contemporary exhibitions that implement the complex convergence of traditional and multimedia exhibition means in the display of digital art works.

The publication is addressed to professionals specialising in the theory and practice of the fine arts and philology and all those interested in the arts and culture. 
Мы рады представить Вам № 4/2021 научно-аналитического журнала «Дом Бурганова. Пространство культуры».

По рекомендации Экспертного совета ВАК журнал включён в Перечень ведущих рецензируемых научных журналов и изданий, в которых должны быть опубликованы основные научные результаты диссертаций на соискание учёных степеней доктора и кандидата наук. учёных степеней доктора и кандидата наук.
В журнале публикуются научные статьи ведущих специалистов разных гуманитарных областей докторантов и аспирантов. Направления исследований касаются актуальных проблем в различных областях культуры, искусства, филологии и языкознания. В этой многогранности обозрения проявилась основная специфика журнала, представляющего современное состояние пространства культуры.

Журнал традиционно открывает «Академическое интервью». В этом номере мы представляем члена Совета по культуре и искусству при Пре зиденте РФ, Народного артиста России, ректора Академии русского балета имени Вагановой, выдающегося деятеля мировой культуры - Николая Максимовича Цискаридзе. Его харизматический образ олицетворяет русскую балетную школу.

Е.Р. Меньшикова в статье «Парадокс лгуна - невероятное повторение. Часть II. "Дифтонг Аристотель-Анохин" (продолжение)», развивает тему парадоксов современного пространства культуры. Автор исследует такие понятия, как Сознание, в качестве «резонансной системы» и различные типы мышления, сравнивая современность с античной философской и культурной традицией.

М.С. Банков в статье «К вопросу организации пространства в книжной миниатюре поздней Античности и раннего Средневековья (IV-VII вв.) исследует полихромную миниатюру в контексте искусства создания книги. Автор полагает, что развитие пространственных построений в миниатюрной живописи представляет собой целостный процесс, в котором каждый новый этап вытекает из предыдущего.

Взгляды художников-анималистов XIX-XX веков на мир живой природы, фактор взаимосвязи человека и природы, отражённые в произведениях искусства, рассматривает И.В. Портнова в статье «Русское анималистическое искусство XIXXX веков во взглядах на мир флоры и фауны».
Обширную переписку императрицы Екатерины II с политиками, деятелями науки и культуры Европы в период сложных отношений между Россией и Китаем исследует Н.Г. Сураева в статье «Образ Китая в корреспонденции Екатерины II». Особый акцент делается на переписке Екатерины II с Вольтером.

В статье «Архитектурное пространство в танце как художественно-образная система» Т.В. Портнова рассматривает выразительные средства танца и архитектуры, анализирует общее и специфическое в природе их художественного языка, выявляет степень взаимодействия архитектурных принципов с танцевальной драматургией и хореографической композицией.

Коллектив авторов - Л.А. Алябьева, И.М. Сах но и Т.Е. Фадеева в статье «"Practice as Research". исследовательская и творческая практика в формате постдипломного обучения» обобщают опыт европейских образовательных программ и после их критического осмысления создают автор скую концепцию. Авторы полагают, что практика и исследование давно неразделимы в образовательных программах в области современного искусства и дизайна.

Е.А. Заева-Бурдонская и Д. Кардашенко в статье «Художественный потенциал графического цифрового моделирования. Конвергенция традиционных и мультимедийных выставочных средств в демонстрации произведений цифрового искус ства» рассматривают художественный потенци ал компьютерного графического моделирования в пространстве современного художественного творчества и художественных систем экспонирования. Авторы приводят примеры современных выставок, которые реализуют сложную конвергенцию традиционных и мультимедийных экспо зиционных средств в демонстрации произведений цифрового искусства.

Издание адресовано профессионалам, специализирующимся в области теории и практики изобразительного искусства и филологии, а также всем, кто интересуется вопросами искусства и культуры. 


\section{INTERVIEW WITH NIKOLAI TSISKARIDZE - \\ A MEMBER OF THE COUNCIL FOR CULTURE AND ART UNDER THE PRESIDENT OF THE RUSSIAN FEDERATION, RECTOR OF THE VAGANOVA ACADEMY OF RUSSIAN BALLET}

\section{DOI: 10.36340/2071-6818-2021-17-4-10-13}

Traditionally, our journal opens with an academic interview. In this issue, we present an outstanding figure of world culture - Nikolai Tsiskaridze, a member of the Council for Culture and Art under the President of the Russian Federation National Artist of Russia, Rector of the Vaganova Academy of Russian Ballet. His charismatic image personifies the Russian ballet school.

It is universally recognised that Tsiskaridze's creative and pedagogical activity has given a new impetus to the school of classical dance. Thanks to his efforts, the Vaganova Academy of Russian Ballet has rightfully taken a leading place on the world stage and is highly regarded by the professional community.

Nikolai Tsiskaridze kindly agreed to answer the questions of Maria Burganova, the Editor-in-Chief of the journal Burganov House. Space of Culture.
Maria A. Burganova: What defines contemporary culture in Russia? Dialogue with the past, search for innovations, an expectation of change?

Nikolai M. Tsiskaridze: Everything listed by you. And also, the rapid development of the culture of consumerism.

M.B.: Are culture and the state interrelated concepts? To what extent does the state determine the development of culture? Can culture exist without government support?

N.Ts.: At all times, culture could not exist without state support; therefore, of course, these concepts are interrelated.

M.B.: The cultural space is a dialogue space. The audience creates it jointly with an artist, an actor, a musician. Today it seems that the viewer comes to the theatre, museum, philharmonic "to have a rest". Who is an ideal viewer? What would you like to communicate to them? To what extent does the creative process take the possible reaction of the viewer into account?

N.Ts.: There can be no dialogue. There is an artist, and there is the viewer's perception of them. Any cultural space - theatre, museum, and so on, has always been a space for relaxation. When they say that the viewer also "works", "creates" - it is nonsense.

M.B.: The modern cultural space is permeated with Internet culture. How does this relate to classical heritage and education? Has a new cultural myth been formed?

N.Ts.: The Internet is just a form of expression

M. B. Virtuality is fully capturing museums and theatres. Exhibitions based on media technologies have become commonplace. In theatres, laptops broadcast ing monologues and stage performances appear in-

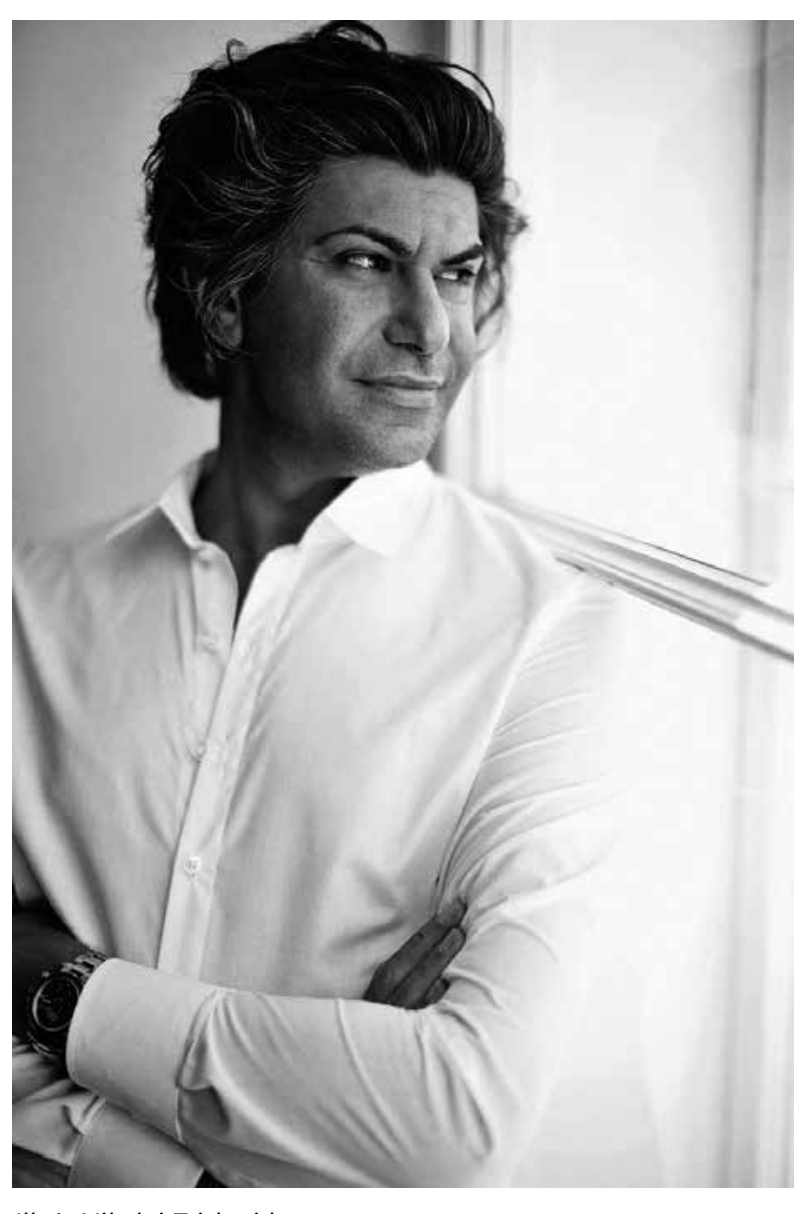

IIl. 1. Nikolai Tsiskaridze

stead of actors. Is this a farce or a new reality in art? Is there a border in the cultural space which virtual technologies cannot cross?

N.Ts.: Some people like butter, and some like margarine. If a person loves margarine, then they will use it If someone wants to use a laptop, they will use a laptop. Whoever wants to see an artist will come to the artist. 


\section{ИНТЕРВЬЮ С НИКОЛАЕМ ЦИСКАРИДЗЕ - РЕКТОРОМ АКАДЕМИИ РУССКОГО БАЛЕТА \\ ИМЕНИ ВАГАНОВОЙ, ЧЛЕНОМ СОВЕТА}

\section{ПО КУЛЬТУРЕ И ИСКУССТВУ ПРИ ПРЕЗИДЕНТЕ РФ}

\section{DOI: 1036340/2071-6818-2021-17-4-10-13}

Традиционно наш журнал открывает академическое интервью. В этом номере мы представляем Члена Совета по культуре и искусству при Президенте РФ, Народного артиста России, ректора Академии русского балета имени Вагановой, выдающегося деятеля мировой культуры Николая Максимовича Цискаридзе. Его харизматический образ олицетворяет русскую балетную иколу.

Творческая и педагогическая деятельность Н. Цискаридзе по всеобщему признанию дали новый импульс иколе классического танца. Благодаря его усилиям Академия русского балета имени Вагановой по праву заняла ведущее место на мировой сиене и высоко ченится профессиональным сообществом. Николай Максимович Цискаридзе любезно согласился ответить на опросы главного редактора журнала «Дом Бурганова. Пространстео культуры» Марии А. Бургановой.
Мария А. Бурганова: Николай Максимович, что, на Ваш взгляд, определяет современную культуры в России? Диалог с прошлым, поиски новаций, ожидание перемен?

Николай М. Цискаридзе: Все, перечисленное Вами. И еще - бурное развитие культуры потребительства.

М.Б.: Культура и Государство - понятия взаимосвязанные? В какой мере государство определяет развитие культуры? Может ли культура существовать без государственной поддержки?

н.ц. Во все времена культура не могла суце ствовать без государственной поддержки, поэтому, разумеется, это понятия взаимосвязанные.

М.Б.: Пространство культуры-это диа логовое пространство. Его создают совместно с художником, актёром, музыкантом также и зрители. Сегодня создаётся впечатление, что зритель приходит в театр, музей, филармонию «отдохнуть». Каков идеальный зритель? Что бы Вы хотели ему транслировать? Насколько в креативном прочессе учитывается возможная реакция зрителя?

Н.Ц.: Никакого диалога быть не может. Есть художник и его восприятие зрителем. И всегда любое культурное пространство — театр, музей и т. - было пространством для отдыха. Когд говорят, что зритель тоже «работает», «творит»это чушь.

М.Б.: Современное культурное пространство пронизано интернет-культурой. Наскольи образованием? Сформирован ли новый культурный миф?

Н.Ц.: Интернет - всего лишь форма выражения.

М.Б.: Виртуальность в полной мере захва тывает музеи и театры. Выставки на основе медиа-технологий стали повседневностью. В театре вместо актёров появляются ноут буки, транслирующие монологи и сценические действа. Это фарс или новая реальность в искусстве? Есть ли граница в пространстве культуры, за которую виртуальным технологиям нельзя заступать?

Н.Ц.: Кто-то любит масло, а кто-то маргарин. Если человек любит маргарин, значит он будет его употреблять. Если кому-то хочется смотреть видеть артиста, дойдет до артиста.

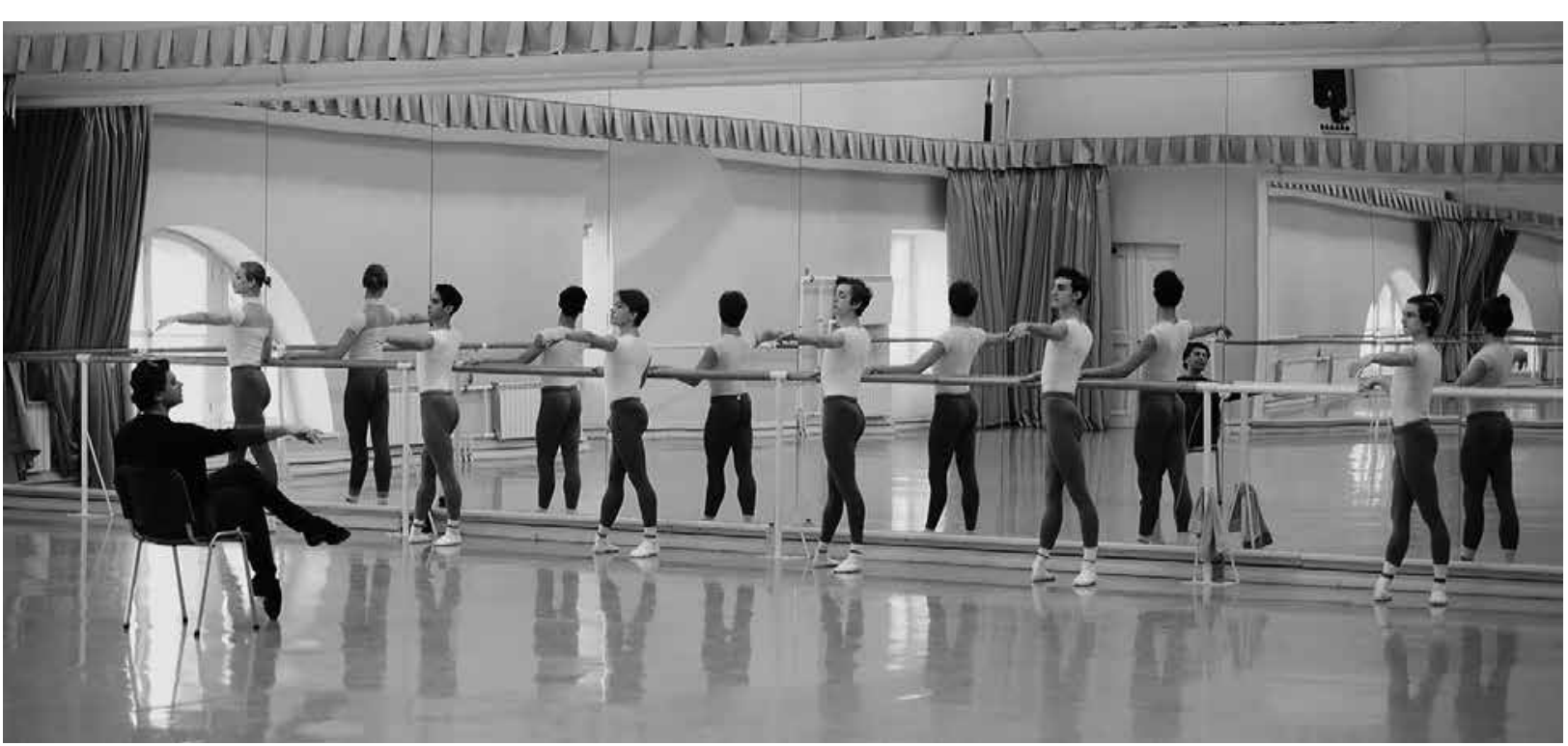

IIl. 2. Nikolai Tsiskaridze teaching a class at Vaganova Ballet Academy. February 2019.

Photo OVaganova Ballet Academy 
Elena R. Menshikova

Candidate of Cultural Studies

Expert New Institute for Cultural Research

e-mail.com: elen_menshikova@mail.ru

Moscow, Russia

OCRID 0000-0002-5738-0732

DOI: 10.36340/2071-6818-2021-17-4-14-28

\section{THE LIAR'S PARADOX -A WILD INTERATION. PART II. DIFTHONG «ARISTOTEL-ANOKHIN»}

\section{(CONTINUATION)}

Summary: There are more and more precedents with offended infants of 30-40 years old - they are not emotionally abstinent, because they are in an artificial com of infantilism, in which 'desire' has replaced 'sacrifice', of infantilism, in which 'desire has replaced 'sacrifice, and are clearly hypocritical, which is why the Holiday of Disobedience, hanging around the planet with a blinking which the bifurcation points are taken out - beyond the or it of common understanding turning Consciousness the the quietest Sphinx, producing hypotheses. The saying, willingly or unwittingly, can becomot a "winged miscill willingly or unwittingly, can become a "winged mis" - and destroy the wholew weod or bad, but the theory created by the presentinent of scientific reine plan but on one condition: while maintaining peace and the but on one condition. While maintaining peace ty the will or Consciousness - the indispensable parias para sanding. Thus, a hypothesis based on a para ux forms

My 'perception' (of an essential philosopher) at the beginning of the 20th year of the 21st century as a "response" to the perception of the world ry as a "response" to the perception of the world stability of being, behavioral reaction and mental reflections) by Aristotle (384/383 - $322 \mathrm{BC}$ ) Chalkidiki), an ancient philosopher-encyclopedist, turned out to be closer and "dearer" to me, a distant foreigner in time and space, than the perception of a world-renowned scientist, neurophysiologist, prof Anokhin K. V. (born 1957, Moscow), a researche of seemingly the same fundamental problems of science: human consciousness. My contemporary and compatriot, moreover, a colleague in the wide field of «ontological knowledge», turned out to be an opponent of Aristotle himself, and worse - the Image of the Concept, and thereby builds a fundamental frame of the worldview, without belittling the elephants, and without forgetting the whale. In our world aliar as Caesar's wife turns out to be beyond suspicion, and, therefore, discussion, and his figure is so transparen and, therefore, discussion, and his figure is so transparen and nano-technological that it has long been soldered the pillars of thinking, which is why not only looms as wise turtle, but is also perceived by a cheerful Buddh From time to time the whale opens its mouth we all find ourselves in its throat, and the liar hims is outside the Law, outside the conflict, but in the Law: in the logal field of the Absolute, who knows the Law: is ness is accustomed.

Keywords: Consciousness, liar's paradox, Image of conept, singularity, 'multiple unity' Meaning, violence, continuum, dichotomy, hypocrisy, capture as a formality.

reasoner. Drawing on the statements of scientists (archaic time and modern), taken from open sources, the author provided the reader with the opportunity to draw a conclusion himself, that is, to add up his own «understanding» of "perception» and the «movement of thought» of a person who is able to form and format «thinking» and 'understanding', and most importantly, to notice how much Consciousness is engaged (and by whom it is recruited), or is the result of the painstaking and honest work of the mind / intellect of the speaker (writer). ${ }^{1}$ The clarification introduced at the request of the editors, according to the author, only exacerbates the problem of the "liar's paradox": the essential problem of 1. The clarification introduced at July 31,2021 , the same material itself was written at February 2020 the toothless sperm whale that substituted its back for
Deception and the "problem of lies in science", and does not interfere with Eidos, but adds sadness to our "understanding". We continue the interrupted thread of our reasoning.

\section{VITAL CONTINUUM}

If you explore the space of the "being of culture" in all the "madness" of its harmonious inflorescences, then you need "your own" special mental language, which will braid and stretch the ribbons of representations, tighten with the associative knot of perception, convey (precisely, capaciously) "contemplative feeling", which will reveal a "conceivable" (already meaningful) perception of what is "here and now", since for each of us there is no other world (in its organic form) and will not be. My experience is being formed 'now', but its fixation occurs by "perception" and is placed in a box of "memory" already meaningful - that is, Consciousness first examines ("feels"), and, understanding, straining the neural manes of eidos, the perceived itself, running past you, sometimes laughing, sometimes knocking out of the saddle, sometimes lifting from his knees, suddenly embracing, he begins to put the mirror fragments of 'mental images' into 'funny pictures', and, absorbing it entirely, confidently directs towards the goal - the center of 'myself'.

The term "continuum" - "Latin infinity", in our steadfast glance, is more suitable for Consciousness than for Anokhin's "cognition", since it is older in origin and closer in meaning: "united in itself. continuing without interruption, continuous, uninterrupted, incessant ${ }^{\prime 2}$. This is a loan translation from the Latin adjective, whose denotation directly depends on the manifested properties of a particular object (signs and manifestations), means "human brain", which is "a continuous material environment, the properties of which change continuously in space" 3 which represents "the totality of all mental operations: changing and fast-flowing". The philosophical dictionary could not get around it as a "Sisyphean stone": "Continuum (Latin continuum 'continuous') is a term used in mathematics, natura

2. Continuus, a, um - directly connecting: 1) in space, a) with another object (about one, two or more) connected, immediately adjacent, immediately adjoined, communicating, ing, uninterrupted, unbreakable; 2) in time, a) with another subject (about one, two or more) immediately following one after the other, b) connected in itself, continuing with out interruption, continuous, uninterrupted, incessant, oppugnatio: incommoda (Latin-Russian dictionary. / O. A. Pemo, 2017. P. 143)

Dictionary of foreign words. Decree. ed. P. 249 science and philosophy. In mathematics, K. is understood as infinite sets that are quantitatively equivalent to the set of real numbers ... <in> physics is understood as an idealized model of a single physical space-time. In accordance with the concepts of the general theory of relativity, the metric structure of the space-time continuum is determined by the distribution of the density of matter and radiation in the Universe" 4 . Carefully reading the Latin dictionary, you can find, among other expansive connotations, and the following: "oppugnatio" - 'attack', 'assault', 'onslaught', 'strike', and all together 'siege art'. The supplement reveals an example of "enviable constancy" that the mental memory captures and reflects the language - it is enough to look around oneself meaningfully: in time and space, it turns out that this "siege art" seemed to dissolve in the "culture of being": it got stronger and improved, mutated in various forms, like a virus, for it manifests its virulence by the instability of society, the psychological instability of its citizens, the international instability of the planet, the vain - not harmonious - existence of which is demonstrated precisely by the 'unfinished, permanent process' of "constant reorganization." As the author of the concept of "Trojan terrorism", whose roots I see, first of all, in the method of "Caesar's violence", I can only conclude that this 'endless process of violence' is only improving: the world is growing by curse.

But if we take into account that 'continuity' is a necessary 'condition for development' - common for nature and man, and therefore for Consciousness (we emphasize that the subject of our interest is man), and if we remember that the Greek word entelechy' ( $\boldsymbol{\varepsilon} \boldsymbol{\delta} \boldsymbol{\varepsilon} \boldsymbol{\varepsilon} \boldsymbol{\varepsilon} \boldsymbol{x} \boldsymbol{\eta} \boldsymbol{\zeta}$ - 'continuous', 'eternal') determined the essence of philosophical views: the protoplasm of scientific and theoretical thinking, its nuclear charge is the driving force that makes the Idea (goal) come true, materializing, possessing irresistible ${ }^{5}$ impetuosity towards development (life principle), moving towards achievement, starting from natural-philosophical concepts to scholastic 4. See: "The concept of $K$. as one of the refinements of the category of continuity has important methodological functions. ical status ("nature does not make leaps") and is a necessary condition for the truth of the laws of nature (and S.'s work). Within the framework of dialectical-materialistic research, the concept of $K$. is used to analyze the principle of causality, the relationship between part and the whole, discontinuous and continuous, finite and infinite" (Philosophical Encyclopedic "Achilles' unrestrained hands" is a constant epithet of Hom- 
times up to Hegel, then the necessary transgression is observed with the naked eye or, as others would have noted, signs of convergence ${ }^{6}$ are obvious, and therefore we will pay some attention to the Greek hypostasis of this "vital continuity".

The philosophical dictionary has another meaning: "Entelechy (Greek $\varepsilon \vee \tau \varepsilon \lambda \varepsilon \chi \varepsilon ı \alpha$, from $\varepsilon \vee \tau \varepsilon \lambda \eta \sigma$ - finished, completed and $\varepsilon \chi \omega-I$ have, I am in a state; actually - being-in-a-state-of-complete fulfillment, fulfillment), one of the two terms of Aristotle's philosophy (along with energy) to denote the actual reality of an object, an act, as opposed to its potency, possibility" ${ }^{\prime \prime}$. And one more thing: "Entelechy (Greek - completion, fulfillment) - in the philosophy of Aristotle: a way of being a thing the essence of which is fully realized, a form that is realized in matter; an active principle that transforms a possibility into reality, actuality and thus an exhaustive possibility or potentiality" ${ }^{8}$. Meanwhile, if we turn directly to the Greek language, in which the philosophy of Aristotle was woven, then the definition will be more than laconic - it will be discouraging in its opposite essence: "contin uous, constant". Philosophical dictionary entry relies on a word that is not in the Greek dictionary - $\varepsilon \vee \tau \varepsilon \lambda \varepsilon \times \eta\llcorner\alpha$, but there is a word - $\mathbf{\varepsilon v - \tau \varepsilon \lambda \eta \eta ~}$ ('perfect', 'perfect', 'excellent', 'full'), and there is a word - $-\varepsilon v \delta \varepsilon \lambda \varepsilon \times \eta \zeta$ ('continuous', 'continuous') The truth in this case is not just in the middle it is in another word - Greek $\boldsymbol{\varepsilon v}-\boldsymbol{\delta} \varepsilon \boldsymbol{\lambda} \boldsymbol{\varepsilon} \mathbf{n} \boldsymbol{\eta}$, which means "continuity and constant duration, flowing continuously". The Greek script reveals the difference in meanings. Isn't it similar to the Heraclitean: "everything flows and everything changes"? As if the very irrepressibility of the world echoes the human $\varepsilon \vee \delta \varepsilon \lambda \varepsilon \chi \varepsilon i \alpha$, or vice versa, which is more natural, it was a 'cast' - the human brain is arranged very complexly, and as a complex "bio-matrix" it conceals in itself no less than the universe itsel but works at best for one-tenth of its capabilities. So, two different substances surfaced: "continuous" and "finished".

6. "Convergence (lat. converge - approaching, converging) tities." "Linguistic Encyclopedic Dictionary. - M.: Soviet encyclopedia, 1990. P. 234].

Philosophical Encyclopedic Dictionary. - M.: Sov. Encyclopedia, 1983. P. 800

Philosophy: an encyclopedic dictionary / ed. A. A. Ivin. - M

Gardariki, 2006. P. 1014

thor's edition, 1899. P. 442, P. 432 .
Where has the original interpretation of the word gone, along with its continuity, flow, impetuosity, incompleteness, lasting and unable to stop? Only death of the organism) does the run-up of your $\varepsilon V \tau \varepsilon \lambda \varepsilon \chi \eta \zeta$ stop, since it is it that the mind turns on having received an impulse by the fact of its birth

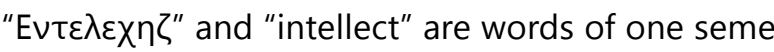
the meaning of which is clearly defined in the Greek dictionary - "continuous", "constant", and our own experience and the experience of others ("experience son of difficult mistakes" (Pushkin) ): the brain doe not know how to sleep, at best this is what we call "sleep mode": even during a short sleep, our brain compares pictures, and then gives us insight - daring insight, which makes you open your eyes, and prompting you to take action, requires the implementation of the "shown" in a visible image or verbal mental "sound" (pictures, often colored, words, often ready-made phrases and rhymes). And the very word "intellect" ("the mental ability of a person") does not in any way imply his own death, be cause his "finitude" and "completeness" is possible only when the "light bulb is off", and it can only be guaranteed by death, which phenomenally stops the phenomenally arranged the apparatus of the brain that performs mental operations, sending impulses to certain zones of the brain centers - the very "galaxy weighing a little over a kilogram" that even "g a dream continues to "create" and "breathe", otherwise: "flow and continuously move".

Alive, invincible $\varepsilon \vee \delta \varepsilon \lambda \varepsilon x \eta \zeta$, the flow of which is torn only by stopping the entire biological rhythm of the body (by heart death, or by force), cannot in any way be divided into logical or illogical phrases, its potentials are inexhaustible, it is not feasible in its entirety , since its "bottom" (limit, scale, volume) is not determined, and it cannot be said that its "essence is realized" to the end, because there can be many predetermined tasks, and as long as the brain in which it lives is alive, not energetically de-energized (life current), and thus ensuring its work, - the goldfish Ev $\delta \varepsilon \lambda \varepsilon \times \eta \zeta$ will tremble and swim. Aristotle in "Persuasion" insisted on the constant movement of a person towards happiness for harmony, for the consonance of the modes of "I" and "the world", which is possible only with well-functioning "entelechy", because therefore it is necessary "to turn to philosophy, if we are going to

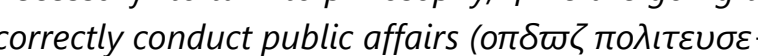

$\sigma \delta \alpha \iota)$ and usefully live your life (tov عavtwv $\beta$ เov $\delta$ $\alpha \xi \varepsilon l \nu \omega \phi \varepsilon \lambda(\mu \omega \zeta)^{\prime \prime} 10$. Otherwise, to be ready and involved in freedom of thought, or to own political reflection in the volume of alternating current of life. ${ }^{1}$

So, the continuum is vital continuity, it is en telechy, and we believe that when describing (speculative, of course) it is more appropriate / more accurate to use these 'names', because the denotation reflects both the essence of the phenomenon of Consciousness, and its causality and a necessary condition, since «to tie meanings into end less knots» - an occupation similar to weaving net and manifests not only <itself $\mathrm{f}$ as a "net of networks", like a fashion model, - the podium is exactly what is inside, and the shows themselves are possible only indirectly - through objects / products of your Consciousness (any embodiment, but material em bodiment), and "presentation" itself is not part of its immediate duties - it is rather an auxiliary function but it is important for Consciousness to save and maintain the continuity of purposeful movements of thought, which arise as a result of sensory perceptions going through the process of speculation online - then is "here and now", as Aristotle put it, in the immediately given time - and it creates itself (which is important it and more valuable) that "life principle", which is a life-giving force and pushes itself continuously, moreover, does not stop, does not hang in calculations, without restraining itself in mental intentions, - perceives, continuously connecting and bringing together impressions and reflections, comprehending - as if embracing, preserving, thought, but at the same time does not get tired of analyzing, controlling, making comprehension, throwing and directing the object / subject of perception to another plane, moving it in spacetime. The key here: "non-stop adherence to others" - convergence and transgression - interpenetration and interweaving, and not only touch, here is the interaction of your own different and all sensory perceptions-entelechies - "directly connect"immediately adjacent", "communicating",

10. Aristotelis fragmenta selecta / Recognovit W. D. Ross. Oxford, 1955. Quotes are from the Russian translation. AristoPer. in rus. E. V. Alymova - $\mathrm{SPb}$. Publishing house of St. Petersburg University. 2004. P. 25

11. Menshikova E. R. The Natural landscape of philosophy (in 2 parts). // House of Burganov. SPACE OF CULTURE, 4.2019, pp. published earlier: Menshikova ER. The Natural tandsca was Philosophy (The Political Reflection of Heraclitus and Aristotle). // Philosophy Study, V. 8, N. 1, 2018 'continuing incessantly, relentlessly' - in space time with others who are just as quick to ascend take off and land, perceptions-reflections of Others - different and other - this creates an endless continuum of your Consciousness and life itself in all its bottomless hyper-immodesty towards oneself - vitality, sensitive intelligible.

All this neurophysiologist Anokhin dubbed "in stone" (see above), in his opinion, all this "descriptive nonsense" (philosophy) is not needed in the study of Consciousness, but at the same time he "invented" the word (and, in our opinion, tore off the frog's legs: cogito - lat. 'to think', 'to suppose' - with the usual movement for a biologist - dismembered) in order to abandon the main thing the search for "causality", that is, Sense - this main purpose of Knowledge. What for? - an equally important question, among others, that a person poses before himself, cognizing the world. Instead, we have been offered (and now it seems, they are already talking about the state support program) model not of "understanding the world" — but sparkling model of "cognitive experience" that "will reconcile the brain and psyche, solve in one ... in one fell swoop the "damned" psychophysiological prob lem" (see interview above). That is, there are still reasons, but this is not a task, damn it! And in order to remove the "spell", we are invited to coun all the cogs and, having laid them out in bottles, with colored tags, indulging in memories, because individual experience "lives" there - in the past while forgetting about the present - vain and so stupidly unnecessary, for which you should prepare for a difficult and painstaking work, because you will have to count kogi while worms and fish then mice and macaques, and whether it will come to a person - no one knows - the hypernet is silent, does not give an answer. Of course, he will be silent, since the worm will definitely not see the "damned psychophysiological problem" of a person - the scale is different: where is he? and where is the curse? and most importantly: what is it for the worm? And while the professor, examining the brain of the mouse with a current, causes a 'background of experience' literally: collecting 'individual' 'prototypes' of mouse cogs, comprehending - no, adding the obtained samples into the totality of all 'mental operations of the mouse', that is, before it will respect in pose from electrical stimulation, there is a possibility that the "spell" will be removed, and first of all from the thought process, 
but the person himself (we hope so). If the "Cognitoma" program is aimed at studying Consciousness (of a human, we suppose?), Then why collect the experience of mice? The sensitive-tactile shock of a rat will not explain the process of inspiration in humans, even by the serial number of the cog

Unexpectedly for humans, in our unstable everyday life at the beginning of the 3rd millennium, the urgent request for the 'Superman' was replaced by the merger of two moons - competition and globalism, which caused a new wave of the hesychasm variety - "a silent immersion in the nervous activity of primitives and rodents". Apparently the time has come for the 'redemptive sacrifice' - for all sins against earthly and amphibious creatures, al creeping and sea creatures - the man himself, a worthless creature, useless (even for research, but maybe for the Kunstkamera), the word "damned" and unnecessary? Who will undertake to determine the degree of "need" of a person? His "humanity"? Its importance? I dare to ask: since the researcher is a human, then his "understanding" will be "human" (from the point of view of a human), and the mouse will experience the same feelings and emotions, will the same images arise / scare / discourage it as the experimenter? Anthropocentrism will not prevent, together with the tears of the mouse to calculate the coefficient of ethereal efforts of nonsense? When 'explaining' and 'understanding' it is more important, it seems to me, to preserve the terminological arsenal that has been accumulated over the centuries, and not to produce essences of lexical disorder, even if they tend to collect a multitude, which are secondary, because they are tautological. Emotions (including mental) are different fo everyone: in strength, brightness, speed, color rendering, share, reason, expression of will, direction presentation) and they all affect those sensory perceptions, which are then woven into "comprehen sion" and "understanding". We can say that these are 'segments of a worm', that terra will be delivered to you - a grain of "representation" as a tangible lump - with a chamomile, or edelweiss, but already "processed" by comprehension, that is, speculative perception.

Poetry, drawing, composing music - all this strengthens not just the work of the brain, but, by training, keeps the "muscles" of Consciousness in good shape: perception, representation, comprehension, imagination - thus obliging the body to produce independently the necessary 'endorphin', and in sufficient quantity for a specific person, creating conditions for a harmonious existence, and at the same time preparing the outline of its astructurality. life does not consist of one questioning - you still need to create - each / everyone - and without this life is an empty and indifferent sound, mournful like a fallen leaf, and therefore, paving the way for a new one, I repeat my definition: Conscious ness is 'self-organizing Chaos' that acts as a "resonant system" in the structure of "dissipative Being", giving rise to eidos of perception and hiding quanta of Sense in art, producing an "enzyme of resistance" to "being-in-the-world", and therefore it is also the "art of resistance".

And you need and can resist in different ways, it is important to notice the "binary code" behind which the cynical formal mind is hidden, forgetting that "transparency" is helpful and insidious. And you just need to know: the one who operates with "formal reason", using and resorting to the "paradox of a liar": formalizing literally grammatically and stylistically, that is, linguistic stereotypes of public belief, like Caesar's violence, parasitizing on the "binary premise" that spreads a carpet of hypocrisy, ready to tighten the lasso, carries out a formal seizure -

Bak of the 'double bottom' - by Deception.

Bakhtin and Bulgakov argued about Lie - "The Rhetorical Lady", Freudenberg reflected, Kharms noticed it in the "bloody underwear", Krzhizhanovsky and Shostakovich searched for and found forms of its reflection in art (practically simultaneously - in the 1920s), building his doubts around the "clown" who was a "liar" in the highest sense - like a "priest of an allegory", but who turned out to be a "rascal", and from a practical point of view, this did not allow "contradiction": since he was familiar with the "nooks" of being, the essence of the universe is known: life is in life itself, which means that in the depths of the world there is always a way out of "non-being", but there is also a corner for self-interest, which only contributes to life itself (organic). much does it cost to panic a "stimulated" mouse? And a man? At the time of the shelling? And what about the panic when a deception is discovered? If your own experience is not enough, then you can be curious about the "last year's snow", under which you will find someone's "escaped perception".

And how is such a face, slipped by meaning a replica-cry of Ivan Bunin: "There are so many lies that you can suffocate. All friends, all acquaintanc es, whom I would never have dared to think of as liars, are now lying at every step. Not a single soul can help but lie, can not help adding its own lie, its distortion to the knowingly false rumor. And all this is from an intolerable thirst for it to be the way one desires intolerably" [2, p. 59], and which the writer of subtle nervous giftedness accompanies with an explanation of the soothsayer - an insight of amazing accuracy: "This is the secret of the Bolsheviks - to kill susceptibility. People live by measure, and their sensitivity and imagination are measured by them - step over the measure. These are like prices for bread, for beef. "What? Three ruble pounds !? " And appoint a thousand - and end to amazement, screaming, tetanus, insensitivity. "How? Seven hanged!?" - "No, dear, not seven, but seven hundred! - And here certainly tetanus - you can still imagine seven hanging, but try seven hundred even seventy!" [2, p. 67]. Kill Susceptibility! We believe that this is the loss of the 'inner vision': the ability to perceive the 'monstrous' as 'monstrous', which led to a clouding of reason, general insanity, was the cause of lexical impoverishment, or human "languagelessness," with an unbridled craving for violence. As if they scratched the 'imagination' with a knife, born of the ahs of childhood and the curiosity of youth, which they filled with winged images, awakening the Images of concepts, and with them the meanings - direct, unambiguous, double-valued, polysemantic - clear and reasonable, and with it the ability to think independently, - and as if there was a darkening in the lens of the eye - not to distinguish the scoundrel-liar. And this allowed the archaic hybrid to the anarchic boor - a riotous, brave, wild, shameless cynic, allowed to destroy the world, allowing the International Lies to reign in Russia rather quickly, and spread out there with a thin gauntlet. Loss of "visual acuity" is always possible with strong mental overload, which is as sociated with the tension of the optic nerve, but the First World War became such a colossal "overstrain" for Russia that it dragged on for four years and led the "exhaustion of Consciousness" to the Russian nation to degradation - a state of devastated thinking. Then everything was restored - not immediately and not for a long time, but that's another story - about her later.

Since my own perception of the Lie at the time when the dissertation was conceived and written was not so 'catastrophic', the noted (even then) Bunin's quote from "Cursed Days" (which was published in
Russia only in 1990) simply remained as a "quote", and only now I felt the heat of "escaped perception" in it, and what became so important to me as the 'argument of a contemporary' (if not one temporal, then one spatial cultural parallel), who saw the cause of the social catastrophe precisely in Lies. We agree with the writer and continue: the 'loss of receptivity', about which the director K. Muratova spoke with each of her films, crying out, seeking justice, portraying 'asthenic syndrome' as 'asthenic Consciousness that lies': constantly, from time to time, cunning, distorting, sneering, mocking, hypocrisy - and thus changing the balance of perception: the excessiveness of petty, personal, private Deception. As a 'trick' - part of someone else's game, this forcibly and forgedly acquired 'immunity', invading the 'mental digestion system', accustomed to 'double sendings' like chips that canno be 'fed', but hunger can be 'deceived' — so gradually replaced the entire "diet" of Consciousness (and modern realities are proof of this - a universal misfortune), and so cultivated a "lack of understanding" which turned out to be a virus of a conflict, obvious by "blindness" and cruel in flattery and indifference.

Why is "violence" so inevitable? — is completion possible? This is the "problem of Consciousness", which for the Consciousness itself remains insoluble for now. However, it is precisely the "passion for violence" that reveals the modern profanation of scientific knowledge, driven into the modern framework of "digital optimization", but also Knowledge in general, which turned out to be slandered and defamed by Ignorance. And therefore, as we think the problem, as always, is on the surface - it is in the oppression of "character". And here the "experience of mental sketches" Theocritus can serve as certain medicine and help. Let us note from ourselves, the Cynic (he is a hybrid) appears only on the wave of "cynicism" - there is a lot of nihilism with ignorance, and only with the spear of hybridism - the mockery and onslaught of the ignorant, his aggressive lie. At the same time, the liar's paradox is the "law of the excluded third", or the lame duck of universals - which is an exam ple of an 'anarchic' type of thinking, in which there is no 'paradox', but there is a 'double negation' a rhetorical device of Roman orators, which consisted of 'ridicule '(external jokes) and' negation (simple internal), like origami from two-color paper. Could the great Mechnikov defend his "theory of immunity" by introducing himself as an "alarm 
ist"? I don't think that even as a "demarche" this would be possible - hypocrisy in science was impossible a priori. But this is a hundred years ago. Pure visionary art - actionism and posturing crept into the "space of culture" (which contains both science and art) with pictures of a primitive

\section{REFERENCES}

1. Aristotelis fragmenta selecta, Recognovit W.D. Ross. 13. Menshikova, E. R. 2019. Trojan terrorism as a princiOxford, 1955. Quotes are from the Russian translation: $\quad$ pate of Deception, or in the arms of the terracotta Oxford, 1955. Quotes are from the Russian translation: Aristotle. Protreptic. Sense and Sensibilia. On memory. Russian translation. E.V. Alymova.-SPb.. Publishing

house of St. Petersburg University. 2004. p. 183

. Bunin, I.A. Cursed days. Reprint edition. Reproducing Quoted from. Collected Works of I. A. Bunin. v. 10, "Petropolis", Berlin, 1935. - M.: "Soviet writer", 1990.
$-176 \mathrm{p}$. $-176 \mathrm{p}$

3. Homer. "Odyssey". Trans. from ancient Greek. V. Zhukovsky. Canto XXII [St. 295, St. 306-309].- M Pravda, 1984, p. 272

4. Greek-Russian dictionary, compiled by A.D. Veisman. St. Petersburg, 1899. - Reprint of the V-th ed. - M.: Yu.A. Shichalin's Greco-Latin Cabinet, 2011

5. A short dictionary of Latin words, abbreviations and expressions. / Comp. V. Kupreyanova, N. Umnova.- M. TERRA, 1996, p. 75

6. Latin-Russian dictionary. O.A. Petruchenko.- Reprint of the $9^{\text {th }}$ edition of 1914 - M.: Eksmo, 2017

. Linguistic encyclopedic dictionary. 1990. Moscow, p. 685

8. Menshikova, E. R. 2020. "The double axe of myth (diphthong of Song): the forgotten flute of Greek Epigram justification of vileness, or total transformation "according to Fahrenheit" (cynic paradox) ", Art Literature Scientific and Analytic Journal Burganov House. The Space of Culture, vol. 16, no. 3, pp. 19-32. DOI:10.36340/20716818-2020-16-3-21-46

9. Menshikova, E. R. 2017. "Myth as a natural exchange (epistemological aspects of practical lies)", CredoNew no. 1-3.

10. Menshikova, E. R. 2019. "The natural landscape of philosophy (the political reflection of Heraclitus and Aristotle)", Art Literature Scientific and Analytic Journa Burganov House. The Space of Culture, vol. 15, no, 4, pp. 24-42. DOI:10.36340/2071-6818-2019-15-4-24-42

11. Menshikova, E.R. 2020. "Natural Landscape of Philosophy (Political Reflection of Heraclitus and Aristotle)" Art Literature Scientific and Analytic Journal Burganov House. The Space of Culture, vol. 16, no, 1, pp. 56-79. DOI:10.36340/2071-6818-2020-16-1-56-79

12. Menshikova, E. R. 2019. "Rondo of Myth: "Trojan terrorism" as an idea of exclusivity, or Caesar's summum bolocust (etymological wingcases of virtus). Parts. 1-3,

14. Menshikova, E. R. 2018. "Trojan terrorism: revenge of the colonists or condition of evolution? (to the prob.

Menshikova E. R. 2017. The natural landscape of philosophy (political reflaction of Heraclitus and Aristot-

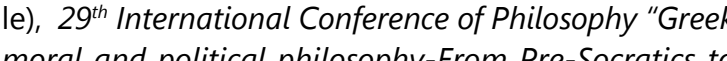
moral and political philosophy-From Pre-Socratics to Neo-Platonism" (Jule 7-11, 2017, Rhodes). Paper Ab-
stracts, Rhodes, 2017. stracts, Rhodes, 2017

6. Menshikova E. R. 2018. "The Natural Landscape of Philosophy (The Political Reflection of Heraclitus and A istotle)", Philosophy Study, vol. 8, no. 1.

17. Menshikova E. R. 2018. The Troyan Terrorism as an Established Order (Disciplina), or the Nomadic Colonatus (Mission of Mith in the space of Sir Thomas More's "Utopia"), International Relations and Diplomacy, February 2018, Volume 6, Number 2, (Serial Number 53). 18. Menshikova E. R. 2018. "The Trojan Terrorism: Revenge Colonists or Condition of Evolution? (To the Problem "Your/Alien")", Philosophy Study, vol. 8, no. 4.

9. Dictionary of foreign words. $7^{\text {th }}$ scientific editor. rework. ed. - M.: Sirin, 1996. $-608 \mathrm{p}$

20. Theophrastus. Characters. Trans., Article and approx G.A. Stratanovsky. Reprint ed. 1974.- M.: "Nauka" 2007.- 124 p. Freidenberg O.M. Image and concept. / Freidenberg O.M. Myth and literature of antiquity. M.: Ed. firm "Eastern Literature" RAS, 1998. P. 223-622. 21. Philosophy: an encyclopedic dictionary. ed. A. A. Ivina. - M .: Gardariki, 2006.

22. Philosophical Encyclopedic Dictionary. - M .: Soviet Encyclopedia, 1983, $840 \mathrm{p}$

23. Freidenberg, O. M. "The characters" of Theophrastus.Scientific notes of Leningrad State University. No. 63. Ser. philol. Sciences 1941, no. 7, pp. 129-141.

24. Thucydides. History. Trans. F. G. Mishchenko and S.A. Zhebelev, ed. E.D. Frolov. - SPb.: "SCIENCE", "YUVENTA" 1999 nature, where the desire to leave a tick-tick, "Hirsch test" (Soros, Oscar, Nobel) is stronger than the hidden meaning, when the Word, presented as "unprofitable", "superfluous", suddenly turns out to be "hypocritical." Paradox? No. Aggression. Foreign en"hypocritical." Paradox? No. A
ronment, foreign world.
Елена Рудольфовна Меньшикова

кандидат культурологии

эксперт

Новый Институт Культурологи e-mail: elen_menshikova@mail.ru

Россия, Москва

ORCID 0000-0002-5738-0732

DOI: $10.36340 / 2071-6818-2021-17-4-14-28$

\section{ПАРАДОКС ЛГУНА — НЕВЕРОЯТНОЕ ПОВТОРЕНИЕ ЧАСТЬ II. ДИФТОНГ «АРИСТОТЕЛЬ-АНОХИН»}

\author{
(ПРОДОЛЖЕНИЕ)
}

Аннотация: Прецедентов с обиженными инфантами 30-40 лет становится всё больше - они эмоционально не воздержаны, ибо находятся в искусственной коме инфантилизма, в которой 'желание' заменило 'жертвенность', и явно лицемерны, отчего Праздни гирлянду Конфликтов И войн, Создаёт турбулентную зону, в которой точки бифуркации вынесены наружу - за орбиту здравого понимания, обращая Сознание в тишайшего Сфинкса, плодя гипотезы. Крылатое выражение вольно-невольно может стать крылатой ракетой» - и разрушить весь мир, плох он или хорош, но теория, создаваемая предчувствием научного поиска, может помочь сохранить его в здравии и во плоти божественного замысла, но при одном условии: при паритете Ума, что парадоксами множит как сущности, так и сомнение, иьи ментальные альбатросы форматируют наше понимание. Так гипотеза, основанная на

Мое 'восприятие' (сущностного философа) начала 20-го года XXI века как «ответная реакция» на вокупности нестабильности бытия, поведенческой реакции и ментальных рефлексий) Аристотелем (384/383-322 гг. до н. э., Халхидики), античного философа-энциклопедиста, оказалось ближе и «роднее» мне, далёкому чужеземцу во времени и пространстве, чем восприятие учёного с мировым именем, нейрофизиолога, проф. Анохина К.В. (род. 1957 г., Москва), исследователя, казалось бы, тех же фундаментальных проблем науки: человеческого сознания. Мой современник и соотечественник, мало того, коллега в широком поле «онтологического знания», оказался непослушания, развешивая вкруг планеты мигающую соблюдении покоя и воли Сознания - непременном восприятие мира и сущностного человека (в со- парадоксе, формирует Образ Понятия и тем самым строит фундаментальный каркас мировоззрения, не у (он же лгун), как жена Цезаря, оказывается вне по-

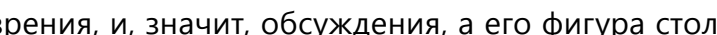

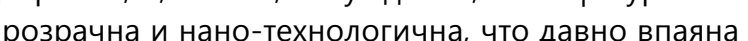
'шкалу погрешностей' всякого восприятия, - и это то беззубый кашалот, что подставил свою спину столпам мой, но и восчего не только маячит мудрой черепахой, но и воспринимается весёлым Буддой. Время о вемени кит открывает свой рот - и все мы оказываемся в его глотке, а сам лжец - вне Закона, вн которому ведома только доктрина исключительности и привычен пурпур бесстыдства.

Ключевые слова: Сознание, парадокс лжеца, Об раз понятия, сингулярность, 'множественная еди лицемерие, двоемыслие, формальный захват

противником самого Аристотеля, и хуже - ре зонёром. Привлекая высказывания учёных (архаического времени и современного), взятые из открытых источников, автор предоставил возможность читателю самому сделать вывод, то есть сложить собственное «понимание» 'воспри ятия' и собственно 'Әвижение мысли' человека, который способен формировать и форматироват 'мышление' и 'понимание', а главное, при этом заметить, насколько Сознание ангажировано (и кем рекрутировано) или же является следствием кропотливой и честной работы ума/разума говорящего (пишущего). ${ }^{1}$ Вводимое уточнение по Вводимое уточнение от 31.07.2021 г., сам материал напиконфликта, но в Праве: в правовом поле Абсолюта ничность', Смысл, насилие, континуум, дихотомия, 
просьбе редакции, по мнению автора, лишь обостряет проблему «парадокса лгуна»: сущностную проблему Обмана и «проблему лжи в науке», и нисколько не мешает Эйдосу, но прибавляет нашему «пониманию» печали. Продолжаем прерванную нить наших рассуждений.

\section{ВИТАЛЬНЫЙ КОНТИНУУМ}

Если исследовать пространство «бытия культуры» во всём «сумасшествии» её гармоничных соцветий, то нужен «свой» особый ментальный язык, что совьёт-заплетёт и протянет ленточки представлений, стянет ассоциативным узлом восприятия, передаст (точно-ёмко) «умозримое чувствование», которое явит «мыслимое» (осмысленное уже) восприятие того, что наличе ствует «здесь и сейчас», поскольку для каждого из нас другого мира (в органичном его виде) нет и не будет. Мой опыт складывается 'сейчас', но его фиксация происходит «восприятием» и помещается в коробочку «памяти» уже осмысленным - то есть Сознание сначала осматривает («ощупывает»), и, понимая, напрягая нейронные гривы эйдосов, само воспринимаемое, пробегающее мимо вас, иногда смеясь, иногда выбивая из седла, иногда поднимая с колен, вдруг обнимая, начинает складывать зеркальные осколки 'ментальных образов' в «весёлые картинки», и вбирая целиком, уверенно направляет к цели - центру «себя».

Термин «continuum» - «латинская бесконечность», на наш пристальный взгляд, Сознанию подходит больше, чем «когнитом» Анохина, поскольку старше по происхождению и ближе по смыслу: «в самом себе соединённый, продолжающийся без перерыва, непрерывный, беспрерывный, беспрестанный»². Это калька с латинского прилагательного, чей денотат напрямую зависит от проявляемых свойств конкретного предмета (признаки и проявления), означает «мозг человека», что являет собой «сплошную материальную среду, свойства которой меняются в пространстве

2 Continuus, a, um - непосредственно соединяющийся 1) в пространстве, а) с другим предметом (об одном, двух или более) соединенный, непосредственно прилегающий, непосредственно примыкающий, смежный; щийся, непрерывный, неразрывный, huтus (поэт): 2) во времени, а) с другим предметом (об одном, двух и более) непосредственно следующий один за другим; б) в самом себе соединённый, продолжаюицийся без пере рыва, непрерывный, беспрерывный, беспрестанный . 2017. C. 143). непрерывно» ${ }^{3}$ которая и представляет «совокуп ность всех мыслительных операций: меняющихся и быстротекущих». Философский словар не мог обойти ё, как сизифоО камень : тинуум (лат. continuum - 'непрерывное') - термин, используемый в математике, естествознании и философии. В математике под К. понимаются бесконечные множества, количественно эквивалентные множеству действительных чисел...<в> физике понимается идеализированная модель единого физического пространства-времени. В соответствии с представлениями общей теории относительности метрическая структура про странственно-временного континуума детер минируется распределением плотности вещества и излучения во Вселенной» ${ }^{4}$. Внимательно читая латинский словарь, можно обнаружить в чис ле прочих расширительных коннотаций и такой «oppugnatio» - 'приступ', 'нападение', 'штурм' 'атака', а все вместе - 'осадное искусство'. Дополнение обнаруживает пример «завидного постоянства», что фиксирует ментальная память и отражает язык - достаточно осмысленно огля деться вокруг себя: во времени и в пространстве, как окажется, что это «осадное искусство словно растворилось в «культуре бытия»: оно окрепло и совершенствовалось, мутировало различными формами, как вирус, ибо проявляет свою вирулентность нестабильностью социума, психологической неустойчивостью его граждан, международной нестабильностью планеты суетное - не гармоничное - существование которой де монстрирует именно 'незавершенный, перманент ный процесс' «постоянного переустройства». Как автор концепта «троянский терроризм», чьи корни усматриваю, прежде всего, в методе снасилия Цезаря», могу лишь заключить, что этот 'бесконечный процесс насилия' лишь совершенствуется: мір окаянством прирастает.

Но если учесть, что 'непрерывность' есть необходимое «условие развития» - общее для природы и человека, а значит и Сознания (пред3 Словарь иностранных слов. Указ. изд. С. 249. См.: «Понятие К. как одно из уточнений категории непрерывности имеет важные методологические функции тологическим статусом («природа не делает скачков») выступает необходимым условием истинности законов природы (и работы С.). В рамках диалектико-материали стических исследований понятие К. используется для ана10, прери ного» (Философский энциклопедический словарь. - М. Советская Энциклопедия, 1983. С. 275). метом нашего интереса, подчёркиваем, остается человек), и если помнить, что греческое слово

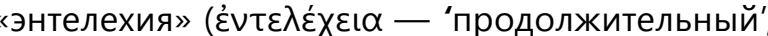
'беспрерывный') определяло суть философских воззрений: протоплазму научно-теоретического мышления, его ядерный заряд - ту движущую силу, что делает явью, материализуя Идею (цель), обладая необоримой ${ }^{5}$ стремительностью к развитию (жизненное начало), двигаясь к достижению, начиная от натурфилософских концепций до времён схоластических вплоть до Гегеля, то необходимая трансгрессия наблюдается невооруженным глазом или, как бы отметили иные, явны признаки конвергенции ${ }^{6}$, п потому уделим некоторое внимание греческой ипостаси этой "витальной непрерывности".

Философский словарь располагает ещё од-

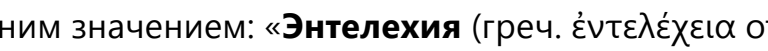
$\varepsilon v \tau \varepsilon \lambda \eta ́ \varsigma$ - законченный, завершённый и हैх имею, нахожусь в состоянии; собственно - нахождение-в-состоянии-полной осуществлённости осуществлённость), один из двух терминов философии Аристотеля (наряду с энергией) для обозначения актуальной действительности предмета акта в отличие от его потенции, возможности» ${ }^{2}$. И ещё одно: «Энтелехея (греч. - завершение, осуществлённость) - в философии Аристотеля: способ бытия вещи, сущность которой вполне реализована, форма, осуществляющаяся в материи ; активное начало, превращающее возможность в действительность, актуальность и тем самым исчерпывающее возможность или потенциальность» ${ }^{8}$. Между тем, если обратиться непосредственно к греческому языку, на котором ткалась философия Аристотеля, то определение будет более чем лаконичным, - оно будет обескураживающим по своей противоположной сути: «непрерывный, постоянный». Философская словарная статья опирается на слово, которого нет в гре ческом словаре - $\varepsilon v \tau \varepsilon \lambda \varepsilon \chi \eta\llcorner\alpha$, однако есть слово

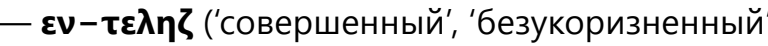

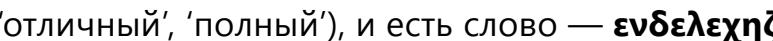

«Необорные руки Ахилла» - постоянный эпитет Гомера «Конвергенция (лат. converge - приближаюсь, схожусь) - сближение или совпадение двух и более лингвистиие-
ских сущностейм (Лингвистический энщиклопедический ских сущностейу (Лингвистический энциклопедический
словарь. - М.: Советская энциклопедия, 1990. С. 234). словарь. - М.. Советская энциклопедия, 1990. С. 234). цикософский энциклопедедия 1983. С 800 . Философия: энциклопедический словарь / под ред. А.А.
Ивина. - М.: Гардарики, 2006. С. 1014. ('продолжительный', 'беспрерывный')9. Истина в этом случае не просто посередине - она в другом слове - греческом $\varepsilon \boldsymbol{v}-\delta \varepsilon \boldsymbol{\varepsilon} \boldsymbol{\varepsilon} \boldsymbol{\eta} \zeta$, что означает 'беспрерывность и постоянную продолжительность, текущую непрерывно'. Грече ское начертание обнаруживает разницу значений. Не правда ли, похоже на гераклитовское: «Bсе течёт и всё изменяется»? Словно сама неудержимость мира вторит человеческой $\varepsilon \vee \delta \varepsilon \lambda \varepsilon \chi \varepsilon เ \alpha$ или, наоборот, что естественнее, она шла 'слепком' - мозг человека устроен очень сложно и как сложная «биоматрица» скрывает в себе не меньше, чем само мироздание, но работает лучшем случае на одну десятую своих возможностей. Итак, всплыли две различные субстанции: «непрерывная» и «законченная».

Куда делось изначальное толкование слова, вместе с его непрерывностью, протеканием, безудержностью, незавершённостью, длящейся не могущей прекратиться? Только с остановкой мозга (что являет факт смерти организма) прекращается разбег вашей энтелехии, поскольку именно её включает разум, получив импульс фактом своего рождения. «Энтелехия» и «интеллект - слова одной семы, значение которой опреде лено чётко в греческом словаре - «непрерывный», «постоянный», и в этом нас убеждают собственный опыт, и опыт других («опыт, сын ошибок трудных» (Пушкин)): мозг не умеет спать в лучшем случае это то, что мы называем «спящий режим»: даже во время короткого сна наш мозг «работает»: ищет, отслеживает, натыкается на аллюзии, сличает картинки, после чего одари вает нас инсайтом - дерзким прозрением, что заставляет открыть глаза, и, побудив к активным действиям, требует осуществления «показанного» в зримом образе или вербальном мысленном «звуке» (картины, часто цветные, слова, часто готовые фразы и рифмы). И само слово «интеллект» ('мыслительная способность человека') ни как не подразумевает свою собственную смерть, ведь его «конечность» и «завершённость» возможна только при 'выключенной лампочке', а е может гарантировать только смерть, что феноменальным образом останавливает феноменально устроенный аппарат мозга, что совершает мыслительные операции, отсылая импульсы в определённые зоны мозговых центров - той самой «галактики весом чуть более килограмма», что 9 Греческо-русский словарь, сост. А.Д. Вейсманом. - СПб.
издание автора, 1899. С. 432, 442. 
даже во сне продолжает «творить» и «дышать», иначе: 'протекать и непрерывно двигаться'.

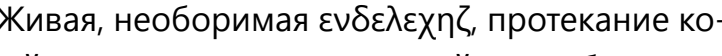
торой рвётся только остановкой всего биологического ритма организма (смертью сердца или насильственно), никак не может члениться на логические или нелогические фразы, её потенции неисчерпаемы, она не осуществима в полноте своей, поскольку её «дно» (предел, масштаб, объём) не определено, и нельзя сказать, что её «сущность реализована» до конца, ибо предначертанных заданий может быть множество, $n$ пока мозг, в котором она обитает, жив, не обесточенный энергетически (жизненным током) и тем обеспечивая его работу, - золотая рыбка

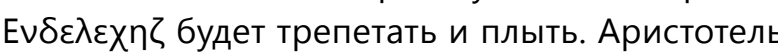
в «Протрептике» настаивал на постоянном движении человека к счастью - за гармонией, за созвучием ладов «Я» и «мира», что возможно лишь при ладно работающей «энтелехии», ведь потому и надо «обратиться к философии, если мы собираемся правильно вести общественные

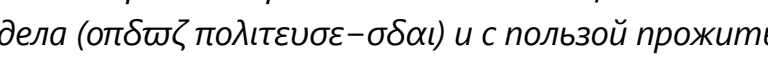

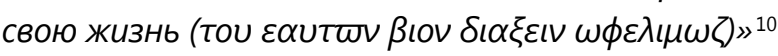
Иначе, быть готовым и вовлечённым к свободе мышления, или владеть политической рефлекси ей в объёме переменного тока жизни. ${ }^{11}$

Итак, континуум суть витальная непрерыв ность, она же энтелехия, и считаем, при опи сании (умозрительном, разумеется) уместнее/ точнее использовать эти 'имена', ибо денотат отражает и сущность феномена Сознания, и его причинность и необходимое условие, поскольку «связывать смыслы в бесконечные узлы»занятие, аналогичное плетению сетей, и являе не только 'самое себя' как «сеть сетей», словно манекенщица, - подиум именно что внутри, а сами показы возможны только опосредованно - через предметы/продукты вашего Сознания (любое воплощение, но материальное воплощение), и собственно «презентация» не входит часть его непосредственных обязанностей - это

10 Aristotelis fragmenta selecta / Recognovit W. D. Ross. Oxford 1955. Цитаты приводятся по русскому переводу: Аристо-
тель Протрептик. О чувственном восприятии. О памяти Пер. на рус. Е.В. Алымовой. - СПб: Изд-во С.-Петербургского ун-та, 2004. С. 25.

Меньшикова Е.Р. Натуральный ландшафт философии (в 2-х частяХ) // Дом Бурганова. ПРОСТРАНСТВО КУЛЬТУРЫ, ㄱ 4. 2019. С. 24-42; № 1. 2020. С. 56-79. Английская версия Landscape of Philosophy (The Political Reflection of Heraclitus and Aristotle) // Philosophy Study, V. 8, N. 1, 2018. скорее вспомогательная функция, но Сознанию важно именно сохранять и поддерживать непрерывность целеустремленных движений мысли, ют в результате чувственных восприятий, проходящих процесс умозрения в режиме онлайн - то есть «здесь и сейчас», как выразился Аристотель, в непосредственно данное время - и оно создаёт 'самое себя' (что важнее и ценнее) — то «жизненное начало», что есть живительная сила - и пролагает себя непрерывно причём, не делает остановок, не зависает в подсчётах, не сдерживая себя в мысленных интенциях, - воспринимает, непрерывно связывая и сближая впечатления и отражения, осмысляя как бы обнимая, сохраняя, мыслью, но при этом не устаёт анализировать, контролируя, совершая осмысление, бросая и направляя объект/предме восприятия на другую плоскость, перемещая пространстве-времени. Ключевое здесь: «безостановочное прилегание к другим» - конвергенция и трансгрессия - 'взаимопроникновение' и 'переплетение', и не только 'касание', здесь происходит взаимодействие ваших собственных разных и всяких чувственных восприятий-энтелехий - 'непосредственно соединяющихся', 'непо (c)

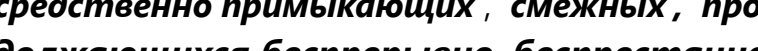

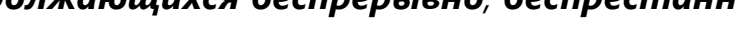
- в пространстве-времени с другими, таким же скорыми на подъём, взлёт и посадку, воспри ятиями-отражениями Других - иных и разных — это и создӓт бесконечний континуум вашего Сознания и самой жизни во всей её бездонной иппер-нескромности к самой себе - виталь-

Всё это нейрофизиолог Анохин окрестил «вилами на воде» (см. выше), по его мнению, вся эта «описательная чушь» (философия) при изучении Сознания не нужна, но при этом «изобрёл» словечко (а по-нашему, оторвал лягушке лапки: cogito - лат. 'Әумать', 'мыслить' - привычным для биолога движением - расчленил), чтобы отказаться от главного - поиска «причинности», то есть Смысла - этого основного предназначения Знания. Зачем? - не менее важный вопрос сре ди прочих, который ставит перед собой человек познавая мир. Вместо этого нам предложена ( от кажется, уже поговаривают о государственной программе поддержки) модель не «осмысления мира» - но сверкающую модель «когнитивного опыта», что «помирит мозг и психику, решит одним... махом «проклятую» психофизиологи ческую проблему» (см. интервью выше). То есть причина всё же есть, но она, вот незадача, про клята! И чтобы снять «заклятье», нам предлагается ве коги сосчитать и разложить по скляночкам с иветными бирочками, предавшись воспоминаниям, ибо индивидуальный опыт «проживает» именно там - в области прошлого, при этом забыть о настоящем - суетном и таком бестолково-ненужном, для чего следует приготовиться к сложной и кропотливой работе, ибо считать вам придется коги пока у червячков и рыбок, потом у мышек и макак, а дойдёт ли очередь до человека - никто не знает - молчит гиперсеть, не даёт ответа. Конечно, умолчит, поскольку червяк точно не узрит «проклятой психофизиологической проблемы» человека - масштаб другой: где он? и где проклятье? и главное: в чём оно для червяка? И пока профессор, исследуя мозг мышки током, вызывает 'опыт переживания' буквально: собирая 'индивидуальные' «опытные образцы» мышиных когов, постигая - нет, складывая полученные образцы в совокупность всех «мыслительных операций мышки», то есть до того, как она почит в бозе от электростимуляции, есть вероятность, что «заклятье» снимется и прежде всего с мыслительного процесса, но самого человека (надеемся на это). Если программа «Когнитома нацелена на изучение Сознания (человека, полагаем?), то зачем собирать опыт переживания мышей? Чувствительно-осязательный шок крысы не объяснит процесс вдохновения у человека даже порядковым номером кога.

Неожиданно для человека в наши нестабильные будни начала 3-го тысячелетия актуальный запрос на 'Сверхчеловека' сменился слиянием двух лун - конкуренции и глобализма, что вызвало

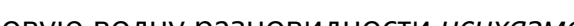
ливое погружение в нервную деятельность первичноротых и грызунов». Видимо, настало время для 'искупительной жертвы' - за все прегрешения перед тварями земными и земноводными, всеми гадами ползучими и морскими - самого человека, существа никчёмного, негодного (даже для исследования, но, может быть, для кунсткамеры), словом, «проклятого» и ненужного? Кто возьмётся определить степень «нужности» человека? Его «человечность»? Его важность? Осмелюсь спросить: поскольку исследователь - человек, то его «понимание» будет «человеческим» (с точки зрения человека), а мышь будет испытывать те же чувства и эмоции, те же образы возникнут/на- пугают/обескуражат её, что и экспериментатора? Антропоцентризм не помешает вместе со слезами мышки высчитать коэффициент бесплотных усилий бессмыслия? При 'объяснении' и 'пониусилй бессм важне, как мне кажется, сохранять тот терминологический арсенал, что наработан веками, а не плодить сущности лексического беспорядка, пусть и тяготеющие к собиранию множества, что вторичны ибо тавтологичны. Эмоции (мыслительные в том числе) у всех разные: по силе яркости, скорости, цветопередаче, доле, причи не, волеизъявлению, направлению, подаче) и вс они влияют на те чувственные восприятия, что потом и сплетаются в «осмысление» и «понимание». Можно сказать, что это 'сегменты червячка', что вам доставят терру - крупицу «представ ления» как осязаемый комочек - с ромашкой или эдельвейсом, но уже «переработанного» осмыслением, то есть умозримым восприятием.

Занятия поэзией, рисованием, сочинение музыки - всё это укрепляет не просто работу мозга, но, тренируя, поддерживает в тонусе «мышцы Сознания: восприятие, представление, осмысле ние, воображение - обязывая таким образом организм вырабатывать самостоятельно необходимый 'эндорфин', и в достаточном количестве для конкретного человека, создавая условия для гармоничного существования и вместе с тем готовя абрис своей аструктурности. Из одного вопрошания жизнь не состоит - нужно ещё созидание - каждого/каждым - и без этого жизнь - звук пустой и безучастный, скорбный, как палый лист, а потому, прокладывая путь к новому, я повторяю своё определение: Сознание - это 'самоорганизующийся Хаос', что действует как «резонансная система» в структуре 'диссипативного Бытия', рождая эйдосы восприятий и пряч кванты Смысла в искусство, вырабатывая 'фермент сопротивления' «бытию-в-мире», а потому это ещё и 'искусство сопротивления'.

А сопротивляться нужно и можно по-разному, важно замечать «двоичный код», за которым прячется циничный формальный разум, забывая что 'прозрачность' услужлива и коварна. И нужно просто знать: тот, кто оперирует «формальным разумом», используя и прибегая к «парадоксу лжеца»: формализуя буквально грамматически и стилистически, то есть языковыми стереотипами публичного убеждения, подобно 'насилию Це заря', паразитируя на «двоичной посылке», что стелется ковровой дорожкой лицемерия, гото- 
вой затянуть лассо, осуществляет формальный захват - каверзой 'двойного дна' - Обманом.

О Лжи - «Даме риторической» - рассуждали Бахтин и Булгаков, размышляла Фрейденберг, Хармс замечал её в «кровавом исподнем», Кржижановский и Шостакович искали и находили формы её отражения в искусстве (практически одновременно - в 20-х гг. XX в.), выстраивая свои сомнения вокруг 'паяца', что был «лжечом» в высоком понимании — как 'жрец иносказания', но который оказался «пройдохой», и с практической точки зрения это не допускало «противоречия» поскольку ему знакомы «закоулки» бытия, ведома суть мироздания: жизнь - в самой жизни, и значит, в глубине міра всегда найдётся выход из «не-бытия», но также есть и уголок для корысти, что самой жизни (органической) только способствует. Выгода? Детерминированная эволюцией? Какой ценой? Во сколько обходится паника «простимулированной» мышки? А человека? В момент обстрела? А паника при обнаруженном обмане? Если собственного опыта маловато, то можно полюбопытствовать у «прошлогоднего снега», под которым обнаружишь чьё-то «ускользнувшее восприятие».

И как такой скользнувший смыслом лик реплика-крик Ивана Бунина: «Лжи столько, что задохнуться можно. Все друзья, все знакомые, о которых прежде и подумать бы не смел, как о лгунах, лгут теперь на каждом шагу. Ни единая душа не может не солгать, не может не при бавить и своей лжи, своего искажения к заведо мо лживому слуху. И все это от нестерпимой жажды, чтобы было так, как нестерпимо хочет ся» $[2$, С. 59], и которую писатель тонкой нерви ческой одарённости сопровождает пояснением прорицателя - прозрением удивительной точности: «В этом и есть секрет большевиков убить восприимчивость. Люди живут мерой, отмерена им и восприимчивость, воображение, - перешагни же меру. Это - как цены на хлеб, на говядину. «Что? Три челковых фунт!? А назначь тысячу - и конец изумлению, крику, столбняк, бесчувственность. «Как? Семь повешенных!?» - «Нет, милый, не семь, а семьсот! - И тут непременно столбняк - семерых-то висящих ещё можно представить себе, а попробуй-ка семьсот, даже семьдесят!» [2, С. 67]. убить восприимчивость! Считаем, это и есть та утрата 'внутреннего зрения': способность воспринимать «чудовищное» как 'чудовищное' что привела к помутнению рассудка, помешательству всеобщему, явилась причиной лексического оскудения, или человеческого «безъязычия», при безудержной тяге к насилию. Словно чиркнули ножиком 'воображение', рождённое ахами детства и любопытством юности, что наполняли крылатыми образами, пробуждая Образы поня тий, а с ними и смыслы - прямые, однозначные двузначные, многозначные - ясные и разумные а с ним и способность самостоятельного мышления, - и словно произошло затемнение в хрусталике глаза - не различить подлеца-лжеца. И это впустило архаичного гибриста анархическим Хамом - разгульным, отважным, диким, бесстыдным циником, разрешило совершить разорение міра, позволив Интернациональной Лжи воцариться в России довольно быстро и распластаться там худой рукавицей. Потеря 'остроты зрения' всегда возможна при сильных умственных перегрузках, что связано с напряжением зрительного нерва, но таким колоссальным 'перенапряжением' для России стала Первая Мировая война, что тянулась четыре года и привела «истощением Сознания» русскую нацию к деградации - состо янию опустошённого мышления. Затем все восстановилось - не сразу и не надолго, но это другая история - о ней потом.

Поскольку моё собственное восприятие Лжи в то время, когда задумывалась и писалась диссертация, не было столь 'катастрофичным', то отмеченная (ещё тогда) цитата Бунина из «Окаянных дней» (что только в 90-м году были опубликованы в России) просто осталась как «цитата», и лишь сейчас я ощутила в ней жар «ускользнув шего восприятия», и что так важен стал мне как 'аргумент современника' (если не одной временно́й, то одной пространственной культурной параллели), увидевшего и узревшего причину социальной катастрофы именно во Лжи. Согласимся с писателем и продолжим: 'утрата восприимчивости', о которой режиссер К. Муратова говорила каждым своим фильмом, взывая взыскуя справедливости, изображая «астениче ский синдром» как 'астеничность Сознания, что лжет': постоянно, время от времени, лукавя искажая, иронизируя, издеваясь, лицемеря - и тем меняя баланс восприятия: чрезмерностью мелкого, частного, приватного Обмана Как 'уловка' - часть чужой игры, эта насильно и подлогом приобретаемая 'невосприимчи вость', вторгаясь в «систему ментального пи щеварения», приучала к 'двойным посылкам', как к чипсам, которыми нельзя «напитаться», но можно «обмануть» голод, - так постепенно заменили весь «рацион» Сознания (и современные реалии тому подтверждение - беда всеобщая) и так взрастили 'непонимание', что оказалось вирусом конфликта, очевидного «незрячестью» и жестокого в лести и равнодушии.

Отчего «насилие» так неизбывно? - возможно ли завершение? Это «проблема Сознания» что для самого Сознания остаётся неразрешимой пока. Однако именно «страсть к насилию» обнаруживает современную профанацию научного знания, загнанного в современные рамки «цифровой оптимизации», но и вообще Знания, что оказалось оболганным и ошельмованным Невежеством. И потому, как нам думается, проблема, как всегда, на поверхности - она в угнетении «характера». И здесь «опыт ментальных зарисовок» Феокрита может послужить определённым лекарством и подспорьем. Заметим от себя, Циник (он же гибрист) появляется только на волне “цинизма» - нигилизма всего при незнании много, и только копьём гибризма - издёвкой

БИБЛИОГРАФИЯ

1. Aristotelis fragmenta selecta / Recognovit W.D. Ross. Oxford, 1955. Цитаты приводятся по русскому переводу: Аристотель. Протрептик. О чувственном восприятии. О памяти / Пер. на рус. Е.В. Алымовой. СПб:: Изд-во С.-Петербургского ун-та, 2004. - 183 с

2. Бунин И.А. Окаянные дни / Репринтное издание. Воспроизв. по: Собрание Сочинений И.А. Бунина. - Т. 10. - Берлин: Петрополис, 1935. - М.: Советский писатель, 1990. - 176 с

3. Гомер. Одиссея / Пер. с древнегреч. В. Жуковско го. - Песнь XXII [St. 295, St. 306-309]. - М.: Правда, 1984. - С. 272.

4. Греческо-русский словарь, составленный А.Д. Вейсманомъ. - С.-Петербургъ, 1899 / Репринт V изд.М.: Греко-латинский кабинет Ю.А. Шичалина, 2011

5. Краткий словарь латинских слов, сокращений и выражений / Сост. В. Купреянова, Н. Умнова. - М. TEPPA, 1996. - C. 75

6. Латинско-русский словарь / О.А. Петрученко / Репринт 9-го издания 1914 г. - М.: Эксмо, 2017.

7ингвистический энциклопедический словарь. М.: Советская энциклопедия, 1990. - 685

8. Меньшикова E.P. Double ахе Мифа (дифтонг зонга): Забытая флейта греческой эпиграммы / Оправдание подлости, или тотальная трансформация «по Фаренгейту» (парадокс циника). - Ч. I // Дом Бурганова. Пространство культуры - 2020 - № 3. - С 21-46. и натиском невежды, его агрессивной ложью. При этом парадокс лгуна являет собой «закон исключённого третьего», или хромой утки универсалий - что есть пример 'анархического' типа мышления, в котором нет 'парадоксальности', но присутствует 'двойное отрицание' - риторический приём римских ораторов, что складывался из 'осмеяния' (шутки внешней) и 'отрицания' (простого внутреннего), словно оригами з двухцветной бумаги. Мог бы великий Мечников защищать свою «теорию невосприимчивости", отрекомендовавшись «алармистом»? Не думаю, что даже как «демарш» такое было бы возможно - лицемерие в науке было невозможно апри ори. Но это сто лет назад. Визионерство чистой пробы - акционизм и позёрство - вползло «пространство культуры» (что вмещает и науку, и искусство) картинками примитивного свойства, где желание оставить крестик-галочку, «зачет по Хиршу» (Соросу, Оскару, Нобелю) сильнее потаённого смысла, когда Слово, представленно как «нерентабельное», «лишнее», вдруг оказывается «лицемерным». Парадокс? Нет. Агрессия Ино-среды, ино-мирия.

9. Меньшикова Е.Р. Миф как натуральный обмен (гносеологические аспекты практической лжи) // CredoNew. - 2017. - № 1-3.

10. Меньшикова Е.Р. Натуральный ландшафт философии (политическая рефлексия Гераклита и Аристотеля) // Дом Бурганова. Пространство культуры. 2019. — № 4; 2020. — № 1

11. Меньшикова Е.Р. Рондо Мифа: "Троянский терроризм" как идея исключительности, или summum bonum Цезаря: насильем покоряйте мир! // CredoNew. -2019. 一 № 2 .

12. Меньшикова Е.Р. Троянский терроризм как принципат Обмана, или в объятиях терракотовой саранчи (этимологические надкрылья virtus). Ч. 1-3// CredoNew. - 2018. — № 3-4; 2019. — № 1.

13. Меньшикова Е.Р. Троянский терроризм: условие эволюции или месть колонистов? (К проблеме «Свой/Чужой») // CredoNew. - 2018. — № 1.

14. Menshikova E.R. The natural landscape of philosoph (political reflaction of Heraclitus and Aristotle). // 29 International Conference of Philosophy "Greek mora and political philosophy-From Pre-Socratics to NeoPlatonism" (Jule 7-11, 2017, Rhodes). Paper Abstracts. - Rhodes, 2017

15. Menshikova E.R. The Natural Landscape of Philosophy (The Political Reflection of Heraclitus and Aristotle) Philosophy Study _-Volume 8. _ Number 1 _ 2018 
16. Menshikova E.R. The Troyan Terrorism as an Established Order (Disciplina), or the Nomadic Colonatus (Mission of Mith in the space of Sir Thomas More's "Utopia") I/ International Relations and Diplomacy. - February 2018. - Volume 6. - Number 2 (Serial Number 53).

17. Menshikova E.R. The Trojan Terrorism: Revenge Colonists or Condition of Evolution? (To the Problem "Your/ Alien") $/ /$ P

18. Словарь иностранных слов / Изд. 7-е, перераб. науч. ред. АГ. Спиркин. И.А Акчурин. Р.C. Карпинский - М.: Сирин, 1996. - 608 с.
19. Феофраст. Характеры / Пер., статья и прим. Г.А. Стратановского; Репринт изд. 1974. — М. «НАУКА 2007. - 124 с.; Фрейденберг О.М. Образ и понятие // Фрейденберг О.М. Миф и литература древности. - М.: Изд. фирма «Восточная литература» РАН, 1998. -С. 223-622.

20. Философия: энциклопедический словарь / Под ред. А.А. Ивина. - М.: Гардарики, 2006

21. Философский энциклопедический словарь Советская Энциклопедия, 1983. $-840 \mathrm{c}$.

22. Фрейденберг О.М. «Характеры» Теофраста // Уче- Вып. 7. - С. 129-141.

23. Фукидид История / Пер. ФГ Мищенко и СА Жебе. TA, 1999

Mikhail S. Bankov

Postgraduate student of the Stroganov Moscow State Art and Industry Academ Department of Art History and Humanities

e-mail: bankoff3@yandex.ru

Moscow, Russia

ORCID 0000-0003-2414-822

DOI: 10.36340/2071-6818-2021-17-4-29-48

\section{TO THE QUESTION OF SPACE ORGANIZATION OF BOOK ILLUMINATION OF LATE ANTIQUITY AND EARLY MIDDLE AGES (IV - VII CENTURY)}

Summary: The article focuses on peculiarities of spatial organization of book miniature paintings of late antique and early medieval manuscripts (IV - VII centuries). The author analyses the problem of conveying illusion of depth in illustration in context of gradual transmission from roll to codex, which took place in antique book culture between the II and the $V$ centuries. By analyzing survived fragments of illuminated rolls author displays characteristic features of their spatial organization and observes influence which had tradition of roll illustration on the development of codex. Nevertheless, precisely the miniatures of the codices that have come down to our time are in focus of the author's attention. The stages of development of the text page, the peculiarities of interacvelopment of the text page, the peculiarities of interaction of text and images in codices are compared with the
principles of space organization in miniatures. The article makes an attempt, relying on the monuments that have survived to our time, to consider the development of spatial constructions in the period of late Antiquity and early Middle Ages as a continuous process of evolution of the anguage of book painting The author assumes that the deve ing does not imply sharp breaks or regression. Each new

ing does not imply sharp breaks or regresion. Each new

The art of the period of transition from the late Antiquity to the Middle Ages was an extremely important stage in the development of European culture. At this time the foundations of medieval art were laid. This era was of particular importance for the art of book miniature. During this period, such process of exceptional importance as the formation of the codex took place as well as the development of the fundamental principles of interaction of text and images in the book. Such an intensive development of the book art in the transitional era makes the issue of organizing space in late antique minia- makes it possible to expand the arsenal of artistic means Which are necessary for solving artistic problems of the time. In accordance with this approach, the article concentrates not only on compositions in which a spatial itlusion is created, but also miniatures that are in character more plane. As a result, the author reveals the main types of spatial constructions, considering all surviving monuments of miniature painting of that time. For each type of space organization, the author identifies the basic principles and artistic techniques that allow the artist to convey a sense of depth on the plane of page. The author pays special attention to the comparison of illusionistic tendencies in the late antique book miniature and "reverse perspective" features of which are present in the monuments of the era. The author casts doubt on the need for a sharp contrast between these two approaches to space organization in the monuments of book miniatures of the era. He analyzes the reasons for the appearance of such features of space organization in miniature paintings of te antique and early medieval manuscripts, which are so important for the formation of artistic language of me eval book illumination.

Keywords: spatial constructions, reverse perspective, Antiquity, Middle Ages, book miniatures.

tures especially significant. Several highly respected scientists have touched upon this topic in their treatises. Nevertheless, the study of spatial constructions in the monuments of the book art for a long time was of a selective nature. The researchers focused mainly on miniatures inherited the tradition of antique illusionism. On the contrary, the principles of space organization in the compositions with no illusion of depth remained for a long time "outside the brackets" of art historian research. Studies of spatial constructions in the medieval painting of the 20th century, to which Russian scientists have 


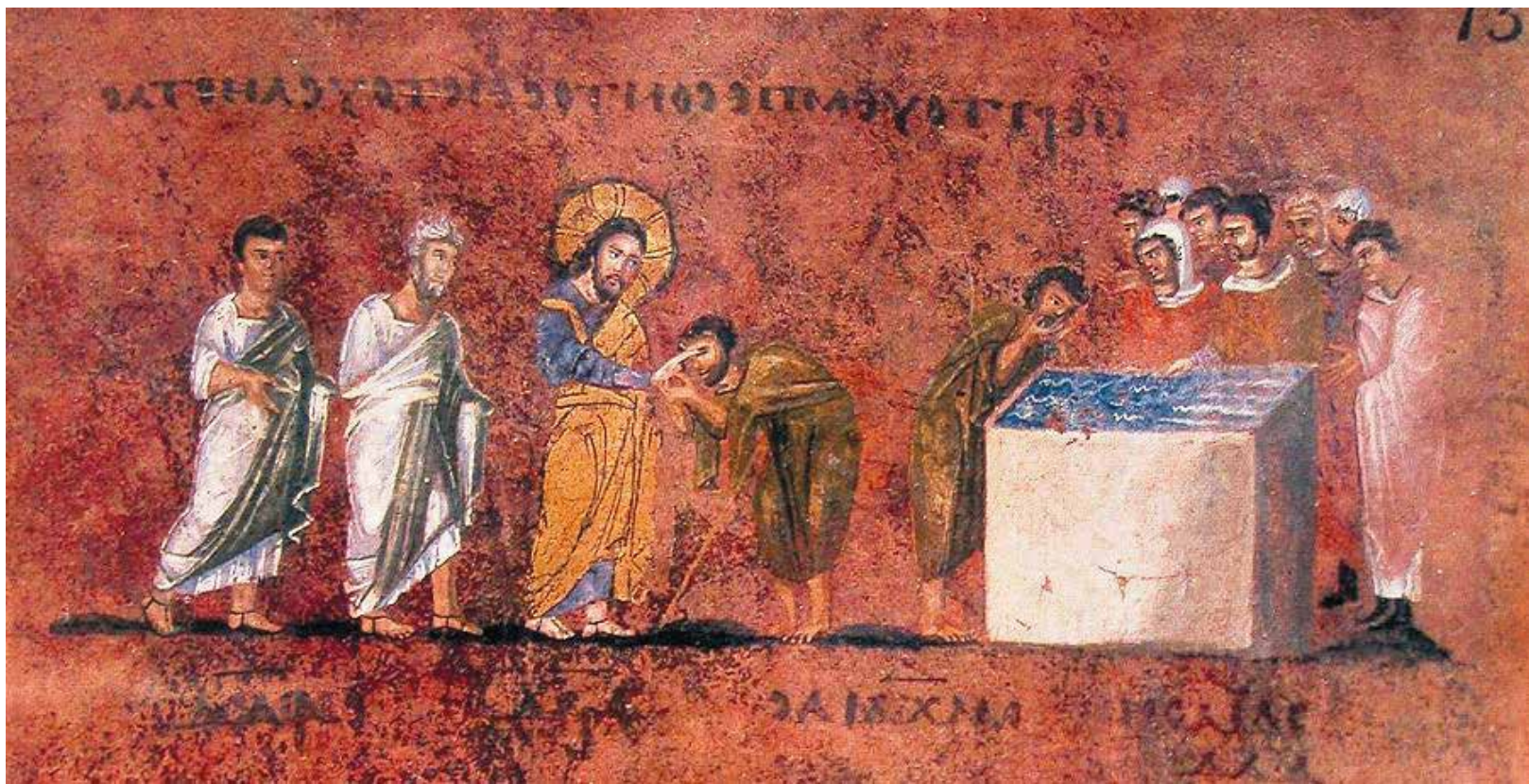

IIl. 1. Museo Diocesano di Arte Sacra di Rossano, Codex Rossanensis, folio 13 r.

made a significant contribution, allow relying on the preserved monuments to define a single line of logic of spatial constructions development in the late antique book miniature and highlight the main types of space organization in illustrations. This is the goal of this article.

The rise of the book miniature art in the late antique period related, according to the researchers, to the emergence of a new text medium which technical features also provided new opportunities for artists ${ }^{1}$. It is a question of the gradual transition from the papyrus roll to the parchment codex which took place between the 2 nd and 5 th centuries $A D^{2}$. Nevertheless, until the 3 rd -4 th centuries, the papyrus roll still remained to be the principal text medium. It is known that in the Antiquity there was a tradition of roll illustration dating back to the Egyptian manuscripts ${ }^{3}$. The surviving fragments of illustrated papyri, the earliest of which dates back to the 2-d century $B C^{4}$, give the opportunity to suggest that illustrations of ancient rolls were located directly inside narrow text columns. The miniature literally interrupts the text and offers a visual equivalent to the part of the narrative next to which the illustra-

1 Andre Grabar et Carl Nordenfalk. - Le haut moyen age du quatrieme au onzieme siecle. Geneve, Skira, 1957; $\mathrm{K}$
Weitzmann, Illustraitions in Roll and Codex, Princeton University Press, 1970, p. 57

K. Weitzmann, Illustraitions in Roll and Codex, Princeto

University Press, 1970., p. 69-70.

Ibid, p. 59 and late

University Press, 1970., p. 49 tion is located 5 . The "papyrus style of illustrated rolls compositions was reproduced in codices during several centuries and significantly influenced the development of the art of book design. Certain features of space organization correspond to this type of miniatures.

An important peculiarity of roll illustrations is that the images are located directly on the surface of the papyrus sheet. This way, the action develops without any spatial environment. Most likely, this is due to the technical feature of the medium: the constant need to fold the papyrus would inevitably lead to damaging the image and, ultimately, to its destruction? ${ }^{7}$. At the same time, the arrangement of the miniatures directly on the plane of sheet, likewise text elements, strengthens the connection between text and image. The fact that the action of illustration develops horizontally from left to right emphasizes the connection between narrative and its visual equivalent. The focus of the artist's attention is on the images of characters which, like words in a text, are combined into a non-verbal narration.

The location of images and text in a common field entails a specific subordination of the image to the surface of the sheet. As a result, the illustration acquires planar character. It is interesting, that such an attitude to depiction is the opposite of the

5 The illustration format, consequently, depends on the size of the text column, most of all, on its width

scientific

University Press, 1970, p. 52-53.

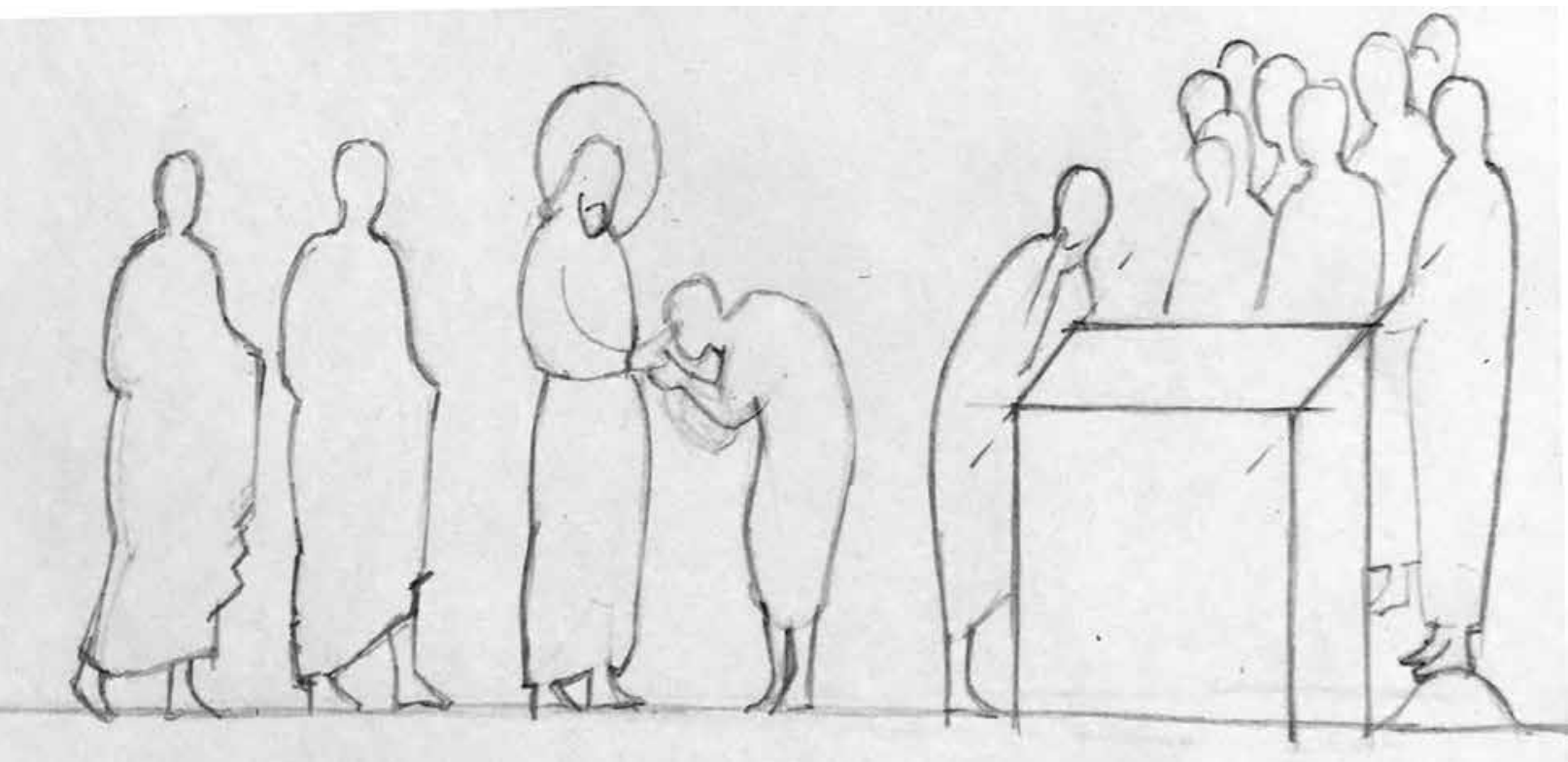

III. 2. Codex Rossanensis, folio 13 r, drawing.

development of illusionistic tendencies in antique monumental fresco painting ${ }^{8}$. It can be assumed that the close connection between text and image in roll illumination requires that the illustration "main tains" visually the solidity of the sheet surface. It is also understandable that there is no treatment of light and shade in the representation of a body which would violate the integrity of the sheet surface "weighing upon" and breaking it. On the contrary, the planar character of the images perfectly corresponds to the requirement of preserving and manifestation of the plane of the sheet.

However, the planar nature of images and the absence of the environment does not mean the absence of certain spatial relationships in the compositions. Thus, a very important artistic mean of constructing space in roll illustrations is the method of "superimposition" of one image on another. By showing one figure overlapping the other, the artist demonstrates the presence of several spatial plans in the composition. A good example of utilization of this technique is a fragment of a miniature with a group of horsemen from the Johnson Collection (4th-5th centuries). Here two spatial plans appear due to the fact that the horsemen located below overlay the figures located above.

The method of superimposition is closely related to another technique which we can designate as the "vertical displacement" method. The essence of this artistic mean is that one image is slightly re-

8 K. Weitzmann, Illustraitions in Roll and Codex, Princeton 9 Bauerische Staatsbibliotek, Munchen, gr. mon. 138. moved vertically with respect to the other image. As we know, an object located closer to a person on the retina of his eye is placed lower than the same object located further away. The ancient artists reproduce this vertical displacement of images on the plane of sheet as an artistic method which indicates the spatial relationship between the depicted figures. As an example of utilization of this method we can mention an illustrated fragment of a parchment roll from the Bavarian State Library (IV century AD) ${ }^{9}$. According to Kurt Weitzmann, the drawing appears to be an illustration for the Iliad. It depicts the moment when Talfibius and Eurybatus lead Brizeis away from Achilles. The artist places one of the accompanying men lower than the other two figures. Thus, the master disposes one personage in the foreground and removes the others to the background creating in such a way two spatial plans.

The examples above allow us to assert that the specific spatial relationships characteristic of the "papyrus style" were elaborated in the ancient roll illustrations. The arro conveying space in the true sense of the word provides a system of plans which indicate spatial exfoliation in the composition. This system has bee used in several late antique codices that have come down to us in which artists reproduce the same type of space constructions. 
One of the surviving manuscripts is the so-called Sinope Gospels from the National Library of France (6th century) ${ }^{10}$. On the folio $29 \mathrm{r}$ a scene of the healing of a blind man by Christ is represented. As in roll illustrations, the action develops along the horizontal axis. The figures of the Saviour and the other characters are united by a barely noticeable thin ground surface line. The author represents the images in a planar manner: the legs and feet of the characters, resting on the ground surface line, are depicted in profile, while the torsos are deployed to the front. Nevertheless, in the miniature painting as well as in the fragments of illustrated rolls, there is an indication of spatial relationships between the characters. The master also uses the technique of "superimposition": the figure of one blind man overlaps the figure of the other as well as one of Christ's followers hides behind the others, so that we can only see his head. Thus, the miniature of the Sinope Gospels reproduces the system of spatial plans characteristic of roll illustrations.

An important tendency of papyrus style miniatures in codices is the appearance and the development of the ground surface line uniting the figures in the composition. So, while in the Sinope Gospels the representation of the ground surface is just an abstract line, in the scene of the resurrection of Lazarus in the miniature of the folio 1 of the Rossano Gospels (6th century) ${ }^{11}$ the line is much less abstract. The artist reproduces the surface irregularities depicting how the basic line of the earth transforms into the image of a rock with the tomb. Thus, we can speak about gradual development of the spatial layer, still rather abstract, which unifies the space of the environment. This tendency is even more noticeable in the lower register of the miniature of the folio 16 of the same Rossano Gospels where the basic line resembles a hilly surface of the earth presented as in a "sectional view".

However, we have to lay stress upon the fact that at this stage the line still remains only a sign of the ground surface. Likewise the horizontal line drawn by the scribes in order to maintain the unity of the string, the ground surface line combines the images of the composition into a narrative. The lat antique artist focuses on the visualization of this narrative, his main goal is to transfer the necessary

10 Bibliothèque nationale de France, Manuscrits occidentaux

suppl. grec 1286, I
Museo Diocesano di Arte Sacra di Rossano, Codex Rossanen-

sis information for understanding of the development of the plot, of the characters and the objects around them. In certain cases, the principle of visualization of the narrative requires the master to reproduce the depth of the particular objects which are most commonly buildings or some kind of architecture. This leads to a contradiction between the horizontal ground surface line uniting the images, the general planar nature of the composition, on the one hand, and the demands of the principle of visualization of the narrative, on the other. In such cases, masters are faced with the difficult task of combining these two contradictory moments.

One of the ways for solving this problem is to combine different points of view in the representation of an object. This way, in the miniature of the folio 13 of the Rossano Gospels (Fig. 1, 2.) dedicated to the healing of a blind man the artist represents "the Pool of Siloam" as a parallelepiped. The artist depicts the upper part of the bath from a higher point of view drawing it in accordance with the principles of axonometry. The most probable purpose for reproducing the depth of the pool is to demonstrate the surface of water which is necessary for visualizing the function of the object in the story. At the same time, all other images of the composition are subordinated to the principle of planeness developing along a horizontal ground surface line. Thus therefore, in order to underline the stability of the parallelepiped, the artist depicts its lower part in planar manner leaning on the same horizontal line. For that the master disproportionately, as it seems, lengthens the distant part of the side of the pool. Thus, the artist combining several perspectives re produces the volume of the object and, at the same time, lines up all the images on one horizontal line. This way the plane of the sheet is not disturbed. Such artistic techniques of space construction become more and more frequent since the 6th century.

Another way is to attach a three-dimensional image to the ground surface line without distortion making, the miniature of the folio $4 v$ of the Vienna Genesis (I half of the 6th century ${ }^{12}$ dedicated to the promise given by God to Abraham about his countless posterity. In the left part of the upper register of the composition, we can see Abraham sleeping on a bed. The master depicts the couch in accordance with the principles of axonometry without distortions. The long side of the parallelepiped develops diagonally, so that the distant edge is removed upwards. The depiction of the sofa should have presupposed, as it seems, a corresponding surface plane depicted from the high point of view. On the contrary, the artist quite mechanically attaches the short side of the bed to the ground surface line, while the long side does not touch it at all. The antic master solves the contradiction that arises between the three-dimensionality of the depicted object caused by the requirements of the principle of visualization of the narrative and the general planar nature of the composition, unlike the previous example, not by distorting the shape of the object. On the contrary, the artist utilizes the coloristic technique of local color patches which visually flattens the depiction of the bed. The volume of the object is guessed but not supported by treatment of light and shade. As a result, the problem is solved: the artist reproduces the three-dimensionality of the bed without violation the solidity of the sheet surface.

This way, the both variants of the solution of the described contradiction presuppose a certain "discontinuity", a violation of the unity of spatial logic within the composition. The artist makes a compromise with these distortions in order to comply with requirements of the most important principle of the visualization of narrative. Analyzing this heterogeneity of the space constructions of late antique miniatures one can recall the thought of E. Panofsky expressed in his article "Perspective as Symbolic Form" about the fundamental discontinuity, unsystematic nature of space in the ancient art ${ }^{13}$. The great German researcher wrote about the ancient compositions in which the illusion of depth was created. However, this principle seems to hold true for the tradition of roll illustration as well.

So, the cited examples of miniatures in rolls and codices allow us to speak about a specific type of space organization characteristic of the illustration of the "papyrus style". The close connection of the miniatures with the text characteristic of this type, on the one hand, determines the planar character of the images and their horizontal development resembling a text line. On the other hand, the necessity to the text in certain cases determines the need to convey the depth by arranging images into a sys

13 E. Panofsky, Perspective as Symbolic Form. Zone Books, New York, p. 42 . tem of spatial plans or by including three-dimensional elements in the composition that nevertheles does not violate the general planar nature of the illustration.

Analyzing spatial constructions in the book miniature of the era of the late Antiquity, one canno fail to mention such an important process, which takes place in the book art, as the gradual emancipation of the illustration from the text column. The system of roll illustrations transferred to the codex is being transformed. Increasing width of the tex column entails the increase of the size of the illus tration. Compositions that have previously existed separately are combined into one scene ${ }^{14}$, sometimes they were even arranged in several levels. The process of the emancipation of the image from the text is closely related to the development of space constructions. For instance, in a number of surviving manuscripts the artists combine two scenes located one above the other by widening of the ground surface line. A suitable example of such unification is the miniature of the folio $9 r$ (Fig. 3.) of the Vienna Genesis. In spite of a little bit mechanical character of the integration of the two scenes separated in time and space, we can note that the basic line turns here into a surface on which the personages are located. The next important step on the path of the emancipation of the image from the text is the separation of the image with a frame. This turn the illustration into a detached space free of the dominance of the sheet plane, which visually flatens the image.

Subsequent to this important step is a pictorial treatment of the background. It is important to note that, as Kurt Weitzmann mentioned, this background is treated in a rather planar manner ${ }^{15}$. The illusion of space is created by adding (sometimes quite "mechanically", in the expression of Weitzmann) to the site a flat backdrop which depicts a part of the environment remote from the viewer in a rather abstract manner. Thus, the action takes place in a narrow strip of the spatial layer, on a kind of stage "gripped" between the transparent "screen" of the sheet surface and the flat background reminiscent of theater scenery.

A good example of such an organization of space is the miniatures of the Ambrosian Iliad (late 5th -

14 K. Weitzmann, Illustraitions in Roll and Codex, Princeton University Press, 1970, p. 84.

K. Weitzmann, 1 llustraitions
versity Press, 1970, p. 99. 




III. 3. Wien, österreichische Nationalbibliothek, Cod. Theol. gr. 31 .
Miniature painting of folio $9 \mathrm{r}$ with a graphic scheme of spatial organization.

early 6 th century $)^{16}$. Folio $42 v$ represents the sacrifice of Achilles (Fig. 4, 5.). The action takes place on the ocher-yellow strip of land. The blue-sky field limits it from behind. This way, due to the separation of the image from the text with a frame, the artist gets the opportunity to form a spatial layer inside the composition. This spatial layer is rather narrow, it is "gripped" between the transparen "screen", which the frame creates, and the flat backdrop resembling a theatrical stage. The impression of the spatiality of the image arises due to the fact that the characters and the objects around them "break away" from the basic horizontal line and find themselves located on the ground surface. However, the ocher-yellow stripe, covered over with one color, by itself, out of connection with the images located on it does not create the impression of spatial dynamics. It is perceived as a foreshortened surface of the ground due to the fact that the position of the anatomically correctly depicted feet of Achilles corresponds to the perspective of the altar. Owing to these details the viewer's eye guesses the movement of the surface on which they are disposed. The fact that the altar is depicted in accordance with principles of axonometry also emphasizes the spatiality of the scene. Here, in contrast to the miniatures of the Vienna Genesis, the master draws

16 Milan, Biblioteca Ambrosiana, Cod. F205inf, Ilias Ambrosiana

all the corresponding facets of the object in parallel to each other, without any distortion. The entire scene is illuminated from a single source: the volume of the hero's figure, of the altar, of the trunks and the foliage of the two small trees next to the altar are conveyed by chiaroscuro. Accordingly, the master emphasizes the stability of their location on the plane by the shadows that they cast.

Such a system of the space organization of book illustrations as a narrow spatial layer will take on fundamental significance for the late antique miniatures in which artists will aspire to convey the illusion of depth. This system first appears at the turn of the 4 th and 5 th centuries ${ }^{17}$. This principle obtain its most eloquent artistic expression in two remarkable monuments which were presumably created in the same workshop - these are the Quedlinburg Itala fragments (early 5 th century) ${ }^{18}$ and the Vatican Virgil (late 4 th - early 5 th century) ${ }^{19}$. A distincanization feature of the miniatures of these magnificent manuscripts is that there is no clear boundary between the strip of the ground surface and the background. So, in the scene of Saul's sacrifice, presented on the folio 2 of the Quedlinburg Itala, the lower yellow-ocher band, on which

17 K. Weitzmann, Illustraitions in Roll and Codex, Princeton University Press, 1970, p.100

18 Staatsbibliothek zu Berlin, Cod. theol. lat. fol. 485. the action of the miniature takes place, is gradualy spilling over to the background. The artist forms it from several color stripes smoothly merging into each other. This technique allows the artist to create an effect resembling the impressionists' "aerial perspective". At the same time, the master does not convey the depth of the space in the proper sense of the word since the background does not contain any hint at the depiction of environment, object contours or the horizon line. Because of this, it is rather difficult to say that the antique artist overcomes the planar solution of the background. Rather the latter resembles picturesque scenery which conveys spatial dynamics into the depth but still remains flat itself.

It should be noted that the authors of the illusionistic miniatures of the two magnificent manuscripts solved very diverse spatial problems. The series of the miniatures of the Vatican Virgil contains the representations of interiors as, for instance, the scene of Dido's death on the folio 41r. In the interior compositions (folio 40r and 41r) the artist depicts the ceiling in a characteristic "antique" perspective: the parallel straight lines converge in respect to each other, but do not go to a single vanishing point ${ }^{20}$. The same manuscript contains examples of landscapes with panoramic views as in the miniature on the folio 42r. Nevertheless, in all these cases the same spatial system remains: the action unfolds between the screen of the parchment sheet and the flat background.

All in all we can conclude that in the illuminated manuscripts of the end of the Roman Empire there are several instances of creating the illusion of space. The authors of these monuments of the book painting convey the space in accordance with the certain principles. At the same time, these principles are much less rigid than mathematical constructions of the Renaissance perspective. In the late antique miniatures there is no mathematically verified perspective grid which is "superimposed" on the scene and subordinates all elem The antic masters create the illusion of a spatial layer by utilizing several artistic techniques aimed rather at creating the illusion of three-dimensionality of the figures of characters and objects around them than at forming of a rigidly structured space In this regard, one cannot fail to recall once again the thought of Erwin Panofsky about the unsystem

20 E. Panofsky, Perspective as Symbolic Form. Zone Books, New York, p. 38 and late atic nature of space organization in the ancient art. The German researcher notes that there are constant "glitches" in the illusionistic antique compositions. This "discontinuity" of space is connected according to Panofsky, with the fact that the classical art of Antiquity, which laid the foundation no only for the late antique but also the medieval art was "a purely corporeal art ${ }^{21 . "}$ "The era of Hellenism according to Panofsky, expanded the artist's field of vision. The masters began to depict, in addition to the objects, "the surrounding space which unified them". Nevertheless, "the artistic imagination remains attached to individual objects, to such an extent that space was still perceived not as something that could embrace and dissolve the opposition between bodies and nonbodies, but only as that which remains, so to speak, between the bodies ${ }^{22 . "}$

Thus, in the ancient art, the emphasis is shifted to the depiction of the body. Indeed, in the above examples of the illustrations of the late Roman manuscripts, the illusion of space arises due to utilization of certain artistic techniques aimed mainly at the depiction of bodies, objects, the conveying thei positions relative to each other rather than their environment. This principle of aspective, judging by the surviving ancient Roman copies, was characteristic of the monumental painting of the Ancient Greece, but in the book miniatures of the late Antiquity it undergoes its own changes. The focus on the depiction of the image of an individual object the "bodies", makes an impact upon the characte of space constructions. For instance, the arrangement of figures in the spatial layer does not presup poses a strictly defined spatial module which could determine the diminution of the objects while mov ing away from the foreground into the depth of the composition. The size of the objects often does not decrease at all. In this way, in some miniatures of the Vatican Virgil, when it is necessary to show a wide panorama of a city or an entire island as, for example, on the folio $27 r$, the artist expands the plane of the "scene" to the upper edge of the composition. Seemingly, it could be expected that the expansion of the surface plane will make it possible to con vey the active space dynamics into depth. However, the ancient master avoids visual deepening of the space and aspires to maintain a single scale of the depicted objects. The artist represents houses

21 E. Panofsky, Perspective as Symbolic Form. Zone Books, New York, p.
Ibid. 


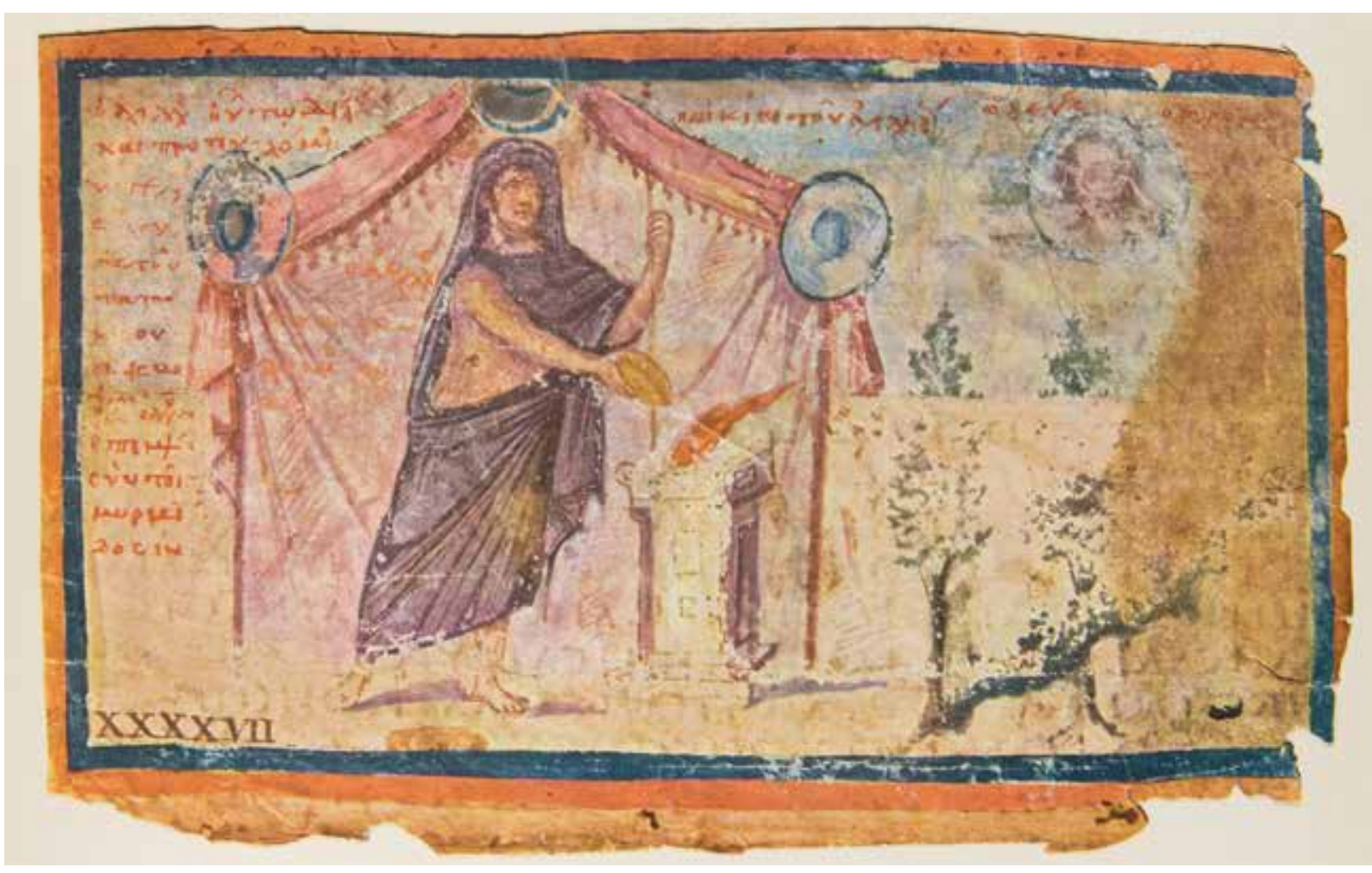

11. 4. Milan, Biblioteca Ambrosiana, Cod. F205inf, llias Ambrosiana, folio 42 v

and walls placed in the upper part of the image and, sional images occurs repeatedly: we may recall the apparently, quite distant from the imaginary viewer on the same scale as those located in the foreground. Thus, the enlargement of the spatial layer does not solve the problem of its depth, it still remains to be narrow.

The concentration of the artist's attention on the depiction of individual objects is closely related to the subjectivity of space constructions which E. Panofsky mentions. In some miniatures of the Vatican Virgil, this subjectivity results in the fact that the certain elements of the compositions are depicted out of the general spatial logic of the miniature painting. A number of Russian researchers consider such "distortions" of images in connection with a desire to depict an object from the most favorable point of view so that to convey the information about it as fully as possible ${ }^{23}$. Indeed, the composition on the folio $17 r$ depicts the sea, the coastline and the isand in the background from a higher point of view one may say, from the top down. At the same time, the master depicts the temple on the island frontally as well as the trees behind it which he arranges on the upper part of the plane outline of the island. The similar combination of planar and three-dimen23 P. Florensky, Works in four volumes, V.3. - M ., 2000, Reverse perspective, pp. 46 - 98., B.V. Rauschenbach Spatial construcUspensky Semiotics of Art — M : School "Languages of Russian Culture", July 1995. miniature of the folio $6 r$ where the lake depicted in a flatly manner destroys the three-dimensional spatial logic of the miniature painting. Also, the subjectivity of space constructions becomes apparen in violations of the unity of scale of the compositional elements. For instance, in the miniature of the folio 19r, the figures of the warriors are disproportionately large in comparison not only with the city walls but also with the Trojan horse.

In this way, the system of space construction elaborated in the late antique illusionistic miniatures was quite flexible and presupposed the certain subjectivity. This subjectivity was gradually increasing since the middle of the 5 th century ${ }^{24}$. Since that time, in the book miniature, a gradual transition had begun from the interpretation of the image as an illusion of tree-dimensional reality created on a plane surface to the image as a pictorial unit which integrates a whole complex of knowledge about the object. In other words, the image summarizes the author's visual impressions separated in time and space. Ac cordingly, the image often combines different points the treatment of light and shade, the shadows cast the correlation between the positions of the figure's 24 K. Weitzmann, Illustraitions in Roll and Codex, Princeton University Press, 1970., p. 56 of view. This makes the depiction more plane. The artistic means aimed at volume conveying such as

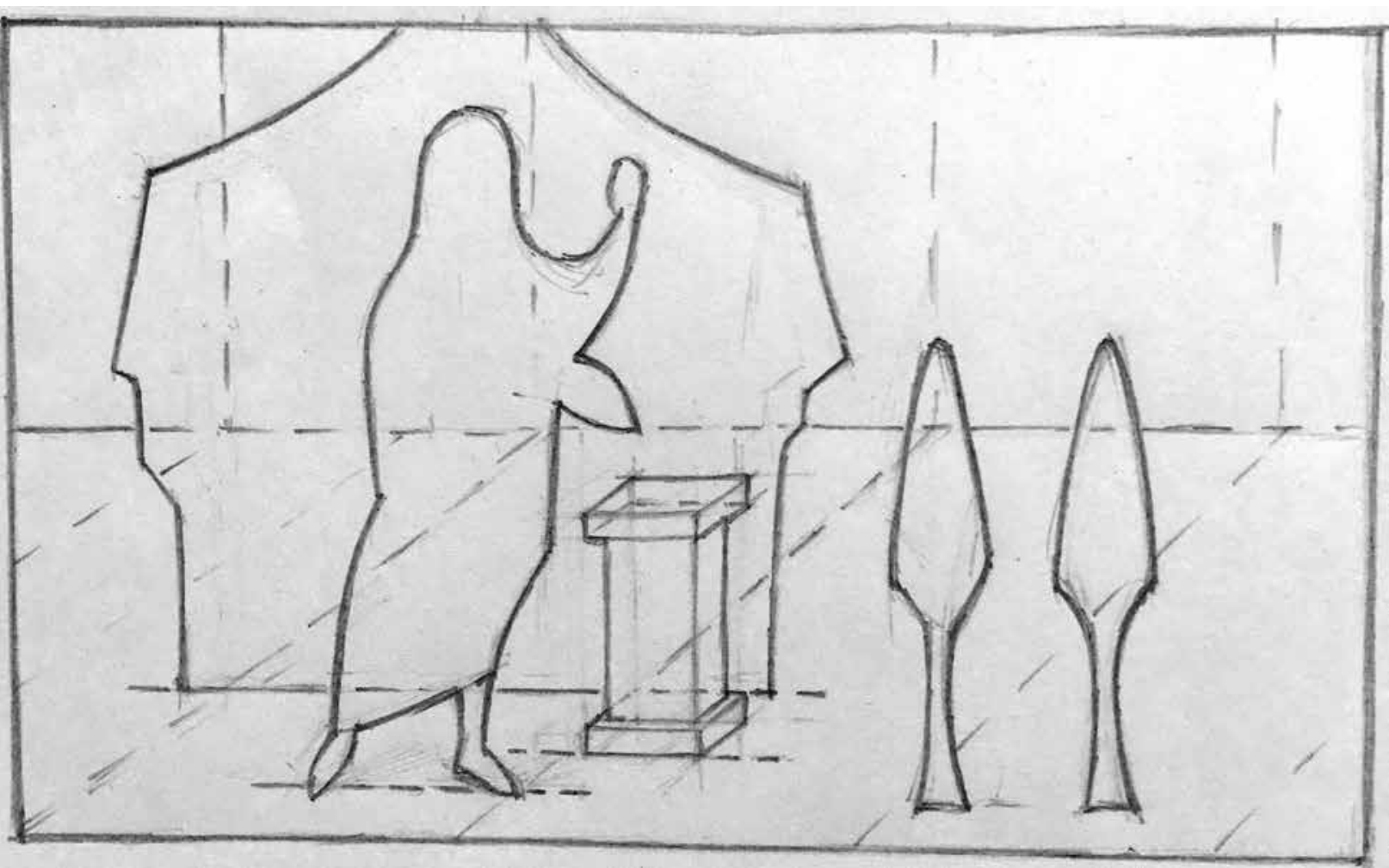

IIl. 5. llias Ambrosiana, folio $42 \mathrm{v}$, graphic scheme of spatial organization.

feet and the perspective of the surface plane - all with the scene of Dido and Aeneas at a feast from these techniques turn out to be unnecessary and the Roman Virgil25, a manuscript from the middle gradually disappear. The outline takes on the spe- of the 5th century in which the features of the trancial significance as a unifying principle combining sition to the new pictorial system appeared for the different perspectives together in one image. The first time. Depicting the central characters of the minapproach to the image as a specific "sum of knowl- iature, the artist combines several different perspecedge" about the object presupposes not only the tives. The author represents the table from a high quest of the most suitable perspective for each of point of view, while the torsos of the characters, on its part but also the facial expressions which most the contrary, are depicted from the front The mascharacteristically reflect the conception of the char- ter represents the faces en face as well, most likely, acter as a whole person, of its inner world. Thus, to create an image of more expressiveness. The authe principle of summarizing visual impressions al- thor aspires to put emphasis on the most significant lows the viewer to receive much more information parts of the body and therefore disproportionally enabout the object than the reproduction of a single larges the personages' heads, eyes, torsos. The desire impression of the object at a given point in time on to convey the most important information about the the pictorial plane. So, in this sense, we can say that depicted body sometimes leads to a kind of "omisthe logic of the development of ancient art is not sion": picturing the left character's arm reaching out interrupted. As with the ancient illusionistic paint- towards the table the master depicts just the hand ing, the artist focuses on the object. The emphasis is and the forearm. Apparently, for the artist it seems to shifted from the subjec

object to a greater objectivity, the desire to depict action. Therefore, the shoulder is left out by the artobject as the artist knows it, and not as it is seen. We can observe the described process on the example of a number of monuments of the transitional period. The development seemingly progressed gradually, at different rates in different regions. It should be noted that the changes affected firstly the manner of the miniature characters' representation. For instance, we may recall the miniature painting ist as an uninformative detail which could come into conflict with the rhythmic unity of the whole miniature painting. These distortions lead to the visual flattening of the images. The manner of the depiction of the characters' garments as color patches covered over with a uniform tint and a linear rhythm of

25 Biblioteca Apostolica Vaticana, Vat.lat.3867. 
folds superimposed above correspond with the planar nature of the images of the illustration.

However, it is important to note that the described "distortions" in the characters' representation do not destroy the basis of the spatial layer system in the composition of the Roman Virgil. The action takes place on the narrow horizontal strip limited by the vertical plane of the wall. Due to the vertical displacement of the compositional elements, a system of plans is created: the figures of the slaves are located closer, in the foreground while the table and the figures of the main characters are disposed in the background. In addition, the images of the servants overlap the depiction of the bed. This feature indicates that the slaves are closer to the position of imaginary viewer, and this, in its turn, visually moves them out to the fore. Thus, we can say that a spatial layer is formed in the miniature of the Roman Virgil. However, the tendency to summarize several visual impressions and the general flattening of images lead to the fact that the sensation of spatial dynamics is significantly weakened.

A significant change in the space organization of book miniatures is the unification of the "stage where the action takes place and the background. In this way, in the Rabbula Gospels (6th century) ${ }^{26}$ on the folio $14 r$ the evangelists surrounding Christ seated on the throne are depicted on a green field which covers the entire miniature likewise a carpet. The artist gives no hint at the border between the horizontal strip of a "stage" and the background. At the same time, the artist implies the opposition between the foreshortened ground surface and the vertical plane of the backdrop indicating it by some methods and details. First of all, the evangelists figures are anatomically proportional, they are illuminated from one point (the shadows cast to the right side of each figure). Then, the characters' feet "stand" on the same plane, that is, they are rotated accordingly to each other in such way that the plane on which the evangelists are located is visually guessed. In addition, the master also utilizes the technique of vertical displacement: the two figures located below are seemingly closer to the imaginary spectator than those that are placed higher. Thus, the author creates an impression that the foreshortened ground surface gradually "flows" into the vertical background and, consequently, forms a kind of a spatial layer in the miniature painting

26 Firenze, Biblioteca Medicea Laurenziana, cod. Plut. I, 56.
At the same time, in another composition of the Rabbula Gospels (folio 1r), the scene of Pentecost the feeling of spatial dynamics within the miniature painting entirely disappears, though the master represents the characters against the same background of green grass. The major cause of the disappearance of the spatial layer in the miniature painting is that the author combines in the composition two different points of view on the scene On the on hand, the master disposes the figures of the apostles along the edge of a circular field which seems to be a kind of piece of ground in the centre of a green field. This creates the impression that we perceive the scene from a high point of view. On the other hand, the figures of the apostles themselves are depicted strictly frontally. All in all, the application of the principle of summarizing visual impression leads to the fact that the characters' figures seem to be "cut out" and glued to the parchment sheet. The depiction of the apostles without any treatment of light and shade, in a planar manner as well as a thick contour line around the images also corresponds with this effect. Certainly, it should be noted that there are certain spatial relationships between the characters of the miniature painting. However they are rather guessed than depicted. The figures of the apostles located below overlap the figures located slightly higher, and this way come to the fore of the miniature

Thus, we may say that in the late antique illustrations of the codices separated from the text by the frame a return to the system of spatial plans has been carried out. In a sense, this process might be considered in context of the general trend in the late antique art noted by Panofsky, the focus on the object depiction sometimes at the expense of the unity of spatial logic. Accordingly, this tendency of the subjective interpretation of images leads to an increase of the subjectivity of space constructions and then to the abandonment of the task of creating the illusion of space at all. To convey spatial relationships between images, it is enough to designate these relationships, point them out but not to represent. To achieve these objectivities the artistic means indicating spatial relations in roll illustrations, the method of "superimposition" and the technique of "vertical displacement", are quite sufficient.

Here are some instances of the late antique miniature paintings organized as a system of spatial plans. Such spatial organization is carried out in on of the small miniatures dedicated to the Passion of

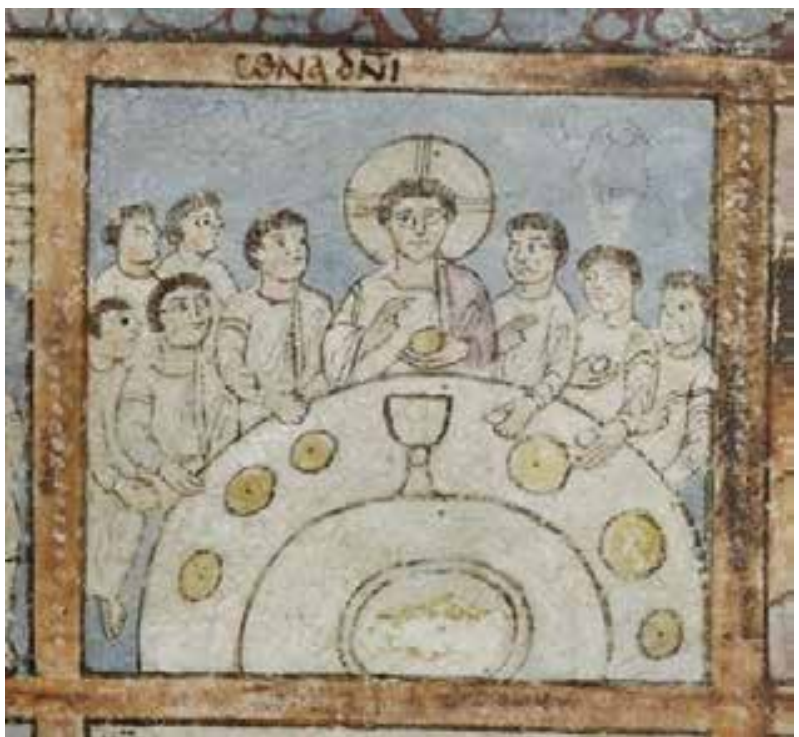

III. 6. Cambrdige, Corpus Christi College, Lib. MS. 286,

Christ on the folio 125r of the St. Augustine Gospels (6th century) ${ }^{27}$, namely the scene of the Las Supper (Fig. 6.). The artist reproduces Christ and the apostles seated at the table. The master combines several perspectives: he represents the characters' figures frontally while the table is depicted from a high point of view. At the same time, the autho creates a system of spatial plans: the round table overlaps the figures of the characters and this way comes to the fore (Fig. 7.). In turn, the master displaces the apostles in two ranks, so that the front figures cover the images of those sitting behind and, therefore, remove them into the background. Another example of a monument, whose miniatures are built in accordance with the principle of spatial plans, is the Ashburnham Pentateuch (6th early 7 th century ${ }^{28}$. In the upper part of the miniature of the folio $65 r$ "Egyptians mourning their first-borns" the characters depicted in planar, rather abstract manner seem to be hovering against the background. The figures have no connection with the plane; they seem to be "cut out" and superimposed on the architectural background that fills the entire

27 Cambrdige, Corpus Christi College, Lib. MS. 286

28 Bibliothèque nationale de France, MS nour. acq lat 2334

REFERENCES:

1. Zhogin, L.F. 1970. The language of the painting, Moscow 5. Grabar, A., Nordenfalk, C. 1957. Le haut moyen age, du 2. Rauschenbach, B.V. 1975. Spatial constructions in ancient Russian painting, Moscow.

3. Uspensky, B.A.1995. Semiotics of Art, Moscow

4. Florensky, P. 2000. Works in four volumes, vol. 3. Reverse perspective, Moscow, pp. 46-98.

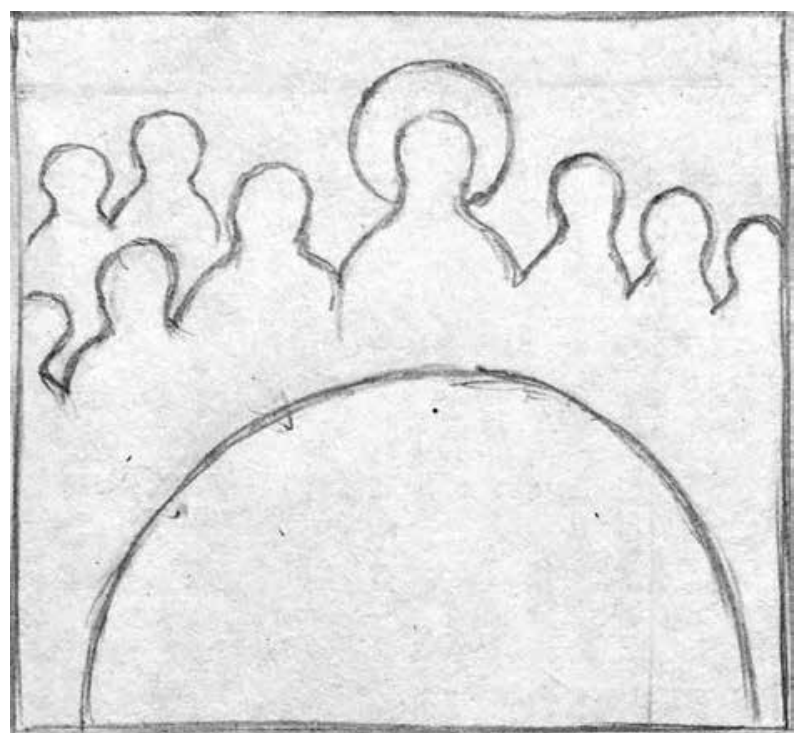

IIl. 7. St. Augustine Gospels, folio 125r, drawing.

miniature. Thus, the two plans are formed, the first where the action takes place, and the second which is an expanded architectural composition indicating the scene of the action. Such a system of severa separate spatial layers will be extremely importan for the medieval miniature painting. In particular, it will be in a demand in book illustrations of the Romanesque epoch which compositions form a complex, multi-stage system of spatial plans ${ }^{29}$.

To sum up, we can conclude that in the late antique book miniature three main types of space construction can be distinguished. Firstly, the tradition of roll illustrations presupposes a planar character of compositions which develop likewise a frieze along a horizontal line Secondly, the appearance of the frame made it possible to create compositions limited, on the one hand, by the plane of the sheet and, on the other, by a flat background. Thirdly, under the influence of the general trend of the late antic art, the miniatures separated from the text by a frame return to the organization of the composition as a system of spatial plans.

29 O. Pächt, Buchmalerei des Mittelalters: eine Einführung, Prestel-Verlag, 1984, S. 43. in which the action develops within a spatial layer
Weitzmann, K. 1970. Illustraitions in Roll and Codex, Princeton University Press, 1970.

Pächt, O. 1984. Buchmalerei des Mittelalters: eine Einfuhrung. Prestel-Verlag, p. 43. 
Михаил Сергеевич Банков

Аспирант Московской государственной художественно-промышленной академии им. С.Г. СТроганова Кафедра истории искусств и гуманитарных наук e-mail: bankoff3@yandex.ru Москва, Россия ORCID 0000-0003-2414-822

DOI: 10.36340/2071-6818-2021-17-4-29-48

\section{К ВОПРОСУ ОРГАНИЗАЦИИ ПРОСТРАНСТВА В КНИЖНОЙ МИНИАТЮРЕ ПОЗДНЕЙ АНТИЧНОСТИ И РАННЕГО СРЕДНЕВЕКОВЬЯ ( IV—VII ВВ.)}

Аннотация: В статье анализируются особенности построения пространства в иллюстрациях рукописей V-VII веков. Проблема передачи глубины на плоскости книжной страницы анализируется в контексте постепенного перехода от свитков к кодексам, который произошёл между II и V веками. Анализируя сохранившиеся фрагменты иллюстрированных свитков, автор выявляет характерные для них особенности организации пространства и рассматривает влияние традиции иллюстрирования свитков на развитие кодекса. Тем не менее именно миниатюры дошедших до нашего времени кодексов находятся в фокусе внимания автора Этапы развития организации текстового пространства, особенности взаимодействия текста и изобрантения о собенности взаимодействия текста и изображения в рукописях сопоставляются с принципами построним пространства в миниатюрах. В статье предпривремени памятники, рассмотреть развитие пространственных построений в период позднй Антостранранны постоенй в период поздней Античности и

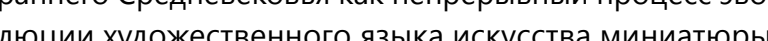
Автор предпоте что развитие пространствн

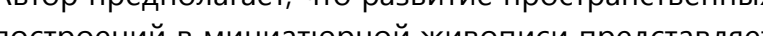
собой собой целостнй процесс, в котором каждый новый арсенал худож ствен и средств, необходим В Аля

решени стояии перед художникани задач. В соот-

Искусство переходного периода от поздней Античности к Средним векам - чрезвычайно важный этап в развитии европейской культуры. В это время закладываются основы средневекового искусства. Особое значение играет эта эпоха для искусства книжной миниатюры. В этот пери од происходит формирование кодекса, основополагающих принципов взаимодействия текста и изображения в пространстве книги. Развитие искусства книги в переходную эпоху делает осо- ветствии с данным подходом в статье анализируются не только композиции, в которых прослеживаетс пространственная иллюзия, но и миниатюры, носящие более плоскостной характер. В результате выявляются основные типы пространственных построений, характерных для всех сохранившихся памятников книжной миниатюры того времени. Для каждого типа формирования пространства автор выявляет базовые принципы, характерные для данного типа художественные приёмы, позволяющие мастеру передать ощущение глубины на плоскости страницы. Особое внимание уделяется автором сопоставлению иллюзионистических тенденций позднеантичной книжной миниатюре и «обратной перспективы», черты которой присутствуют в памятниках эпохи. Автор ставит под сомнение необходимость резкого противопоставления этих двух подходов к организации пространства в памятниках книжной миниатюры эпохи. В статье анализируются причины возникновения в миниатюрах позднеантичных и раннесредневековых рукописей подобтичнх и раннесредневековых рукописей подоб( важных для формиров

Ключевин стова: Пространственнtе построения,

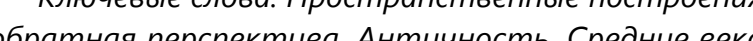
книжная миниатюра.

бенно значимым вопрос об организации пространства в позднеантичных миниатюрах. Это вопрос освещался в исследованиях весьма авторитетных учёных. Тем не менее исследование пространственных построений в памятниках книжного искусства долгое время носило внбороч. были, преимущественно, миниатюры, наследу ющие традиции античной иллюзионистическо живописи. Напротив, принципы организации про- странства в композициях, в которых отсутствует иллюзия глубины, оставались долгое время «з скобками» искусствоведческих исследований. Исследования пространственных построений средневековой живописи XX столетия, в которые был внесен существенный вклад отечественных учёных, позволяют, опираясь на сохранившиеся памятники, наметить единую линию развития пространственных построений в позднеантичной книжной миниатюре и выделить основные типы организации пространства в иллюстрациях Именно эту цель преследует настоящая статья.

Взлёт искусства книжной миниатюры в позднеантичный период был связан, по мнению исследователей с технически и новые возможности для художников ${ }^{1}$. Речь идёт о постепенном переходе от папирусного свитка к пергаментному кодексу, который осуществился между II и $\vee$ веками нашей эры². Тем не менее до III-IV веков папирусные свитки оставались основными для рукописных текстов. Известно, что в античности существовала традиция иллюстрирования свитков, восходящая к египетским рукописям. ${ }^{3}$ Сохранившиеся фрагменты папирусов С миниатюрами, самый ранний из которых относится ко II веку до нашей эры ${ }^{4}$, позволяют утверждать, что иллюстрации античных свитков располагались непосредственно внутри узких текстовых колонок. Миниатюры буквально прерывают блок текста $и$ предлагают визуальный эквивалент той части повествования, рядом с которой располагается иллюстрация ${ }^{5}$. Тип композиций иллюстрированных свитков долгое время воспроизводился и в кодексах и существенным образом повлиял на развитие искусства оформления книги. Данному типу миниатюр соответствуют определенные особенности организации пространства.

Важной характерной чертой композиций иллюстрированных свитков является то, что образы расположены непосредственно на поверхности листа папируса. Действие, таким образом, раз-

1 Grabar Andre, Nordenfalk Carl. Le haut moyen age, du quaGieme au onzieme siecle. Geneve: Skira, 1957; Weitzmann K. 1970. C. 57

2 Weitzmann K. Illustraitions in Roll and Codex. Princeton University Press, 1970. C. 69-70.

Там же, С. 49 .

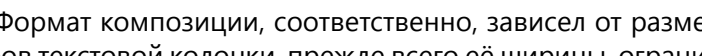
чивающей поле изображения слева и и справа. вивается вне какой-либо пространственной сре ды. Вероятнее всего, это связано с технической особенностью носителя: постоянная необходимость сворачивать папирус неминуемо привела бы к порче изображения и, в конечном итоге, к его разрушению ${ }^{6}$. Одновременно расположение изображений, как и текстовых элементов, непо средственно на плоскости листа усиливает связ текста и миниатюр. Подчеркивает связь текста и изображения то, что действие развивается по горизонтали слева направо. В фокусе внимания художника находятся образы персонажей, действующих лиц, которые, подобно словам в тексте, складываются в невербальное повествование.

Расположение в едином поле изображений и текста влечёт за собой то, что поверхность листа как бы подчиняет себе изображение, которое носит плоскостной характер. Такое отношение к художественной форме является противоположным по отношению к развитию иллюзионистических тенденций в монументальной фресковой живописи7 ${ }^{7}$ Можно предположить, что тесная связь образа с текстом в иллюстрации свитков требовала, чтобы характер изображения «поддержи вал» монолитность поверхности листа. Понятно и отсутствие светотеневой проработки объёмов, которая бы нарушала целостность поверхности листа, «продавливая» и ломая её. Напротив, плоскостной характер образов в полной мере соответствовал требованию сохранения и утверждения плоскости листа.

Заметим, однако, что плоскостной характер образов и отсутствие пространственно-предмет ной среды не означает отсутствия в композици ях определённых пространственных отношений. Так, весьма важным средством передачи пространства в иллюстрациях свитков является метод «наложения» одного изображения на другое Показывая, что одна фигура перекрывает другую, художник обозначает присутствие в композиции нескольких пространственных планов. Наглядным примером может быть фрагмент миниатюры с группой всадников из Коллекции Джонсона (IV—V вв.). Здесь пространственные планы формируются благодаря тому, что всадники, расположенные ниже на листе папируса, перекрывают фигуры других, расположенных выше.

6 Weitzmann K. Illustraitions in Roll and Codex. Princeton University Press, 1970, C. 52-53. Weitzmann K. Illustraitions in Roll and Codex. Princeton University Press, 1970. C. 53. 
Метод наложения тесно связан с другим приёмом, который можно обозначить как метод «сме щения по вертикали». Суть приёма состоит в том что плоскостные образы, соответствующие друг другу по масштабу, немного смещаются относительно друг друга по вертикали. Как известно, объект, расположенный ближе к человеку, на сетчатке глаза оказывается ниже, чем такой же объект, находящийся дальше. Наблюдательность античного художника позволяет использовать это смещение образов по вертикали на плоскости листа как художественный приём, указывающий на пространственные отношения между изображёнными фигурами. В качестве примера использования этого метода можно упомянуть иллюстрированный фрагмент пергаментного свитка из Баварской национальной библиотеки ${ }^{8}$ (IV в.) По мнению Вайцмана, сцена является иллюстрацией к Илиаде, и изображает момент, когда Талфибий и Эврибат уводят Бризеиду от Ахилла. Художник располагает одного из сопровождающих мужчин ниже, чем двух других персонажей. Таким образом, один персонаж оказывается на переднем плане, в то время как остальные смещаются на второй план, создавая иллюзию глубины пространства.

Приведённые примеры позволяют говорить о оом, что в античных иллюстрациях свитков с помощью указанных художественных приёмов выстраивались специфические пространственные отношения: система взаимного расположения плоскостно решённых образов без построения пространства, но создающая за счёт пространственных планов представление о его глубине. Эта система будет использоваться и в дальнейшем в дошедших до нас позднеантичных кодексах, в которых художники воспроизводят ту же схему построения пространства.

Это можно проследить на примере ряда дошедших до нас рукописей. Одной из них является так называемый Синопский кодекс из Национальной библиотеки Франции ${ }^{9}$ (VI в.). На листе 29 представлена сцена исцеления Христом слепого. Как и в иллюстрированных свитках, действие развивается вдоль плоскости листа по горизонтальной оси. Фигуры персонажей объединяет едва заметная тонкая линия позёма. Образы представлены в плоскостной манере: ноги, стопы персо-

8 Bauerische Staatsbibliotek. Munchen, gr. mon. 138 suppl. grec 1286, I. нажей, опирающиеся на условную линию позёма, изображены в профиль, в то время как торс развёрнуты в фас. Тем не менее в композиции ринилары как и во фрагментах иллюстрированных свитков, присутствует указание на пространственные отношения между персонажами Здесь также используется приём «наложения»; фигура одного слепого перекрывает фигуру дру гого, один из учеников скрывается за другими разом, в миниатюре Синопского кодекса воспроизводится система пространственных «планов», характерная для иллюстраций в свитках

Важной тенденцией миниатюр, воспроизводящих тип иллюстраций свитков в кодексах, являетс появление в них и развитие позёма, объединяющего фигуры персонажей. Так, если в Синопском кодексе позём представляет собой отвлечённую линию, то в сцене воскрешения Лазаря миниатюры листа 1 Евангелия из Россано ${ }^{10}$ (VI в.) линия позёма носит значительно менее отвлечённый характер. Художник передаёт неровности земли, где изгибающаяся линия позёма переходит в изображение скалы и гробницы. Таким образом, постепенно формируется пока ещё условный пространственный слой, намечающий единое пространство окружающей среды ${ }^{11}$. Ещё более заметна эта тенденция в нижнем регистре миниатюры листа 16 того же Евангелия из Россано, где линия позёма приоб ретает очертания холмистой поверхности земли представленной как будто «в разрезе».

Тем не менее, необходимо отметить, что на данном этапе позём остаётся только знаком плоскости. Подобно горизонтальной линии, которую писцы чертили для того, чтобы сохранить единство строчки, линия позёма объединяет образ композиции в единый рассказ. В центре внимания позднеантичного художника является на глядность этого рассказа, сообщение зрителю необходимой для понимания развития сюжет информации о действующих лицах и окружающих их предметах. В определённых случаях принци наглядности повествования требует от мастера передачи глубины в изображении отдельного объекта, которым чаще всего выступает архитек-

10 Museo Diocesano di Arte Sacra di Rossano, Codex Rossanensis

11 Ещё более явным становится эта тенденция в нижнем ре гистре миниатюры на странице 16 того же Евангелия и Россано, где линия плоскости земли приобретает очерта-
ния небольшого холма, который мы видим словно «в разрезе тура. Таким образом, возникает противоречие между объединяющей образы горизонтальной линией позёма и общим плоскостным характером композиции, с одной стороны, и требованиями принципа наглядности повествования, с другой. Мастера оказываются в таких случаях перед сложной задачей совмещения двух этих противоречивых моментов.

Один из вариантов решения этой задачи соединение в изображении объекта нескольких различных ракурсов. Так, в миниатюре листа 13 Евангелия из Россано (рис. 1, 2.), посвящённой исцелению слепого, изображенная в правой части «купальня» представлена как параллелепипед. Художник показывает верхнюю часть купели с более высокой точки зрения, изображая её в системе аксонометрии. Это необходимо, по всей видимости, для того, чтобы показать гладь воды и объём купели, необходимый для понимания её назначения. В то же время все остальные образь композиции подчинены принципу плоскостности развиваются вдоль горизонтальной линии, обозначающей поверхность земли. Соответственно для того, чтобы передать устойчивость купели художник изображает нижнюю часть плоскостно, для чего непропорционально, как кажется, удлиняет её вертикальную сторону. Таким образом, в одном объекте за счёт комбинации нескольких точек зрения, передается объём, глубина и, одновременно, все образы композиционно выстраиваются на одной горизонтали. Плоскость листа не нарушается. Такие приёмы композиционного построения встречаются всё чаще с VI века.

Другой вариант - присоединение трёхмерного изображения к линии позёма без искажений и уплощение образа на уровне колористического решения. В качестве примера можно вспомнить миниатюру 4v Венской Книги Бытия ${ }^{12}$ (I пол. VI века), посвящённую обещанию, данному Богом Аврааму о его многочисленном потомстве. В левой части верхнего регистра композиции представлен спящий на ложе Авраам. Ложе изображено художником в системе аксонометрии без искажений. Боковая плоскость параллелепипеда развивается по диагонали, дальний край смещён вверх по вертикали. Естественное расположение предмета требует плоскости поверхности, соответственно уходящей в глубину. Напротив, художник достаточно механически присоединяет торцевую сто-

12 Wien, Österreichische Nationalbibliothek, Cod. Theol. gr. 31 рону ложа к горизонтальной линии позёма, в то время как её длинная сторона оказывается не связанной с плоскостью. Возникшее противоречие между трехмерностью изображённого предмета обусловленной принципом наглядности, и общим плоскостным характером композиции решаетс художником, в отличие от предыдущего приме ра, не за счёт искажения формы предмета путём суммирования зрительных впечатлений а за счёт «уплощения» в изображении кровати и колори стического решения локальными пятнами. Объём предмета угадывается, но не поддерживается светотеневым решением. В результате задача решена: художник передал трёхмерность ложа и не нарушил монолитности плоскости листа пергамента.

Таким образом, оба варианта решения описанного противоречия предполагают известную «разорванность», нарушение единства пространственной логики внутри композиций. Мастер идёт на эти искажения для того, чтобы соответствовать важнейшему принципу наглядности повествования. Анализируя такую гетерогенность пространства позднеантичных миниатюр, можно вспомнить мысль Э. Панофски, высказанную в его статье «Перспектива как «символическая форма», о принципиальной разорванности, несистематичности пространства в античном искусстве ${ }^{13}$. Великий немецкий исследователь писал об античных композициях, в которых формиру ется иллюзия глубины пространства. Тем не менее представляется, что этот принцип актуален и для традиции свитковой иллюстрации.

Итак, приведённые примеры миниатюр в свит ках и кодексах позволяют говорить о специфическом типе организации пространства, характерном для традиции иллюстрированных свитков. Тесная связь миниатюр данного типа с текстом с одной стороны, определяет плоскостной характер образов и их развитие по горизонтали наподобие текстовой строки. С другой стороны, необходимость создания максимально точного изобразительного эквивалента тексту определяет необходимость ряде случаев передачи глубины путём выстраи вания плоскостных образов в систему пространственных планов или включения в композицию элементов трёхмерного изображения, не нарушающих плоскостного характера композиций.

13 Панофский Э. Перспектива как «символическая форма Готическая архите
сика, 2004. С. 48. 
Анализируя пространственные построения в книжной миниатюре эпохи поздней античности, нельзя не упомянуть о таком важнейшем процессе, как постепенная эмансипация изображения от текстовой колонки. Система иллюстраций свитка, перенесённая в кодекс, трансформируется. Увеличение размера текстового блока влечёт за собой увеличение увеличения размера иллюстрации. Композиции, существовавшие ранее отдельно, соединяются в одну ${ }^{14}$, иногда располагаются в несколько уровней. Процесс отделения изображения от текста тесно связан с развити ем пространственных построений. Так, в отдельных памятниках две разнесённые во времени и пространстве сцены, расположенные одна над другой, соединяются путём расширения позёма. Примером такого соединения может служить ми ниатюра листа 9r (рис. 3.) Венской Книги Бытия. Несмотря на несколько механический характер соединения двух сцен, нельзя не отметить, что условная линия позёма превращается в единую плоскость поверхности земли, на которой располагаются персонажи. Следующим важным этапом на пути эмансипации изображения от текста является отделение образа рамкой. Выделение иллюстрации в отдельное пространство освобождае её от доминирования плоскости листа, зрительно уплощающей изображение. Вслед за этим важным шагом следует живописное решение фона. Важно отметить, что, как заметил Курт Вайцман этот фон трактуется достаточно плоскостно ${ }^{15}$. Coздание иллюзии пространства происходит путём добавления (порой «несколько механического», по выражению Вайцмана) к площадке позёма плоского задника, который достаточно условно изображает удалённую от зрителя часть среды. Таким образом, действие происходит в узкой полосе пространственного слоя, на своего рода сцене, «зажатой» между прозрачным «экраном» поверхности листа и плоским фоном, напоминающим театральные декорации.

Примером такой организации пространства являются миниатюры Амброзианской Илиады (кон. V - нач. VI в.). На листе $42 \mathrm{v}$ представлено жертвоприношение Ахилла (рис. 4, 5). Действие разворачивается на вытянутой по горизонтали охристо-жёлтой полосе земли Сзади оно огра14 Weitzmann K. Illustraitions in Roll and Codex. Princeton University Press, 1970. C. 84

Weitzmann K. Illustraitions in Roll and Codex. Princeton Uni-

16 Mersity Press, 1970. C. 99. поверхности земли и фоном отсутствует чёткая граница. Так, в сцене жертвоприношения Саула, представленной на листе 2 Кведлинбургской Италы, нижняя жёлто-охристая полоса, на которой разворачивается действие миниатюры, плавно соединяется с фоном. Задний план формируется художником из нескольких плавно перетекающих друг в друга цветовых полос. Этот приём позволяет художнику создать ощущение плавно уходящего вдаль пространства, в то же время не создавая понимания его глубины, так как задний план не содержит в себе никакого намёка на предметную среду, очертаний предметов или линии горизонта. Из-за этого достаточно сложно говорить о том, что античный художник преодолевает плоскостное решение фона, скорее фон миниатюры напоминает живописные декорации, на которых изображено уходящее вдаль пространство, при том, что сами декорации остаются плоскими.

Необходимо отметить, что авторы иллюзионистических миниатюр двух великолепных манускриптов решали весьма разнообразные пространственные задачи. В миниатюрах Ватиканского Вергилия присутствуют изображения интерьеров, как, например, в сцене смерти Дидоны на листе 41r. В интерьерных сценах на листах 40r и 41r художник изображает потолок в характерной «античной» перспективе ${ }^{20}$ : параллельные прямые сходятся относительно друг друга, но не идут в единую точку схода. В той же рукописи есть примеры пейзажей с панорамным обзором, как в миниатюре на листе 42r. Тем не менее во всех этих случаях сохраняется та же система: действие разворачивается между экраном листа и плоским фоном.

Таким образом, можно заключить, что в мини атюрах рукописей, созданных на излёте существования Римской империи, присутствуют примерь создания иллюзии пространства в соответствии с определёнными принципами. В то же время эти принципы значительно менее жёсткие, чем в математически выстроенной ренессансной перспективе. В позднеантичных миниатюрах нет математически выверенной перспективной сетки, которая «накладывается» на изображение и подчиняет себе все элементы композиции. Иллюзия пространственного слоя формируется с помощью

20 Панофский Э. Перспектива как «символическая форма». классика, 2004. С. 50. ряда художественных приёмов, нацеленных скорее на создание иллюзии объёмности фигур персонажей и окружающих их предметов, нежели на формирование жёстко структурированного пространства. В этой связи нельзя не вспомнить ещё раз мысль Эрвина Панофски о несистема тичности пространства в античном искусстве. Немецкий исследователь отмечает, что в иллюзионистических античных композициях присутствуют постоянные «сбои». Эта «разорванность пространства связана, по мысли Панофски, с тем, что классическое искусство Античности, заложившее фундамент не только для позднеантичного, но и средневекового искусства, было «искусством чистой телесности» ${ }^{21}$. Эпоха эллинизма, по мыс ли Панофски, расширила поле зрения художника Мастера начинают изображать помимо предметов «окружающее и объединяющее их пространство». Тем не менее «художественное мышление всё ещё настолько привязано к отдельно взятым предметам, что пространство воспринимается не как нечто обеспечивающее и подчёркивающее различие между телом и нетелом, но до некоторой степени лишь как то, что остаётся в промежутке между телами ${ }^{22}$,.

Таким образом, в античном искусстве акцент смещён на изображение тела. Действительно, в приведённых выше примерах миниатюр позднеримских рукописей иллюзия пространства возникает благодаря определённым художественным приёмам, направленным в большей степени на изображение тел, объектов, передачу их взаимного расположения, нежели окружающей их среды. Этот принцип аспективы, судя по сохранившимся древнеримским копиям, был характерен для монументальной живописи Древней Греции, однако в миниатюрной живописи поздней Античности он претерпевает свои изменения. Фокус внимания на изображение отдельных объектов, «тел», отражается на характере передачи пространства. Здесь взаимное расположение фигур в пространстве не подчинено строго определённому модулю. Соответственно, по мере удаления от переднего плана миниатюры в глубину изображения, размеры объектов часто не уменьшаются. Так, в некоторых миниатюрах Ватиканского Вергилия, когда необходимо было

21 Панофский Э. Перспектива как «символическая форма» Готическая архитектура и схоластика. Спб, Азбука-классика, 22 TaM жe, c. 48
17 Weitzmann K. Illustraitions in Roll and Codex. Princetol
versity Press, 1970 . C. 100. .
18 Staatsbibliothek zu Berlin, Cod. theol. lat. fol. 485.
19 Biblioteca Apostolica Vaticana, Vat. lat. 3225. 
показать широкую панораму города или целого острова, как, например, на листе $27 r$, художник расширяет плоскость «сцены» до верхнего края листа. Казалось бы, можно ожидать, что расши рение плоскости поверхности позволит передать активное развитие пространства в глубину, однако античный мастер избегает углубления пространства и стремится сохранить единый масштаб изображаемых объектов. Дома и стены, расположенные в верхней части изображения и, по всей видимости, достаточно удалённые от зри теля, показаны в том же масштабе, что и расположенные на переднем плане. Таким образом расширение пространственного слоя не решает проблему глубины поля действия. Пространство миниатюры всё равно остаётся неглубоким.

Концентрация внимания художника на изображении отдельных объектов предметного мира тесно связана с субъективностью изображения пространства, о которой говорит Э. Панофски. В некоторых миниатюрах Ватиканского Вергилия эта субъективность приводит к тому, что определённые элементы композиций изображаются отдельно, в отрыве от единой пространственной логики. Ряд отечественных исследователей видят в подобных «искаженияХ» стремление изобразить предмет в наиболее выгодном ракурсе, таким образом, чтобы информация о нём была передана максимально полно ${ }^{23}$. Действительно, в композиции 17r расположенные на заднем плане море, граница береговой линии и остров переданы с более «высокой точки зрения, буквально сверху вниз. В то же время храм на острове изображён с фронтальной точки зрения, как и деревья, расположенные за ним на верхней границе плоскостного пятна острова. Подобное соединение плоскостного и трёхмерного изображения встречается неоднократно: можно вспомнить лист $6 r$, где внутри пространственного слоя неожиданно появляется разрушающее единство пространства изображение озера, из которого вытекает река: река «лежит» в плоскости поверхности в то время как озеро представлено не в ракурсе, а совершенно фронтально, как если бы мы смотрели на него сверху вниз. Также субъективность пространства проявляется в несоблюдении единства масштабности элементов композиции. В миниатюре 19r фигуры воинов несообразно велики 23 Флоренский П. Сочинения в четырёх томах. Т. З. Обратная перспектива. М.: Мысль, 2000. С. 46-98; Раушенбах 5.В. Пространственные построения в древнерусской жи-
вописи. М.: Наука, 1975; Успенский Б.А. Семиотика искус-

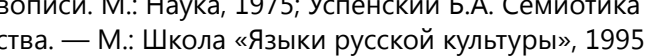

не только по сравнению со стенами города, но и с Троянским конём.

Таким образом, несмотря на то, что в позднеантичных пространственных миниатюрах была выработана определённая система построения пространства, эта система была достаточно гибкой и предполагала известную субъективность. Эта субъективность постепенно усиливается, начиная с середины $\mathrm{V}$ века ${ }^{24}$. С этого времени в книжной миниатюре происходит постепенный переход от отношения к образу как формируемой на плоскости иллюзии видимой реальности к образу как изобразительной единице, интегрирующей в себе целый комплекс знаний об объекте. Иными слоавтора, разнесенные во времени и пространстве. Соответственно, изображение нередко соединяе в себе различные точки зрения и разные ракур сы, что ведёт к его уплощению. Художественные средства, направленные на передачу объёма, такие как лепка формы светотенью, падающие тени соответствие поворота стоп плоскости поверх ности земли - все эти приёмы оказываются ненужными и постепенно уходят. Особое значение приобретает контур как объединяющее компози ционное начало, соединяющее различные ракурсы воедино. Образ как сумма знаний об объекте предполагает не только поиски наиболее выразительного ракурса, но и выражения лица, наиболее характерно отражающее представление нём как целостной личности, его внутреннем мире. Таким образом, принцип суммирования зрительных впечатлений в пространстве и времени по зволяет сообщить зрителю значительно больше информации об объекте, чем повторение на изобразительной плоскости единичного впечатлени от объекта в определённый момент времени. В известном смысле, можно говорить о том, что логи ка развития античного искусства не прерывается. Как и в античной иллюзионистической живописи в фокусе внимания находится объект изображения. Смещается акцент с субъективности единич ного взгляда на объект к большей объективности стремлению изобразить предмет так, как его знает художник, а не так, каким он видится.

Описанные изменения, происходившие, по всей видимости, постепенно, с разной скоростью в разных областях, можно проследить на примере ряд памятников переходного периода. Необходимо за-

24 Weitzmann K. Illustraitions in Roll and Codex. Princeton University Press, 1970. C. 56 метить, что, прежде всего, изменения коснулись характера изображения персонажей. Примером может послужить миниатюра со сценой Дидоны и Энея на пиру из Римского Вергилия 25, рукописи середины $\vee$ века, в которой впервые прослеживаются черты перехода к новой изобразительной системе. Стремясь передать расположение центральных персонажей миниатюры, художник объединяет несколько различных точек зрения: стол изображается с высокой точки зрения, как бы сверху вниз, а торсы персонажей, напротив, развёрнуты анфас и расположены вокруг стола. Лица главных действующих лиц для большей наглядности переданы анфас, их торсы увеличены относительно ног. Художник акцентирует внимание на главном: показывая вытянутую по направлению к столу руку левого персонажа, мастер изображает только кисть и предплечье, которые, по всей видимости, представлялись ему достаточными для передачи информации о действии героя. При этом плечо «опускается» художником как неинформативная деталь, которая могла бы помешать ритмическому единству и целостности изображения. Указанные искажения приводят к зрительному уплощению образов. Способствует этому впечатлению и характер изображения одежд персонажей, которые представляют собой локальные цветовые пятна, поверх которых накладывается линейный ритм складок.

Тем не менее, важно отметить, что описанные «искажения» в изображениях персонажей не разрушают основу системы пространственного слоя. Действие разворачивается на узкой горизонтальной площадке, ограниченной вертикальной плоскостью стены. Благодаря смещению композиционных элементов по вертикали формируется система планов: фигуры рабов расположены ближе, на переднем плане, далее - стол, а вдоль горизонтальной плоскости стены вытянулись фигуры возлежащих. Расположение фигур слуг, которые перекрывают горизонтальное ложе, свидетельствует о том, что они находятся ближе, и это, в свою очередь, зрительно выдвигает их на передний план. Таким образом, можно говорить о том, что в миниатюре Римского Вергилия сформирован пространственный слой. Однако стремление к суммированию нескольких точек зрительных впечатлений и общее уплощение образов приводит к тому, что ощущение пространственной динамики существенным образом ослабевает.

25 Biblioteca Apostolica Vaticana, Vat. lat. 3867.
Значимым изменением в организации пространства миниатюры становится соединение пространства, в котором развивается действие заднего плана. Так, в Евангелии Раббула ${ }^{26}$ (VI в.) на листе 14r, евангелисты, окружающие восседа ющего на троне Христа, изображены на зелёном поле, покрывающем своим ковром всё поле ми ниатюры. Художник не даёт никакого намёка на границу горизонтальной плоскости и фона. В то же время противопоставление горизонтальной поверхности земли, уходящей в глубину, и вер тикальной плоскости задника подразумевает ся, и это осуществляется некоторыми приёмами и деталями. Фигуры евангелистов анатомически пропорциональны, они освещены из одной точки (справа от каждой фигуры падает тень), стопы персонажей «стоят» на одной плоскости, то есть повернуты соответственно друг другу так, что зрительно угадывается плоскость, на которой расположены ноги. Кроме того, здесь также использован приём смещения по вертикали две фигуры, расположенные на листе ниже, вос принимаются ближе к зрителю, чем те, которые находятся выше. Таким образом, создаётся впечатление, что плоскость «сцены» как будто плавно перетекает в вертикаль фона

Напротив, в другой миниатюре Евангелия Раббула 1r, в сцене, посвящённой Пятидесятнице, ощущение пространственной динамики внутри изображения пропадает, хотя представленные персонажи расположен на таком же фоне в виде

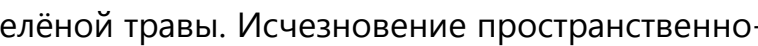
го слоя связано с соединением при построении пространства двух точек зрения. С одной стороны фигуры апостолов расположены по краю круглого поля, так что кажется, что сцена воспринимается с высокой точки зрения. С другой стороны, сами фигуры апостолов изображены строго фронтально. Таким образом, применение принципа сум мирования зрительных впечатлений приводит к тому, что фигуры персонажей кажутся как будто вырезанными и наклеенными на плоскость миниатюры. Соответствует этому впечатлению то, что апостолы, будучи изображёнными анатомически верно, совершенно лишены светотеневой градации и поэтому выглядят плоскими. Усиливают это эффект густые контурные линии, окружающие фигуры. Между персонажами присутствуют определённые пространственные отношения, однако они 
скорее угадываются, нежели изображаются. Расположенные ниже фигуры апостолов перекрывают другие, расположенные несколько выше, $и$ выступают на первый план миниатюры.

Таким образом, можно говорить, что в кодексах в позднеантичных миниатюрах, отделённых от текста рамой, происходит возвращение к $\mathrm{Cu}$ стеме пространственных планов. В известном смысле этот процесс можно рассматривать в контексте развития общей тенденции позднеантичного искусства, отмеченной Панофски: интереса к изображению объектов, порой в ущерб единству пространственной логики. Соответственно, эта тенденция в трактовке образов приводит к усилению субъективности в передаче пространства, а затем - к отказу от задачи создавать и иллюзию пространства. Для передачи пространственных отношений между образами достаточно обозначить эти отношения, указать на них, но не изображать. Для этого вполне достаточными оказываются художественные средства, которые использовались для обозначения пространственных отношений в иллюстрациях свитков, метод «наложения» образов друг на друга и метод «смещения по вертикали».

Приведём несколько примеров позднеантичных миниатюр с пространством, выстроенным планами. Это одна из небольших миниатюр, посвященных Страстям Христовым на листе 125 Евангелия святого Августина ${ }^{27}$ (VI в.). В одном из квадратных клейм верхнего ряда, посвящённом Тайной Вечери пространство организовано планами (рис 6). Христос и апостолы сидят за столом: фигуры персонажей изображены фронтально, стол представлен с высокой точки зрения. В то же время выстраивается система пространственных планов: стол закрывает от нас фигуры персонажей и как бы выходит вперед (рис. 7.). В свою очередь, апостолы изображены в два ряда, так что передний ряд закрывает от нас фигуры сидящих сзади и уводит их на задний, третий план.

27 Cambrdige, Corpus Christi College, Lib. MS. 286. Искусство, 1970.

mann K. Illustraitions in Roll and Codex. древнерусской живописи. - М.: Наука, 1975

Успенский Б.А. Семиотика искусства. - М.: Школа 7. Päсht О. Buchmalerei des Mittelalters: eine Einführung «Языки русской культуры», 1995

4. Флоренский П. Сочинения в четырёх томах. - Т. 3. Обратная перспектива. - М.: Мысль, 2000. С. 46-98.

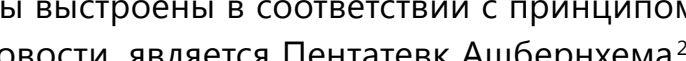
(VI - нач. VII в.). Так, в верхней части миниа-

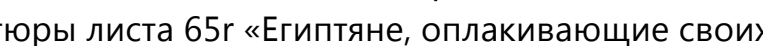
первенцев» изображённые достаточно условно персонажи, как будто парят на фоне постро-

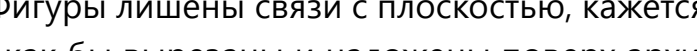
атюры. Таким образом, формируется два плана: на переднем разворачивается действие, а второй представляет собой развернутую архитектурную . Подобная система организации планового пространства будет чрезвычайно важна для среднеона будет востребована в иллюстрациях рукороманской эпохи, в которых плоскостны образы формируют сложную, многоступенчатую

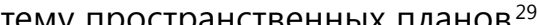

Таким образом, в позднеантичной книжной

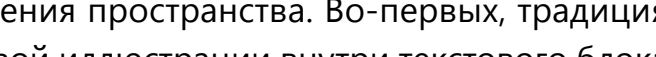

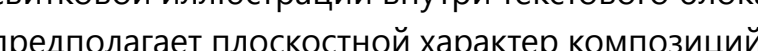
развивающихся по принципу фриза вдоль гори зонтальной линии. Во-вторых, появление рамки позволило создавать композиции, в которых сйствие развивается внутри пространственного слоя, ограниченного, с одной стороны, плоскостью листа, а с другой, - плоским задним плаобщего вектора развития искусства в V-VII вв. отделённые от

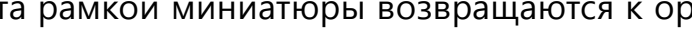
ции компози

Bibliothèque nationale de France, MS nouv. acq. lat. 2334. Pacht O. Buchmalerei des
Еуе одним примером памятника, чьи мини-

Irina V. Portnov

PhD, assistant Professor

Department of architecture of Engineering Academ

of Peoples ' friendship University of Russia

e-mail: irinaportnova@mail.ru

Moscow, Russia

ORCID ID: 0000-0002-9064-528

DOI: 10.36340/2071-6818-2021-17-4-49-61

\section{RUSSIAN ANIMAL ART OF THE XIX-XX CENTURIES IN THE VIEWS ON THE WORLD OF FLORA AND FAUNA}

Summary: The article dwells on views of artists-animalists of the XIX-XX centuries on the wildlife world. The worldview questions are considered as a factor of the value of the interconnection of human and wildlife world which is predetermined by the historical situation. The author underlines the indispensable role of the animal in the development of human civilization. So, this implies an ethical attitude towards nature as a unique value. It was ethical attitude towards nature as a unique value. It was anship, that became actual in the ora of global change

\section{Introduction}

In the 20th century, due to a heightened perception of the world of wildlife, reasoning on the subject of relationship of human and animals became especially actual, what, in its turn, has led people to the pursuit of a deeper analysis of the heritage of animal artists. It's worth to pay attention to articles of V. A. Tikhanova [Tikhanova, 1990: 238], which are written in style of artistic and critical essays. Their importance is in the problems that are considered in them, which are closely tied up with the moral and ethical evaluation flowing out of the main meaning of painter-animalist's works. The author notes that among a variety of expressive means and techniques, which painters of the 20th century turn to, there is a conception of the wildlife protection that is correlated with tasks of the animalistic art at the modern step. The painter-animalist, V. Vatagin, was arguing on the same topic on the pages of his memoir «Memories. Animalist's notes» [Vatagin 1980: 213], the base of which consists of materials of the previous edition, «The image of animal» [Vatagin, 1957: 170]. The work of Vatagin and a book of I. S. Efimov published in 1977, «About art and artists» [Efimov,1977: 323], include artistic and theo- and the crisis of the ecological situation, was contributing to the formation of ecological way of thinking as the reality of the New time. According to the artist-animalist's worldview, an animal looks beautiful, its behavior is expedient, that has a beneficial impact on human. The interconnection of artists' points of view and the way how they see the animalistic image from the position of humans of the New time are also considered in this article.

Keywords: domestic animals, ideology, nature, ecology

retical views of masters on the world of wildlife and the art of animalism, methods of work in sculpture and graphics. So, a clear statement of artists' views on the animal world and the art of its image (especially consecutive Vatagin's ones), allows us to reveal their system of values and ideals, which turned out to be very relevant in the era of setting global environmental problems.

Nowaday's researchers talks about new mora standards regarding wildlife. In the ancient cultures animal was always included into the field of the myth, folklore, human's thoughts and dreams, was a kind of symbol, what was reflected at the level of the collective and individual mind [Caspari Elizabeth 2003: 350], but in the era of technological revolutions there was a kind of tension between people and animals, which sometimes manifested in a mis understanding of the very essence of nature $[\mathrm{Pe}$ terson Anna 2013: 236]. Samantha Hurn [Samantha Hurn 2012: 266] talks about the need of development of the eco tourism nowadays.

In the aspect of reasoning, the relevance of the article is determined by the need to study the ideological principles of the work of animal artists, firs of all, being the base of the creative intention of the 


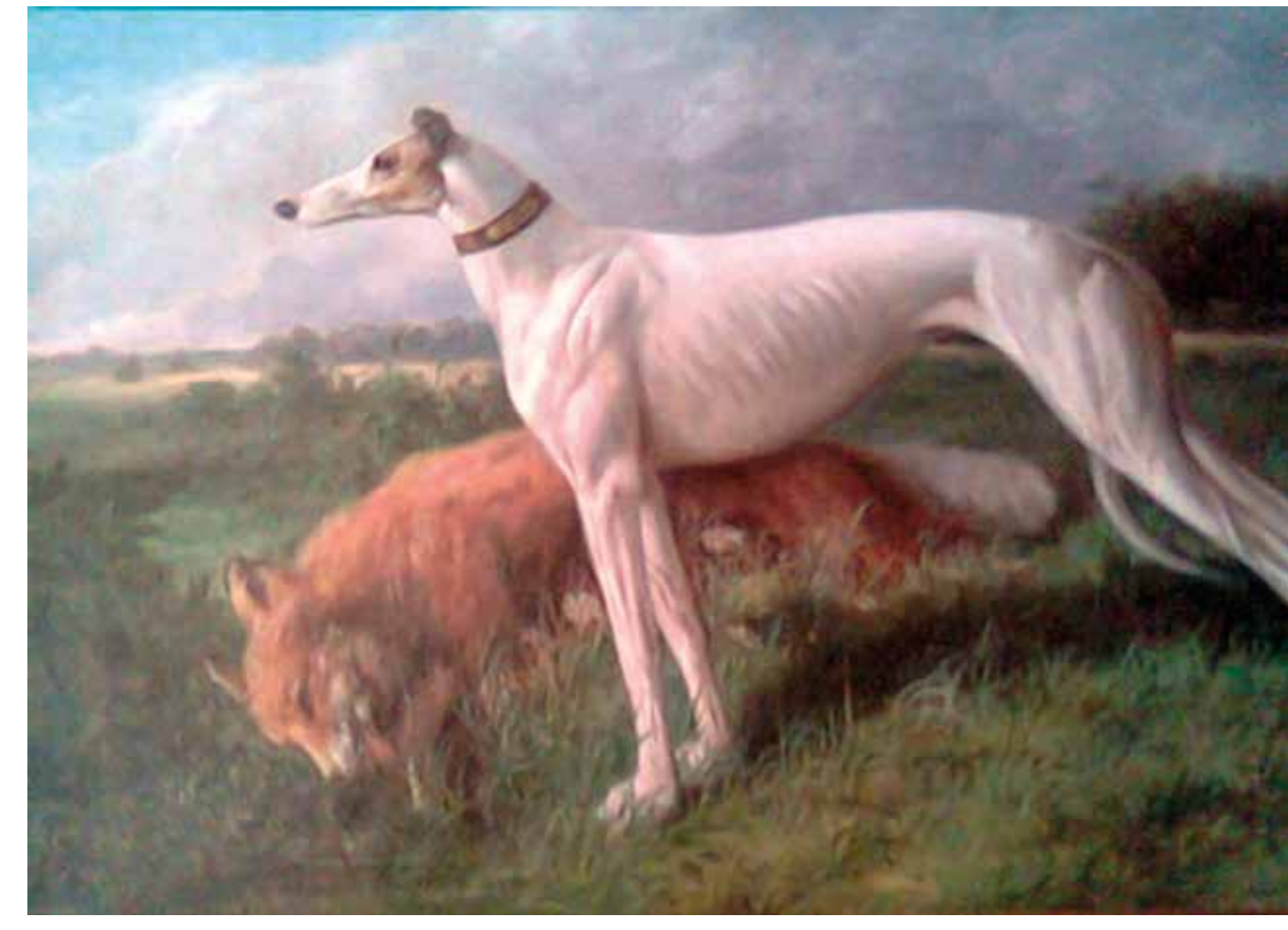

III. 1. N. E. Sverchko. A greyhound dog with a fox. X, M, 1890. GRM

master, secondly, significant in the universal sense, as problems of the safety of all life on earth, which led to the formulation of the problem of the relationship "nature-man". These two interrelated as pects, that were predetermined by the epoch, are significant in the sense of comprehending the specifics of the animal painting genre, which left high artistic standards in the heritage.

The methodology of the research is the theoretical analysis of the problem in the historical context of two eras. Letters, memories of the artists served as the basis for consistent consideration of this issue.

The basic worldview and artistic principles

Let's consider the points of view of artists-animalists on the wildlife world of the 19th and 20th century, of the man's perception of nature was changed cardinally, its role and meaning in the humans society, values of the alive creature.

Let's pay attention to the fact that the hunting theme takes a big spot in the Russian genre painting of the 19th century. It became widespread in the XVIII century, then the paintings of the relevant subjects in the XIX century acquired a new artistic expression. The interest in this topic is explained by its popularity in Russian society since tsarist times. In the second half - the end of the 19th century in the era of Alexander II and then Pavel I, along with the imperial hunt, there were provincial ones, farms, using commercial animals, were developing fast. At the same time, besides the type of trade which ensures the vital activity of man and asserts his superiority over nature, the hunt continued to be the same attribute of life as secular balls and military parades. A large edition of N. I. Kutepov: "The Grand Ducal Tsar Hunt in Russia from the 10th to the 16th Century" [Kutepov 1896:211], "The Tsar Hunt in Russia of the Tsars Mikhail Fedorovich and Alexei Mikhailovich of the 17th Century" [Kutepov 1898: 315] "The Imperial Hunt in Russia the end of the 18th and the 19th century" [Kutepov, 1911: 328] was considered as a bright fact

The hunting as a hobby had let to a wide variety of works in which the "hunting" animals wer taking a central place, they were seen by artists in the realization of their hunting characteristics and in the indispensable natural environment. It is worth to remember the paintings by N. E. Sverchkov, P. P. Sokolov, R. F. Frents, A. D. Kivshenko, sculptures by A. L. Ober, E. A. Lanceray (Fig. 1,2,3)
Images of national scenes - Russian provincia hunts determined the thematic range of their works, within which ones the masters found a variety of plot options. A large place was taken by the image of hunting dogs - Russian borzoi. Their popularity was caused by the fact that in the 19th century people looked at this as an advantage if they took dogs to the hunt too, which ones consisted mainly of greyhounds and hounds. N. Kutepov in his historical essay describing the imperial hunt in Russia of the end of the 18th-19th centuries, noted that as dogs for hunting, which replaced the tsar's hunting birds (falcons, golden eagles, hawks, peregrine falcons, saker falcons), along with hounds and greyhounds were used dogs of other breeds: "Medellan, Moscow water dog and English setters, but in a small number (...). The "cop dogs" that were kept by chasseurs and poultry houses were also belonged to that list.(...) Dogs, that were the property of the emperor, empress, heir-tsarevich and some of the grand dukes, were kept on special grounds. (...) Good dogs were bought at landowners, among which ones there were a lot of passionate hunters》 [Kutepov, 1911: 328].

In the "hunts" of painters there are a lot of "royal", grandeur and pomp, greyhounds with their beautifu outlines backed up with their expressive aristocratic appearance. Their movements are graceful, bodies are rhythmic. Here, certainly, the poetic interpretation of the animal can be read. However, there was barely someone who thought about a moral side of it. The «hunt» wasn't considered from the moral side at those times. People weren't used to talk about the damage they brought to the wildlife and the feelings experienced by animals in stressful situations. A. L. Ober, sculptor-animalist, wrote about it in his works. For example: «In France, if there is law, then a positive one, the hunt is strictly organized, the foresters serve the fields and forests. A a certain time only the right to hunt is given only for a well-known fowl and strictly defined but the right for a hunt for a deer was very expensive, and the hunter is allowed to kill only a certain number of deers. It's a well-known fact that it's a very cruel kind of pleasure. On the eve of the planned hun people choose a potential victim and, in the morning, when the red-fesco hunters gathered on horseback, the deer gets frightened from the spot and a desperate chase begins, followed by a dozen of toothed dogs, a true pursuit for the innocent animal for life and death, but the animal, exhausted suffering from ever-increasing fear and exhaustion is finally caught and not just by one, but dozens of dogs as a triumph over a defenseless animal! The nimal is slaughtered $n$ and one of the most beautiful ladies will probably receive deer's legs and the whole a triumphing crowd, full of emotions, with a cheerful and full of happiness laugh. is filling the stomaches up with such a nice dinner. There is no end for stories about adventures, but is there at least a drop of the pity for defenseless creature? Do they even understand?». The sculptor continues the thought: «Nature could exist forever in its wildness, in its poetic setting. I like the hunters' innocent glances - "looks like there is no more fowl and fish but recently there was way more". And they don't want to recognize, that just like their predecessors, they are ready to exterminate everything like predators just with the intention of their wishes satisfac tion. Evil rock is coming to replace the Divine wild harmony of nature. in all its inexhaustible origina beauty, and bringing destruction of all alive creatures. But does the people get any better? Everyone knows by the history of humanity how much blood is spilled» [Ober, 1917].

The epoch of the 20th century, indicated by the exacerbation of global problem, has brought the new vision of the world, of flora and fauna. In the dialog of human and nature artist-animalist stands on the side of nature. This conclusion is explained not only by the field what masters work in but also by their deep conviction, that more and more finds a feedback in the scientific community, - about the need in the dialogue of human and wildlife at the new level. In the first half of the 20th century, the human interest in research led to the fact that the boundaries of interaction between man and nature are becoming ever closer, and understanding of an animal is becoming more personal and specific, nature appears permeated with thought and experience. In the 20th century "The theory of" related attention " by M. Prishvin becomes popular not accidentally. It implies a depth of penetration into the lives of animals, birds and plants, which have their own unique "fate", their place in the universe. An imals, just like people, are endowed with personality traits. The admiration for the beauty of the anima world and its understanding brings us to a high moral sense»

In a process of affirmation of the significance of animalistic art, the world of wildlife, wild animals, organizing their lives independently of man, an im- 
portant role for masters and researchers belonged to science, which in the first half of the 20th century was directed on the active exploration of them. It's important to note that animalists V. Vatagin, V. Smirin, N. Kondakov had professional knowledge in the field of biology, were collaborating with the Darwinian Museum in Moscow for many years, performing an extensive series of illustrations on the themes of zoology, zoopsychology. Other artists, not having a biological education, comprehended the lives of animals and birds by intuitive means and artistic instinct, everywhere observed and studied nature.

The problem was that the animal appeared in front of scientists and artists eyes as a multifaceted creature. Researchers and artists found value in the interpretation of various manifestations of the life of animals, primarily wild: free, strong, independent. Their views on the value of nature and animals in it played a certain role. Among all of the classes, types of the animal kingdom, sculptors often gave their priority to the image of a mammal with bright natural plastic properties. For the first time, a biologist and an artist in one person concentrated their efforts on the solution of a complex task is the interpretation of the mental characteristics of wild animals and birds by means of art. The interest was cause by the mood of society and changes that were happening in people's minds looking at nature and animals not from a consumer point of view (as a source of satisfaction of their needs), but from the standpoint of knowledge and understanding of this world. In this connection, the view of the 20th century animalists on the world of nature, which are based on ethical and aesthetic ideas, has its own characteristic. In the relationship of human and nature, animal painters mark a dramatic moment. They see nature suffering, as the universal "drama of the organic macrocosm." In letters, on the pages of magazines, they talk about the destiny of wildlife and animals. Let's consider the statements that eloquently characterize the way of thinking of the artist-animalist of the 20th century. The heartfelt, sympathetic attitude to the world of nature is expressed in the words of B. Vorobiev. Talking about nature reserves as a certain preserved piece of the original world, he comes to disappointing conclusions: «The fate of all reserves looks pathetic (...) I'm afraid that even in this century many species of creatures will be eliminated. We leave a very poor inheritance for our following generations. There will be less and less people who are close to nature looking a true inspiration and consolation in it but, after all, many material "benefits", that are acquired by humanity, are not able to compensate the losses inflicted on the world by these acquisitions, because stomachs acquire more than souls.» [Vorobiev, 1959-60]. In the letter to V. Vatagin, D. Gorlov frankly admits: «It is necessary to communicate with animals and birds, dear to my heart, in order to reach a human condition.(...) Animal is way nobler, more sincere and less cunning than human [Gorlov, 1960-68].

Underlining the great significance role, which an mals have played in the development of civilization V. Vatagin sees the animal world under the sign of ry-historical tragedy and drama of the organic macrocosm: «No animal will torture or kill its victim in vain. What a destructive role, howeve human plays sometimes regarding animals! What a huge bloody bill nature could ask human to pay off for a numerous many predatory exterminated beautiful species of animals created by it!» [Vatagin, 1957:170]. «And when they kill for fun, I always worry as if it's the loss of something very close, dear to me...» - the artist shares.

The meaning of the statements is to justify the historical role of animals in the development of civilization. Masters invariably affirm the idea that nature-animal-human is a complex, fluid, historically developing structure, where everything is tied up with each other like in the thinnest nervous organization. There can't be an impassable abyss between them as in anatomy, physiology, as in the processes happening in them. With the whole course of thei thoughts, they emphasize that without this world, the existence of human is probably impossible.

Vatagin, Gorlov, Efimov, Sparrow lived at that time, when the situation, bringing up the issues of the wildlife protection, caring attitude of human to it, took place in the society. That's why animalist reasonings on this topic are quite natural. As we've mentioned A. Ober was concerned about these questions, who also was talking about the value of nature, about the perfection of animals, their different personalities and spoke very negatively about the hunt. The sculptor condemned all sorts of hunting fun, he couldn't understand hunters who killed such a huge number of animals, who could see only combination of bones and body weight in an animal without any «spiritual manifestation» and only «alive objects for a hunting pleasure». Nevertheless, his reasoning about hunting had a private charac-

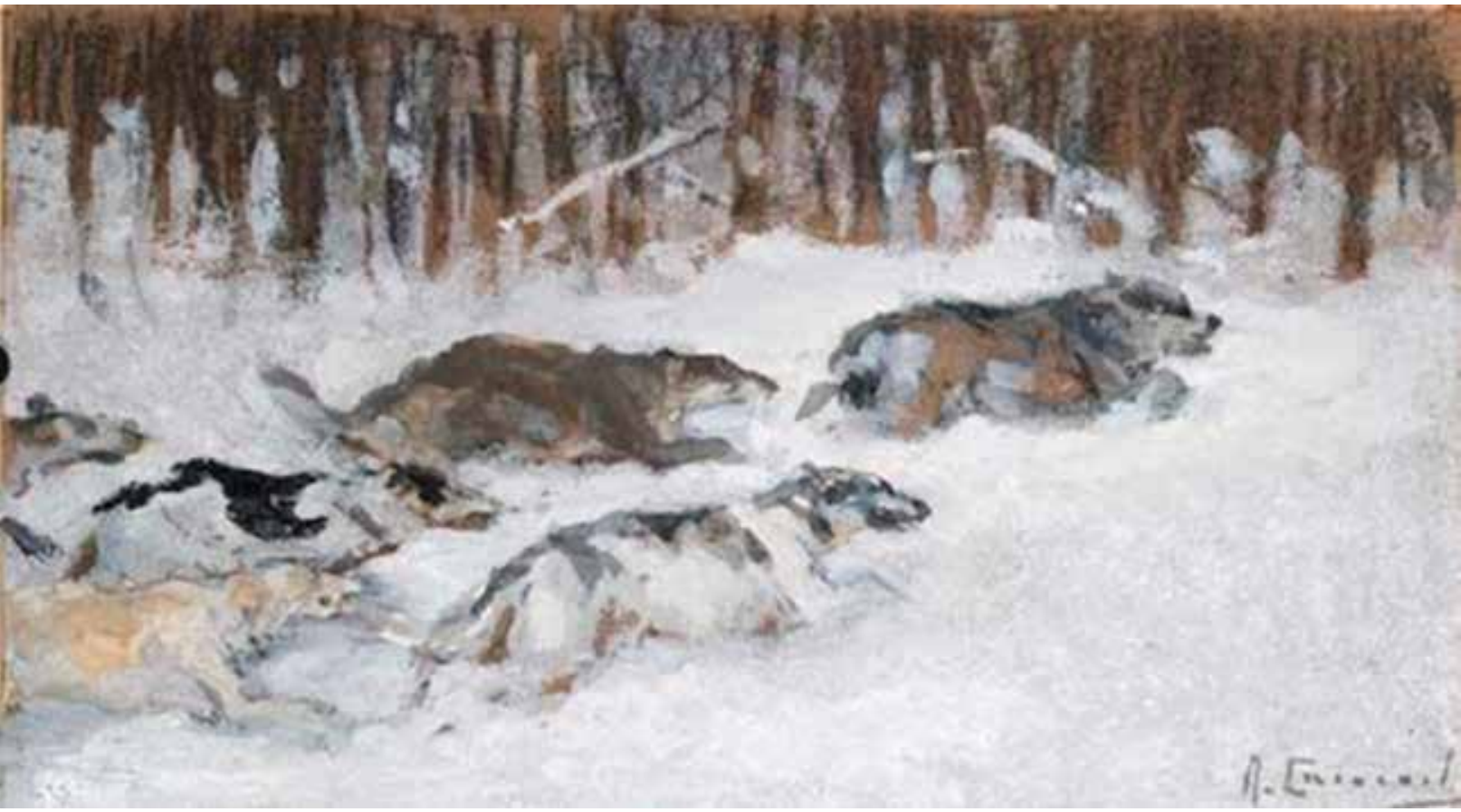

III. 2. A. S. Stepanov. Hounds of the 1910 s cardboard, tempera, timing

ter and wasn't a tendency exciting society, which, in general, did not prevent the sculptor from creating works depicting hunting and fighting animals, filled with strong tension and expression.

The works of animalists of the 20th century were different. Let's explain their interest in ancient cultures. Masters highlight the Ancient East. In their opinion, there animal was in high esteem. V. A. Vatagin was impressed by the art of ancient Egypt D. V. Gorlov, I. S. Efimov - by folk art, which determined their creative pursuit a lot $V$ Vatagin points at the significant place that animals had been taking in the ancient art. The art of Assyria, China, Egyp was consonant with the ideals of the artist. On the example of many works and masterpieces, he saw a picture of the human-animal relationship, which impressed him. The animal as a "divine creature "[Ryabinin, 1972:372], was a vivid expression in ancient Egyptian and Assyrian animalistic. An animal-hero in the images of the mighty bull, the lion is enclosed in the widely generalized, expressive forms of monumental-decorative art. The master was impressed by the ornamental art of the Scythians, where the animal in the weaves of a decorative composition is turned almost into a heraldic sign and with its conventional and at the same time really recognizable forms exudes a certain magical power. Artists also observed great interest in animals in the folk art. Animals and birds were an integral part of human life. Animalistic images, which are inherently con- ditional and very primitive, contain valuable qualty - spirituality. Animals were filled up with the thoughts, feelings, mood of humans, they were the organic whole with them.

In his memoirs I. Efimov draws attention to the works of art of the peoples of the East, as well as to the monuments of Russian folk art, which, in his opinion, «are examples of the truly high, forever inspiring art» [Efimov, 1977:423]. It is exactly where the sculptor feels the natural foundations of the animalistic image. D. Gorlov is also tend to rely on folk art. In the letter to E. N. Vataginoy He clearly defines his direction: «My foundation was the nature and folk art.» [Gorlov 1960-e].

About these cultures and the role of animals in them narrated by many authors. Bria Sex [Boria Sax 2001:298], Simon Lewis, Lloyd Llewellyn-Jones [Boria Sax, 2001:298], talk about the importance of understanding animals for modern man. They cover a wide range of time, focusing on the ancient culcance of the sacred animals of dynastic Egypt, as Vatagin wrote. Paul Waldau, Kimberley Christine Patton Waldau Paul, Kimberley Patton, 2009:686] noted that animals were present in all the religions of the world and reflects religious rituals, presenting a whole system of beliefs, myths. Their study contributes to a deeper understanding of human society as a whole. 


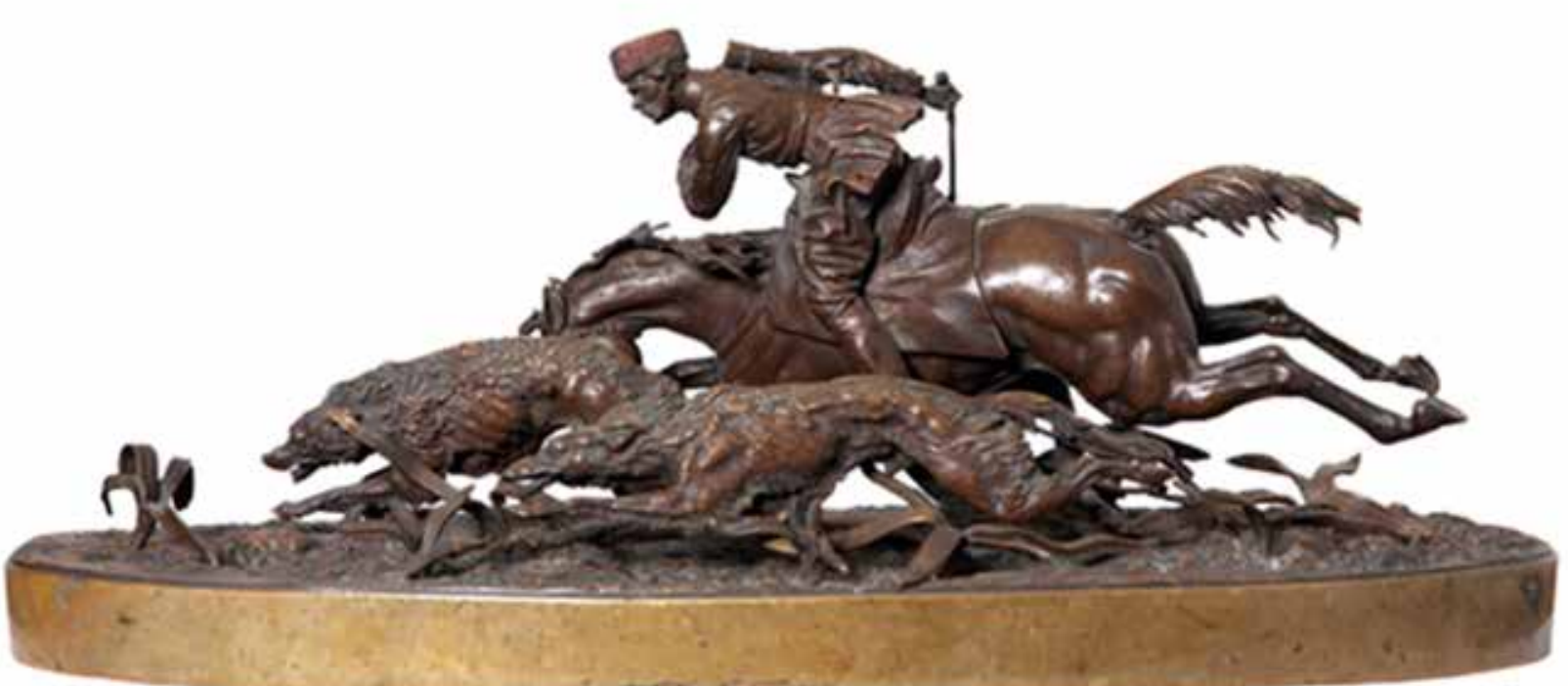

III. 3. N. I. Liberikh Hunting with greyhounds, bronze

The selection of precisely these periods in the development of animal painting is caused by the views of artists on the animal world and the painting skills. The symbolic perception of the image, a certain conventionality of the pictorial language these qualities impose the attitude of the artists. In sense of worldview in terms of modernity, the animalistic image of the past is highly relevant. The meaning of the animalistic art of the 20th century lies in the fact that it could most fully recreate the panorama of the natural world, associated in a broad sense with «the picture of the world». In the 20th century, a look at the world of nature and art, easel graphics, sculpture and painting, monumental-decrative works, plastic of small forms are the essence of one artistic concept of masters. It's a conception of a philosophical attitude. Art works acquire a multifaceted character. We can trace in them a variety of different shades of one theme, unexpected creative solutions, including traditions and styles of past eras. We don't even have to talk about genre boundaries. The modern animalistic art, brightly demonstrating a variety of pictorial plastic options, keeps on reflecting environmental theme, which in the modern world is becoming even more relevant In modern animalistic art, that branch of is important, which studies the general laws of interaction between animate and inanimate nature, in particuar, the problems of the influence of modern civilization on the world in general. loving and worshiping the world of living nature, their adherence to the traditions of ancient art, in which the animal was often depicted, as well as professional knowledge, all together defined the creative face of the painter-animalist of the 20th century, who is oriented on the demand of time In their statements, the animal painters revealed a holistic picture of the relationship between nature and man, the place of man in this world. Their opinions, judgments, teachings are interesting and useful for both as specialists, as a wide audience. On this path, speaking in its own independent genre quality, as a modality of a new thematic reality, the genre beginning of which found an expression in various types of fine art, it played an undoubted role in the broad world outlook as a value factor in the interaction of nature man and narrower as the visual theme of time.

The theme of nature and animals keeps on bring relevant in our time, besides, the educational aspect all for children and young people.

Acknowledgments. This paper has been sup ported by The RUDN University Strategic Academic Leadership Program on Soviet animal sculptors, Moscow, p. 238

Vatagin, V. A. 1980. Memils, Notes of an animalist. A-

4. Efimov, I. S. 1977. About art and artists. Moscow p. 423

9. Kutepov, N. 1898. Imperial hunting in Russia of tsars

In conclusion, we note that the ideological principles of artists-animalists, based on understanding
1. Tikhanova, V. A. 1990. The face of living nature.Essays ticles. Moscow, p. 213

3. Vatagin, V. 1957. A. The image of an animal: notes of an animalist. Moscow. p. 170 5. Caspari Elizabeth. 2003. Animal Life In Nature, Myth and Dreams. Chiron Publications, p. 350

6. Peterson Anna. 2013. Being Animal: Beasts and Boundaries in Nature Ethics, Columbia University Press, p. 236

7. Hurn, Samantha. 2012. Humans and Other Animals: Cross-Cultural Perspectives on Human-Animal, Pluto Press, p. 266

8. Kutepov, N. 1896. Grand Duke Royal hunting in Russia from X to XVI century. Historical essay. SPb.: The expedition of storing state papers. Edition. 2. vol. 1-3, p. 211 Mikhail Fedorovich and Alexey Mikhaylovich of XVII century. Historical sketch: Saint-Petersburg. Edition 2, vol. 2, p. 315

St. Petersburg: Expedition of preparation of state papers, p.328 RGALI. F. 1956. Op. 2. Ed. HR. 13

12. Letter Vorob'eva, V. A. Vataginu V. 1959-60s., RGALI. 3022. Op.1. Ed. HR. One hundred three,

3. Letters Gorlov D.V. Vatagin VA 1960-68., RGALI. F. 3022 Op.1. Ed. HR.One hundred seven.

14. Letter Gorlova DAY.Vatagina (with mention of Vatagina). 1960's, RGALI. F. 3022. Op. 1. Ed. HR. 191

15. Sax, Boria. 2001. The Mythical Zoo: An Encyclopedia of Animals in World Myth, Legend, and Literature. ABC CLIO, p. 298

16. Lewis, Sian, Lloyd, Llewellyn-Jones. 2018. The Culture of Animals in Antiquity: A Sourcebook with Commen taries. Routledge, London, p. 778

17. Waldau, Paul, Kimberley Patton. 2009. A Communion of Subjects: Animals in Religion, Science, and Ethics, $\mathrm{Co}$ lumbia University Press, p. 686

10. Kutepov, N. 1911. Imperial hunting in Russia of the end of XVIII and XIX centuries. Historical essay, vol. 4.
B. S. 1972. Zeropanic Vatagin. Looking at life. Sverdlovsk, Sredne-Uralsky Book Publishing House, p. 372. 
Ирина Васильевна Портнова

Доцент департамента архитектуры

инженерной академии

Российского университета дружбы народов

e-mail: irinaportnova@mail.ru

Москва, Россия

ORCID ID: 0000-0002-9064-5288

DOI: 10.36340/2071-6818-2021-17-4-49-61

\section{РУССКОЕ АНИМАЛИСТИЧЕСКОЕ ИСКУССТВО XIX-XX BEKOB ВО ВЗГЛЯДАХ НА МИР ФЛОРЫ И ФАУНЫ}

Аннотация: Статья освещает взгляды художников-аималистов XIX-ХХ веков на мир живой природы. Мирогоззренческие вопросы во многом предопределёноисторической ситуацией, рассматриваются как ценностнй фактор взаимосвязи человека и мира живой прирой фактор взаимасвяи чолеркваеся незаменимая роль животного разиитии человеческой цивилизации. Отсюда следуе этическое отношение к природе как уникальной ценности. Отмечается, что нравственно-этическая основа этих

взаимоотношений, ставшая актуальной в эпоху глобаль-

\section{Введение}

В XX веке в связи с обострённым восприятием мира живой природы весьма актуальными становятся рассуждения на тему взаимоотношений человека и животных, что привело к стремлению более глубоко проанализировать наследие художников-анималистов. В этом отношении можно отметить статьи В. А. Тихановой [Тиханова, 1990: 238], которые носят характер художественно-критических очерков. Они важны постановкой проблемы, тесно связанной с нравственно-этической оценкой, вытекающей из самой сути творчества художника-анималиста. Автор отмечает, что в многообразии выразительных средств и приёмов, к которым обращаются художники XX века, ясно звучит концепция сохранности живой природы, соотносимая с задачами анималистического искусства на современном этапе. На эту же тему рассуждал художник-анималист В. Ватагин на страницах своего мемуарного труда «Воспоминания. Записки анималиста» [Ватагин, 1980: 213], в ос нову которого были положены материалы бо лее раннего издания «Изображение животного ных перемен и кризиса экологической ситуации, способствовала формированию экологического мишления как реальности Нового времени В мировоззрении художника-анималиста животное выгларит красивии хего поведение целесообразным, оказывающим благотворное влияние на человека. Рассматривается взаимосворвзгядов художника и видение им анималистического

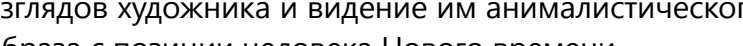

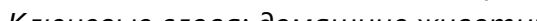

нные, идеология природа, экология.

[Ватагин, 1957: 170]. Труд Ватагина и вышедшая в 1977 году книга И. С. Ефимова «Об искусстве и художниках» [Ефимов, 1977: 323] содержат художественно-теоретические взгляды мастеров на мир живой природы и искусство анималистики методы работы в скульптуре и графике. Так, яс ное изложение точек зрения художников на мир животных и искусство их изображения (особенно последовательное у Ватагина), позволяет выявить их систему ценностей и идеалов, которые оказываются весьма актуальными в эпоху постановки глобальных экологических проблем.

Исследователи нашего времени говорят о новых моральных стандартах в отношении живой природы. Если в старых культурах животное всегда включалось в область мифа, фольклора, челове ческих мыслей и мечтаний, было символичным что отражалось на уровне коллективного и инди видуального разума [Caspari Elizabeth, 2003: 350] то в эпоху технологических революций наблюдалась определённая напряжённость между людьми и животными, непонимание самой сущности живой природы [Peterson Anna, 2013: 236]. Саман- та Хурн [Samantha Hurn, 2012: 266] говорит о необходимости развития в наши дни экотуризма.

Актуальность статьи определяется необходимостью изучения мировоззренческих принципов творчества художников-анималистов, во-первых выступающих основой творческого замысла мастера, во-вторых, значимых в общечеловеческом смысле, как задачи сохранности всего живого на земле, обусловившей постановку проблемы взаимосвязи «природа - человек». Эти два взаимосвязанных аспекта, предопределённые эпохой, являются значимыми и в смысле постижения специфики жанра анималистики, который оставил в наследие высокие в художественном отношении образцы.

Методологией исследования выступает теоретический анализ рассматриваемой проблемы в историческом контексте двух эпох.

Основные мировоззренческие и художественные принципы

взгляды художников-анима стов на мир живой природы XIX и XX столетий, тех исторических периодов, когда кардинальным образом поменялось восприятие человеком при роды, её роли и значения в человеческом обществе, ценности самого живого существа.

Отметим, что в русской жанровой живопиcи XIX века большое место занимает тема охоты. Широкое распространение она получила в XVIII веке, затем картины соответствующей тематики в XIX столетии приобрели новое художественное воплощение. Интерес к данной теме объясняется её популярностью в русском обществе ещё с царских времен. Во второй полови не - конце XIX века в эпоху Александра II, а затем Павла I наряду с императорскими охотами имели место провинциальные, широким ходом шло развитие хозяйств, использующих промысловых животных. Одновременно из промысла, обеспечи вающего жизнедеятельность человека и утверждающего его превосходство над природой, охота продолжала быть таким же атрибутом жизни, как светские балы и военные парады. Как яркий факт увлечения охотным занятием ещё с царских вре мён выступило большое издание Н. И. Кутепова: «Великокняжеская царская охота на Руси с X по XVI век» [Кутепов, 1896: 211], «Царская охота на Руси царей Михаила Фёдоровича и Алексея Михайловича. XVII век» [Кутепов, 1898: 315], «Импе раторская охота на Руси. Конец XVIII и XIX век» [Кутепов, 1911: 328].
Увлечение охотой породило большое разнообразие произведений, в которых «охотничьи животные занимали центральное место, виделись художниками в реализации их охотничьих признаков и в непременном природном окружении. Стоит вспомнить картины Н. Е. Сверчкова, П. П. Соколова, Р. Ф. Френца, А. Д. Кившенко, скульптуры А. Л. Обера, Е. А. Лансере (рис. 1, 2, 3).

Изображения национальных сцен - русских провинциальных охот определяли тематический круг их произведений, в границах которых мастера находили разнообразные сюжетные вари анты. Большое место отводилось изображению охотничьих собак - русских псовых борзых. Их популярность объяснялась тем, что в XIX веке преимуществом пользовались псовые охоты, которые состояли главным образом из борзых и гончих собак. Н. Кутепов в историческом очерке, опи сывающем императорскую охоту в России конца XVIII-XIX веков, отмечал, что в псовой охоте пришедшей на смену царской с ловчими птицами (соколами, беркутами, ястребами, сапсанами, балобанами), наряду с гончими и борзыми использовались собаки и других пород: «меделянские водолазы, духовые и сеттера, но в незначительном числе (..). Принадлежали еще легавые собаки, которые содержались егерями, егерскими учени ками и птичниками. (...) При особых основаниях содержались собаки, составляющие собствен ность Императора. Императрицы, Наследника Цесаревича и некоторых Великих Князей. (...) Хорошие собаки покупались у помещиков, среди которых было немало страстных охотников» [Кутепов, 1911: 328]

В «охотах» живописцев много «царского», величия и пышности, борзые красивого очертания запечатлены в своём выразительном аристократическом облике. Их движения изящнь тела ритмичны. Здесь, безусловно, прочитыва ется поэтическая трактовка животного. Однако мало кому в голову приходила мысль о моральной стороне дела. С нравственных позиций в то время «охоты» не рассматривались. Не принято было говорить об ущербе, которые они наносили дикой природе, и о тех чувствованиях, которые испытывали животные, оказавшиеся в стрессовых ситуациях. В своих воспоминаниях об этом красноречиво писал скульптор-анималист А. Л. Обер. Приведём его показательные рассуждения: «Во Франции если есть закон, то положительный, охота строго организована, обслуживают поля и леса 
лесничие. В известное время только на известную дичь даётся право на охоту строго опреде лённое, но на охоту оленя продаётся любителю очень дорого, да и владетелю позволяется уби вать только известное количество оленей. Всем известно это донельзя безжалостное удовольствие. Праздным радостным кавалерам и нежным дамам, упражняющимся в этой спортивной охоте. Накануне намечается логовище намеченного зверя, а на утро при собравшихся верхами красно-фрачных охотников олень спугивается с места и начинается отчаянная гоньба, за ним с помощью десятка зубастых собак, гоньба по истине только для невинного зверя не на жизнь, а на смерть, но вот зверь, измученный, настрадавшийся от все усиливающегося страха и утомления, наконец схвачен и не одним, а десятками псов как торжество над беззащитным зверем Зверь зарезан и какой-то из прелестнейших дам преподносятся оленьи ноги и вся торжествующая толпа, раскрасневшаяся, разгоревшаяся с полным смехом и радости торжества наполняют свои истощенные желудки наисытнейшим и весёлым обедом. Рассказам о приключениях нет конца всё до крайних мелочей вспоминается, но в сердцах христианнейших победителей есть ли места хоть проблеску жалости к беззащитному существу, да и поймут ли они?» Скульптор продолжае мысль: «Природа в своей дикой бытности могла бы существовать бесконечно в своей поэтической обстановке. Мне нравятся наивные взгляды охотников, что «что-то нет больше дичи и рыбы, а сперва столько её водилось. И не хотят сознаться, что как и их предшественники, так и они готовы всё хищнически истребить, лишь бы только им теперь поохотиться или поживиться во всю сласть. Злой рок ведёт на замену Божественной дикой гармонии природы во всей её неисчерпаемой оригинальной красоте и несёт истребление всего живого. Но сытнее ли становится от этого народ, каждый знает по истории людей, сколько крови пролито» [Обер, 1917].

Эпоха XX века, обозначенная обострением глобальных проблем, привнесла новое видение мира флоры и фауны. В диалоге человека с природой художник-анималист стоит на стороне природы. Данное умозаключение объясняется не только родом занятий мастеров, но и их глубинным убеждением, всё больше и больше находящим отклик в научной среде,- о необходимости диалога человека с живой природой на новом уровне.
Исследовательский интерес человека в первой половине XX века привёл к тому, что границы взаимодействия между человеком и природой становятся всё более тесными, а пониман вотного всё более личностным и конкретным, природа предстаёт пронизанной мыслью и переживаниями. Не случайно в XX веке «получае распространение теория «родственного внимания» М. Пришвина которая подразумевает глубину проникновения в жизнь зверей, птиц и растений, у которых своя неповторимая «судьба», своё место во Вселенной. Животные, как и люди, наде ляются чертами индивидуальности. Восхищение красотой животного мира и понимание её рождает высокое нравственное чувство».

В процессе утверждения значимости анималистического искусства, самого мира живой природы, диких зверей, организующих свою жизнь независимо от человека, немаловажная роль для мастеров и исследователей принадлежала науке, которая в первой половине XX века была направлена на их активное изучение. Важно отметить, что анималисты В. Ватагин, В. Смирин, Н. Кондаков обладали профессиональными знаниями в области биологии, много лет сотрудничали с Дарви новским музеем в Москве, выполняя обширный цикл иллюстраций на темы зоологии, зоопсихологии. Другие художники, не имея биологическо го образования, постигали жизнь зверей и птиц интуитивным путём и художественным чутьём повсеместно наблюдали и изучали природу.

Проблема состояла в том, что животное предстало перед взором учёного, художника существом многогранным. Исследователи и художники находили ценность в интерпретации разных проявлений жизни зверей, прежде всего, диких свободных, сильных, независимых. Здесь сказались их взгляды на ценность природы и живот ных в ней. Среди всех классов, видов звериного царства скульпторы часто отдавали приорите образу млекопитающего, обладающего яркими природно-пластическими свойствами. Впервые биолог и художник в одном лице сконцентрировали свои усилия над решением сложной задачи - интерпретации психических особенностей диких зверей и птиц средствами искусства. Интерес был обусловлен настроениями в обществе теми изменениями, которые происходили в сознании человека, смотрящего на природу и жи вотных не с потребительской точки зрения (как источник удовлетворения своих нужд), а с по- зиций познания и понимания этого мира. В этой Связи характерен взгляд художников-анималистов XX века на мир живой природы, которые базируются на этических эстетических представлениях Во взаимоотношениях человека с природой анималисты отмечают драматический момент. Они видят природу страдающей, как всеобщую «драму органического макрокосмоса». В письмах, на страницах журналов они рассуждают о судьбе живой природы, животных. Приведём эти высказывания, которые красноречиво характеризуют мышление художника-анималиста XX столетия. Проникновенное, участливое отношение к миру природы выражено в словах Б. Воробьёва. Ведя разговор о заповедниках, как некой сохрани шейся частице первозданного мира, он приходит к неутешительным выводам: «Жалкой представ ляется судьба всех заповедников (...) боюсь, что ещё в этом столетии будут уничтожены многие виды существ. Неважное наследство мы оставляем нашим поколениям. Будет всё меньше людей, близких природе, ищущих в ней подлинного вдохновения и утешения, а ведь многие матери альные «блага», приобретаемые человечеством не в состоянии возместить потерь, наносимых миру этими приобретениями, ибо приобретают больше желудки, но не души» [Воробьев, 1959 1960]. В письме В. Ватагину Д. Горлов откровенно признаётся: «Необходимо пообщаться с милыми моему сердцу зверями и птицами, чтобы прийти в человеческое состояние ( ) Зверь куда благороднео, искреннее и менее коварен, чем человек» [Горлов, 1960-1968].

Подчёркивая то огромное значение, которое сыграли животные в развитии цивилизации В. Ватагин видит животный мир под знаком эволюционно-исторической трагедии и драмы органического макрокосма: «Никакой зверь не станет мучить или понапрасну убивать свою жертву. Какую, однако, иногда истребительную роль играет человек по отношению к животным! Какой огромный кровавый счёт могла бы предвя человеку природа за множество хищнически истреблённых прекрасных видов животных, соз данных ею!» [Ватагин В. А., 1957: 170]. «И когда убивают ради удовольствия, я всегда переживаю как потерю чего-то очень близкого, дорогого...» - говорит художник.

Смысл высказываний заключается в обосновании исторической роли животных в развитии цивилизации. Мастерами неизменно утвержда- ется мысль о том, что природа - животное человек - сложная, подвижная, исторически развивающаяся структура, где всё взаимосвязано, как в тончайшей нервной организации. Не может быть непроходимой пропасти между ними, как в отношении анатомии, физиологии, так и процессов в них происходящих. Всем ходом своих мыслей они подчёркивают, что без этого мира навряд ли возможно само существование человека.

Ватагин, Горлов, Ефимов, Воробьёв жили в то время, когда в обществе имела место ситуация затрагивающая вопросы сохранности живой при роды, бережного отношения человека к ней. Поэтому рассуждения анималистов на эту тему вполне закономерны. Как мы заметили, эти вопросы волновали А. Обера, который также говорил о ценности природы, о совершенстве животных, их разных индивидуальностях и весьма негативно высказывался об охоте. Скульптор осуждал всякие охотничьи забавы, от рук которых гибнет большое количество зверей, не понимал охотников, видящих в животном только сочетание костей и массы тела без «духовного проявления» и только «живые механизмы для охотничьего удовольствия». Все же его рассуждения об охоте имели частный характер и не были тенденцией, волнующей общество, что, в общем, не мешало скульптору создавать произведения с изображением охотящихся и борющихся зверей, исполненные сильного напряжения и экспрессии.

Другим было творчество анималистов XX столетия. Объясним их интерес к древним культурам. Мастера выделяют Древний Восток. По их мнению, там животное было в почёте. В. А. Ватагин впечат лялся искусством Древнего Египта, Д. В. Горлов, И. С. Ефимов - народным творчеством, которые во многом определяли их творческие искания. В. Ватагин указывает на значительное место, отводимое животному в древнем искусстве. Искус ство Ассирии, Китая, Египта созвучно идеалам художника. На примере многих произведений он увидел картину взаимоотношений человекживотное, которая импонировала ему. Живот ное как «зверобожество» [Рябинин, 1972: 372] явилось ярким выражением в древнеегипетской и ассирийской анималистике. Зверь-герой в образах могучего быка, льва заключён в широко обобщённые, выразительные формы монументально-декоративного искусства. Мастера впечатляло орнаментальное искусство скифов, где 
животное в переплетениях декоративной композиции превращено почти в геральдический знак и своими условными и одновременно реально узнаваемыми формами источает некую магическую силу. В народном искусстве художники также наблюдали большой интерес к животным. Звери и птицы были неотъемлемой частью человеческой жизни. Анималистические изображения по своей сути условные и весьма примитивные, содержали ценное качество - одухотворённость. Животные одухотворялись мыслями, чувствами настроением человека, они были едины с ним.

В своих воспоминаниях И. Ефимов обращает внимание читателя на произведения искусства народов Востока, а также на памятники русского народного творчества, которые, по его мнению, «являют собой образцы действительно высокого, вечно вдохновляющего искусства» [Ефимов, 1977: 423]. Именно здесь скульптор ощущае природные основы анималистического образа Д. Горлов также склонен опираться на народное творчество. В письме Е. Н. Ватагиной он чётко определяет свою направленность: «Моей основой основ была природа и народное искусство» [Горлов, 1960-е].

Об этих культурах и о роли животных в них повествовали многие авторы. Boria Sax [Boria Sax 2001: 298], Sian Lewis, Lloyd Llewellyn-Jones [Boria Sax, 2001: 298] говорят о важности понимания животных для современного человека. Они охватывают широкий диапазон времени, сосредотачиваясь на древних культурах Средиземноморья а также значимости священных животных династи ческого Египта, о чём писал Ватагин. Waldau Paul, Kimberley Patton [Waldau Paul, Kimberley Patton 2009: 686] отмечали, что животные присутствовали во всех мировых религиях и отражали религиозные ритуалы, представляя целые системь верований, мифов. Их изучение способствует более глубокому пониманию человеческого соци ума в целом.

Выделение именно этих периодов в развитии анималистики обусловлено взглядами художни ков на мир животных, на самое мастерство изо бражения. Символическое восприятие образа определённая условность изобразительного языка - эти качества импонируют мироощущению художников. В мировоззренческом плане в ракурсе современности анималистический образ прошлого весьма актуален. Значение же анимали стического искусства XX столетия в том и состоит, что оно полнее всего смогло воссоздать панораму природного мира, ассоциируемого в широком смысле с «картиной мира». В XX веке взгля на мир природы и искусство, станковая графика, скульптура и живопись, монументально-декоративные работы, пластика малых форм - суть грани одной художественной концепции мастеров. Эта концепция философского настроя. Художественные произведения приобретают многоликий характер. В них можно проследить столько разных оттенков одной темы, неожиданных творческих решений, включающих традиции и стиле вые направления прошлых эпох. Здесь говорить о видовых и даже жанровых границах не приходится. Современное анималистическое искусство ярко демонстрирующее разнообразные изобразительно-пластические варианты, продолжае отражать экологическую тему, которая в современном мире становится ещё более актуально значимой. В современном анималистическом ис кусстве оказывается важной та отрасль биологии которая изучает общие закономерности взаимодействия живой и неживой природы, в частности, проблемы влияния современной цивилизации на окружающий мир.

\section{Заключение}

В заключение отметим, что мировоззренческие принципы художников-анималистов, основанные на понимании, любви и преклонении перед миром живой природы, их приверженност к традициям древнего искусства, в котором часто изображалось животное, а также професси ональные знания, в совокупности определили творческое лицо художника-анималиста XX века, ориентированного на запросы времени. В своих высказываниях анималисты раскрыли целостную картину взаимосвязи природа - человек места человека в этом мире. Их взгляды, сужде ния, учения представляют интерес и полезны как для специалистов, так и для широкой ауди тории. На этом пути, выступив в своём самостоятельном жанровом качестве, как модальность новой тематической реальности, жанровое начало которой нашло выражение в разных видах изобразительного искусства, оно сыграло несомненную роль в широком мировоззренческом смысле как ценностный фактор взаимодействия природы-человека и более узком как изобразительная тема времени

Тема природы и животных продолжает быть актуальной в наше время, к тому же воспита- тельно-образовательный аспект анималистики очевиден для всех поколений, прежде всего, для детской и юношеской аудитории.

Подтверждения. Статья написана в рамках Программы стратегического академического лидерства РУДН.

БИБЛИОГРАФИЯ

1. Тиханова В.А. Лик живой природы: Очерки о советских скульпторах-анималистах.—Москва: Советский художник, 1990.- 238 с.

2. Ватагин В.А. Воспоминания. Записки анималиста Статьи. -Москва: Советский художник, 1980. - 213

3. Ватагин В.А. Изображение животного: Записки анималиста. -Москва: Искусство, 1957. - 170 с.

4. Ефимов И.С. Об искусстве и художниках.-Москва: Советский художник, 1997.- 423 с.

5. Caspari Elizabeth. Animal Life In Nature, Myth and Dreams. - Chiron Publications, 2003. - $350 \mathrm{p}$.

6. Peterson Anna. Being Animal: Beasts and Boundaries in Nature Ethics. - Columbia University Press, 2013.$236 \mathrm{p}$

7. Hurn Samantha. Humans and Other Animals: CrossCultural Perspectives on Human-Animal__-Pluto Press, 2012.-266 p.

8. Кутепов Н. Великокняжеская царская охота на Руси с X по XVI век: Исторический очерк // Экспедиция заготовления государственных бумаг_- Издание 2.-Т. 1-3.-С.-Петербург, 1896.- 211 с.

9. Кутепов Н. Царская охота на Руси царей Михаила Фёдоровича и Алексея Михайловича. XVII век: Исторический очерк - Издание 2-Т 2-С--Петербург, $1898 .-315$ c
10. Кутепов Н. Императорская охота на Руси конца XVII и XIX веков: Исторический очерк // Экспедиция заготовления государственных бумаг.-Т. 4. - С.-Пе-

ия. Май 1917 г. // РГАЛИ. Ф. 1956. Оп. 2. Ед. хр. 13

B. A. $1959-1960$ // РГАЛИ. Ф. 3022. Оп. 1. Ед. хр. 103.

13. Письма Горлова Д.В. Ватагину В.А. 1960-1968 // РГАЛИ. Ф. 3022. Оп. 1. Ед. хр. 107.

14. Письмо Горлова Д. Ватагиной Е.Н. (с упоминаниxp. 191

15. Sax Boria. The Mythical Zoo: An Encyclopedia of Animals in World Myth, Legend, and Literature.-ABC CLIO, 2001.- $298 \mathrm{p}$.

16. Lewis Sian, Lloyd Llewellyn-Jones. The Culture of Animals in Antiquity: A Sourcebook with Commentaries. Routledge. - London, 2018. - $778 \mathrm{p}$

17. Waldau Paul, Kimberley Patton. A Communion of Subjects: Animals in Religion, Science, and Ethics.Columbia University Press, 2009.-686 p.

18. Рябинин Б.С. Зверопоклонник Ватагин // Вглядываясь вжизн. -С ердлолск: Средне-Уральское книжное издательство, 1972. - 372 c. тербург, 1911. - 328 с 


\section{THE IMAGE OF CHINA IN THE CORRESPONDENCE OF CATHERINE II}

Summary: In 1762, Catherine II (1729-1796), Catherine Grand, as Voltaire called her, an extraordinary woman who was destined to undergo many reforms and establish Russia's place in the world, ascended to the Russian throne. Her reign coincided with the reign of Emperor Qianlong (1711-1799), one of the most enlightened monarchs in Chinese history; during his time, the empire achieved many military victories and brilliant achievements in the arts.

By the time of Catherine's accession to the throne, relations between the two countries were very strained. Meanwhile, the age of Enlightenment, the century of the ardour for the philosophy and art of China, began in Europe. On the one hand, Catherine was influenced by the ideas of the West; on the other hand, she constantly had to regulate conflicts on the Russian-Chinese border, the reason for which was most often the question of extraditing Mongols and Dzungars to the Chinese who were fleeing within Russia. The purpose of this article is to determine what image of China the Russian empress formed and how she spoke about this country in her correspond

The reign of Catherine II (1762-1796) coincided with the era of Enlightenment in Europe and the reign of Emperor Qianlong in China (1736-1795). This reign was marked by the adoption of important political, legislative and administrative measures, achievements in the field of science, literature and art, a number of military celebrations, a constant increase in the strength of the popular forces and the state glory of Russia.

It is known that as a child, Catherine received minimal primary education. "Well," she said once. "Maid Kardel could not have taught me better. She was an old Frenchwoman and educated me enough to be married to one of our neighbours" [2, p.XXIII] However, like Peter I and most of the great people Catherine strove for self-improvement. She soon
Catherine II wrote a lot. To do this, first, it is necessary stand her interests and habits. To understand what issues she had to resolve, one also needs to know the state of Russian-Chinese relations in the second half of the 18th century. Finally, the article gives a general description of Catherine II's correspondence with various high-ranking persons, among whom Jean d'Alembert, Diderot, Voltaire, Friedrich Melchior Grimm (Franco-German publicist, artist and literary critic), Swiss scientist and philosopher Johann Georg Ritter von Zimmermann, Madame Geoffrin and Madame Bielke can be named. The letters she received very often contained diplomatic news, dynastic problems, court gossip; her answers were, for the most part, semi-official journal notes. It is noteworthy that de spite the extensive correspondence conducted by Catherine the Great, she practically did not touch upon the issues of China, except for letters to Voltaire, who, as you know, admired China and tried to learn more about from the words of the empress.

Keywords: China, Catherine II, Qianlong, Enlightenment Voltaire, correspondence

made up for the shortcomings of her upbringing becoming on a par with the most educated people of her century. After the wedding, she, according to her, did nothing but read. "Never without a book and never without grief but always without entertainment," this is how Catherine outlined her pastime at that time $[7$, p.530]. Soon she became briefly familiar with the works of modern and ancient philosophers and politicians.

Having fallen in love with her second homeland with all her heart, Catherine studied its language history, and her people's way of Ife. She made a significant contribution to Russian historiography. "The science of Russian history begins with Catherine II" [2, p. VIII]. Many Russian chronicles were first published during her reign, making it possible

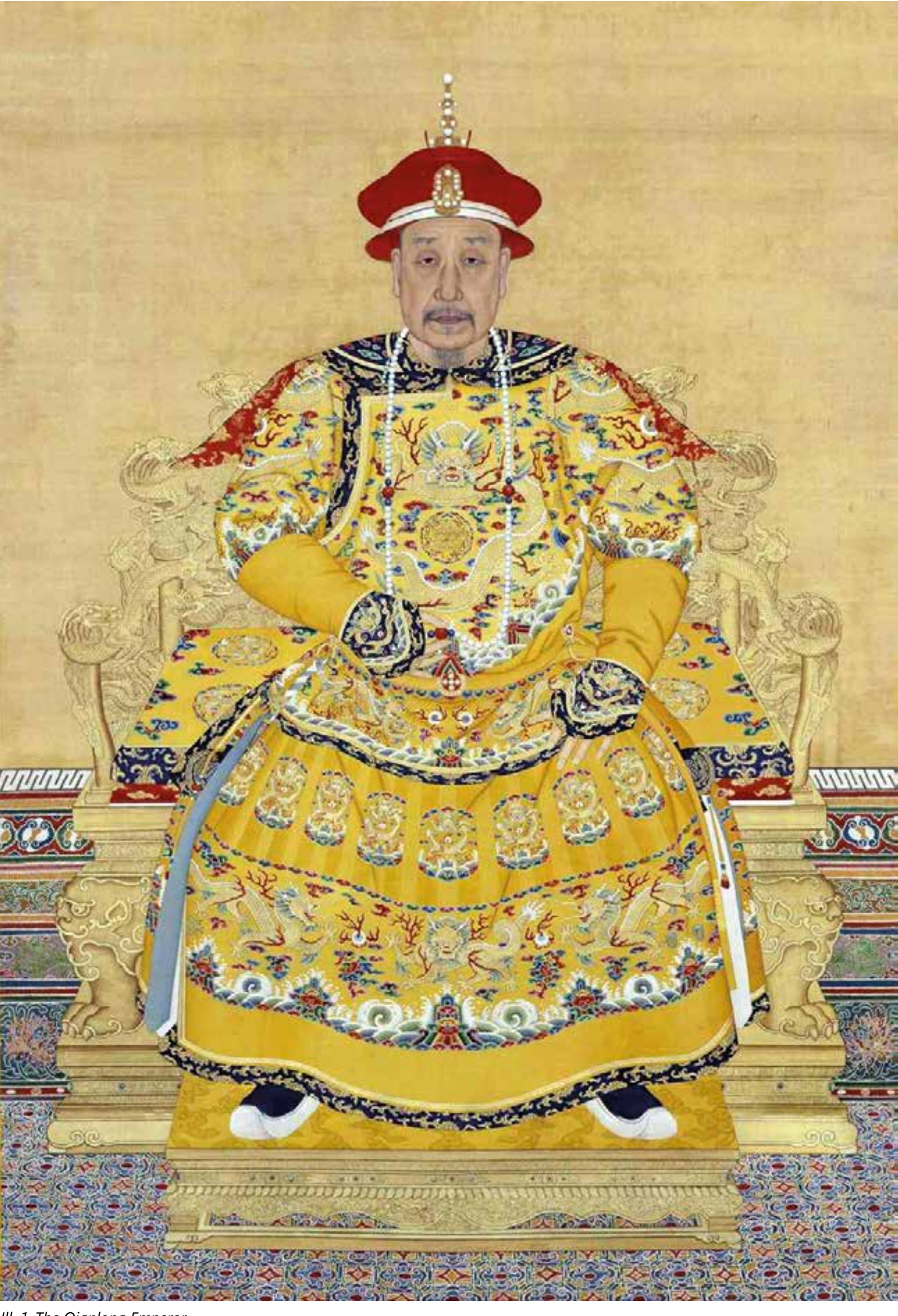

II. 1. The Qianlong Emperor 
for scientists to compile Russian history. Catherine herself was among the Russian historians. While be ing the Grand Duchess, she devoted several hours every day to reading history, making extracts and notes later included in her Notes on Russian Histo$r y$, which appeared first in the Sobesednik, and then were published in a special edition. "The Empres explains their publishing, on the one hand, by the fact that every nation needs to know its own history and geography more than foreign, and, on the other hand, that 'they are not composed for young people at a time when books are published in foreign languages under the name Russian History, which can be called rather biased creations since each page serves as evidence of what hatred it is written with each circumstance is not only presented in a perverse form, but a malicious talk is added freely to them'" $[2$, p.X]. This proves that Catherine II protected the honour of Russia even in the field of science.

Being the most educated woman of her time, the Empress could not ignore the ideas of Enlightenment, among which was the idea of an "enlightened monarch". "Like the French feudal lords, Catherine II and her courtiers were looking for a substantiation of the nature of despotic power in the way of life, laws, philosophy and history of China. $<\ldots . .>$ No wonder Catherine, by a special decree, commanded to translate the Criminal Code of the Qing, where the one-man rule of government was glorified, and the privileges of the Manchu nobility were legalized" [14, p.67]. "Catherine is reading Essai sur les Moeurs e Esprit des Nations, Le Siècle de Louis XIV, Dictionnaire Philosophique de la Chine. And the play L'Orpheline de la Chine (1755) was even supposed to be staged in the court Hermitage Theater by analogy with its staging in front of the Chinese Pavilion in the Sanssouci Park in Potsdam. By the highest order, Alexei Leontiev, one of the first European sinologists, translated from the Chinese language in the 1770s. Moreover, most of the translations "were paid by the Cabinet" [11, p.73]. Interest in China was fueled largely by communication with Voltaire, who admired China and used Chinese history for sharp philosophical polemics. Voltaire spoke most fully about China in An Experience of Morals, Philosophical Dictionary, Papers of Jean Neslier and an article "On the Expulsion of the Jesuits". "Voltaire notes that if a philosopher wants to talk about the events of the world, he must first cast his eyes to the east 'the cradle of all arts, to which the West is wholly obliged'" [1, p.317]. Catherine followed Voltaire's in- structions. She not only studied the philosophy and literature of China but also began collecting objects of Chinese art. In Oranienbaum, a Chinese Palace appeared, in Tsarskoye Selo - Chinese buildings, and in the Winter Palace - Chinese rooms.

In terms of Catherine's foreign policy, the precarousness and volatility that had characterised Russian politics before her reign gave way to decisive action. "Instead of friendship with all the powers, during 34 years of her reign, she ruined friendship between Russia and almost all the major states of Western Europe and brought one of the bloodiest reigns to our history, waged six wars in Europe and before her death, was preparing for the seventh with revolutionary France" [7, p.563].

Not everything was calm in neighbouring China either. "From 1685 to 1792 , the Manchu emperor fought 11 wars that lasted more than 50 years in total. From 1721 to 1795,12 major uprisings took place in China, mainly raised by national minorities. It took almost 30 years to suppress them. Externa and internal military actions often took place simultaneously" [12, p.145]

Having come to power, Catherine II was engaged in settlement of relations with China with special at tention. Until the mid-50s of the 18th century, friendly ties remained between Beijing and St. Petersburg. However, the situation changed dramatically after the conquest of Dzungaria, the flight of a part of the Oirats, and then of the sovereign prince of the Oirat Khanate, Amursan, to the Russian borders, after the transition of individual Mongolian principalities to the Russian side [12, p.144]. The main reason for the difficulties that arose was mainly the issue of handing over the Mongols and Dzungars, who were fleeing within Russia, to the Chinese. On the other hand, the Russian government could not become an accomplice to the atrocities awaiting defectors in China. As a result, the Chinese government not only did not allow Russian caravans to cross the borde but even strictly forbade its subjects to maintain relations with the Russians [10, pp.28-29].

In 1762, the Empress sent Captain I. Kropotov to notify Emperor Qianlong of her accession to th throne and settle border issues. "The Bogdykhan received the Russian ambassador; however, they treated him so dryly that he could not achieve anything to restore trade" $[10$, p.30].

Relations between Russia and China were not easy. For example, F. Martens believes that "from the very beginning of Russia's relations with China, the Chines had confidence in them. They have always strictly distinguished Russians from subjects of other European states, whom they call foreigners and even 'overseas devils'" [10, p.2]. However, events showed that the attitude towards the Russians was not always trusting. According to Martens, the reason for this was "the unfortunate consequence of the treatment that the Middle Empire was subjected to by other civilised powers, and the unjust wars waged against it" $[10, p .73]$. The emergence of troubles was also facilitated by the fact that Russia was mentioned as a vassal state to the Bogdykhan in Chinese works on geography $[10$, p.7]. "Such a view was instilled in the Bogdykhans and was reflected when they received Russian envoys. For a long time the Bogdykhans sincerely saw in them only those sent from their subservient people and demanded worship and tribute humiliating for the Russian dignity. Those Russian people sent to establish trade relations with China or on border affairs who did not agree to humiliation did not achieve the goal of their mission either" $[8$, p.76]. This attitude towards Russia as a subservient people was reflected in Russian-Chinese correspondence. "The Russian side, in a contractual way confirming its readiness to correspond with the Lifan Yuan (the Chamber for Vassal (!) Territories), as it were, recognised itself as a 'vassal' of the Qing Empire. However, on the other hand, from now on, with this appointment', 'many contradictions that arose during the correspondence of the tsars were removed therefore, the process of Russia achieving its goals was facilitated"' [9, p.107].

Since 1763, relations between Russia and Chin had taken an even worse turn. In 1764, all official correspondence with the Chinese government was terminated since Empress Catherine II could not respond to the daring notes of the Lifan Yuan without losing her dignity [10, p.30]. In August 1764, ag gravated relations with the Chinese and because of the "threatening" situation adopted by the Chinese forced Catherine to draw up an emergency conference with Prince Golitsyn, Counts Panin, Chernyshev, Minikh, Olsufiev, Neplyuev and Vilboa in August 1764 One of its aims was to send a military expedition to the Amur $[15$, p.60]. In the same 1764, she established a committee of competent persons to study the terms of trade with China. Based on its results, it was decided to abolish state trade with China, hand it over to Russian merchants, and transform the entire administration of Siberia to improve relations with the Heavenly empire [10, p.29].
From 1762 to 1768 , bargaining ceased and resumed incessantly until, in 1768, Captain Kropotov was again sent to Kyakhta to resolve disputes over border and trade matters. "After a long debate, the plenipotentiaries signed a separate act or addition to the treatise of 1727 on October 18, 1768" [10, p.30]. Since 1768 , after seven years of strife, seven years of peace came - the longest peace since 1719 [15, p.62]. The next break in relations with the Chinese occurred in 1778 (lasted until April 2, 1780) ove some Olot, Russian subjects who plundered Rus sian merchants and fled to China [15, p.63]. In 1785, a new break occurred, which lasted until April 24 1792. Several robbers of Russian citizenship, led by Uladzai (Ulagai), were caught at the border. The Chinese demanded their execution at the crime scene and the Irkutsk governor only exiled them. "As a result of this, in 1785, the tribunal complained that the governor willfully exiled them to distant exile after only beating Ulagai and others who had previously staggered" [15, p.63]

Against the background of all these events, it was interesting to know how the Russian empres responded about China in her correspondence with foreign correspondents since, as it is known, she wrote a lot. She once remarked to her secretary Gribovsky, "you cannot even live one day without writing" [2, p.XIII]. The reason for such literary activity was not only a property of her character but also the influence of the spirit of the time when imitation of the great minds of that century was adopted. It is when the extensive correspondence began. The empress corresponded first with D'Alembert Diderot and Voltaire, then with half-German, halfFrench Grimm, then with Hanoverian scholar Zimmermann, with Madame Geoffrin, who lived in Paris and had a literary salon, which was considered a literary centre and the supreme aesthetic court, Mad ame Bielke, who during Catherine's childhood was close to her mother and lived in Hamburg. "These relations had a multifaceted purpose: on the on hand, Catherine wanted to constantly know about everything that happened in the West and what was said about her; on the other hand, knowing the extensive connections of these persons, as well as their authority and influence on public opinion she wished, with her letters to them, to disseminate true, or at least which agreed with her views, information about Russian affairs, to refute slander and false talk, which were incessantly dismissed by the enemies of Russia" [2, p.XIV] 
The letters she received very often contained political messages; her answers mainly were semi-official journal notes: there were bulletins about campaigns, and militant articles, and even "real manifestos, as in a letter dated January 21,1791 , written to Zimmermann but intended for the Berlin court, which had to be pacified, giving it at the same time advice no to interfere in Turkish affairs. Many of the notes to Voltaire were intended to shake the position of the Duke of Choiseul. Catherine herself once confessed that to Khrapovitsky" [5, pp.385-386]

When familiarising with her correspondence with various persons, which amounted to five volumes published by the Imperial Russian Historical Society, it is striking how much she wrote about European affairs and practically nothing about relations with China, which, in general, should be regarded as a positive phenomenon. Voltaire and then Prince Charles de Ligne were her correspondents with whom she talked about China. Acquaintance with Voltaire's works began soon after she arrived in Russia, when she, on the advice of Prussian envoy Mardefeld, refused to spend idle time and started reading $[2, p . X$ VI]. "Since 1746, since the time that I have My own time, I feel your great favour. Before this era, I had not read any books other than novels; however, by chance, your works fell into my hands. Since that time, they constitute My usual reading, and I have not looked for other books, except those that are so well written, and in which there are just as many useful things," [13, pp.4-5] she wrote in her first letter to Voltaire.

In the correspondence between Catherine II and Voltaire, which lasted from 1763 to 1777 - until Voltaire's death, many questions about Russian domestic and foreign policy were raised. Polish historian K. Valishevsky (1849-1935) has interesting lines. "She dreamed of building a Ferney Palace in Tsarskoye Selo, reproducing a completely external and internal view of the famous dwelling - a room where the philosopher thought and wrote, even the landscape on which his gaze rested. At the same time she would never agree to publish her correspondence with him: her letters were too badly written his - too flattering for her and disrespectful for other rulers. And since this correspondence was no approved by many, and the too suspicious highe clergy saw in it almost a scandal, she simply began to deny it. She could not forbid Voltaire to write to her - so many people wrote to her! However, she did not answer him; she rejected all his attempts to involve her in a correspondence that would be unworthy of the Empress of All Russia" [5, p.213].

"In her frank conversations with Grimm, she found that 'their tone is very ordinary'" $[5, p .391]$. This by no means characterises Catherine as an unwise ruler. As already mentioned, Catherine was very well-read and protected the interests of Russia in everything "In her reception of foreign ambassadors, in her relations with anyone, every word, her every step showed an extraordinary tact and skill to produce the desired impression unmistakably. Catherine was as subtle a diplomat as a skilful administrator" [2, p.XXIV]. Catherine tried to follow modern fashion. "Fashion was to treat everything casually, ironically, to make ridicule even in the discussion of the most serious issues. Voltaire taught his pupil all this; she was delighted with this direction and applied it at random, like a capricious, courageous woman, paying little attention to rules and decency" [5, p.391].

The relationship between an ambitious, politically powerful woman and a highly gifted, universally educated philosopher, one of the greatest authorities in French Enlightenment, was mutually beneficial. Catherine realised that letters to Voltaire would become known to his friends and treated them like messages to the intelligentsia of Europe. "For Voltaire, what could be more flattering than having another royal apprentice in the person of the reigning monarch? He addressed her as 'Semiramis of the North', 'Saint Catherine' and 'Our Lady of St. Petersburg'. In response, she showered him with sable furs and jewelled snuffboxes and sent diamonds to Madame Denis. However, it was a relationship that flourished at a distance; despite the intimacy of their correspondence, the Empress and the venerable elder never met" [16, pp.335-336].

As Valishevsky notes, the empress's letters can be divided into three categories: letters written by her, composed by her and written by her order. The former are the rarest $[5, p .386]$. Letters to Voltaire in his opinion, were almost all written to order and were a kind of literary works. "I write with my own hand only to those people who, I believe, love me and whom I value; it is impossible for me to pursue a wit, a selective presentation", she wrote to the Duke de Ligne, "therefore, I do not write at all for this to be published, and nothing seems to me as vulgar as what I wrote when I come across it in print" $[4$, p.96]. She copied letters to the Ferney patriarch with her hand, retaining her characterstic manner of writing: "a well-known familiarity playful good nature and sincerity, even originality of thought and expression", skillfully handled by the suppliers of French or Russian prose - Shuvalov, Kozitsky or Khrapovitsky, who in turn served as secretaries to the empress [5, p.387].

As it is known, in his work Experiments on Mor $a l s$, Voltaire initially, before adding the introductory part, began his presentation of world history from the East - from China, "where civilisation firs emerged, while the West was in complete barbarism" [6, pp.173-174]. In contrast to ancient Israel and the states of modern times, for Voltaire, it was a country of acquired wisdom, justice and in ner peace. "Although the Chinese have not excelled in the sciences, they are the world's first people in morality and culture (police). It is explained, according to Voltaire, by the fact that the head of the state is a sage - an emperor, surrounded by philosophers - Mandarines. They profess Confucianism which represents a purely philosophical religion deism. The masses of the people, it is true, will become stiff with gross religious prejudices; however, the emperor and the Mandarins wisely use opportunities to undermine the people's lower beliefs and cults. Starting from sentimental, idealised descriptions of travellers and missionaries, Voltaire created a moralising fable and a lesson to Europeans from Chinese history" [6, p.174]. It is natural to assume that when he corresponded with Catherine, Voltaire could not help but inquire about Russia's neighbour, China, in which he had such an interest.

First the philosopher tried to start a conversation about the literary talents of the Chinese emperors. Thus, in a letter dated May 26, 1767, Voltaire wrote: "Your neighbour, the Chinese Emperor, Kamgi, asked a Missionary if it was possible to write poetry in European languages? He doubted it" [13, p.25] However, Catherine decided to leave this remark unanswered. Three years later, in a letter dated November 20, 1770, Voltaire again tried to touch upon the topic of China: "You have two neighbours who compose poetry, namely the King of Prussia and the Emperor of China. Frederick has already composed to you in praise, I have and now expect it from KienLong" [13, p.133]. And again, there was no answe to these lines. In the following letter, dated November 26, Voltaire again mentioned the bogdykhan "Long live the Chinese Emperor! He composes poetry and lives in peace with the whole world!" [13, p.134] And again silence in response. In the next letter, dated December 22, 1770, Voltaire already wrote impatiently: "Most Merciful Empress! My passion is becoming somewhat unhappy. I have no news of either Your Imperial Majesty or my enemy Mustafa. All that I can still do is to inform you of my boring correspondence with the Chinese Emperor, your neighbour" [13, p.140]

As mentioned above, the years from 1762 to 1770 were filled with the solution of numerous troubles that arose on the Russian-Chinese border, about which Catherine preferred not to speak. And finally, in a letter dated December 23, 1770 she wrote about China: "Ah, My Lord! You have praised China so much that I no longer dare not approve of the poems composed by that country's Sovereign. However, in the affairs that I have with this Government, I could present such evidence, which would greatly diminish the generally accepted good opinion of their enlightenment and make one think of them as gross ignorant; but why should one offend their neighbour? I, imposing silence on myself, marvel without any contradiction at the narratives sent from the confessors who are there. What is more, it must be said that I am dealing with the rule of the Tatars, who conquered China, and not with the natural Chinese [13, p.143]

Then, in her next letter dated January 12/23, 1771 Catherine continued: "It seems to me that you can be satisfied with the year 1770 and that you still do not have a reason to praise My neighbour, $\mathrm{Ch}$ nese Emperor, despite the poems and your revived love for him (please do not get angry), I do not find meaning in it. You say that jealousy alone makes $M$ speak there; far from it; I will not trade my Roman nose for his flat face; nor do I envy his talent for writing bad poetry; I only like to read yours alone. The epistle written to My rival is beautiful. Immediately upon its receipt, I showed it to Prussian Prince Henry, and he was equally pleased with it. If fate pleases that I, in the judgment of you, have a rival then I pray to the Most Holy Mary that this is someone else, not the Chinese Sovereign; for I am angry with him" [13, p.148].

Then, apparently, relations with China becam better as the empress wrote calmer two months later (letter dated March 3/14, 1771): "Since my neighbour, Chinese Sovereign, eliminated some unjust oppression, his subjects entered into trade with me. In the first four months since this bargaining opened, they have exchanged goods for three million rubles. My neighbour's factories are busy making wallpaper 
for me, and he asks Me to deliver him sheep and bread" [13, p.156].

In the following letter (dated March 5/15, 1771), Catherine gave a more detailed description of relations with China: "You want me to tell you something about the ignorance and rudeness of the Chinese, which I mentioned in one of my letters. We are neighbours, you know that. Our borders on both sides are inhabited by Tatars and idolaters who feed on cattle. These peoples are overly prone to plunder. They kidnap each other herds, and even people (often out of the same vengeance). The resulting quarrels were stopped by the commissars sent to the borders. The Chinese are such great snitches that it is as difficult to resolve a minor problem with them it is to drink the sea. It happened more than once that being satisfied in everything, they demanded bones after the dead not to give them any honour but to abuse them. For ten years, such stinginess served them as an excuse to suppress trade; I say with the pretext that the real reason was that his Chinese Majesty gave the bargaining with Russia to one of his Ministers in Monopoly. The Chinese and the Russians were equally unhappy, and as it is challenging to interrupt any exchange bargaining, both peoples exchanged their goods in those places where no customs outposts had been established, preferring their needs to dangers. When we gave them detailed information about the state of mutual relations, in return, we received a great heap of papers, written so randomly that after reading them from beginning to end, we could only see ignorance and rudeness instead of meaning and politeness. From us, they were told that such words were not suitable for us as it is considered offensive in Europe and Asia. I sense your objection. You will say that the Tatars, who seized the Chinese State are much worse than the ancient Chinese; I agree! However, it will remain indisputable that the winners did not learn politeness from the defeated, and these, in the end, will be forced to submit to the prevailing customs" $[13, \mathrm{p} .160]$.

It is what little the Empress allowed herself to say about China. In addition to discussing Emperor Qianlong's poems and trade with China, anothe topic of correspondence was the possibility, through Russian merchants, to sell watches produced by Voltaire's factory to China. "To help the people in his village, he built a watch factory and then persuaded all his friends in Europe to buy their products $<$...> By 1777 , this once small, impoverished village of 49 people turned into a prosperous town of 1200 people" [16, p.334].

Catherine II was no exception - Voltaire addressed her with a lengthy speech, very reminiscent of an offer to place an order with him. "It seems to me, if your Nivkh Tatar-Chinese were quick-witted they could buy inexpensive watches and sell them in their State with great profits. The people of $\mathrm{Ge}-$ neva have an Office in Canton and receive a substantial profit there. Is it possible to establish one on your border as well? My colony would make silver watches at the cost of 12 to 15 rubles and gold watches priced from 50 to 40 rubles. Moreover, it would undertake to exhibit them for 200,000 rubles every year, if necessary. However, it seems to me that due to the distrust and suspicion of the Chinese, it is hardly possible to enter into a big bargain with them, requiring compliance and frankness" [13, p.167].

The empress did not refuse and bought watches for three to four thousand rubles. However, Voltaire soon sent her a second batch of watches, hastening to apologise: "It happened from the too great zeal of the 'colonists'"- it is not his, but their fault. "However, the bill is only 39,238 French livres, which is half the price in London, Paris and even Geneva. All benefits are provided upon payment." - "Well", answered Semiramis, "but this is the last time". She sent 39,238 livres, along with a bulletin about the latest exploits of the Russian troops, about which the person who is most read in the whole world should notify Europe" [5, p.202].

Further, in a letter dated May 24 / June 4, 1771 Catherine expressed her consent to the proposal for the sale of watches. "I think it would be possible to ship their products to China; however, it would require some educated merchant who would know the customs of trade with Kyakhta - the place bordering Russia where this trade is made. $<\ldots>$ At my command, the customs tariff for trade with China is being revised to alleviate it in order to facilitate import and export. The prices that you set are so moderate that the products of your production can have great sales" [2, p.103].

Voltaire, apparently, was inspired by these lines since, in one of his letters, he again tried to offer Catherine not watches but a wall clock. In a letter dated December 3/14, 1771, Catherine suggested contacting "some local office where there are Geneva residents who can easily find a means to deliver clocks to the Chinese border" $[2$, p.199].
The last letter to Voltaire was written on December 4 / November 23, 1777; on May 30, 1778, the philosopher passed away. For 14 years of correspondence, Voltaire and Catherine never met.

Since that time, in her letters, Catherine had not touched on Chinese affairs. Only sometimes, in the correspondence with Prince de Ligne, which began in 1781, she casually talked about the Chinese emperor. Thus, in a letter to Prince de Ligne about the memory he left about himself in Russia (July 11, 1782), she wrote: "Neither my dear friend, the Byzantine Emperor, nor my good neighbour, the Emperor of China, is unable to prevent me from reading your letters, infinitely more pleasant than their letters despite their high rank in the almanacks" [3, p.210]. Or, as in a letter about the states neighbouring Russia (November 16, 1790), she reported: "The Beijing newspaper says that my Chinese neighbour with small eyes, about whom you speak so honourably, observes with true approximate accuracy all the countless rituals, to which he is subordinate" $[4, p .125]$. It is the little that the empress allowed herself to say about China in her correspondence with the prince.

Summing up the above, we can say that Catherine's views on China were greatly influenced by Voltaire, with whose works she was well acquainted and with whom she had corresponded for fourteen years. Under Catherine, many translated materials on the topic of philosophy, state structure, and customs of China appeared in Russian periodicals. However, reading the papers from the Chinese government, she realised that everything that Voltair admired was somewhat related to the ancient Chinese culture, the bearer of which the Han nationality was. Also, she had to deal with the Manchus who seized power. They came from the northeast and their customs and traditions were somewhat different. The situation on the Russian-Chinese border was turbulent. During the reign of Empress Catherine II (1762-1796), trade relations with China ceased three times, namely in 1762 for six years, was challenging to correspond with the Chinese court. Nevertheless, the empress preferred not to expand on relations with China in letters to he numerous European correspondents, which she wrote almost every day. The exception was letters to Voltaire, to whose comments she had to answer and which, in the opinion of Catherine herself, were poorly written. This restraint in correspondence can only be regarded as a positive phenomenon indicating that Catherine protected state interests concerning China, preferring not to interfere with Western states in relations with her eastern neighbour. 
1. Alekseev, M.P. 1987. Pushkin i mirovaya literatura.

2. Bumagi imperatritsy Ekateriny II, khranyashchiesya v gosudarstvennom arkhive Ministerstva inostrannykh del. - Vol. 3 (1762-1774), St. Petersburg: Tipografiya Imperatorskoi akademii nauk, 1874.

3. Bumagi imperatritsy Ekateriny II, khranyashchiesya v gosudarstvennom arkhive Ministerstva inostrannykh del._- Vol. 4 (1774-1788). Sbornik imperatorskogo russkogo istoricheskogo obshchestva. - Vol. 27, St. Petersburg: Tipografiya Imperatorskoi akademii nauk, 1880.

4. Bumagi imperatritsy Ekateriny II, khranyashchiesya v gosudarstvennom arkhive Ministerstva inostrannykh del._ Vol. 5 (1789-1796). Sbornik imperatorskogo russkogo istoricheskogo obshchestva, Vol. 42, St. Petersburg: Tipografiya Imperatorskoi akademii nauk, 1885.

5. Valishevskii, K.F. 1911. Vokrug trona: Ekaterina II, Moscow.

6. Vol'ter: Stat'i i materialy / Pod red. akad. V. P. Volgina; Akad. nauk SSSR, Moskva; Leningrad: 2-ya tip. Izdatel'stva Akademii nauk SSSR, 1948.

7. Klyuchevskii, V.O. 2003. Russkaya istoriya. Polnyi kurs lektsii v 2-kh knigakh. - Kniga 2, Posleslovie, kommentarii A. F. Smirnova, Moscow.

8. Kuropatkin, A.N. 1913. Russko-kitaiskii vopros. - St. Petersburg: Tip. Tovarishchestva A.S. Suvorova «Novoe Vremya».
9. Lapin, P.A. 2012. "Rossiisko-kitaiskaya mezhgosudarstvennaya perepiska kak vid vneshnepoliticheskoi deyatel'nosti: kitaiskii aspekt (pervaya polovina XVIIvtoraya polovina XIX v.)", Rossiya i Kitai: problemy strategicheskogo vzaimodeistviya: sbornik Vostochnogo tsentra, no. 12, pp. 106-114.

0. Martens, F.F. 1881. Rossiya i Kitai, St. Petersburg: Tip. I. Gabermana.

11. Men'shikova, M. 2016. "Zdes' «vse dyshalo ambrozie Azii»", Voobrazhaemyi Vostok: Kitai «po-russki». XVIIInachalo XX veka, Moscow, pp. 66-73.

2. Nepomnin, O.E. 2005. Istoriya Kitaya: Epokha Tsin XVIII-nachalo XX veka.-Moscow.

3. Perepiska rossiiskoi imperatritsy Ekateriny II i gospodina Vol'tera, prodolzhavshayasya s 1763 po 1778 god Perevel s frantsuzskogo Ivan Fabiyan; S portretom imperatritsy i Vol'tera, Moscow: V vol'noi tipografii Gariya i Kompanii, 1803.

14. Skachkov, P.E. 1977. Ocherki istorii russkogo kitaevedeniya, Moscow: Izdatel'stvo «Nauka», Glavnaya redaktsiya vostochnoi literatrury.

15. Trusevich Kh. 1882. Posol'skie i torgovye snosheniya Rossii s Kitaem (do XIX veka), Moscow: Tipografiya G. Malinskogo.

6. Robert, K. 2012. Massie. Catherine the Great: Portrait of a Woman, New York: Random House Trade Paperbacks.

Наталья Геннадьевна Сураева

Кандидат искусствоведения

Институт истории и культуры Хэнаньского университета (Кайфэн)

e-mail: Ikshbaie@126.com

Кайфэн провинция Хэнань КНР ORCID0000-0001-8162-1906

DOI: 10.36340/2071-6818-2021-17-4-62-78

\section{ОБРАЗ КИТАЯ В КОРРЕСПОНДЕНЦИИ ЕКАТЕРИНЫ II}

Аннотачия: В 1762 году на российский престол восходит Екатерина II (1729-1796), Catherine le Grand как её называл Вольтер, необыкновенная женщина, которой суждено было проделать много реформ и утвердить место России в мировом пространстве. Время ее правления совпало с правлением императора Цяньлуна (1711-1799), одним из самых просвещенных монархов в истории Китая, при котором империя добилась Многих военных побед и блистательных достижений в искусстве. К моменту вступления Екатерины на трон отношения между двумя странами были очень натянуты. Между тем в Европе это был век Просвещения, век увлечения философией и искусством Китая. С одной стороны, Екатерина испытывала влияние идей Запада, с другой, - ей приходилось постоянно регулировать конфликты на российско-китайской границе, причиной которых чаще всего был вопрос о выдаче китайцам монголов и джунгаров, спасавшихся в пределах России. Цель данной статьивыяснить, какой образ Китая сложился у российской императрицы и как она отзывалась об этой стране в переписке с европейскими корреспондентами, ведь известно, что Екатерина II писала много. Для этого

Правление Екатерины II (1762-1796) совпало по времени с эпохой Просвещения в Европе и правлением императора Цяньлуна в Китае (1736-1795). Это правление было отмечено при нятием важных политических, законодательных и административных мер, достижениями в области науки, литературы и искусства, рядом военных торжеств, постоянным возрастанием народных сил и государственной славы России.

Известно, что в детстве Екатерина получила весьма ограниченное первоначальное образование. «Что делать? - Говорила она однажды.-Девица Кардель не могла выучить меня лучше. Она была старая француженка и образовала меня довольно, чтоб быть в замужестве за кем-нибудь из наших соседей» [2, C. XXIII]. Но, как Петр I и большая часть великих людей, Екатерина стремилас вначале необходимо дать характеристику личности императрицы, понять её интересы и привычки. Также нужно знать состояние российско-китайских отношений второй половины XVIII века, чтобы понять какие вопросы ей приходилось решать. И, наконец в статье даётся общая характеристика переписки Екатерины ІІ с разными высокопоставленными особами среди которых были Д'Аламбер, Дидро, Вольтер, франко-немецкий публицист Фридрих Мельхиор Гримм, швейцарский ученый и философ Иоанн Георг Циммерман, госпожа Жофрень и госпожа Бельке. Письма, получаемые ею, очень часто содержали дипломатические новости, династические проблемы, придворные сплетни, ответы её представляли из себя, большей частью, «официозныя журнальныя заметки». Привлекает внимание то, что несмотря на обширную переписку, которую вела Екатерина Велика она практически не касалась в ней вопросов Китая, исключение составили письма к Вольтеру, который как известно, восхищался Китаем и пытался больше узнать о нём от императрицы.

Ключевые слова: Китай, Екатерина II, Цяньлун, Просвещение, Вольтер, переписка.

к самосовершенствованию и вскоре восполнила недостатки в образовании, став в уровень с самыми просвещенными людьми своего века. После свадьбы она, по её словам, только и делала, что читала. «Никогда без книги и никогда без горя но всегда без развлечений», - так очерчивае Екатерина своё тогдашнее времяпровождение [7, С. 530]. Вскоре ей стали коротко известны труды современных и древних философов и политиков. Екатерина, полюбив всем сердцем вторую свою родину, изучила её язык, историю, быт её народа. Она внесла большой вклад в русскую историографию. «Наука русской истории начинается с Екатерины II» [2, C. VIII]. В её царствование были впервые напечатаны многие русские летописи, давшие возможность учёным взяться за составление российской истории. В ряду 
русских историков стоит и сама Екатерина. Ещё являясь Великой Княгиней, она ежедневно посвящала по несколько часов чтению истории, делая выписки и заметки, которые позже вошли в её «Записки касательно русской истории», появившиеся сначала в «Собеседнике», а потом вышедшие особым изданием. «Обнародование их в свете Императрица объясняет, с одной стороны, тем, что всякому народу знание своей собственной истории и географии нужнее, нежели посторонних, а с другой, что «оне сочинены для юношества в такое время, когда выходят на чу жестранных языках книги под именем истории Российской, кои скорее именовать можно сотворениями пристрастными, ибо каждый лист свидетельством служит, с какою ненавистью писан, каждое обстоятельство в превратном виде не токмо представлено, но к оным не стыдился прибавить злобные толки» [2, С. Х]. Это доказывает, Екатерина II оберегала честь России даже в области наук.

Являясь образованнейшей женщиной своего времени, императрица не могла пройти мимо идей Просвещения, среди которых была и идея о «просвещённом монархе». «Как и французские феодалы, Екатерина II и её придворные искали в образе жизни, законах, философии и истории Китая обоснование природы деспотической власти. <...> Недаром Екатерина особым указом по велела перевести Уголовное уложение Цинов, где прославлялось единоначалие правления и узаконивались привилегии маньчжурской знати» [14, C. 67]. «Екатерина читает "Essai sur les moeurs e esprit des nations, Le siècle de Louis XIV, Dictionnaire philosophique de la Chine". A пьеса "L'Orpheline de la Chine" («Китайский сирота», 1755) даже предполагалась к игре в придворном Эрмитажном театре - по аналогии с её постановкой перед Ки тайским павильоном в саду Сансуси в Потсдаме Специально по высочайшему повелению Алексей Леонтьев, один из первых европейских синологов, в 1770-х годах делает переводы с китайского языка. Причём большая часть их была осуществлена на «кошт Кабинета» [11, С. 73]. Интерес к Китаю в немалой степени подогревался общением с Вольтером, который восхищался Китаем и использовал китайский сюжет для острой философской полемики. Наиболее полно Вольтер высказался о Китае в «Опыте о нравах», «Философском словаре», «Бумагах Жана Неслье» и статье об «Изгнании иезуитов». «Вольтер замечает, что, если философ хочет говорить о событиях земного шара, он должен сначала бросить взоры на восток - «колыбель всех искусств, которой всецело обязан Запади [1, С. 317], Ека кер следует наставлениям Вольтера. Она не только изучает философию и литературу Китая, но и начинает собирать предметы китайского искусства. В Ораниенбауме появляется «Китайский дворец» в Царском селе - Китайские постройки, а в Зимнем Дворце - китайские комнаты.

Если говорить о внешней политике, прово димой Екатериной, то шаткость и переменчи вость, характерные для российской политики до её правления, уступили место решительным действиям. «Вместо дружбы со всеми державами она за 34 года своего правления перессорила Россию почти со всеми крупными государствами Западной Европы и внесла в нашу историю одно из самых кровопролитных царствований вела в Европе шесть войн и перед смертью готовилась к седмой - с революционной Франтовилась К седьмой
цией» $[7$, С. 563].

В соседнем Китае также не всё было спокой но. «С 1685 по 1792 год маньчжурские императоры вели 11 войн, продолжавшихся в общей сложности более 50 лет. С 1721 по 1795 год в Китае произошло 12 крупных восстаний, поднятых в основном национальными меньшинствами. Их подавление потребовало почти 30 лет. Внешние и внутренние военные действия зачастую протекали одновременно» [12, С. 145].

Придя к власти, Екатерина II с особым вниманием занялась урегулированием отношений с Ки таем. До середины 50-х годов XVIII века между Пекином и Петербургом сохранялись дружественные связи. Однако после завоевания Джунгарии бегства части ойратов, а затем и владетельного князя Ойратского ханства Амурсаны в русские пре делы, после перехода на русскую сторону населения отдельных монгольских княжеств, ситуация резко изменилась [12, С. 144]. Главною причиною возникавших затруднений был в основном вопрос о выдаче китайцам монголов и джунгаров спасавшихся в пределах России. Российское же правительство не могло сделаться сообщником жестоких наказаний, ожидавших перебежчиков в Китае. В результате китайское правительство не только не позволяло русским караванам пересекать границу, но даже строго запретило своим подданным поддерживать сношения с русскими $[10$, C. 28-29]
В 1762 году императрица отправила в Пекин капитана И. И. Кропотова с поручением известить императора Цяньлуна о её восшествии на престол и для урегулирования пограничных вопросов. «Руский посол был принят богдыханом, но с ним обошлись так сухо, что он не мог ничего добиться для восстановления торговли» [10, С. 30]

Отношения России с Китаем складывались непросто. Так, например, Ф. Ф. Мартенс, считает, что «с самого начала сношений России с Китаем китайцы имели к ней доверие; они всегда строго отличали русских от подданных других европейских государств, которых они называют иностранцами и даже "заморскими дьяволами"» [10, С. 2]. Но события показывали, что отношение к русским не всегда было доверительным. Причиной тому, по мнению Мартенса, было «несчастное последствие того обращения, которому подверглась Срединная империя со стороны других цивилизованных держав, и несправедливых войн веденных против нея» [10, С. 73]. Возникновению неурядиц способствовало и то, что в китайских сочинениях по географии о России упоминалось, как о государстве вассальном богдыхану $[10$, C. 7]. «Такой взгляд внушался богдыханам и отражался при приёме ими русских посланцев. Долгое время богдыханы искренне видели в них лишь по сланных от подвластнаго себе народа и требовали унизительных для русскаго достоинства поклонения и дани. Те из русских людей, присланных для установления торговых сношений с Китаем или по пограничным делам, которые не соглашались на унижения, не достигали и цели своей миссии» [8, С. 76]. Всё это не могло не отразиться на российско-китайской переписке. «Российская сторона, договорным образом подтверждая готовность переписываться с Лифаньюанем (Палатой по делам вассальных (!) территорий), как бы признавала себя "вассалом" Цинской империи. Однако, с другой стороны, с этим "назначением" отныне "снимались многие противоречия, возникавшие при переписке царей, следовательно, процесс достижения Россией своих целей облегчался"» $[9$, С. 107]

С 1763 года отношения между Россией и Китаем приняли ешё худший оборот, в 1764 году всякая официальная переписка с китайским правительством была прекращена, так как императрица Екатерина II не могла, не роняя своего достоинства, отвечать на дерзкие ноты «Лифаньюаня» $[10$, С. 30]. Обострившиеся отношения с китай цами заставили Екатерину в августе 1764 года составить в виду принятого китайцами «угрожающаго» положения чрезвычайную конференцию из князя Голицына, графов Панина, Чернышева, Миниха, Олсуфьева, Неплюева и Вильбоа, одним из намерений которой было отправить военную экспедицию к Амуру [15, С. 60]. В том же 1764 году она учредила комитет из компетентных лиц для изучения условий торговли с Китаем, по результатам работы которого было принято решение отменить казённую торговлю с Китаем и отдать её в руки русских купцов, а всё админи стративное управление Сибири преобразовать с целью улучшения отношений с Небесной империей [10, С. 29].

С 1762 по 1768 год торг беспрестанно прекращался и возобновлялся до тех пор, пок в 1768 году снова был послан капитан Кропотов в Кяхту для разрешения споров по пограничным и торговым делам. «После долгих прений, уполномоченные подписали, 18-го октября 1768 года, отдельный акт или дополнение к трактату 1727 года [10, С. 30]. С 1768 года после семи лет раздоров настали семь мирных лет - самый продолжительный мир начиная с 1719 года [15, С. 62]. Следующий разрыв отношений с китайцами произошёл в 1778 году (продолжался до 2 апреля 1780 года) по поводу некоторых Олотов, русских подданных разграбивших русских купцов и бежавших в Ки тай [15, С. 63]. В 1785 году произошёл новый раз рыв, продолжавшийся до 24 апреля 1792 года. На границе было поймано несколько разбойников русского подданства во главе с Уладзаем (Улагаем). Китайцы требовали их казни на месте преступления, а иркутский губернатор только сослал их. «Вследствие этого трибунал в 1785 году в листе своём жалуется, что губернатор своевольно только выбив палками Улагая и прочих, прежде шатавшихся, сослал их в отдалённую ссылку» $[15$ C. 63]

На фоне всех этих событий интересно было знать, как отзывалась российская императрица о Китае в своей переписке с иностранными корреспондентами, ведь, как известно, писала он много, и, как однажды заметила своему секретарю Грибовскому, «не пописавши нельзя и одного дня прожить» [2, C. XIII]. Причиной такой литературной активности было не только свойство её характера, но и влияние духа времени, когда было принято подражание великим умам того века. Отсюда берёт начало та обширная переписка, которую 
императрица вела сперва с Д'Аламбером, Дидро и Вольтером, потом с полунемцем-полуфранцузом Гриммом, затем с ганноверским учёным Циммерманом, с госпожой Жофрень (M-me Geoffrin) жившей в Париже и имевшей литературный салон, считавшийся литературным центром и верховным эстетическим судилищем, госпожой Бельке (M-me Bielke), которая в годы детства Екатерины была близка к её матери и жила в Гамбурге. «Эти сношения имели многообразную цель: с одной стороны, Екатерина желала таким способом быть постоянно в известиях обо всем, что происходило на западе и что о ней говорили; с другой, зная обширныя связи этих лиц, а также их авторитет и влияние на общественное мнение она желала своими письмами к ним распространять за границею верныя, или по крайней мере согласныя с ея видами, сведения о русских делах, опровергать клеветы и лживые толки, которые безпрестанно были распускаемы врагами России» [2, С. XIV]

«Письма, получаемые ею, очень часто содержали политическия сообщения, ответы её представляли из себя, большею частью официозныя журнальныя заметки: были здесь и бюллетени о походах, и воинствующие статьи, и, даже, «настоящие манифесты, как в письме от 21 января 1791 года, писанном к Циммерману, но предназначенном для берлинскаго двора, который надо было успокоить, давши ему в то же время совет не вмешиваться в турецкия дела. Многия из записок к Вольтеру имели целью поколебать положение герцога Шуазеля. Сама Екатерина однажды призналась в том Храповицкому» [5, С. 385-386].

При ознакомлении с её перепиской с разными особами, составившей пять томов, изданных Императорским русским историческим обществом, бросается в глаза то, как много она пишет о европейских делах и практически ничего об отношениях с Китаем, что, в общем, следует расценивать как положительное явление. Её корреспондентами, в разговоре с которыми она касается Китая, был Вольтер, а затем принц Шарль де Линь. Знакомство с произведениями Вольтера началось вскоре после её прибытия в Россию, когда она, по совету прусского посланника Мардефельда, отказалась от праздного препровождения времени и принялась за чтение $[2, \mathrm{C}$ XVI]. «С 1746 года, с того времени, как Я разполагаю Своим временем, Я чувствую ваше вели кое одолжение. Прежде сей эпохи Я не читал иных книг, кроме романов; но нечаянно попались Мне в руки ваши сочинения. С того времени они составляют Мое всегдашнее чтение и Я не искала иных книг как только таких котои А не искала иных кни, как толко таких котомного полезнаго» $[13$, С. 4-5], — пишет она в первом письме к Вольтеру.

В переписке Екатерины II с Вольтером, которая Алилась с 1763 по 1777 год - до смерти Вольтера, затрагивалось огромное количество вопросов о русской внутренней и внешней политике. Об этой переписке у польского историка К. Ф. Валишевского (1849-1935) есть интересные строки. «Она мечтала построить в Царском Фернейский дворец, воспроизведя вполне внешний и внутренний вид знаменитаго жилища, - комнату, где мыслил и писал философ, даже пейзаж, н котором покоился его взор. В то же время она ни за что не соглашалась опубликовать свою переписку с ним: ея письма были слишком дурно написаны, его - слишком лестны для нея и непочтительны для других властителей. И так как эта корреспонденция многими не одобрялась а слишком подозрительное высшее духовенство видело в ней почти что скандал, она начала просто отрицать её. Не могла же она запретить Вольтеру писать ей - столько людей ей писали! Но она не отвечала ему, она отклонила все попытки его вовлечь её в переписку, которая была бы недостойна императрицы всея Руси» [5, С. 213]

«В своих откровенных беседах с Гриммом "их тон очень заурядным"» [5, С. 391]. Это отнюдь не характеризует Екатерину как не мудрого правителя. Как уже было сказано, Екатерина была очень начитанна и во всём оберегала интересы России. «В приёме ею иностранных послов, в сношениях с кем бы то ни было, каждое слово, каждый шаг ея показывали необыкновенный такт и искусство безошибочно производит желанное впечатление. Екатерина была такой же тонкий дипломат, как и искусный администратор 2 С. XXIV]. Екатерина старалась следовать современной моде. «Мода же была относиться ко всему небрежно, иронически, вносить насмешку даже в обсуждение самых серьезных вопросов. Ко всему этому Вольтер приучил свою ученицу она в восторге от такого направления и применяет его и вкривь, и вкось, как женщина капри зная, смелая, мало обращающая внимание н правила и приличия» [5, С. 391]
Отношения между честолюбивой, политически могущественной женщиной и высокоодарённым, универсально образованным философом одним из крупнейших авторитетов французского Просвещения, были взаимовыгодными. Екатерина осознавала, что письма к Вольтеру станут известны его друзьям, и относилась к ним, как посланиям к интеллигенции Европы. «Для Вольтера, что могло быть ещё более лестным, чем иметь ещё одного королевского ученика в лице правящего монарха? Он обращался к ней как "Cемирамида Севера", "Святая Екатерина" и "Наша леди Санкт-Петербурга". В ответ она осыпала его соболиными мехами и табакерками с драгоценностями и посылала бриллианты Мадам Дэнис. Но это были отношения, которые процветали на расстоянии; несмотря на интимность их корреспонденции, Императрица и почтенный старец ни разу не встретились» [16, С. 335-336].

Как отмечает Валишевский, письма императрицы можно разделить на три категории: письма, писанные ею, сочинённые ею и напи санные по её заказу. Первые - наиболее редки [5, С. 386]. Письма к Вольтеру, на его взгляд почти все были написаны по заказу и являлись своего рода литературными произведениями «Пишу я собственноручно только к таким людям, которые, как я полагаю, любят меня, и которыми я дорожу; мне невозможно гоняться за остроумием, отборным изложением, - писала она герцогу де-Линю, - следовательно, я вовсе не для того пишу, чтобы это было напечатано, и ничто мне не кажется таким пошлым, как то что я написала, когда оно мне попадается в печати» [4, С. 96]. Она собственноручно списывала письма к фернейскому патриарху, сохраняя свойственную ей манеру писать: «известную фамильярность, игривое добродушие и искренность, даже оригинальность мысли и выражения», искусно обработанные поставщиками французской или русской прозы - Шуваловым, Козицким или Храповицким, по очереди служившими секретарями императрице [5, С. 387].

Как известно, Вольтер в своём сочинени «Опыты о нравах» первоначально, до прибав ления вводной части, начинал своё изложение всемирной истории с Востока - Китая, «где впервые зародилась цивилизация, в то время как Запад пребывал в полном варварстве» [6, С. 173-174]. В противоположность древнему Израилю и государствам нового времени, у Вольтера — это страна обретённой мудрости, справедливости и внутреннего мира. «Хотя китайцы не преуспели в науках но это первый в мире народ по морали и культурности (police). Это объясняется, по мнению Вольтера, тем, что во главе государства стоит мудрец - император, окруженный философами мандаринами. Они исповедуют конфуцианство, которое представляет чисто философскую рели кию - деизм. Народная масса, правда, коснеет в грубых религиозных предрассудках, но император и мандарины мудро используют удобные случаи, чтобы подрывать в народе грубые верования и культы. Отправляясь от сентиментальных, идеализированных описаний путешественников и миссионеров, Вольтер создал из китайской истории морализующую басню и поучение европейцам» [6, С. 174]. Естественно предположить, что, переписываясь с Екатериной, Вольтер не мог не осведомляться о соседе России - Китае, к которому он испытывал такой интерес.

Вначале философ пытается завести разговор относительно литературных талантов китайских императоров. Так, в письме от 26 мая 1767 года Вольтер пишет: «Сосед Ваш, Китайский Император, Камги, спрашивал одного Миссионера, можно ли на Европейских языках писать стихи? Он в этом сомневался» [13, С. 25]. Но Екатери на решила оставить без ответа это замечание. Через три года Вольтер в письме от 20 ноября 1770 года снова пытается затронуть тему Китая: «Вы имеете двух соседей, которые сочиняют стихи, а именно Король Прусской и Император Ки тайской; кои Фридрих уже сочинил Вам в похвалу, я имею и теперь ожидаю их от Киен-Лонга» [13, С. 133]. И снова не последовало ответа на эти строки. В следующем письме от 26 ноября Вольтер опять упоминает богдыхана: «Да здравствует Китайской Император! Он сочиняет стихи и с це лым светом живет в мире!» [13, С. 134] И снова молчание в ответ. В следующем письме от 22 декабря 1770 года Вольтер уже пишет с нетерпени ем: «Всемилостивейшая Государыня! Страсть мо становится несколько нещастною. Я не имею известия ни о Вашем Императорском Величестве ни о враге моем Мустафе. Все, что я могу еще сделать, состоит в том, чтоб сообщить Вам скуч ную мою переписку с Китайским Государем, Вашим соседом» [13, С. 140].

Как упоминалось выше, годы с 1762-го по 1770-й были наполнены решением многочисленных неурядиц, возникавших на российско-китай- 
ской границе, о которых Екатерина предпочитала не распространяться. И, наконец, в письме от 12/23 декабря 1770 года она заговорила о Китае: «Ах, Государь Мой! Вы так много расхвали ли Китай, что Я уже не смею не одобрить стихов, сочиненных Государем той страны. Однако же по делам, кои Я имею с сим Правительством, могла бы Я представить такия доказательства, которыя весьма уменьшили бы всеми принятое доброе мнение о их просвещенности, и заставили бы об них думать, как о грубых невежах; но на что обижать ближняго? Я, наложив на себя молчание, дивлюсь без всякаго противоречия присылаемым от находящихся там веропроповедников повествованиям. Сверх сего и то надобно сказать, что я имею дело с правлением Татар, овладевших Китаем, а не с природными Китайцами» [13, С. 143].

Затем, в следующем своём письме от 12/23 января 1771 года Екатерина продолжает: «Мне кажется, что вы можете быть довольны 1770 годом, и что не имеете еще причины соседом Моим, Ки тайским Государем, величаться, у которого Я, не смотря на его стихи и возродившуюся вашу к нему любовь (прошу не сердиться), не нахожу почти общаго смысла. Вы скажите, что одна ревность заставляет Меня там говорить; отнюдь нет; Я не поменяюсь Римским своим носом на плоское его лицо; не завидую также и дарованию его сочинять дурные стихи; Я люблю лишь одни ваши читать. Эпистола, писанная к Моему сопернику, прекрасна. Тотчас по получении показала ее Прусскому Принцу Генриху, и ему она равное принесла удовольствие. Естьли же судьбе угодно, чтоб Я, в разсуждении вас, имела совместни ка, то молю Пресвятую Богородицу Марию, чтоб это другой кто был, а не Китайской Государь; ибо Я на него сердита» [13, С. 148].

Затем, видно, в отношениях с Китаем наступает оттепель, так как императрица через два месяца пишет более мягко (письмо от 3/14 марта 1771 года): «С того времени, как сосед Мой, Ки тайской Государь, уничтожил некоторыя несправедливыя притеснения, то подданные его вступили с Моими в торговлю. В первые четыре месяца как сей торг открылся, променяли они товаров на три милиона рублей. Собственныя фабрики Моего соседа заняты деланием для меня обоев а сам он просит Меня доставить ему овец и хлеба» $[13$, C. 156]

В следующем письме (письмо от 5/15 марта 1771 года) Екатерина даёт более развёрнутую ха- рактеристику отношений с Китаем: «Вы желаете чтобы Я объявила вам нечто о невежестве и грубости Китайцев, о которых Мною упомянуто было в одном из моих писем. Мы соседи, это вам вестно границы наши с обеих сторон населяют Татары и идолопоклонники, скотоводством питающиеся. Сии народы чрезмерно склонны к грабе жу. Они похищают друг у друга (часто из одного мщения) стада и даже людей. Произшедшия от того ссоры прекращены посланными на грани цы Коммисарами. Господа Китайцы такие великие ябедники, что с ними самыя малости столько же трудно окончить, как море выпить. Неоднократно случалось, что они, будучи во всем уже удовлетворены, требовали костей после умерших не для того, чтобы оным какую честь воздать, но для того, чтоб над ними наругаться. Подобныя скаредности служили им в продолжении десяти лет предлогом к пресечению торговли; Я говорю предлогом по тому, что истинная причина была та, что его Китайское Величество торг с Россиею отдал одному из своих Министров в Монополию. Китайцы и Россияне были тем равно недовольны; а как очень трудно прервать всякой меновной торг, то оба народа производили мену своим товарам в тех местах, где не было учреждено таможенных застав, предпочитая свои нужды опасностям. А когда от нас им сообщено было подробное сведение о состоянии взаимного сношения, то в ответ получили мы от них превеликия кучи бумаг, написанных так беспорядочно, что вместо смыслу и вежливости, прочита их с начала до конца, видны были одне невеже ства и грубости. От нас им на это сказано было, что у нас такой слог совсем не годится, потому что он в Европе и Азии почитается оскорбительным. Я угадываю ваше возражение. Вы скажите что Татары, Китайским Государством овладевшие гораздо хуже древних Китайцев; согласна! Одна кож это останется неоспоримым, что победители не научились вежливости у побежденных, а сии напоследок принуждены будут покориться обычаям господствующим» [13, С. 160].

Это то немногое, что Императрица позволил себе сказать о Китае. Кроме обсуждения стихо императора Цяньлуна и торговых дел с Китаем ещё одной темой переписки становится возМожность посредством русских купцов сбывать в Китай часы, производимые фабрикой Вольтера. «Чтобы помочь людям в его деревне, он построил фабрику по производству часов и затем склонял всех своих друзей в Европе купить их продукцию; <...> К 1777 году эта когда-то маленькая, обнищалая деревня из 49 человек превратилась в процветающий городок из 1200 человек [16, C. 334]

Екатерина II не стала исключением - Вольтер обратился к ней с пространной речью, очень напоминавшей предложение разместить у него заказ. «Мне кажется, естьли бы Ваши Нипхские Татаро-Китайцы были догадливы, тоб могли они накупить недорогих часов и продавать их по своему Государству с великим барышем. Женевць имеют в Кантоне Контору, и получают там знатную прибыль. Не можно ли учредить таковой же и на Вашей границе? Колония моя наделала бы часов серебряных, ценою от 12 до 15, а золотых от 50 до 40 рублей. При том обязалась бь она в каждой год выставлять оных, ежели потребуется, на 200,000 рублей. Но мне кажется, что, по недоверчивости и подозрительности Китайцев, едва ли можно вступать с ними в большой торг, требующий сговорчивости и откровенности» $[13$, С. 167]

Императрица не ответила отказом, а приобрела часов на три-четыре тысячи рублей. Но Вольтер вскоре выслал ей вторую партию часов, поспешив извиниться: «Это случилось от слишком большого рвения "колонистов",- это не его, а их вина. Впрочем, счет составляет всего 39,238 француз ских ливров, это на половину дешевле, чем в Лондоне, Париже и даже Женеве. При уплате даются все льготы" - "Хорошо, отвечала Семирамида но это в последний раз". Она послала 39,238 ливров, вместе с бюллетенем о последних подвигах русских войск, о которых должен оповестить Европу человек, котораго наиболее читают во всем свете» [5, С. 202].

Далее в письме от 24 мая/4 июня 1771 года Екатерина выражает своё согласие на предложение о сбыте часов. «Я думаю, что была бы возможность доставлять их изделия в Китай; но для этого был бы нужен какой-нибудь образованный купец, который знал бы обычаи торговли с Кяхтой - пограничное с Россией место, где эта торговля производится. <... По моему повелению пересматривается таможенный тариф по торговле с Китаем с целью облегчить его, чтобы содействовать ввозу и вывозу. Цены, которыя вы назначаете, так умеренны, что изделия вашего производства могут иметь большой сбыт» [2, C. 103].
Вольтер, видимо, был воодушевлен этими строками, поскольку в одном из писем снова пытается предложить Екатерине часы, но уже настенные. Н что Екатерина в письме от 3/14 декабря 1771 года предложила обратиться «к какой-нибудь здешней конторе, где есть женевцы, которые легко найдут средство доставлять часы на китайскую границу» [2, С. 199].

Последнее письмо к Вольтеру было написано 4 декабря/23 ноября 1777 года, 30 мая 1778 года философа не стало. За 14 лет переписки Вольтер и Екатерина так и не встретились.

Больше Екатерина в своих письмах не касалас китайских дел, лишь иногда в переписке с принцем де-Линем, которая началась в 1781 году, она вскользь касалась китайского императора. Так в письме к принцу де Линю о воспоминании оставленном им о себе в России (11 июля 1782 г.), она писала: «Ни мой дорогой друг, Византийский Император, ни добрый мой сосед, Император Китайский не в силах помешать мне читать ваши письма, безконечно более приятныя, чем их письма, не смотря на их высокий ранг в альманахах [3, С. 210]. Или, как в письме о соседних с Россией государствах (16 ноября 1790 г.) она сообщала: «В пекинской газете сказано, что мой китайский сосед с маленькими глазками, о котором вы так почетно отзываетесь, соблюдает с истинно при мерной точностию все безчисленные обряды которым он подчинен» [4, С. 125]. Это то немногое что позво трица в переписке с принцем.

Подытоживая вышесказанное, можно сказать, что на взгляды Екатерины относительно Кита большое влияние оказал Вольтер, с произведениями которого она была хорошо знакома и переписку с которым вела в течение четырнадцати лет. Именно при Екатерине в русской периодике появляется большое количество переводных материалов на тему философии, государственного устройства и обычаев Китая. Но, читая бумаги, исходящие от китайского правительства, он осознавала, что всё то, чем восхищался Вольтер относилось скорее к древней китайской культу ре, носителем которой являлась национальность хань. Ей же приходилось иметь дело с захватив шими власть маньчжурами, пришедшими с северо-востока, обычаи и традиции которых несколько отличались. Обстановка на российско-китайской границе была неспокойной, торговые отношения с Китаем в царствование императрицы Екатери- 
ны II (1762-1796) прекращались три раза, а именно с 1762 года на шесть лет, с 1778 года на два, с 1785 года на семь лет. Было трудно вести переписку с китайским двором. И тем не менее императрица предпочитала не распространяться насчёт отношений с Китаем в письмах к своим многочисленным европейским корреспондентам которые она писала практически каждый день. Исключение составили письма к Вольтеру, на за-

БИБЛИОГРАФИЯ

1. Алексеев М.П. Пушкин и мировая литература.Ленинград: «Наука», 1987.

2. Бумаги императрицы Екатерины II, хранящиеся в государственном архиве Министерства иностранных дел.-Т. 3. (1762-1774).-СПб.: Типография Импе раторской академии наук, 1874

3. Бумаги императрицы Екатерины II, хранящиеся в государственном архиве Министерства иностранных дел.-Т. 4 (1774-1788); Сборник императорского русского исторического общества.- Т. 27.-СПб: Типография Императорской академии наук, 1880.

4. Бумаги императрицы Екатерины II, хранящиеся в государственном архиве Министерства иностранных дел.-Т. 5 (1789-1796); Сборник императорского русского исторического общества.-Т. 42.- СПб. Типография Императорской академии наук, 1885.

5. Валишевский К.Ф. Вокруг трона: Екатерина II.-M. Сфинкс, 1911.

6. Вольтер: Статьи и материалы / Под ред. акад. В. П. Волгина; Акад. наук СССР.-Москва; Ленинград: 2-я тип. Издательства Академии наук СССР, 1948.

7. Ключевский В.О. Русская история. Полный курс лекций в 2-х книгах.-Книга 2/Послесловие, комментарии А. Ф. Смирнова.—М.: ОЛМА-ПРЕСС, 2003.

8. Куропаткин А.Н. Русско-китайский вопрос.-СПб Тип. Товарищества А.С. Суворова «Новое Время», 1913.

9. Лапин П.А. Российско-китайская межгосударственная переписка как вид внешнеполитической деятельности: китайский аспект (первая половина XVIIвторая половина XIX в.) // Россия и Китай: проблемы стратегического взаимодействия: сборник Восточного центра. - 2012. - № 12.-С. 106-114.

10. Мартенс Ф.Ф. Россия и Китай. - СПб.: Тип. И. Габермана, 1881

11. Меньшикова М. Здесь «все дышало амброзией Азии» // Воображаемый Восток: Китай «по-русски». XVIII - начало XX века / Сост. О. А. Соснина.- М. Кучково поле, 2016. - С. 66-73.

2. Непомнин О.Е. История Китая: Эпоха Цин. XVIII начало XX века.-М.: Восточная литература, 2005

13. Переписка российской императрицы Екатерины и господина Вольтера, продолжавшаяся с 1763 по 1778 год / Перевел с французского Иван Фабиян; С портретом императрицы и Вольтера.-М.: В вольной типографии Гария и Компании, 1803.

14. Скачков П.Е. Очерки истории русского китаеведения.- М.: Издательство «Наука», Главная редакция восточной литературы, 1977.

15. Трусевич Х. Посольские и торговые сношения России с Китаем (до XIX века).- М.: Типография Г. Малинского, 1882.

16. Robert K. Massie. Catherine the Grate: Portrait of a Woman. - New York: Random House Trade Paperbacks, 2012

Tatiana V. Portnova

Doctor of Art History, Professor.

Kosygin Russian State University.

e-mail: infotatiana-p@mail.ru

Moscow, Russia

ORCID ID: 0000-0002-4221-3923

DOI: 10.36340/2071-6818-2021-17-4-79-90

\section{ARCHITECTURAL SPACE IN DANCE AS AN ARTISTIC AND FIGURATIVE SYSTEM}

Summary: The study examines the expressive means of dance and architecture, establishes common and specific areas in the nature of their artistic language, identifies the extent of interaction between architectural principles with dance dramaturgy and choreographic composition and analyzes examples of interpretation of dance production solutions in the architectural space. Through a simultaneous review, the author examines the expressive means of dance and architecture, establishing the common and the specific in the expressive and pictorial nature of their artistic language. The focus is on identifying the degree of influence of architectural principles on the dance drama, choreographic composition, and the reverse impact. The analysis provides examples of the interpretation of dance staging solutions in the architectural space, including innovative modern practices of the 20th-21st centuries. The artistic and imaginative metamorphoses of staged choreographic solutions occurring in different kinds of architectural spaces are concurring in different kinds of architectural spaces are con-
sidered. Starting with the perspectivism of the scenery on the stage and the light architecture of the 18th cenon the stage and the light architecture of the 18th century, the author moves on to the monumental construction of the large stage performance of the 19th century and concludes with the choreographic experiments of the early 20th century. The article points out that modare tween choreography and architecture: dances ar

Dance in architectural space is a complex, multidimensional problem lying at the intersection of art, philosophy, and engineering technology. This study examines this topic as an artistic and aesthetic category in the context of the expressive means of choreographic art, which finds its creative understanding and diversity of forms of artistic representation of space through dance.

While the modern scientific literature sufficiently covers the matters of the morphology of dance and its linguistic nature, the issues of architectur- directly in the interiors of buildings, bypassing the traditional stage platform. The implied idea of human movement in space, encompassing the viewer, appears here because of successively changing impressions. Finally, the author explores the directorial approach, where the choreography itself masters and constructs the architecture, helping the viewer to perceive themselves as if within its own spatial structure. This peculiar artistic and visual synthesis appears in the dynamics of genre and style of the author's stage context. The study of the specifics of ballet as a dramatic phenomenon seems to be a fundamental research task, because, more than any other theatrics genre, it is the ballet that provided extremely diversified artistic samples of space and stage creativity in the heritage of the 20th century, and probably, will continue to do so in the 21st. The question of dance interpretation in the architectural space is a significant independent subject of research in connection with the structure and evolution of the artistic image in contemporary choreographic art Against the background of postmodernist modern style trends as global creative principle of post-culture, this topic includes breade principle of post-culture, this topic inthe understanding of the artistic process in contempothe understanding

Keywords: architectural space, dance functioning, choand figurative system, synthesis of architecture and dance

al space as a necessary substance existing in the choreographic art rarely become an object of re searchers' attention. Stage space, from its origins to modern times, shaped by the methods of scenography, was the subject of Viktor Berezkin's analysis. [1] Future choreographers study space as an expressive means in dance composition during training courses, which allows them to form a conscious attitude and motivation in working with the scenography whole. Jean-Georges Noverre considered the stage as a geometrical system in the contex 


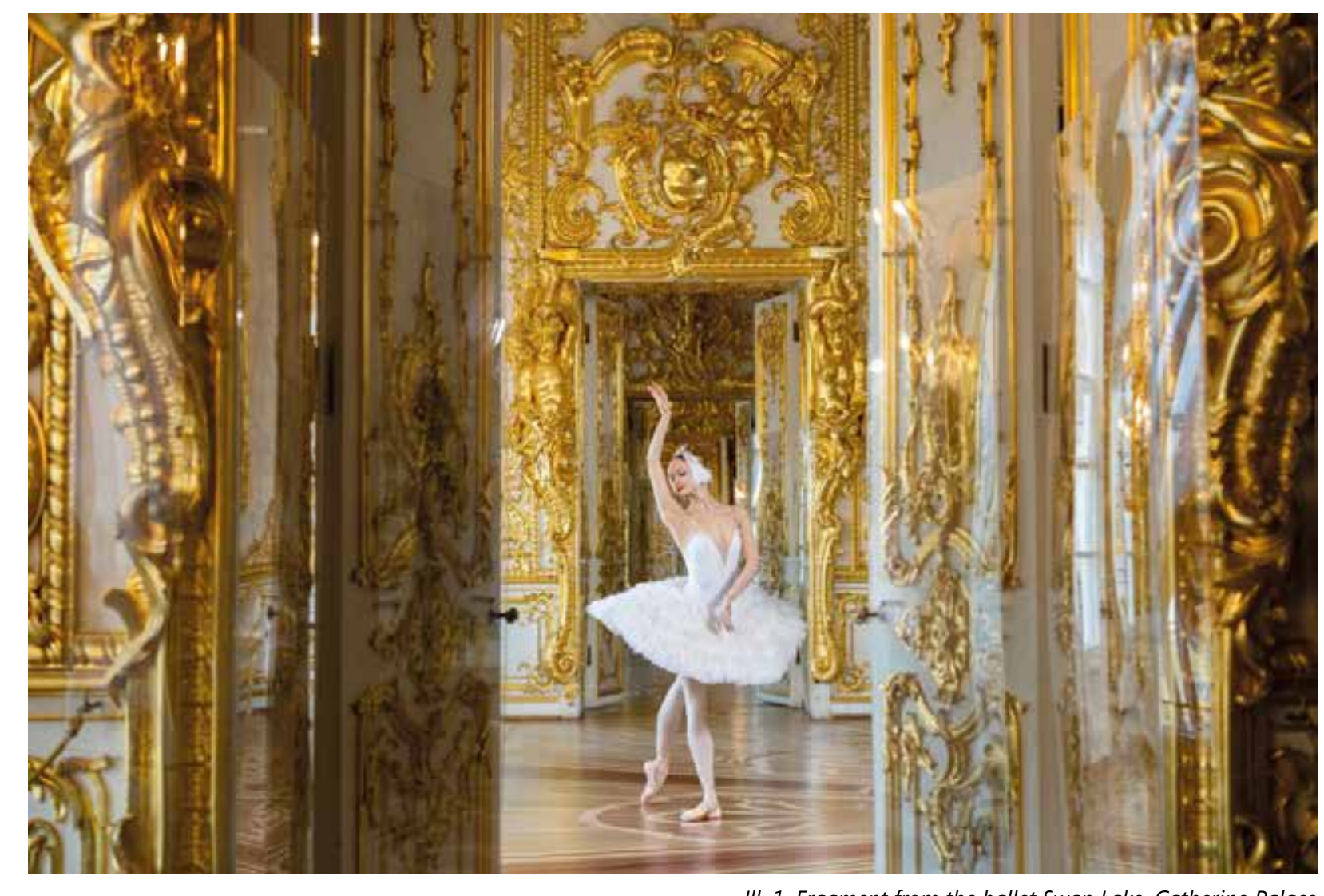

III. 1. Fragment from the ballet Swan Lake. Catherine Palace

of understanding the compositional activity of the dancer and the organization of dance elements to create a coherent harmony of the choreographic composition. [2;3]

The problem posed in this article is somewhat touched upon in the ballet literature in connection with the reflections of dance theorists, as well as in the context of the work of several choreographers such as Marius Petipa, Mikhail Fokin, Kasyan Goleizovsky, Leonid Yakobson, Yury Grigorovich, Boris Eifman, Martha Graham, Rudolph von Laban, Merce Cunningham, Maurice Béjart, and Yevgeni Panfilov. They reflected on a conceptual, artistic, and spatial vision of dance nature. $[4 ; 5 ; 6]$ According to them, space is a peculiar object of choreographic content, necessary to be reinterpreted each time. Yulia Churko described the techniques of contemporary choreography functioning in the context of the aesthetics of performativity as a way of forming new connections between elements of artistic and spatial composition, taking the viewer's perception into account. [7]

A significant group of studies considers the theatrical space as a philosophical category. [8;9;10] For instance, Galina Lebedeva, operating with the concepts of ballet, semantics, and architectonics from the position of the system approach and synerget- ic paradigm, analyzes the spatial and temporal parameters of the ballet performance and the specifics of interaction between its components. [11] Olga Gerdt, in her study Territory of possibilities. In motion, proposes to consider the changeable nature of the performer's plasticity, which allows different spatial mean cluded in the spatial environment, it can reveal the multiplicity of ways of understanding the theatrical image and provide the potential for the emergence of new relationships to its content. [12]

Now you can find reflections on the integrative principle of modern architecture: "The multi-element forms of creativity, primarily theater, film, television, and modern choreography, correlate with current architectural trends of 'directing' and 'spectacle'". Despite the conventionality of this relationship, some phenomena and approaches in the sphere of the performing arts can be described as actual principles of architecture: scenarity, emphasized visual expressiveness, the construction of volumes and spaces as 'mise en scène' of the performance, the architectural 'set' and the change of 'frames' spatial impressions in motion. [13] Indeed, the art of architecture, as well as the art of dance, has long followed the law of artistic integration, so architects and choreographers employ artistic synthesis as kind of complex integrative method of professional activity. [14; 15;16]

However, despite the mentioned sources, art history still lacks a full-fledged analytical approach from the perspective of the architectural component of a ballet piece.

The methodological concept of the study relies on the principles of holistic research of the dance in the architectural space: from the philosophical aesthetic, artistic, and imaginative issues of its consideration to the linguistic and stylistic ones. Exploring some historical aspects of the synthesis of dance and architecture, we evaluate the events and phenomena of theatrical life from a modern perspective, given that the chosen topic, the collaboration of the playwright, director, and architect, has direct relevance to the creative practice of modern days that is relevant not only for Russian but for the multinational theater as well.

A solid architectonic structure should be at the heart of any choreographic performance. Konstantin Stanislavsky held the art of mise en scène in high regard, demanding a precise scheme for an actor's movements in space. He called the actor the engineer, the architect of the role. "No choreographic image can exist without a spatial structure without a well-thought-out constructive principle, which determines the pulse of the entire production. The corps-de-ballet masses, formed in various ways during the performance, also shape a spaarchitectonics of a ballet performance consists of two verbal components. One goes into the image the artistic design, and the organization of space the other remains in the dance." [17: c. 170]. Oskar Remez noted: "Directing is a construction art". [18: p.103] Finding a spatial principle for a performance is a fascinating task for a choreographer but never an easy one.

The sixteenth-century stage in Italy, a box in the setting of court architectural performances and primitive fairgrounds on which vagarious actors entertained the crowds gathered in the square, created two systems of theatrical spaces, which can be identified as closed and open spaces. The closed space exists on the stage, inside the interior of the theater building. The open space spread to the natura and architectural environment. The French choreographer Maurice Béjart characterized architecture as an art that seriously influenced ballet: "I worked a lot with architects, maybe not very famous ones.
They created a new stage space for me, an important element of the performance. My best performances go on the Italian stage with the canvas rising On. Every time I arrange my stages differently." [19: p.7-8]

Since the 16th century, the stage has been developing the techniques of perspectivism. It can deepen the architectonics of the stage action vis ually. Even conventionally abstract sets with the image of architectural structures can emphasize and strengthen the spatial and visual development of the performance, the mutual conditionality of the dancers and the environment. The juxtaposition of linear perspective in two-dimensional Renaissance decoration with the space of actual architecture unwittingly leads to an illusory convergence of the ontological systems of these types of creativity.

You can observe a different concept of space based on the relationship between light architecture and dance. It is not an invention of the modern era by any means. In a latent form, it had already been incorporated into the figurative structure of the eighteenth-century architecture of the royal pleasure residences of Moscow and Saint Petersburg: Tsaritsyno, Arkhangelskoye, Kuskovo, Ostankino, and Peterhof where theatricalization was particularly important. The very architecture of these ensembles with their regular planning principles was designed for the atrical spatial play, the change of processions, and acquired a theatrical character. The landscape architecture of the time was considered an art form, equal to others. The extravaganza created by the decorative nature of colored lanterns gave rise to an image of illusory light architecture, becoming a generator of unfolded space, although it has not yet achieved a geometric logic of light beams similar to modern stage apparatus in terms of its organization. At the same time, here we should consider the conventionality of the stylistic characteristic of the architectural ensembles themselves and the lack of clear boundaries between them. Sometimes eners, and theatrical event izers combined features of several different styles and worked at their junction, relying on decorative and emotional principles rather than functional and technical ones, thus complementing the structura plastic with ornamental one.

Marius Petipa and Lev Ivanov's monumental construction of a large stage performance, Kasyan Goleizovsky's constructivist experiments, the movement of dance forms, their transformation and juxtaposi- 
tion by George Balanchine: all these are examples of the use of different spatial systems. The figures of the performers themselves create the architecture, orienting the viewer to their own spatial structure. The dancers of Petipa and Ivanov gravitate towards symmetry of forms and synchronous ensemble while preserving the lively spontaneity of each image. The corps de ballet groups of Swans, Willis, and Shadows in Swan Lake, Giselle, and La Bayadère, almost genetically created that astonishing dance geometry, without which the choreography of these ballets is unthinkable, by lining up in parallel, diagonal, and other rows on the stage floor. Kasyan Goleizovsky, the experimental choreographer of the early twentieth century, often reduced acting groups to elementary schematic simplicity. The direction acquired through sophistication was pointed upwards: it is vertical, not horizontal (like in the case of Ivanov and Petipa). He used stairs, bridges, and other architectural elements in his design (so there was an interaction between the architectonic structure of the design and the tectonics of the figures of the performers in space). It was the most extreme manifestation of choreographic tectonic rationalism (1920), whose naked constructiveness was so consonant with the architectural pursuit of the time. In this form, the abstract prop buildings find their place as the subject filling of the stage environment and interact with the rationalist architecture in unison, as elements connected to it, bringing their constructional and volumetric emphasis to the choreography.

"One example of the bold, original method of interaction between choreography and architecture can be the staging of dances directly in the interiors of buildings, bypassing the traditional stage platform. The idea of a person moving in space from hall to hall, the excitement that embraces the viewer because of the change of specific, consistently changing impressions, was clearly revealed in the production of choreographic miniatures by Leonid Yakobson in the halls of the Museum of Ceramics at the Kuskovo Estate. The basis of the composition was an open space, a suite of halls without any clearly delineated borders and symmetrical axes, but still subjected to a certain rhythmic regularity. Thi space is neither topographical nor mathematical but rather alive and active. The dance movement leads from one hall to another. There is a vigorous unfolding of the action, an abrupt alternation of scenes, a quick change of backgrounds, a play on details, foreshortening glance. As the gaze moves, numerous architectural elements and details (doors, openings, windows, columns, chandeliers, decorations, etc.) enter the field of view, participating in the crespaces, forms, textures, and directions give rise to the multiplicity of impressions that constantly attracts the viewer instead of boring him with monotony." [20: p.7] The principle of unfolding spaces builds on its successive change, acquiring a specia structural significance and developed semantics in the form of cinematic demonstration of choreographic numbers.

Noteworthy, the principle of combining different visual positions in the image was discovered long before the advent of cinematography. The American architect Philip Johnson proposed the concept of 'professional' architecture, arguing that the design of space and molding of volumes only supplement the main thing: the organization of processes. According to him, beauty lies in the way we move through space.

Architectural theorist Andrey Ikonnikov wrote in response: "This point of view may seem paradoxical but it emphasizes one of the Greek specificities of architecture very convincingly." [21: p.8] In this example, one can feel and comprehend, with particular fullness, the organicity of artistic thinking and the rare ability of choreographer Leonid Yakobson to harmoniously combine different types of art into a single matter of a coherent ensemble.

"In the second non-traditional theatrical system of open space, not only choreography masters architecture in coexistence, it builds architecture itsel as we have stated, helping the audience to feel as if inside its own spatial structure Maurice Béjart who worked with the French and Russian troupes in Saint Petersburg, made such an attempt of plastic and architectural conceptualizing. Against the background of the Neva embankments, Mikhailovsky Castle, Peter and Paul Fortress, Kazan Cathedral, and Nevsky bridges, unforgettable choreographic images were born, as if filled with the atmosphere of a modern city." [22: p.174]. The panoramic background of the northern city, designed for the unrestrained contemplation of nature, seemed to signify the disappearance of the architectural scenery that had existed in theatrical painting before. The water space of the Neva, with its horizontal length and open sky, became the setting for several choreographic compositions by Maurice Béjart: the Greek Suite, the Act

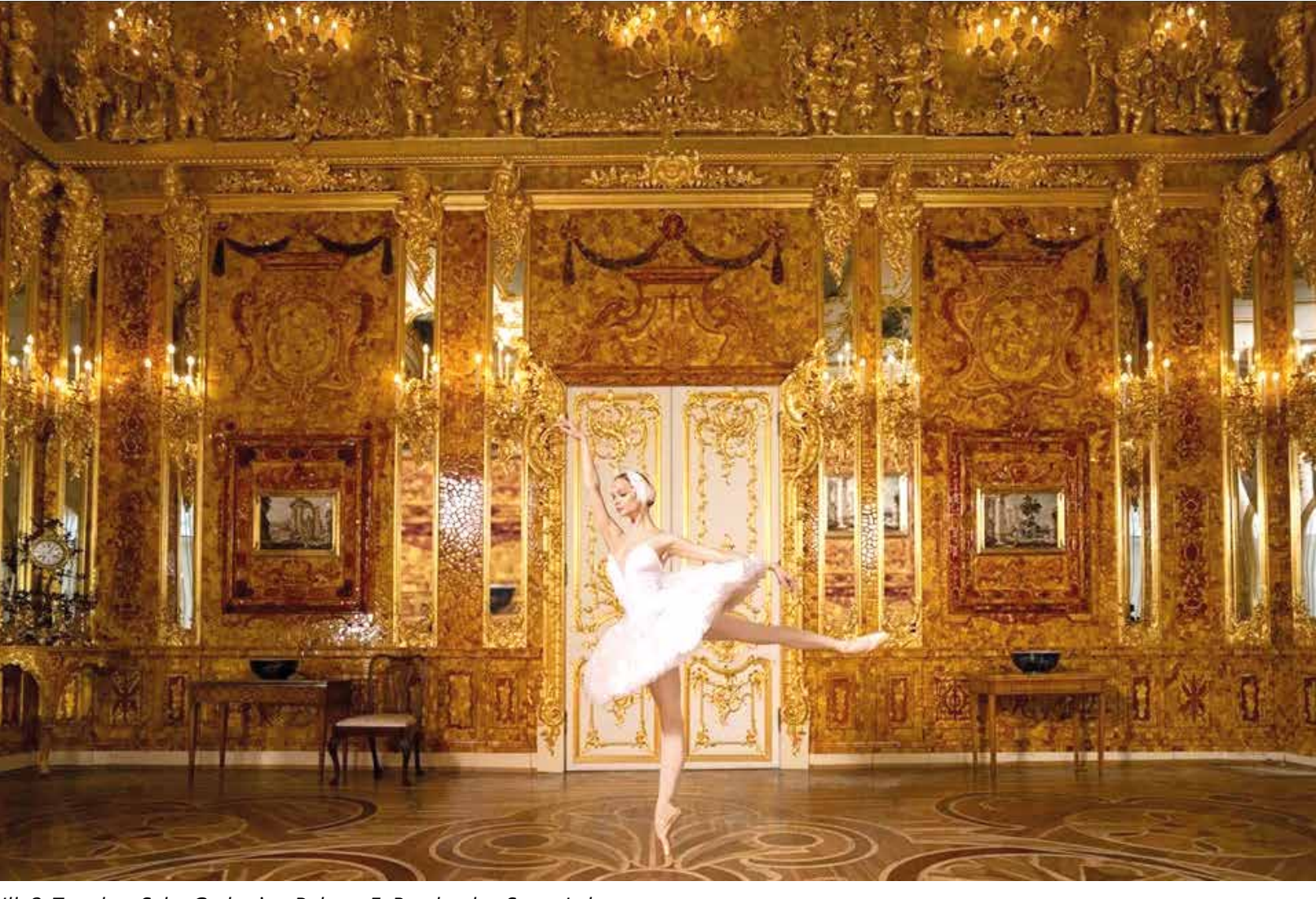

II. 2. Tsarskoe Selo. Catherine Palace. E. Borchenko. Swan Lake

of Shadows from La Bayadère, etc. It was because of its classical exemplarity with the silhouette of the Peter and Paul Fortress in the background that the embankment became a true source of inspiration for Béjart. Here, it is appropriate to address the question of the field and the boundaries of the choreographic image in relation to architecture. After all, in a traditional three-dimensional box dance, action is formed within the given boundaries of the stage portal. In the open air, though, new means for its compositional and narrative deployment methods became available. So, the attraction of architecture to dance was also expressed in the desire of choreographers to experiment with individual structures. The main conceptual direction in the choreographic piece The Knight in the Panther's Skin after the Georgian epic poem by Shota Rustaveli was the tectonic idea: the co-subordination of compositions and dance angles with the aesthetic principles of tectonics and the heroized scale of the architectural forms of the Kazan Cathedral colonnade. The through colonnade allows you to see the entire composition of the semicircular platform and the structure itself, in which the dance is blended with its plastic stereometricity. There is a direct correlation between this greatness and the scale of the changing mass of figure groups of performers, and the stability of the composition in which they realize their being. The synthetic integrity of the monumental style is clearly evident in this piece. The fragments of ballets Vain Precautions and The Creation of the World performed by the French artists of the company Ballet XXV were blended in the light cheerful structure of a landscape park in Saint Petersburg, leaving the stereotypical enclosed space behind and entering the new pictorial and metaphoric structures.

Recently, choreography has tactfully entered the natural space without disturbing the visual connections to the established architecture. Such are the productions of dances and full performances in the open air against the backdrop of architectura structures: Zeus by Andrey Petrov in the ruins of the Temple of Zeus in Olympia (Greece), choreographic numbers shown against the silhouette pattern of the Eiffel Tower in Paris, etc. The need for successful dance obliges the stage director to constantly keep the conditions of the scene in mind. These conditions are not just a formality. They are predetermined by the inner nature of the drama itself The emphasis shifts here due to some deviation from the norm when the viewer's gaze is turned of architectural style comes to the fore. The style primarily to the theatrical action, and the concep 
of architectural environment and the style of choreography are in close relationship with each other. The previously conventional three-dimensional space of the stage box lost some conventionality, though the nature of the choreographic image was not harmed. The uniqueness of the architectural object and the artistry directly related to it influenced the structure of the dance images decisively, so the principle of harmonization became dominant. The requirement for harmonious unity of architecture, space, the artist, and the viewer becomes the principal concept of forming this environment, to influence the feelings. In the uni-

REFERENCES

1. Berezkin, V.I. 2013. The art of scenography of the world theater. Volume 3. Masters of the $16^{\text {th }}$-20 th centuries, Moscow, p. 296

2. Yesaulov, I.G. 2005. Introduction to the aesthetics of classical choreography. Letters to J. G. Noverre, Izhevsk Udmurt University, p. 223

3. Noverre, J.G. 2007. Letters about dance, p. 382

. Vanslov, V.V. 1997. Grigorovich's ballets and matters of choreography, Moscow, p. 302

5. Dubnik, I.O. 1984. The specifics of artistic imagery in choreographic art: an abstract of the dissertation Moscow, p. 22

6. Kondratenko, Yu. 1999. "Synthesis in the choreographic art of the postmodern era / Yu. Kondratenko", The voice of the artist: the problem of synthesis in modern choreography: Materials of the international conference, Volgograd, pp. 16-20.

7. Churko, Yu.M. 1999. The line going to infinity: Subjective notes on modern choreography, Minsk, p. 224

8. Vychuzhanova, L.K. 2009. The language of choreography: philosophical analysis. The abstract of the dissertation for the degree of candidate of philosophical sciences, Ufa, p. 20

9. Gerasimova, I.A. 1998. Philosophical understanding of dance, Questions of philosophy. - 1998, no. 4, p. 50-63. 10. Rappaport A.G. 2012, "Space and substance", ACADEMIA, no. 2,3. pp. 20-23

11. Lebedeva, G.D. 2007. Ballet, semantics and architectonics, St. Petersburg, p. 160

2. Gerdt, O. 1999. Territory of possibilities in motion Netherlands' Institute of Theater, Moscow, p. 28 versality of ancient architecture and dance, their originality blossomed.

Today, the phenomenon of design is perceived not only from the perspective of architectural creativity but also as an integral characteristic of any contemporary creative art form. We have observed this phenomenon in the area of dance practices at various stages of choreographic activity. The very staging work of the choreographer itself, like that of the architect, can be designed in computer programs now, prompting us to talk about the deconstruction of artistic perception and other methods of working with spatial stage composition.
Татьяна Васильевна Портнова доктор искусствоведения, профессор ФГБОУ ВО «Российский государственный университет

им. А. Н. Косыгина» e-mail infotatiana-p@mail.ru Москва, Россия

ORCID ID: 0000-0002-4221-3923
13. Dutsev, M. V. Integration of art into the latest architecture [electronic resource]. URL: https://bibl.nngasu.ru/ electronicresources/uch-metod/architecture/850493. pdf (accessed: 25.07.2021)

14. Gelfond, A.L., Dutsev M.V. 2010. "Architectural and artistic synthesis as a means of dialogue", Privolzhsky Scientific Journal, N. Novgorod: NNGASU, no. 4, pp. 147-152.

15. Hakobyan-Shupp, R. 1999. "Global dance: the creative process, the development of a new sphere of dance", The voice of the artist: the problem of synthesis in modern choreography: Materials of the international conference, Volgograd, pp. 41-51

16. Evin, I. A. 1993. Synergetics of art, Izhevsk, p. 171.

17. Portnova, T.V. 2014. "Architectonic principles in ballet (Dialogue of arts in a spatial environment)" International Journal of Experimental Education, no. $1-2$, p. 170

18. Remez, O. Ya. 1982 Mise en scène and stage action Moscow, GITIS, p. 103

19. Alone with time. (Interview with Maurice Béjart). 1995. Musical life, no. 7-8. p. 7-8

20. Portnova, T.V. "The category of space and the principles of architectonics in the structure of a ballet performance", space and time: theories, concepts, paradigms, vol. 3, no. 2, p. 7

21. Ikonnikov, V.A. 1983. The artistic language of architecture. Problems of space and architecture Moscow, p. 8

22. Portnova, T.V. 2014. "Architectonic principles in ballet (Dialogue of arts in a spatial environment)" International Journal of Experimental Education, no. $1-2$, p. 174

DOI: 10.36340/2071-6818-2021-17-4-79-90

\section{АРХИТЕКТУРНОЕ ПРОСТРАНСТВО В ТАНЦЕ КАК ХУДОЖЕСТВЕННО-ОБРАЗНАЯ СИСТЕМА}

Аннотация: В ходе исследования рассматриваются выразительные средства танца и архитектуры устанавливаются общее и специфическое в природе их художественного языка, выявляются степень взаимодействия архитектурных принципов с танцевальной драматургией и хореографической композицией, анализируются примеры интерпретации танцевальных постановочных решений в архитектурном пространстве. Анализируются вудожегектурном пространсте. Анализируются художебалетмейстерских решений, происходящие в разбалетмейстерских решений, происходящие в разс перспективизма декораций на сценической плос парспективизма декораций на сценической плоцадке и световой архитекуры XVII в. автор переобстановочного спектакл XIX в. ихореографическим экспериментам начала XX в. B стате ор стся, что наиболее интереснве проектн отн, что а с мел сорег, ориги иальных приемов взаиморействия хореогр ории и архитектры постановки танцев

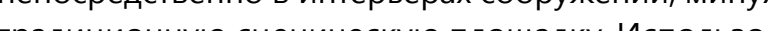
традиц ион не сценическуо площа иу. Истользоохная идея движения человека в пространстве, охват идещ ая зритела, появляется здесь в резульТа

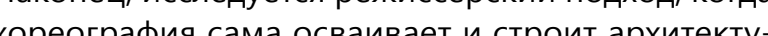

Танец в архитектурном пространстве - сложная, многоаспектная проблема, находящаяся на пересечении искусства, философии и инженерных технологий. Настоящее исследование рассматри вает данную тему как художественно-эстетическую категорию в контексте выразительных средств хореографического искусства, находит своё творческое осмысление и многообразие форм художественного отображения пространства посредством танца. ру, помогая зрителю ощутить себя словно внутри собственной пространственной структуры. Этот своеобразный художественно-визуальный синтез предстаёт в динамике жанрового и стилевоо авторского сценического контекста. Изучение специфики балета как зрелищного явления представляется насущной исследовательской задачей, тосколу именно балет, как никакой другой жанр и рального искусства, оставил в наследии XX нотан, вероятно, XXI веку чрезвычайно разцы пространственно-сценического творчества Проблема интерпретаци танца творчества. ном пространстве как самостоятельний предмет исследования имеет важное значение в связи со структурой и эволюиией художественного обра за в современном хореогра иическом искусте а ва фоне постмо хорностких совком искусстве лев

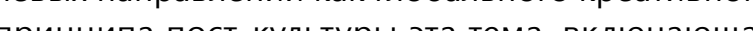
стано шир одной из клочические ассоциации, художественного пр

архитектурное пространство К совенно-образная система, синтез архитектуры и танца.

Если проблемы морфологии танца, его языковой природы достаточно освещены в современной научной литературе, то вопрось архитектурного пространства как необходимой субстанции, существующей в хореографическо искусстве, становятся редким объектом внимания исследователей. Сценическое пространство, от его истоков до нового времени, формируе мое методами сценографии, являлось предме том анализа В. Березкина [1]. Пространство как 
выразительное средство в композиции танца изучается будущими балетмейстерами в учебных курсах, что позволяет сформировать осознанное отношение и мотивацию в работе со сценографическим целым. Ж. Новерр рассматривал сценическую площадку как геометрическую систему в контексте понимания композиционной деятельности танцмейстера и организации элементов танца с целью создания стройной гармонии хореографического сочинения [2; 3$]$.

Поставленная в настоящей статье проблема второстепенным образом затрагивается в балетоведческой литературе в связи с размышлениями теоретиков танца, а также в контексте творчества ряда хореографов: М. Петипа, М. Фокина, К. Голейзовского, Л. Якобсона, Ю. Григоровича, Б. Эйфмана, М. Грэхем, М. Р. Фон Лабана, М. Каннигрехэм, М. Бежара, Е. Панфилова,-отразивших в своём творчестве концептуальное, художественно-пространственное видение природы танца $[4 ; 5 ; 6]$. Их мнения сходятся в том, что пространство является своеобразным объектом хореографического содержания, которое приходится каждый раз заново интерпретировать. Описанные Е. Чурко приёмы современной хореографии функционируют в контексте эстетики перформативности как пути образования новых связей между элементами художественно-пространственной композиции, а также в отношении зрительского восприятия [7].

Значительная группа исследований рассматривает театральное пространство как философскую категорию $[8 ; 9 ; 10]$. Так, Г. Лебедева, оперируя понятиями балет, семантика, архитектоника с позиций системного подхода и синергетической парадигмы, анализирует пространственно-временные параметры балетного спектакля и специфику взаимодействия составляющих его компонентов [11]. О. Гердт в исследовании «Территория возможностей. В движении» предлагает рассмотреть изменчивую природу актёрской пластики, которая позволяет проявляться различным простра ная в пространственную среду, может раскрывать множественность путей понимания театрального образа, а также даёт потенциал для возникновения новых отношений к его содержанию [12]

Сейчас можно встретить размышления об интегративном принципе современной архитектуры: «Многоэлементные формы творчества прежде всего, театр, кино, телевидение, современная хореография, соотносятся с актуальны- ми архитектурными тенденциями «режиссуры» и «зрелищности». Несмотря на условность такого родства, ряд явлений и подходов сферы зрелищных искусств можно охарактеризовать как актуальные принципы архитектуры: сценарность подчеркнутая визуальная выразительность, выстраивание объёмов и пространств как «мизансцен» спектакля, архитектурность «декорации», смена «кадров» пространственных впечатлений в движении» [13]. Действительно, искусство архитектуры, так же, как и искусство танца, издав на следует закону художественной интеграции а архитектор и хореограф применяют художе ственный синтез как разновидность комплексного интеграционного метода профессиональной деятельности $[14 ; 15 ; 16]$

Вместе с тем, несмотря на приведённые источники, полноценный аналитический подход с позиций архитектурной составляющей балетного произведения в искусствоведении остаётся несформированным.

Методологическая концепция исследова ния основана на принципах целостного изучения функционирования танца в архитектурном пространстве: от философско-эстетических, художественно-образных до языково-стилистических вопросов его рассмотрения. Исследуя некоторые исторические аспекты синтеза танца и архитектуры, мы оцениваем события и явления театральной жизни с современных позиций, учитывая, что избранная тема - содружество драматурга, режиссёра и архитектора - имеет непосредственно значение для творческой практики наших дней и актуальна не только для российского, но и для мирового многонационального театра.

В основе любого хореографического спектакля должна лежать прочная архитектоническая конструкция. Ещё К. Станиславский высоко ставил искусство мизансцены, требовал точной схемь перемещений актёра в пространстве. Он называл актёра инженером, архитектором роли. «Хореографический образ не может существовать без пространственной структуры, без найденного продуманного конструктивного принципа, определяющего пульс всей постановки. Корде балетные массы, разнообразно формирующиес в ходе спектакля, также образуют пространственную среду и обладают своего рода тектоникой. Архитектоника балетного спектакля состоит и двух вербальных компонентов. Один уходи в изображение, художественное оформление, организацию пространства, а другой сохраняется в танце» [17: с. 170]. С. Я. Ремез отметил: «Режиссура - искусство строительное» [18: с. 103] спектакля - увлекательная, но не простая задача для хореографа.

Возникшая в Италии в XVI в. сцена - коробк в обстановке придворных архитектурных представлений и примитивные ярмарочные подмостки, на которых бродячие актёры увеселяли народную толпу, собравшуюся на площади, создали две системы театральных пространств, которые можно обозначить как замкнутое и открытое Замкнутое, существующее на сцене, внутри интерьера театрального здания, и открытое, распространившееся на природно-архитектурную среду. Французский хореограф М. Бежар характеризовал архитектуру как искусство, серьёзно влияющее на балет: «Я много работал с архитекторами, может быть, не с очень знаменитыми. Они мне создали новое сценическое пространство, составляющее важный элемент спектакля. Mои самые лучшие спектакли идут на итальянской сцене с поднимающимся в глубине полотном. У меня сцены каждый раз оборудованы по-разному» [19: с. 7-8].

Начиная С XVI в. на сцене развиваются приёмы перспективизма, способные зрительно углубить архитектонику сценического действия. Даже ус ловно-абстрактные декорации с изображением архитектурных строений могут подчеркнуть и усилить пространственно-зрительную разработку спектакля, взаимную обусловленность танцовщи ков и среды. Сопоставление линейной перспективы в двухмерной декорации эпохи Ренессанс с пространством реальной архитектуры невольно приводит к иллюзорному сближению онтологических систем этих видов творчества.

Можно наблюдать иную концепцию пространства, основанную на взаимоотношении световой архитектуры и танца,- это вовсе не изобретение современной эпохи. Она уже была заложена в скрытом виде в образной структуре усадебной архитектуры царских увеселительных резиденций XVIII в. Москвы и Санкт-Петербурга: Царицыно, Архангельского, Кусково, Останкино, Петергофа, где момент театрализации был особо значим. Сама архитектура этих ансамблей с их регулярными планировочными принципами была рас считана на театрализованную пространственную игру, смену процессий и также приобретала теа- тральный характер. Садово-парковая архитектура того времени считалась равноценным искусством, наряду с другими. Феерия, создаваемая декоративным характером цветных фонарей, рождала образ иллюзорной световой архитектуры, стала генератором развёрнутого пространства, хотя ещё и не достигла в плане его организации геометризированной логики световых лучей, подобной современной сценической аппаратуре. При этом здесь же следует учитывать условность стилевых характеристик самих архитектурных ансамблей и отсутствие чётких границ между ними. Иногда архитекторы, садовники и организаторы театрализованных мероприятий сочетали черты разных стилевых направлений, работали на их стыке, исходя из декоративно-эмоциональных принципов, а не из функционально-технических дополняя таким образом структурную пластику орнаментальной.

Монументальное построение большого обстановочного спектакля М. Петипа и Л. Иванова конструктивистские эксперименты К. Голейзовского, движение танцевальных форм, их трансформация и сопоставление у Дж. Баланчина - все это примеры использования различных пространственных систем. Фигуры артистов сами создают архитектуру, ориентируют зрителя на собственную пространственную структуру. Танцу ющие у М. Петипа и Л. Иванова тяготеют к сим метрии форм, синхронной ансамблевости, при этом сохраняя живую непосредственность каждого образа. Кордебалетные группы «Лебедей», «Виллис», «Теней» в «Лебедином озере», «Жизе ли», «Баядерке», выстраиваясь параллельными диагональными и иными рядами на планшете сцены, словно генетически создавали ту удиви тельную геометрию танца, без которой хореографию этих балетов представить невозможно. Хореограф-экспериментатор начала XX в. К. Го лейзовский часто приводил актёрские группы к элементарной схематической простоте. Вер тикальное, а не горизонтальное, как у Л. Иванова и М. Петипа, направление, приобретаемое з счёт сверхусложнённости, развивалось ввысь. В оформлении он использовал лестницы, мость и другие архитектурные элементы (здесь происходило взаимодействие архитектонической структуры оформления с тектоникой фигур ар тистов в пространстве). Это было самое крайнее проявление хореографического тектонического рационализма (1920г.), обнаженная конструк- 
тивность которого была так созвучна архитектурным поискам того времени. В этом своём виде абстрактные бутафорские строения находят себе место как предметное наполнение сценической среды и воздействуют в унисон с рационалистской архитектурой как связанные с ней элементы, привносящие в хореографию свой конструктивно-объёмный акцент.

«Примером смелого и оригинального приёма взаимодействия хореографии и архитектуры может служить постановка танцев непосредственно в интерьерах сооружений, минуя традиционную сценическую площадку. Идея движения челове ка в пространстве по направлению из зала в зал, волнение, охватывающее зрителя в результате смены конкретных, последовательно меняющихся впечатлений, наглядно были раскрыты в постановке хореографических миниатюр Л. Якобсона в залах музея керамики усадьбы «Кусково». Основой композиции стало открытое пространство, анфилада залов, не имеющих чётко очерченных границ и симметричных осей, но в то же время подчинённых определённой ритмической закономерности. Это пространство не топографическое и не математическое, а живое и действующее. Движение танца переходит из одного зала в другой. Здесь присутствует энергичное развертывание действия, резкое чередование сцен, быстрая смена фонов, обыгрывание деталей, ракурсный взгляд. При движении взгляда в поле зрения попадают многочисленные архитектурные элементы и детали (двери, проёмы, окна, колонны, люстры, декорации и т.п.), участвующие в создании внутреннего эмоционального настроя. Контрасты пространств, форм, фактур, направлений рождают ту множественность впечатлений, которая постоянно притягивает зрителя, не утомляя его однообразием» [20: с. 7]. Принцип развёртывания пространств, построенный на их последовательной смене, приобретает особую структурную значимость и развитую семантику в формате кинематографической демонстрации хореографических номеров.

Следует заметить, что принцип совмещения в изображении различных зрительных позиций был открыт задолго до появления кинематографа. Американский архитектор Ф. Джонсон предложил концепцию «профессиональной» архитектуры утверждая, что проектирование пространства и лепка объёмов лишь дополнительны к главному - организации процессов. По его мнению, красота заключается в том, как мы движемся в пространстве.

Теоретик архитектуры А. Иконников в отве на это пишет: «Такая точка зрения может показаться парадоксальной, но одну из граней специфики архитектуры она подчёркивает весьма убедительно» [21: с. 8]. На этом примере можно с особой полнотой почувствовать и постичь ту органичность художественного мышления, редкое умение хореографа Л. Якобсона гармонично соединять различные виды искусства в единую материю согласованного ансамбля.

«Во второй нетрадиционной театральной системе открытого пространства хореография осваивает архитектуру не только в сосуществовании она сама, как мы констатировали, строит архитектуру, помогая зрителю ощутить себя словно внутри собственной пространственной структуры. Такую попытку пластически-архитектурного осмысления осуществил М. Бежар, работавший с французской и русской труппой в Санкт-Петербурге. На фоне набережных Невы, Михайловско го замка, Петропавловской крепости, Казанского собора, Невских мостов рождались незабываемые хореографические образы, словно наполненные атмосферой современного города» [22: c. 174]. Панорамный фон северного города, рассчитанный на естественное созерцание природь словно означал исчезновение архитектурной де корации, существовавшей ранее в театральной живописи. Водное пространство Невы с её гори зонтальной протяжённостью и открытым небом стало местом для демонстрации ряда хореографических композиций М. Бежара - «Греческой сюиты», акта Теней из «Баядерки» и др. Именно в силу своей классической идеальности с силуэтом Петропавловской крепости на заднем плане набережная стала для М. Бежара истинным источником вдохновения. Здесь по отношению к архитектуре уместно затронуть вопрос о поле и границах хореографического изображения. Вед в условиях традиционной трёхмерной коробки танцевальное действо формируется в заданных границах портала сцены, на открытом воздухе оно получило возможность найти средства для сво их приёмов композиционного и сюжетного развертывания. Так, тяготение архитектуры к танцу выражалось и в стремлении балетмейстеров экспериментировать с отдельными сооружениями Основной концептуальной установкой в хореографическом номере «Витязь в тигровой шкуре на тему грузинской легенды Ш. Руставели являлась художественно-тектоническая идея, соподчине ние композиций и ракурсов танца с эстетическими принципами тектоники героизированным масштабам архитектурных форм колоннады Казанского собора. Сквозная колоннада позволяе видеть всю композицию полукруглой площадки и само сооружение, в которые вписан танец с его пластической стереометричностью. Между этим величием и масштабом меняющейся массы фигурных групп исполнителей, устойчивостью композиции, в которой они реализуют своё бытие, оказывается прямая зависимость. В этом номере ярко проявилась синтетическая целостность монументального стиля. Фрагменть балетов «Тщетная предосторожность» и «Сотворение мира» в исполнении французских артистов труппы «Балет XX века» были словно вписань в светлый жизнерадостный строй пейзажного парка Санкт-Петербурга, отошли от стереотипного замкнутого пространства и вышли в новые живописно-образные структуры.

В последнее время хореография тактично входит в естественное пространство, не нарушая визуальных связей со сложившейся архитектурой. Таковы постановки танцев и целых спектаклей на открытом воздухе на фоне архитектурных сооружений: «Зевс» А. Петрова в руинах храма Зевса в Олимпии (Греция), хореографические номера, показанные на фоне силуэтного рисунка Эйрелевой башни в Париже и др. Необходимость действенного танца обязывает режиссёра-постановщика постоянно помнить об условиях сцены.
Эти условия имеют не формальное значение. Они предопределены внутренней природой самой драматургии. Некоторое отклонение от нормы когда взгля зрителя обращён, прежде всего, на театральное действо, здесь акценты смещаются, понятие архитектурного стиля выходит на пер вый план. Стиль архитектурной среды и стиль хореографии находятся в тесных отношениях друг с другом. Условное трёхмерное пространство сценической коробки сделалось менее условным это не разрушило природу хореографического изображения. Уникальность архитектурного объекта и непосредственно связанная с ним художественность решительным образом повлияли на структуру образов танца, доминирующим стал принцип гармонизации. Требование гармонического единства архитектуры, пространства, арти ста и зрителя, с целью воздействия на его чувства становится основной концепцией формирования этой среды. В универсуме старинной архитектуры и танца стала ощущаться их оригинальность. На сегодняшний день феномен проектирования воспринимается не только с позиций архитектурного творчества, но и как неотъемлема характеристика всего современного креативного искусства. Это явление мы наблюдали в сфере танцевальных практик на различных этапах хореографической деятельности. Сама постановочная работа хореографа, как и архитектора, начинает моделироваться в компьютерных программах когда можно говорить о деконструкции художественного восприятия и других методах работ с пространственной сценической композицией. 


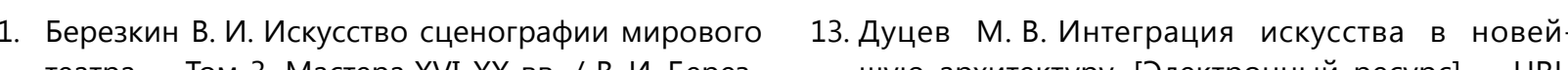
театра. - Том 3. Мастера XVI-XX вв. / В. И. Берез кин.-М.: Едиториал УРСС, 2013.- 296 с.

2. Есаулов И. Г. Введение в эстетику классической хореографии. «Письма к Ж. Ж. Новерру» / И. Г. Есаулов.—Ижевск: Удмуртский университет, 2005. $223 \mathrm{c}$.

3. Новерр Ж. Ж. Письма о танце / Пер. с фр. под ред. А. А. Гвоздева. -2-е изд., испр.-СПб:. Лань, 2007.$382 \mathrm{c}$.

4. Ванслов В. В. Балеты Григоровича и проблемы хореографии / В. В. Ванслов.-М.: Искусство, 1997. $302 \mathrm{c}$.

5. Дубник И. О. Специфика художественной образности в хореографическом искусстве: автореферат дис. / И. О. Дубник.-М., 1984.- 22 с.

6. Кондратенко Ю. Синтез в хореографическом искус стве эпохи постмодерна / Ю. Кондратенко // Голос художника: проблема синтеза в современной хореографии: Материалы международной конференции.-Волгоград, 1999.-С. 16-20.

7. Чурко Ю. М. Линия, уходящая в бесконечность: Субъективные заметки о современной хореографии.-Минск: Полымя, 1999.-224 с

8. Вычужанова Л. К. Язык хореографии: философский анализ: автореферат диссертации на соискание ученой степени кандидата философских наук / Л. К. Вычужанова. -Уфа, 2009.- 20 с.

9. Герасимова И. А. Философское понимание танца / И. А. Герасимова // Вопросы философии. - 1998. № 4. - С. 50-63.

10. 10. Раппапорт А. Г. Пространство и субстанция / А. Г. Раппапорт // ACADEMIA. - 2012. - № 2, 3.C. $20-23$

11. Лебедева Г. Д. Балет, семантика и архитектоника / Г. Д. Лебедева.-СПб.: Лань, 2007.- 160 с

2. Гердт О. Территория возможностей. В движении. Институт тетра Ния воландов / О. Герлт- - М. 1999. C. 28 шую архитектуру. [Электронный ресурс].- URL: https://bibl.nngasu.ru/electronicresources/uch-metod/ architecture/850493.pdf (дата обращения: 25.07.2021) ственный синтез как средство диалога / А. Л. Гельфонд, М. В. Дуцев // Приволжский научный журнал.—Н. Новгород: ННГАСУ, 2010. — № 4.-С. 147 152.

15. Акопян-Шупп Р. Глобальный танец: творческий процесс, развитие новой сферы танца / Р. Акопян-Шупп // Голос художника: проблема синтеза в современной хореографии: Материалы международной конференции.-Волгоград, 1999.-С. 41-51.

6. Евин И. А. Синергетика искусства / И. А. Евин.-М. Ижевск: РХД, 1993.-С. 171

17. Портнова Т.В. Архитектонические принципы в балете (диалог искусств в пространственной среде) / Т. В. Портнова // Международный журнал экспериментального образования. - 2014. - № 1-2. C. 170.

8. Ремез С. Я. Мизансцена и сценическое действие С. Я. Ремез.- М.: ГИТИС, 1982.-С. 103.

19. Наедине со временем (Интервью с М. Бежаром) // Музыкальная жизнь. - 1995. — № 7-8. - С. 7-8. 20. Портнова Т.В. Категория пространства и принципы архитектоники в структуре балетного спектакля // Пространство и время: теории, концепции, парадигмы.-Т. 3.-Вып. 2.-С. 7.

21. Иконников В. А. Художественный язык архитектуры Проблемы пространства и архитектуры / В. А. Иконников.-М.: Искусство, 1983.-С. 8.

22. Портнова Т.В. Архитектонические принципы в балете (диалог искусств в пространственной среде) / Т. В. Портнова // Международный журнай экспериментального образования._- 2014. - № 1-2.C. 174. 14. Гельфонд А.Л., Дуцев М.В. Архитектурно-художе-

Ph D., Associate Professor at Faculty of Communications, Media, and Design HSE Art and Design School, Academic Director of the Doctoral School in Arts and Design at the Higher School of Economics Research University (Moscow)

e-mail: lalyabieva@hse.ru

Moscow, Russia

ORCID0000-0001-7795-2059

ResearcherID Z-1306-2019

Irina M. Sakhno

Doctor of Philology, Professo

Department of theory and history of culture, RUDN University, Moscow Academic Supervisor, Masters Program "Practices of Contemporary Art

Faculty of Communications, Media, and Design

HSE Art and Design Schoo

e-mail:sakhno im@pfur.ru

Moscow, Russia

ORCID0000-0002-5510-6684

ResearcherID B-2047-2016

Scopus Author ID57196349789

Tatiana E. Fadeeva

$\mathrm{PhD}$ in Art history, Associate Professo Faculty of Communications, Media, and Desig

HSE Art and Design Schoo

e-mail: tfadeeva@hse.ru

Moscow, Russia

ORCID0000-0002-6754-4235

ResearcherID Z-2521-2019

DOI: 10.36340/2071-6818-2021-17-4-91-109

\section{PRACTICE AS RESEARCH: CREATIVE AND RESEARCH PRACTICE IN THE FORMAT OF POSTGRADUATE EDUCATION}

Summary: The authors of the article focus on the discussion format of practical research. In recent years, practice as research has become a direction of research activity in foreign universities and an object of close attention from the Russian academic community. Representatives of various disciplines in art and the humanities convincingly argue the need for such a format of creative practice in performance, theatre, dance and contemporary art. Practice as research includes different forms and ways of representing applied and project art products. Today, a practising researcher causes controversy and discussion since the model of creative practice as a method of studying art is an al format. Also, the parameters of evaluating practica research, the relationship between theoretical, purely research, and creative material cause significant difficulties. The methodology based on practice and the parameters of the assessment of practice as research give rise to a lively discussion. The situation in arts and humanities teaching is complicated because practice-re lated research has been labelled as field research and engineering for a long time. Artistic practice in contemporary art and design has recently become the object of close attention at the Graduate School of Art and Design at the Higher School of $E c 0$ 
the practical focus of visual research is the main direction in educational bachelor and master's programs. A new understanding of art as a practice and, at the same time, research can shed light on many topics, including cultural anthropology, psychology, sociology, etc. That is why we defend the idea of the interdisciplinarity of such studies in our article. Artistic practice as a field of academic research and new experience in postgraduate education is at the centre of our study. We strive to generalise the experience of European educational programs, expand the range of methodological approaches and present the author's concept. Practice and research have long been inseparable in many humanities; project workshops and representation of creative artifacts are at the heart of contemporary art and design education. Modern Russian education is just beginning to explore new territory. In this sense, our collaborative research of an innovative format is designed to analyse

\section{Introduction}

In the European education system, in the arts and humanities departments, debates and discussions about the content of the not so long ago form of practical research take place. Practice as research eliminates the existing dichotomy between theory and practice in classical education and offers an entirely new educational format for our country. Today, the fact of the influence of practice on scientific research is evident. There are many models for researching practice: practice as research, expert-led practice, and research-oriented practice. The difficulty lies in the fact that the object of attention is the study of a project in arts. It becomes an independent element of the research process and at the same time, is executed as an artistic practice. Therefore, practice as research is not a methodology; it is rather a new toolkit for studying artistic and project activities. The very term "practice as research" seems to us somewhat vague, and in the academic environment, it is positioned as a wide range of activities without delineated boundaries. Practice as research can include many characteristics in its thesaurus: this is a research process, the results of which are formalized as artistic practice, this is the practical result of research in the format of an art project, or it is a theoretical study of the achieved practical results. Such an extended interpretation of artistic practice denotes many problem areas: where does the actual artistic practice begin and end, what is the relationship between theoretical and practical results, with the help of which methodology is such an integration of research and project activity possible? It is certain that practical research, based foreign experiences and formulate the need to promote new educational technologies within the framework of graduate school. The habitus of practice as research is such that research based on practice raises the question of the forms of critical activity and content param eters of a creative artifact and documenting research materials. The posed research problem in combination with practice demonstrates the originality of research. It expands the boundaries of the research field by introducing a hybrid methodology for evaluating a creative project and critical discourse. The task of the authors of the article is to identify a debatable problem field, an alyse analytical data related to the innovative scientific field and present essential strata of the new educational format, Practice as Research.

Keywords: Practice as Research, practising researche educational formats, postgraduate studies, creative competencies, HSE

today on various creative methods, can be included in interdisciplinary creative projects that are innovative in their content. Undoubtedly, such an educational format changes our understanding of the strategies for representing modern knowledge in art and humanities, expanding the space of existing knowledge. We can say that today practical research is a powerful driver for developing a new knowledge economy and an integral part of creative industries. Practice as research in contemporary art means the approbation of scientific results in the format of an artistic project. It expands the discursive field of modern knowledge in the arts and humanities. It is a peculiar form of cultural practice and the study of broad contexts: socio-politica and artistic. In addition, practice as research is the production of new types of intellectual and cultural products in creative industries.

It is important to note the open format of practica research. It is always a discussion field for academic reflections and experimental genres of performative practices, innovative representations of research projects. The European experience of performance research in many leading European universities is well known. For example, on the website of the PARIP laboratory of the Drama Department of the University of Bristol [13], one can get acquainted with the results of practice as research and related critical activities, see the implementation of effective digita documentation systems for live performance (dance theatre, drama) - archiving the material of practica research as the most important strategy in design and research activities. Expanding the range of different forms of practice as research, modifying the usual forms of critical activity and expanding the repository's capabilities are the most important parameters for assessing the activities of such laboratories.

In July 2020, the UK Arts and Humanities Research Council, which aims to coordinate projects in science and education, developed and published a Research and Development roadmap that outlined a long-term vision to unleash the potential of science, research and innovation. Practical research in arts and humanities occupies an important place in the future strategy for the development of science. It is considered a creative tool for innovative strategies and further interaction between science and art [4]. The HSE Graduate School of Art and Design was one of the first to address the issue of the need to create a similar format of education in Russian universities. Today, a new culture of research is in demand more than ever in the format of an inclusive national approach in all countries. Russia will have to comprehend innovations in the field of education and new global challenges. Thus, the discussion of practical and applied research seems to us timely and relevant.

Reflecting on the integration of approaches to the postgraduate curriculum, we see a unique concentration of educational platforms that combine universal and professional competencies paradigms. To determine the Russian trajectory of developmen and predict the final results of innovative educational technologies, it is necessary to take into accoun the successful practices and experience of European countries while proceeding from the goal setting and direction of the trajectories of the developmen of education in Russia in the new conditions of the creative and knowledge economy. The society of innovative information technologies produces knowledge in economics and business, and the educationa sphere. Formalised education is the knowledge and experience accumulated in the learning process that will subsequently demand the educational services market The genesis of the information society is inextricably linked with the new economy of knowledge particularly with the inclusion of modern education in the international context. Today, knowledge is continuously updated, new approaches and innovations the gole of scientific and intellectual activity is increasing. In this context, creative competencies as the ability for creative self-development, developing innovative ideas and producing new approaches are particularly important. R. Ep- stein was one of the first researchers who introduced the concept of "creative competence" into scientific circulation. He characterized this phenomenon as form of adaptation to new challenges of civilization and a person's readiness for independent learning self-development and self-improvement $[9$, pp.116 140]. Of course, today, in the face of new challenges, creative competence is the ability to generate new creative ideas that will be in demand in the coming decades. Adaptability and non-standard thinking incorporation of new knowledge into practical skills and artistic activity, independence in decision-making and the ability to act, the implementation of ac cumulated experience constitute the integrativeness of knowledge and the multifactorial nature of tasks that are necessary for assessing the quality of ed ucation and professional competencies of modern university graduates.

Today, the postgraduate level of education plays the most critical role in the technologies of designing creative competencies. A legitimate question arises: how to combine standards and individual scientific platforms and make art and design education com petitive? In our opinion, "Practice as Research" as form of academic research excludes the traditional dichotomy between theory and practice. Today, the scientific and academic community continues to debate how to correctly define the emerging phe nomenon, which habitual definitions (practice-prac tice, mixed practice research, practice-research) to prioritise. All agree on one thing: research in practice-oriented graduate schools should be subordinated to practical goals. Can artistic practice be recognised as research practice? After all, any project has a conceptual basis, goals and objectives, relevance and novelty. Increasingly, foreign scientists and educators are turning to such a concept as "practical research". In 2007, the UK Arts and Humanities Research Council published a paper on practical research in the arts, design and architecture [15] which served as a basis for discussions on the issue of practice as research. The emerging definitions of practice-based and practice-led only complicated the methodology for evaluating practical research since research based on practice and research im plemented in practice are difficult to classify clearly. Undoubtedly, it is essential for us that the international community has recognised the need for a research component in practical projects.

L. Candy tries to eliminate all contradictions by reflecting on "research-based practice" and "re- 
search-led by practitioners", the main criterion of which should be the parameter of generating original ideas [7]. In any case, we are talking about a research project with different formats for its implementation. Today, practice as an integral part of the research process with documentary evidence and textual analysis represents the newest educational format. New approaches and requirements for qualification parameters indicate the need for critical reflections and an original scientific idea, which is very important for any methodology of scientific research. According to L. Candy, in the format of practical research within the framework of a doctoral degree, it is necessary to "contextualise creative work" [7], the degree of its originality and the researcher's contribution to the scientific landscape of the subject area. It is pretty evident that the space of "practical research" cannot be strictly defined, especially if we are dealing with an applied design phenomenon or the research field of contemporary art.

Practice as research, or practical research is a relevant field of professional discussion in educational and scientific discourses today. We are dealing with different blocks of theoretical and practical knowledge, with varying parameters for assessing the levels and types of practices. The gap in formulation and the lack of a unified approach are apparent One cannot but agree with Rachel Hann, a teacher of scenography at the University of Surrey, who says that the time has come to unify all approaches to the definition of "practical research" $[10, p .5]$ and that the very formula "practitioner-research$\mathrm{er}^{\prime \prime}$ is just a temporary measure. The UK was at the forefront of a system for evaluating the effectiveness of advances in practical research. This scale of differentiation, the Research Excellence Framework (REF), is an essential characteristic of recognizing lecturers' and research results effectiveness. It is the rating of schools and faculties that determines the level of funding for projects. Today, it is becoming quite apparent that practical research is expanding its space. We can talk not only about the legitimisation of the practice of artists but also about broader integrative competencies in various fields of contemporary art. Practical research is becoming multifunctional, affecting many interdisciplinary research fields. Practical research is showing its vitality today, yet there remains a "petra scandali" for academic assessment and framework documentation

The question of the forms of representation and methods of articulating the project's results and its research matrix remains a subject of debate. In what format can the methodological focus be presented? In what form should the repository of research objects (documentation, images, video formats, interdisciplinary representations, etc.) be organized using digital platforms and university sites? How importan is the project repository? An essential component of practical research, in our opinion, is not only the demonstration of all the results achieved but also the opportunity to share them with a non-academic audience. The "practicing researcher" is a new format for modern academic education, and, therefore, the bias towards this form of self-positioning by artists and designers is obvious and often criticised. Today it seems likely that a line will be drawn between "academic research" and "practical research" since the method and tools of research differ sig nificantly. It is difficult for our academic community to understand that a "practising researcher" is also a scientist. At the same time, in our opinion, it is not worth inventing new methods and ways of articulating the main content of the project; research experiments should be understandable not only to the academic but also to the non-expert audience. This conclusion is supported by the practice and re sults of the first wave of practical research despite the controversy about research ecology.

Another undoubtedly significant problem is the documentation and archiving of practical research the embodiment of the main results of a practica project in scientific articles and monographs. The future of this innovative scientific format depends on this. Today, practical research requires us to rethink the scientific methodology and expand the space of alternative educational platforms and new discursive practices. The artist and designer's own practice and research experience is an important parameter. The same can be said for performing arts departments. Today, in Europe and the Unite States, the issue of the institutional status of practical research and its inclusion in government funding programs is actively discussed. Obviously, the latest practices in contemporary art and design can be labelled only in the context of practice as research and a representative model for the approbation of scientific results. Bridging the gap between fundamental and practical research in art and design is not an easy task and requires systemic thinking and certain courage. In this sense, new formats of postgraduate studies, including PhD by Practice, seem to us the most promising.
Representation Strategies for Practice-oriented Postgraduate Programs in European Universities

Returning to the issue of various forms and strategies of representation of practice-oriented postgraduate programs, it should be noted that many of them have existed for more than a year. For example, the PhD in Practice Program [3] of the Vienna Academy of Fine Arts (Vienna), one of the leading institutions in the field of art and design, has existed for ten years (since 2010) and has already established itself as a kind of an experimental "laboratory" that flexibly responds to the demands of both creative industries and academies. The curriculum description states that contemporary artistic practices are often based on critical epistemologies, as they were developed in accordance with feminist theories, gender studies, post-Marxist and post-colonial theories, etc. The social role of contemporary art and artists who research these topics is emphasised. Emphasis is placed on the epistemological and methodological foundations and perspectives of modern art The question of how artistic practices relate to critical issues of contemporary politics and culture and business is of particular interest to the program's developers. In this regard, we can mention the exhibition held in Venice in 2017. It was organized by the participants of the HAUNTOPIA/WHAT IF PhD in Practice Program, dedicated to "ghosts" — that is, events, signs, images, practices and objects that tell about the past and "produce" reflection about a possible future. In addition, "collaboration" projects seem promising, such as, for example, the PhD Arts Program, which is the result of collaboration between the Academy of Creative and Performing Arts of Leiden University and the Royal Academy of Arts in The Hague [13]. It seems that such joint projects will make it possible to use the resource base of the participating universities more efficiently. Interesting research initiatives such as, for example S. Tunka's project, Resonances Between Dance and Gnosis, [12] appear on the page "Individual Projects" of the website of the PhDArts Program.

In addition, the Nida Doctoral School (NDS), which implements an intensive program for DA and PhD applicants in visual and performative arts, design media and architecture, and the humanities, is of great interest The program involves close cooperation with outstanding practitioners in relevant fields, reports, discussion groups, presentations of doctoral research (formal, informal, performative, experimental, etc.), peer review, group and individual consul- tations. In 2019, NDS initiatives took place at the venues of the Venice Biennale - in the Lithuanian and Research pavilions [16], etc. The format of the research pavilion itself is of great interest. Here we observe a "counter" movement - from the academy to the world of art. The research pavilion is an international project organized by Uniarts Helsink with the support of the Louise and Göran Ehrnrooth Foundation, as well as Aalto University, Valand Academy of Arts at the University of Gothenburg, University of Applied Arts Vienna and Interlab Hongik University Seoul. Within this six-year-old pavilion (a revolving project implemented for the third time at the Venice Biennale), the emphasis is placed on artistic research. The goal of the project is to attract artists and researchers from all over the world to the pavilion sites, which is thought to be a catalys for establishing cooperation in the field of artistic research and a generator of "new thinking" (a new logic of interaction between the artist and the academy). For example, the current Research Pavilion (Research Pavilion No. 3) has a modular structure consisting of six research cells - spaces for paralle processes of exhibiting, conducting, demonstrating and discussing research. One of these "modules" is called Shelters ${ }^{1}$ and is devoted to the issues of function-oriented urban planning.

Without abandoning the specifics of the "traditional" postgraduate study (writing dissertation research), Western graduate schools in art and design seek to supplement it with a natural element for creative industries - design and practical activities, the so-called "practice". Thus, conceptually significant, weighty conclusions and decisions, usually of social significance, are formed into specific projects, taking into account the context of the socio-material world and transforming this context (which expresses the practical relevance of the dissertation research).

In Russia, the format of practice-oriented postgraduate study is practically unknown. There is no a single national postgraduate school in art and design where it would be implemented. What is more there is no understanding of this type of research activity in the particular scientific literature. Today, Russian education in this area is still focused mainly on extending the traditional academic paradigm.

The project is based on research conducted over the past three
years with the Arts Research Center at Hongik University and years with the Arts Research Center at Hongik University and
the Interlab. It involves artists, curators, architects, engineers and philosophers in the research team 
Many art universities (for example, the Moscow State Surikov Academic Art Institute at the Russian Academy of Arts, the St. Petersburg State Lomonosov Academic Institute of Painting, Sculpture and Architecture and others) train specialists focused on work within the framework of academic art and do not pay enough attention to actual artistic practices, the specificity of which (in the light of modernist and postmodern transformations of art) is the understanding of the conditions of art production, as well as a wide range of issues related to the economic, political and cultural development of modern society.

On December 13, 2019, the School of Design hosted the second round table dedicated to the problems of contemporary education in the field of art and design in Russia and the world. It was the second meeting in a series of discussions initiated by the HSE Graduate School of Art and Design. Within the framework of this round table, colleagues from abroad shared their own experiences. In particular, Else Skjold, Associate Professor at the Department of Design and Sustainable Development Royal Danish Academy of Arts (Copenhagen, Denmark), presented successful research projects implemented in the PhD by Practice format at the Roya Danish Academy of Fine Arts (KADK). PhD research (DSKD) "Learning Through Materials. Developing Materials Science Teaching in Design Education" (2015) by Karen Marie Hasling was among the presented "cases". In it, the author attempts to answer how a renewed understanding of materials in design education can help students develop the skill of making informed material choices that support more sustainable solutions.

Also, within the framework of the round table new educational technologies were announced in a speech by Barbara Brownie (University of Hertfordshire, UK), who shared her experience of successful implementation of this kind of "symbiotic" projects, in which practice and theory contribute to mutual enrichment and further development of research thought. As an illustration of these ideas, a study by Dan Goodbray (completed in 2017 and defended at the University of Hertfordshire) is of particular interest. Goodbray's research focuses on digital comics and seeks to understand how key characteristics of comics affect digital mediation. In the course of his research, the author studied digital page extensions and replacements, the hybridization of video games, problems of archi- tectural space, and the integration of time-based soundtracks into the comic book structure. Since Goodbray's work is a convergence of theory and practice, he created a series of prototypes and experimental works in both the physical and digita fields as part of his practical research. They can be seen at e-merl.com. Also, Dan Goodbray did a project for a "spatial comic", placing "frames" from the comic he created in an architectural environment. Based on this project, in his research, he shows that galleries that practice this approach (placing images from comics in a specific space) rely on approaches that initially appeared in digital formats to solve problems of architectural mediality. Goodbray's research allows us to refine our understanding of the comic book as a medium. An analysis of this and other cases suggests that a new view of practice as a scientifically significant activity is currently being established in Western academic circles. Since new knowledge is obtained or partially demonstrated "in practice", the proof of the practical significance of the obtained conceptual conclusions also occurs not only within the framework of theory but also in the space of practical research, which contributes to their verification.

Criteria for Assessing the Practical Significance

\section{of Projects: Preliminary Results}

In issues related to the institutionalization of practice-oriented postgraduate study programs, the effective criteria for evaluating the project itself are the most debated. It is partly due to the difference in approaches (academic theory tends more towards descriptive-analytical approaches and methods, whil practice - towards creative-activity, aimed at solving a specific problem). The combination of these approaches to actualize their effectiveness seem to be the most effective strategy. Thus, discussions about design thinking and design methodology in relation to science can be found in the works of many researchers. Robert McKim, an artist and enginee the author of the book Experiments in Visual Think ing (1973), is among the most interesting. Gerbe Simon formulated the very concept of "design think"ng" in his book The Sciences of the Artificial (1969) [2]. In his article "Design Ways to Know" [1], Nige Cross identifies the unique characteristics of design thinking finding it helpful to integrate it into the education system and the broader academic context. Finally, Brian Lawson did an in-depth study of the characteristics of design thinking and academic thinking. In empirical studies of three-dimensiona problem solving using two groups of students ("practitioners" and "scientists"), he found that "practitioners" used cognitive strategies focused on solving a problem ("synthesis"), and "scientists" used problem-oriented strategies ("analysis") [11]. The idea of combining both within the framework of a systematic approach is now being heard more and more of ten, and not only among designers/artists or in the academic environment but also in the field of business. For example, there is the DesignLondon Educational and Research Center (Great Britain), which combines three of the most influential schools in Britain in their field: the Design Department of the Royal College of Art, the Engineering Department at Imperial College and the Business Department from the Imperial College Business School. Among other significant projects in this area is the RED company (an initiative to transform the public sector and public services (Design Council, British Design Council); the goal is "the introduction of design innovations to improve the standard and quality of life", "the implementation of design in the social and economic sphere to address critical issues") [8], as well as the IDEO, international design consulting organisation. In addition to design projects related to society's problems and the economy, there are similar initiatives in art. For example, it is "social art" area, also associated with incorporating the artist into the social and economic sphere to transform it.

It seems logical that the project component of practice-oriented postgraduate project should be inscribed in the logic of the corresponding problem field, and educational institutions are obliged to present options for solving the problems posed. At the same time, the project component must exist within the framework of a strong theoretical structure of a high academic level. As one example of the existing "codification" of criteria for evaluating such studies, we can mention the joint PhD Arts program (the result of a collaboration between the Academy of Creative and Performative Arts of Leiden University and the Royal Academy of Arts in The Hague), which was discussed above. The program's website provides essential concepts, formulates criteria for evaluating practice-based research, and gives its definition: "Practice-based research applied to creative specialities is understood as research conducted in the field of artistic practices and design methods and with their application (for example, in areas such as visual arts, audiovisual art, design, interior design, mixed forms and interdisciplinary fields); at the same time, the practical activity and analyt ical work of the researcher are inextricably linked with the research topic, its process and results. an applicant is applying for a doctorate, they must demonstrate a high level of creative skill, originality and skills so that their research can be assessed as an important and innovative contribution to science, philosophy of art and creative practice" [13].

Similar "codifications" of requirements and criteria for evaluating the text component and project activities exist in all practice-oriented postgraduate programs. Differences can be in the number of experts involved in project evaluation, in the requirements for the volume of the text and for the documentation accompanying the project, etc. In 2006, Linda Candy made a presentation and wrote a guide article "Practice-Based Research: A Guide" $[6,7]$, in which she attempted to reflect the specifics of this issue; later, this "guide" was developed in her 2018 article "Practice-based Research in the Creative Arts: Foundations and Futures from the Fron Line" [5, pp.63-69], which she wrote with Ernest Edmondson. The article contains descriptions of a large number of "cases"; analysing one, Candy and Edmondson summarize: "The central results were embodied in artworks that facilitated and encouraged emergent thinking in members of the participating audience. It was necessary to demonstrate that this was, in fact, the case, and so, as well as delivering the research results in both text and documented artifact forms, the results of evaluations of participant responses were reported. Thus, the argumen that was claimed was supported by evidence gathered in a relatively conventional way. It is an example of practice-based research in which art making is central but in which evidence-based conclusions are provided." [5, pp.63-69].

Finally, the research evaluation and certification criteria at the Royal Danish Academy of Fine Arts $(\mathrm{KADK})^{2}$ serve as a valid "working model":

"Clarity: The criterion refers to the aesthetic aspect of the work. It is necessary to assess how the work is separated from the context and conditions of creation. In accordance with this criterion, the work's aesthetic effect and the artistic language chosen by the author (artistic level) are discussed.

Density: The criterion refers to the technical component of the work. It is essential to understand

Since the wording is periodically revised, the version on the in the text of this article. 
that the appearance of the work contains the effect and how the connection between the elements determines the intensity of the impact. This criterion evaluates how material properties, functions and concepts are combined in new contexts (technical level).

Depth: The criterion refers to the semantic component of the work. It is important to determine the depth of the relationship between the work and the formation of meaning in culture and society. According to this criterion, the work is compared to the class of works that have demonstrated the relevance of the topic development, and its contribution is discussed (contextual/theoretical level).

Expert judgment: a qualified practitioner + a qualified researcher in the given field" [17].

Thus, based on the analysis of the programs of practice-oriented postgraduate studies, the following can be distinguished among the main criteria for evaluating the practical component of the dissertation project:

- justification of the project's relevance (description of the boundaries of the problem field, problem statement, goal formulation; does the proposed project solve the problems posed or offer solutions to the problems posed?

- originality and novelty (the project must be original and not have complete analogues);

- presentation of the project; it is evaluated by n expert/experts (leading experts in the relevant problem area);

- knowledge of methodology, including design methodology (e. g., artistic research, practice as research, design methodology); it is evaluated by an expert/experts (leading experts in the relevant problem area):

- the presence of a qualified team implementing the project, the logic of phased planning, other conditions conducive to successful implementation the achieved results of implementation (for example, the presence of artifacts (works), the fact of an exhibition, performance, etc.);

- the social significance of the project (for ex ample, appreciation from the expert community, press reviews, etc.); an expert assessment of leading experts in this field is possible; the project's investment attractiveness can be taken into account

\section{Conclusion}

Now, there is a process of "rapprochement" between the academic community and the community of "practitioners" - artists and designers since on the one hand, scientists are interested in putting their developments into practice. On the other hand artists and designers need to differentiate and conceptualise their subject fields. It is because the processes in production, design, and partly in art began to change. There is a transition from creating artifacts/artifact corpus to designing intangible things it can be a service, strategy, "atmosphere", etc. This situation has led to the fact that new formats of the interaction of "theory and practice" began to appear in the space of academic educational programs. It can also be seen at the level of higher education we are talking about the format of practice-oriented postgraduate study ("PhD by Practice", "Art PhD" h" "practice-led research", etc). Within the framework of this article, we have made an attempt to reflect the specifics of this format, turned to the experience of foreign countrie where this format is gaining more and more popularity, raised the problems (primarily methodological) associated with the integration of this format into the space of academic knowledge, reflected the controversial nature of such a concept as "Practice as Research", and ways of developing this educational format. There is still an intense discussion on the status of "practice" as an educational format. It seems that today the search for new forms of interaction between the academic community and the community of "practitioners", and the "refinement" of existing formats is an urgent task, the solution of which will contribute to the development of socia and cultural initiatives and the formation of a creative community dominated by art. Summarising what has been said, it is safe to say that PhD-level postgraduate programs discussed at the Graduate School of Art and Design at the Higher Schoo of Economics are an alternative form of education during which students can not only expand theoretical knowledge, conduct interdisciplinary research but also represent project forms, demonstrating the skills and competencies acquired in the field of conpractical research, making it possible to update the approach to practice as research and incorporat methodological tools into representative forms of project approbation. Practice-oriented postgraduate programs for the Russian education system are an innovative format that requires understanding and choosing one's own educational strategy related to the specifics of multilevel and multidisciplinary education in Russia.

REFERENCES:

1. Cross, N. 1982. Designerly Ways of Knowing, [Online resource]. - URL: http://larossa.co/cross_1982 designerlywaysofknowing.pdf (date of access: 05.07.2021).

2. Simon, G. 1969. The Science of the Artificial, Moscow: Mir

3. "Art \& Education", PhD in Practice, Academy of Fine Arts Vienna [Online resource]. URL: https://www. artandeducation.net/announcements/109662/phd-inpractice-academy-of-fine-arts-vienna/ (date of access: 05.07.2021)

4. "Arts and Humanities Research Council" [Online resource].—URL: https://ahrc.ukri.org/ (date of access: 05.07.2021).

5. Candy, L., Edmonds, E. 2018. "Practice-based Research in the Creative Arts: Foundations and Futures from the Front Line", LEONARDO, vol. 51, no. 1

6. Candy, L. "Theory and Practice in Creative Practitione Research." Unpublished paper based on Keynote Talk to DESIRE2011 conference Eindhoven NL. [Online resource]. URL: https://www.academia.edu/10331703/ Theory_and_Practice_in_Creative_Practitioner

Research/ (date of access: 05.07.2021)

7. Candy, L. "Practice Based Research: A Guide." CCS Report: 2006-V1.0 November [Online resource]._URL https://www.researchgate.net/publication/257944497/ (date of access: 05.07.2021).

8. "Design Council" [Online resource]. - URL: https:// "www. designcouncilorg uk/ (date of access: 05.07 2021).

. Epstein, R. (2005). "Generativity Theory and Creativity", M. A. Runco \& R. S. Albert (Eds.), Theories of creativity (Rev. ed.). Cresskill, NJ: Hampton Press, 2005.
10. "Interview between the JAWS editorial team and D Rachel Hann", Journal of Arts Writing by Students, vol. 5, No. 1, 1 March 2019

11. Lawson, B. 2005. "How Designers Think - The Desig Process Demystified", University Press, Cambridge

12. PhDArts / Individual Projects / Resonances between Dance and Gnosis [Online resource].— URL: https:// www.phdarts.eu/ResonancesbetweenDanceandGnos is/ (date of access: 05.07.2021).

3. PhDArts, an international doctorate program in art and design, is a collaboration between Leiden University Academy of Creative and Performing Arts and the Royal Academy of Art (KABK) in The Hague [Online resource]._URL: https://www.phdarts.eu/Admission/ Requirements/ (date of access: 05.07.2021).

14. "Practice as Research in Performance: 2001-2006" [Online resource]._ URL: http://www.bristol.ac.uk/ parip/ (date of access: 05.07.2021).

15. Rust, C., Mottram J., Till, J. 2007. AHRC Research Review. Practice-Led Research in Art, Design and Architecture. [Online resource].— URL: http://www.ahrb.ac.uk/ research/grant/guide.htm / (date of access: 05.07.2021).

6. Research Pavilion \# 3 Venice 2019 [Online resource].URL: http://www.researchpavilion.fi/ (date of access: 05.07.2021).

17. The Royal Danish Academy of Fine Arts Schools of Architecture, Design and Conservation, Research and artistic research at KADK [Online resource].- URL: https://kadk.dk/en/research-and-artistic-researchkadk/ (date of access: 05 07.2021) 
Людмила Анатольевна Алябьева кандидат филологических наук, доцент Факультета коммуникаций, медиа и дизайна Ниу вшэ, Академический директор Аспирантской школы по искусству и дизайну e-mail: lalyabieva@hse.ru Москва, Россия

ORCID0000-0001-7795-2059

ResearcherID Z-1306-2019

Ирина Михайловна Сахно доктор филологических наук, профессор кафедры теории и истории культуры RUDN UNIVERSITY, Академический руководитель магистерской программы «Практики современного искусства» Факультета коммуникаций, медиа и дизайна, Школы дизайна НИУ вШэ e-mail:sakhno_im@pfur.ru Москва, Россия ORCID0000-0002-5510-6684 ResearcherID B-2047-2016 Scopus Author ID57196349789

Татьяна Евгеньева Фадеева кандидат искусствоведения, доцент Факультета коммуникаций, медиа и дизайна НИУ вШЭ e-mail: tfadeeva@hse.ru Москва, Россия ORCID0000-0002-6754-4235 ResearcherID Z-2521-2019

DOI: 10.36340/2071-6818-2021-17-4-91-109

\section{"PRACTICE AS RESEARCH": ИССЛЕДОВАТЕЛЬСКАЯ И ТВОРЧЕСКАЯ ПРАКТИКА В ФОРМАТЕ ПОСТДИПЛОМНОГО ОБУЧЕНИЯ}

Аннотация: В центре внимания авторов статьи дискуссионный формат практических исследований: "Practice as Research". В последние годы практика как исследо бар

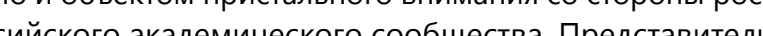
сийско о академическо о сообществ Представители разлиных дисциплин в области искусства и ууманиТарных наук убедительно доказывают необходимость подбного формата творческой практики в сфере перформанса, театра, танца и современного искусства. Практика как исследование включает в себя разные формы и способы репрезентации прикладных и проектных художественных продуктов. Фитура практикующег исследователя вызывает сегодня споры и дискуссии потому что модель творческой практики как метод из учения искусства - инновационный образовательный формат. Большие трудности вызывают и параметры оценки практического исследования, соотношение те- оретического, чисто исследовательского, и творческого материала. Живое обсуждение вызывает как методоогия основанна на практике таки собствено параметры оцени практики как исследования. Ситуацив препо

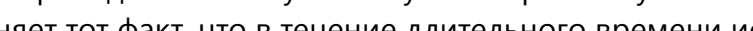
с солер

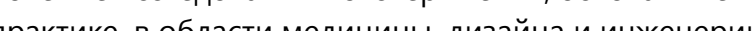

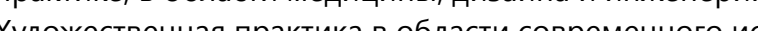
Художеская пракика в области современного искуссва и дизайна в последнее время стала объектом пристального внимания в Аспирантской школе по искуству и дизайну НИУ ВШЭ, потому что практический фокус визуальных исследований- основной трек сегодня в образовательных бакалаврских и магистерских программах. Новое понимание искусства как практики и одновременно исследования может пролить све на многие темы, включая культурную антропологию,

своей статье отстаиваем идею междисциплинарности подобных исследований. Художественная практика как область академических исследований и новый опыт постдипломного образования находится в центре наших исследовательских рефлексий. Мы стремимс обобщить опыт европейских образовательных программ, расширить диапазон методологических подходов и представить авторскую концепцию. Практика и исследование давно неразделимы во многих гуманитарных науках, проектные семинары и регрезентани творческих артефактов - суть образования в обаци современного искусства и дизайна. Современное российское образование только начинает осваивать ной територио, $n$ в этом синсле наше коллективно исследование иннованионного формата призвано проинализироват зарубежнй орыт и сформулировать необходимость продвижения новых образоватед

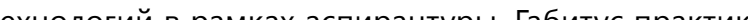

\section{Введение}

В системе европейского образования на факультетах искусства и гуманитарных наук ведутся споры и дискуссии о содержании зародившегося не так давно формата практических исследований. "Practice as Research" устраняет сложившуюся дихотомию между теорией и практикой в классическом образовании и предлагает совершенно новый для нашей страны образовательный формат. Сегодня факт влияния практики на научное исследование очевиден. Существует множество моделей исследования практики: практика как исследование; практика под руководством практика; практика, ориентированная на исследование. Сложность состоит в том, что объектом внимания является исследование проекта в области искусств, который становится самостоятельным элементом исследовательского процесса, оформленным при этом как художественная практика. Поэтому практика как исследование не является методологией, скорее, это новый инструментарий исследования художественно-проектной деятельности. Сам термин «практика как исследование» представляется нам достаточно размытым, и в академической среде позиционируется как широкий спектр деятельности без очерченных границ. Практика как исследование может включать в свой тезаурус множество характери стик: это и исследовательский процесс, результаты которого оформлены как художественная практика, это и практический результат исследования в формате арт-проекта, или это теорети ческое исследование достигнутых практических результатов. Такое расширенное толкование ху- как исследования таков, что в исследованиях, основанных на практике, ставится вопрос о формах критической деятельности и содержательных параметрах творческого артефакта, о документировании матери алов исследования. Поставленная исследовательская проблема в сочетании с практикой демонстрирует оригинальность исследования и расширяет границн исследовательского поля посредством введения гибридной методологии оценки творческого проекта и критиче ского дискурса. Задача авторов статьи - обозначит дискуссионное проблемное поле, проанализироват аналитические данные, связанные с инновачиовны научным полем и представить важные страты нового образов Ключевне cлова: "Practice as Research", nparmuky-

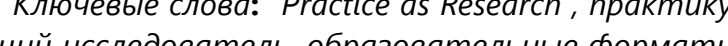
аспирантура, креати, образовательные формап

дожественной практики обозначает множество проблемных зон: где начинается и заканчивается собственно художественная практика, в каком соотношении находятся теоретические и практические результаты, с помощью какой методологии возможна подобная интеграция исследования и проектной деятельности? Ясно одно, что практические исследования, опираясь сегодня на различные творческие методы, могут быть включены в междисциплинарные творческие проекты, инновационные по своему содержанию. Без сомнения, подобный образовательный формат меняе наши представления о стратегиях репрезентаци современных знаний в области искусства и гуманитарных наук, расширяя пространство существующих знаний. Можно сказать, что практические исследования сегодня - являются мощным драй вером развития новой экономики знаний и составной частью креативных индустрий. Практика как исследование в современном искусстве озна чает не только апробацию научных результатов в формате художественного проекта, но и расширяет дискурсивное поле современных знаний в области искусств и гуманитарных наук. Это своеобразная форма культурной практики и ис следование широких контекстов: социально-политических и художественных. Это и производство новых видов интеллектуальных и культурных продуктов в сфере творческих индустрий.

Важно отметить открытый формат практических исследований. Это всегда дискуссионно поле для академических рефлексий и экспери ментальные жанры перформативных практик, инновационные репрезентации исследователь- 
ских проектов. Хорошо известен европейский опыт исследования перформанса во многих ведущих европейских университетах. Например, на сайте лаборатории PARIP Факультета драмы Бри стольского [13] университета можно ознакомиться с результатами практики как исследования и свя занной с ней критической деятельностью, увидеть внедрение эффективных систем цифровой документации для живого исполнения (танец, театр, драма) - архивирование материала практических исследований как важнейшей стратегии в проектно-исследовательской деятельности. Важнейшими параметрами оценки деятельности подобных лабораторий являются расширение диапазона разных форм практики как исследования, модификация привычных форм критической деятельности и расширение возможностей репозитория.

В июле 2020 года Совет по исследованиям в области искусств и гуманитарных наук Великобритании, цель которого - координация проектов в области науки и образования, разработал и опубликовал дорожную карту «Исследования и разработки», в которой изложено долгосрочное видение, направленное на раскрытие потенциала науки, исследований и инноваций. В будущей стратегии развития науки практические исследования в области искусств и гуманитарных наук занимают важное место и рассматриваются как креативный инструмент инновационных стратегий и дальнейшего взаимодействия науки и искусства [4]. Аспирантская школа по искусству и дизайну ВШЭ одна из первых обратилась к вопросу о необходимости создания подобного формата образования в российских вузах. Новая культура исследований сегодня как никогда востребована в формате инклюзивного национального подхода во всех странах. России предстоит осмыслить инновации в сфере образования и новые глобальные вызовы, в силу чего обсуждение практических и прикладных исследований кажется нам своевременным и актуальным.

Формат практических исследований

pro \& contra

Размышляя об интеграции подходов к аспирантской программе обучения, мы видим уникальную концентрацию образовательных платформ, которая сочетает парадигмы универсальных и профессиональных компетенций. Для того, чтобы определить российскую траекторию развития и прогнозировать конечные результаты инно- вационных образовательных технологий, нужно учитывать успешные реализуемые практики и опыт европейских стран, при этом исходить из целеполагания и направленности тракторий развития образования в России в новых условиях креативной экономики и экономики знаний. Общество инновационных информационных технологий продуцирует знания не только в экономике и бизнесе, но и в образовательной сфере. Формализованное образование - это тот накопленный в процессе обучения багаж знаний и опыта, который будет впоследствии востребован на рынке образовательных услуг. Генезис информацион ного общества неразрывно связан с новой экономикой знания, и, в частности, с включение современного образования в международный контекст. Сегодня знания непрерывно обновля ются, генерируются новые подходы и инновации возрастает роль научной и интеллектуальной де ятельности. В этом контексте особенное значение приобретают креативные компетенции как способность к творческому саморазвитию, генерированию инновационных идей и продуцированию новых подходов. Одним из первых исследовате лей, кто ввёл в научный оборот понятие «креативная компетентность», был Р. Эпстайн, который охарактеризовал этот феномен как форму адаптации к новым вызовам цивилизации и готовност человека к самостоятельному обучению, самораз витию и самосовершенствованию [9, р. 116-140] Безусловно, креативная компетентность сегодня в условиях новых вызовов, - это способност к производству новых творческих идей, которые будут востребованы в ближайшие десятилетия. Адаптивность и нестандартность мышления, инкорпорирование новых знаний в практические навыки и художественную деятельность, самостоятельность в принятии решений и способность к действию, реализация накопленного опыта это интегративность знаний и многофакторность задач, которые необходимы в оценке качества образования современных выпускников вузов.

В технологиях проектирования креативных компетенций важнейшую роль играет сегодня аспирантская ступень обучения. Возникает вполне правомерный вопрос, как совместить стандарть и индивидуальные научные платформы, как сделать образование в области искусства и дизайн конкурентоспособным? На наш взгляд, "Practice as Research" как форма академического иссле- дования исключает традиционную дихотомию между теорией и практикой. Сегодня в научном и академическом сообществе продолжаются споры о том, как корректнее определить зарождающийся феномен, какие привычные дефиниции (практика - практика, смешанная практика исследования, практика-исследование) сделать приоритетными. Все сходятся в одном: исследования В практико-ориентированных аспирантурах должны быть подчинены практическим целям. Может ли художественная практика быть признана исследовательской? Ведь любой проект имеет концептуальную основу, цели и задачи, актуальность и новизну. Все чаще зарубежные учёные и педагоги обращаются к такому понятию, как «практические исследования». Совет по исследованиям в области искусств и гуманитарных наук Великобритании опубликовал в 2007 году доклад, посвященный практическим исследованиям в области искусства, дизайна и архитектуры [15], что послужило основой для дискуссий по проблеме практики как исследования. Появившиеся дефиниции practice-based $и$ practice-led лишь усложнили методологию оценки практических исследований, потому что исследования, основанные на практике, и исследования, реализуемые на практике, трудно поддаются чёткой классификации. Несомненно, для нас более важным является то, что международным сообществом был признан факт необходимости исследовательской компоненты в практических проектах.

Л. Кэнди пытается аннулировать все противоречия, размышляя об «исследованиях на основе практики» и «исследованиях под руководством практиков», основным критерием которых должен стать параметр генерирования оригинальных идей [7]. В любом случае речь идёт об исследовательском проекте с разными форматами его реализации. Практика как неотъемлемая часть исследовательского процесса с документальным подтверждением и текстологическим анализом представляет сегодня новейший образовательный формат. Новые подходы и требования к квалификационным параметрам свидетельствуют о необходимости критических рефлексий и оригинальной научной идеи, что очень важно для любой методологии научного исследования. В формате практических исследований в рамках докторской степени, по мысли Л. Кэнди, обязательна «контекстуализация творческой работы» [7], степень её оригинальности и вклад учёного в научный ландшафт предметной области. Совер шенно очевидно, что пространство «практических исследований» невозможно строго обозначить, тем более, если мы имеем дело с прикладным феноменом дизайна или исследовательским полем современного искусства.

Практика как исследование, или практические исследования,-это актуальное поле професси ональных дискуссий сегодня в образовательных и научных дискурсах. Мы имеем дело с различными блоками теоретических и практических знаний, с разными параметрами оценки уровней и видов практик, и разрыв в формулировках и отсутствие единого подхода очевидны. Нельзя не согласитьта Сюррея Рейчел Ханн, которая говорит о том что пришло время унифицировать все подходы к определению «практических исследований $[10$, р. 5], и что сама формула «практик-исследо ватель» - это всего лишь временная мера. Великобритания стояла у истоков системы оценки эффективности достижений в области практических исследований. Эта шкала дифференциаций Research Excellence Framework (REF) - является важнейшей характеристикой признания эффективности лекторов и результатов исследования. Именно рейтинг школ и факультетов определяет уровень финансирования проектов. Сегодня совершенно очевидным становится тот факт, что практические исследования расширяют своё пространство, и мы можем говорить не только о легитимизации практики художников, но и о боле широких интегративных компетенциях в разных областях современного искусства. Практические исследования становятся полифункциональными они затрагивают многие междисциплинарные исследовательские поля. Практические исследования сегодня демонстрируют свою жизнеспособность, и всё же остаются «petra scandali» дл академической оценки и рамочной документации

Остаётся дискуссионным вопрос о формах репрезентации и способах артикуляции результатов проекта и его исследовательской матриць. В каком формате может быть представлен методологический фокус? В какой форме должно быть организовано хранилище объектов исследования (документация, изображения, видеоформаты, междисциплинарные репрезентации и т.д.) с использованием цифровых платформ и университетских сайтов? Насколько необходим репозиторий проекта? Важной составляю- 
щей практического исследования, на наш взгляд, является не только демонстрация всех достигнутых результатов, но и возможность поделиться ими с неакадемической аудиторией. «Практи кующий исследователь» - новый формат для современного академического образования, и потому предвзятость к этой форме самопозиционирования художников и дизайнеров очевидна и часто подвергается критике Сегодня кажется вероятным, что между «академическим исследованием» и «практическим исследованием» будет проведена граница, ибо метод и инструментарий исследования существенно отличаются. Трудно смириться нашему академическому сообществу С тем, что «практикуощий исследователье- Тоже учёный. При этом, на наш взгляд, не стоит изобретать новые методы и способы артикуляции основного содержания проекта, исследовательские эксперименты должны быть понятны не только академической, но и неэкспертной аудитории. В пользу этого вывода говорит практика и результаты первой волны практических исследований несмотря на возникший спор об исследовательской экологии.

Ещё одна несомненно важная проблема - это документирование и архивирование практических исследований, воплощение основных результатов практического проекта в научных статьях и монографиях. От этого зависит будущее этого инновационного научного формата. Практические исследования сегодня требуют от нас переосмысления не только научной методологии но и расширения пространства альтернативных образовательных платформ и новых дискурсивных практик. Важным параметром становится собственный практический и исследовательский опыт художника и дизайнера. То же самое можно сказать и о факультетах исполнительских искусств. Сегодня в Европе и США активно обсуждается вопрос об институциональном статусе практи ческих исследований и их включении в государственные программы финансирования. Очевидно, что новейшие практики в современном искусстве и дизайне могут быть маркированы только в контексте практики как исследования и репрезентативной модели апробации научных результатов. Преодолеть разрыв между фундаментальными и практическими исследованиями в области искусства и дизайна - задача непростая и требуе системного мышления и определённой смелости и в этом смысле новые форматы аспирантуры, включая PhD by Practice, кажутся нам наиболее перспективными

Стратегии репрезентации практико-ориентированных аспирантских программ в европейских вузах

Возвращаясь к вопросу о различных формах и стратегиях репрезентации практико-ориенти рованных аспирантских программ, необходи мо отметить, что многие из них существуют уже не первый год. Например, программа «PhD in Practice» [3] Венской академии искусств (Academy of Fine Arts, Vienna), одной из ведущих инсти туций в сфере искусства и дизайна, существует 10 лет (с 2010 года) и уже успела зарекомендотальной «лаборатории», гибко реагирующей на запросы и креативных индустрий, и академий В описании программы говорится, что современные художественные практики зачастую ос нованы на критических эпистемологиях, так как они были разработаны в соответствии с гендерными исследованиями, феминистскими, постмарксистскими и постколониальными теориям и т.д. Подчёркивается социальная роль современного искусства и художников, которые занимаются исследованиями этих тем. Акцент делается на эпистемологических и методологических основах и перспективах современного искусства, особый интерес для разработчиков программы представляет вопрос о том, как художественные практики связаны с важными вопросами современной политики и культуры, а также с бизнесом. В связи с этим можно упомянуть состоявшуюс в 2017 году в Венеции выставку участников программы «PhD in Practice» «HAUNTOPIA / WHAT IF», посвящённую «призракам» - Т. е. событиям, знакам, образам, практикам и предметам, которые рассказывают о прошлом и «продуцируют рефлексию о возможном будущем. Кроме этого перспективными представляются «коллаборационные» проекты - такие как, например, программа «PhDArts», которая является результатом сотрудничества между Академией креативных и перформативных искусств Лейденского универ ситета и Королевской академией искусств в Гааг [13]. Представляется, что подобные совместные проекты позволят более эффективно использовать ресурсную базу университетов-участников На странице «Индивидуальные проекты» сай та программы «PhDArts» фигурируют любопыт ные исследовательские инициативы, такие как например, проект C. Тунка «Resonances between Dance and Gnosis» [12]

Большой интерес также представляет Аспирантская школа Ниды, Литва (The Nida Doctora School (NDS), реализующая интенсивную программу для соискателей DA и PhD в области изобрази тельного и перформативного искусства, дизайна, медиа и архитектуры, а также гуманитарных наук. Программа предполагает тесное сотрудничество с выдающимися практиками в соответствующих областях, доклады, дискуссионные группы, презентации докторских исследований (формальные, неформальные, перформативные, экспериментальные и т.д.), рецензирование, групповые и индивидуальные консультации. В 2019 году инициативы NDS проходят на площадках Венецианской биеннале - в Литовском и Исследовательском павильонах [16] и др. Чрезвычайный интерес представляет сам формат исследовательского павильона. Здесь мы наблюдаем «встречное» движение - из академии в мир искусства. Исследовательский павильон - это международный проект, организованный Uniarts Helsink при поддержке the Louise and Göran Ehrnrooth Foundation, а также Aalto University, Valand Academy of Arts at the University of Gothenburg University of Applied Arts Vienna $\boldsymbol{n}$ Interlab Hongik University Seoul. В рамках этого павильона, существующего уже шесть лет (это возобновляемый проект, который уже в третий раз реализуется на Венецианской биеннале), акцент делается на художественном исследовании (artistic research). Цель проекта - привлечь художников и исследователей со всего мира на площадки павильона который мыслится катализатором налаживания сотрудничества в области художественных исследований и генератором «нового мышления» (новой логики взаимодействия художника и академии). Например, нынешний Исследовательский павильон (Исследовательский павильон № 3 ) имеет модульную структуру, состоящую из шести исследовательских ячеек - пространств для параллельных процессов экспонирования, проведения, демонстрации и обсуждения исследований. Один из этих «модулей» носит название «Shelters» ${ }^{1}$ («приюты», «убежища») и посвящён

Проект основан на исследованиях, которые проводились в течение последних трех лет совместно с Исследователь-

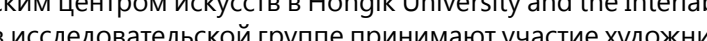
ки, кураторы, архитекторы, инженеры и философы вопросам функционально-ориентированного го родского планирования.

Не отказываясь от специфики «традицион ной» аспирантуры (написание диссертационного исследования), западные аспирантские школ по искусству и дизайну стремятся дополнить ее естественным для креативных индустрий элементом - проектно-практической деятельностью, так называемой «практикой». Таким образом, концептуально важные, весомые выводы и решения обычно имеющие социальное значение, оформляются в конкретные проекты с учётом контекста социоматериального мира и трансформирую этот контекст (в чём выражается практическая значимость диссертационного исследования).

В России же формат практико-ориентированной аспирантуры практически неизвестен, нет ни одной отечественной аспирантской школы по искусству и дизайну, где бы он реализовывался, нет осмысления этого вида исследовательской деятельности в специальной научной литературе. Отечественное образование в данной сфере на сегодняшний день по-прежнему сфокусировано в основном на пролонгации традиционной академической парадигмы. Многие художественные вузы (например, Московский государственный академический художественный институ им. В. И. Сурикова при Российской академии ху дожеств, Санкт-Петербургский государственный академический институт живописи, скульптурь и архитектуры им. И. Е. Репина при Российской академии художеств, факультет искусств МГУ им. М.В.Ломоносова и др.) готовят специалистов ориентированных на работу в рамках академического искусства, и недостаточно внимания уделяют актуальным художественным практикам спецификой которых (в свете модернистских и постмодернистских трансформаций искусства) является осмысление условий производства искусства, а также широкий круг вопросов, связанных с экономическим, политическим и культурным развитем современного общества.

13 декабря 2019 года в Школе дизайна прошёл второй круглый стол, посвящённый проблемам современного образования в области искусства и дизайна в России и в мире. Это была вторая встреча в серии дискуссий, инициированных Аспирантской школой по искусству и дизайну НИУ ВШЭ. В рамках данного круглого стола коллеги из-за рубежа делились собственным опытом. В частности, Эльзе Скьолд, доцент кафедры 
дизайна и устойчивого развития Датской королевской академии искусств (Копенгаген, Дания) представила успешные проекты исследований, реализованные в формате PhD by Practice в Королевской академии изящных искусств Дании (KADK). Среди представленных «кейсов» большой интерес вызывает PhD-исследование Карен Мари Хаслинг (DSKD) «Обучение через материалы. Развитие преподавания материаловедения в области дизайнерского образования» (2015), в котором автор предпринимает попытку ответить на вопрос о том, как может обновлённое понимание материалов в дизайнерском образовании помочь студентам сформировать навык обоснованного выбора материалов, под

Также в рамках круглого стола были озвучень новые образовательные технологии в выступлении Барбары Брауни (Хартфордширский университет, Великобритания), поделившейся опытом успешной реализации подобного рода «симбиотических» проектов, в которых практика и теория способствуют взаимообогащению и дальнейшему развитию исследовательской мысли. В качестве иллюстрации этих идей особый интерес представляет исследование Дэна Гудбрея (диссертация завершена в 2017 году и защищена в Университете Хартфордшира). Исследование Гудбрея посвящено цифровым комиксам и направлено на то, чтобы понять, как ключевые характеристики комиксов влияют на цифровую медиацию. В ходе исследования автор изучал цифровые расширения и замены страницы, гибридизацию видеоигр, проблемы архитектурного пространства и интеграцию в структуру комиксов звуковых, основанных на времени, саундтреков. Так как работа Гудбрея представляет собой конвергенцию теории и практики, то в рамках своих практических исследований он создал серию прототипов и экспериментальных рабо как в физической, так и в цифровой областях. Их можно увидеть на сайте e-merl.com. Также Дэн Гудбрей сделал проект «пространственного комикса», разместив «кадры» из созданного им комикса в архитектурной среде. На основании этого проекта в своём исследовании он показывает, что галереи, практикующие подобный подход (размещение изображений из комикса в конкретном пространстве), опираются на подходы, первоначально появившиеся в цифровых форматах для решения проблем архитектурной медиальности. Исследование Гудбрея позволяет нам уточнит наше понимание комикса как медиума. Анализ этого и других кейсов позволяет утверждать, что в настоящее время в западных академических крувах утверждается новый взгляд на практику как научно значимую деятельность. Так как новое знание получено или частично продемонстрировано «на практике», то и доказательство практической значимости полученных концептуальных выводов также происходит не только в рамках теории, но и в пространстве практических исследований, что способствует их верификации.

\section{Критерии оценки практической значимо}

\section{и проектов: предварительные результаты}

В вопросах, связанных с институционализацией программ практико-ориентированной аспирантуры, наибольшую дискуссию вызывают эффективные критерии оценки собственно проектной части. Отчасти это происходит из-за несовпадения подходов (академическая теория больше склоняется к ОПисательно-аналитическим подходам и методам, тогда как практика - к креативно-деятельностным, нацеленным на решение конкретной проблемы). Наиболее эффективной стратегией представляется совмещение данных подходов с целью актуализации их эффективности. Так, рассуждения о дизайн-мышлении и дизайн-методологии применительно к сфере науки можно найти в трудах многих исследователей. Среди наиболее интересных необходимо назвать Роберта МакКима, художника и инженера, автора книги «Опыты визуального мышления» (1973). Саму концепцию «дизайн-мышления» сформулировал Гербер Саймон в своей книге «Науки об искусственном» (1969) [2]. Найджел Кросс в стать «Дизайнерские способы знать» [1] выявляет уникальные характеристики дизайн-мышления, находя полезным его интеграцию не только в систему образования, но и в более широкий академический контекст. Наконец, глубоким изучением характеристик дизайн-мышления и академического мышления занимался Брайан Лоусон. В эмпирических исследованиях трёхмерного решения проблем, проходивших с использованием двух групп студентов («практики» и «учёные») он обнаружил, что «практики» использовали когнитивные стратегии ориентированные на решение проблемы («синтез»), а «ученые» использовали проблемно-ориентированные стратегии («анализ») [11]. Идея объединить и то и другое в рамках системного подхода на сегодняшний момент звучит всё чаще причём не только в среде дизайнеров/художни- ков или в академической среде, но и в области бизнеса. Например, существует образовательно-исследовательский центр DesignLondon (Великобритания), объединивший в себе три наиболее влиятельные в своей области школы в Британии дизайн-отделение Royal College of Art, инженерный факультет Imperial College $и$ бизнес-направление из Imperial College Business School. Среди других значимых проектов в данной области Компания «RED» (иничиатива по трансформации публичного сектора и сферы государственных услуг (Design Council, Британский Совет по Дизайну; цель - «внедрение дизайн-инноваций с целью повышения уровня и качества жизни», «внедрение дизайна в социальную и экономическую сферу для решения критических вопросов» [8], а также международная консалтинговая организация в области дизайна «IDEO». Кроме этого, помимо дизайн-проектов, связанных с проблемами общества и экономики, существуют аналогичные инициативы в сфере искусства, например, область «социального искусства», также связанные с инкорпорированием художника в социальную и экономическую сферу с целью её трансформации.

Представляется логичным что проектная составляющая практико-ориентированного аспирантского проекта должна быть вписана в логику соответствующего проблемного поля, и образовательные институции обязаны представить вари анты решения поставленных проблем. При этом проектная составляющая должна существ в рамках крепкой теоретической структуры высокого академического уровня. В качестве одного из примеров существующей «кодификации» критериев оценивания подобных исследований можно рпомянуть совместную аспирантскую програм мy PhDArts (результат коллаборации Академии креативных и перформативных искусств Лейденского университета и Королевской академией искусств в Гааге), о которой речь шла выше. На сайте программы приведены основные понятия, сформулированы критерии оценивания исследования, основанного на практике (practice-based research), а также дано его определение: «Исследование, основанное на практике, применительно к творческим специальностям понимается как исследование, проводимое в области художественных практик и методов дизайна и с их применением (например, в таких направлениях, как изобразительное искусство, аудиовизуальное искусство, дизайн, дизайн интерьера, смешанные формы и междисциплинарные области); при этом практическая деятельность и аналитическая работа самого исследователя неразрывно связан с темой исследования, его процессом и результатами. Если соискатель претендует на докторскую степень, он должен продемонстрироват высокий уровень творческого мастерства, ори гинальность и навыки, чтобы его исследование можно было оценить как важный и новаторский вклад в науку, философию искусства и творческую практику» [13].

Подобные «кодификации» требований и критериев оценивания текстовой составляющей и проектной деятельности существуют в рамках всех программ практико-ориентированных аспирантур. Различия могут быть в числе экспертов, привлекаемых для оценки проекта, в требования к объёму текста, к документации, сопровождающей проект и пр. В 2006 году Линда Кэнди выступила с докладом и написала статью-гайд «Practice Based Research: A Guide» [6, 7], в которой предприняла попытку отразить специфику данного вопроса; в дальнейшем этот «гайд» получил развитие в её статье 2018 года «Practice-based research in the creative arts: Foundations and Futures from the Front Line» [5, p. 63-69], которую она написала совместно с Эрнестом Эдмондсоном. В статье даны описания большого количества «кейсов»; анали зируя один из них, Кэнди и Эдмондсон резюмируют: «Ключевые результаты нашли отражение в произведениях искусства, которые способствовали формированию у вовлечённых в процес зрителей новых идей. Необходимо было проде монстрировать, что перед нами конкретный кейс поэтому были представлены не только результаты исследования в письменном виде и в форме различных артефактов, документирующих его процесс, но и общая картина реакций участни ков. Поэтому удалось достаточно традиционным способом показать обоснованность выдвинутого тезиса. Это пример исследования, основанного на практике; главное в нём - творческая составляющая, но в то же время приведены выводы подкреплённые доказательствами» [5, р. 63-69].

Наконец, в качестве действующей «рабочей модели» выступают критерии оценки и аттестации исследований в Королевской академии изящных искусств Дании (KADK) 2 :

Так как формулировки периодически дорабатываются версия на сайте может не во всём совпада
представленной в тексте настоящей статьи. 
«Ясность: Критерий относится к эстетической составляющей работы. Необходимо, чтобы был возможность оценить, насколько чётко работа отделена от контекста и условий создания. В соответствии с этим критерием обсуждается эстетический эффект работы и выбранный автором художественный язык (художественный уровень),

Интенсивность: Критерий относится к технической составляющей работы. Важно понять, что во внешнем виде произведения содержится эффект, и каким образом связь между элементами определяет интенсивность воздействия. В соответствии с этим критерием оценивается то, как свойства материала, его функции и концепции сочетаются в новых контекстах (технический уровень).

Глубина: Критерий относится к смысловой составляющей работы. Важно определить глубину отношения произведения к смыслообразованию в культуре и обществе. В соответствии с этим критерием работа соотносится с классом работ, которые продемонстрировали актуальность развития темы, и обсуждается её вклад (контекстуальный / теоретический уровень).

Экспертная оценка: квалифицированный практик + квалифицированный исследователь в данной области» [17].

Таким образом, на основании анализа программ практико-ориентированных аспирантур среди основных критериев оценивания практической составляющей диссертационного проекта можно выделить следующие:

- обоснование актуальности проекта (описание границ проблемного поля, постановка проблемы, формулировка цели; предложенный проек решает поставленные проблемы или предлагает варианты решений поставленных проблем?)

- оригинальность и новизна (проект должен быть оригинальным и не иметь полных аналогов),

- презентация проекта; оценивает эксперт/ эксперты (ведущие специалисты в соответствующей проблемной области);

- владение методологией, в том числе проектной (напр., artistic research, practice as research дизайн-методология); оценивает эксперт/эксперть (ведущие специалисты в соответствующей проблемной области);

- наличие квалифицированной команды, ре ализующей проект, логики поэтапного планирования, иных условий, способствующих успешной реализации, достигнутые результаты реализации (например, наличие артефактов (произведений) факт состоявшейся выставки, перформанса и пр,

- социальная значимость проекта (например, наличие высокой оценки со стороны экспертного сообщества, отзывов в прессе и др.); возможна экспертная оценка ведущих специалистов в данной области; может учитываться инвестиционная привлекательность проекта.

\section{Заключение}

В настоящий момент наблюдается процесс “сближения» академического сообщества и сообщества «практиков» - художников и дизайнеров, поскольку, с одной стороны, учёные заинтересованы во внедрении своих разработок в практику, а с другой стороны, художники и дизайнеры нуждаются в дифференциации и концептуализа ции своего предметного поля. Это связано с тем, что процессы в производстве, дизайне, отчасти и в искусстве стали меняться, происходит переход от создания артефактов / корпуса артефактов к проектированию неосязаемых вещей-это может быть услуга, сервис, стратегия, «атмосфера» и т.д. Подобная ситуация привела к тому, что в пространстве академических образовательных программ начали появляться новые форматы взаимодействия «теории и практики», причём и на уровне высшей школы - речь идёт о формате практико-ориентированной аспирантуры («PhD by Practice», «Art PhD», «practice-based research», «practice-led research» и т.д.). В рамках данной статьи мы предприняли попытку отразить специфику данного формата, обратились к опыту зарубежных стран, где данный формат набирает всё большую популярность, затронули проблемы (прежде всео методологические), связанные с интеграцией данного формата в пространство академических знаний, отрефлексировали дискуссионность такого понятия, как "Practice as Research", и пути разви тия этого образовательного формата. До сих пор идёт интенсивная дискуссия относительно статуса «практики» как образовательного формата. Представляется, что на сегодняшний день поиск новых форм взаимодействия академического сообще ства и сообщества «практиков», и «доработка» уже существующих форматов является актуальной задачей, решение которой будет способствовать развитию социально-культурных инициатив и формированию креативного сообщества с доминантой художественного делания. Обобщая сказанное, можно с уверенностью сказать, что аспирантские программы уровня PhD, обсуждаемые в Аспирантской школе по искусству и дизайну НИУ ВШЭ, являются альтернативной формой обучения, в процессе которого обучающиеся могут не только расширить теоретические знания проводить междисциплинарные исследования, но и репрезентировать проектные формы, демонстрируя навыки и компетенции полученные в сфере современного дизайна и искусства. Важной составляющей являются и практические ис

БИБЛИОГРАФИЯ

1. Кросс Н. Дизайнерские способы знать 10. Interview between the JAWS editorial team and D («Designerly ways of knowing»). - 1982 [Сетевой ресурc]. - URL: http://larossa.co/cross_1982 designerlywaysofknowing.pdf / (дата обращения: 05.07.2021).

2. Саймон Г. Науки об искусственном.- М.: Мир, 1969 Art \& Education / PhD in Practice, Academy of Fin Arts Vienna [Cетевой pecypc].- URL. https://www. artandeducationnet/an pecypcl.practice-academy-of-fine-arts-vienna/ (дата обраще-
ния: 05.07.2021).

4. Arts and Hymanities Reseach Concil [Сетевой peArts and Hymanities Reseach Concil Сетевой pe-
cypc].—URL: https://ahrc.ukri.org/ (дата обращения: cypc].—URL:

5. Candy L., Edmonds E. Practice-based research in the creative arts: Foundations and Futures from the Fron Line // LEONARDO. - Vol. 51.- No. 1. - 2018

6. Candy L. Theory and Practice in Creative Practitioner Research. Unpublished paper based on Keynote Talk to DESIRE2011 conference Eindhoven NL. [Сетевой pecypc]. - URL: https://www.academia.edu/10331703/ Theory_and_Practice_in_Creative_Practitione Research/ (дата обращения: 05.07.2021).

7. Candy L. Practice Based Research: A Guide. CCS Report: 2006-V1.0 November [Сетевой ресурс].-URL: https://www.researchgate.net/publication/257944497/ (дата обращения: 05.07.2021)

8. Design Council [Online]. - URL: https://www. designcouncil.org.uk/ (дата обращения: 05.07.2021).

. Epstein R. (2005). Generativity theory and creativity. In M. A. Runco \& R. S. Albert (Eds.), Theories of creativity (Rev. ed.). Cresskill, NJ: Hampton Press, 2005. следования, которые позволят актуализировать подход к практике как исследованию и инкорпорировать методологический инструментарий в репрезентативные формы апробации проектов. Практико-ориентированные аспирантские программы для российской системы образоватребующий осмысления и выбора собственной образовательной стратегии связанной со спецификой многоуровнего и многопрофильного об разования в России. ния представляют собой инновационный формат 
ORCID 0000-0002-5355-8565

Daria E. Kardashenko Lecture

Stroganov Moscow State Academy of Design and Applied Arts e-mail: dkardashenko@gmail.com Moscow, Russia

ORCID 0000-0001-5707-5319

DOI: 10.36340/2071-6818-2021-17-4-110-123

\section{ARTISTIC POTENTIAL OF DIGITAL GRAPHICS MODELLING. CONVERGENCE OF TRADITIONAL AND MULTIMEDIA EXHIBITION MEANS FOR DISPLAY OF DIGITAL ARTWORKS}

Summary: The article considers the artistic potential of computer graphic modeling on the example of modern exhibition events that implement the convergence of traditional and multimedia exhibition facilities in the demonstration of digital art. Modern trends in multimedia transformation of exhibition spaces are outlined. The study resulted in recommendations for the optimal organ-

\section{Introduction}

The main goal of this study is to analyze the impact of modern digital graphic modeling capabilities on the process of art creation. The research area is an overview of the current state of digital graphic art, its artistic potential, the main available means of expression as well as an analysis of the prospects for displaying works of digital art in an environment that combines traditional and multimedia exhibition facilities.

1.1. The value of the digital graphical simu-

\section{lation in contemporary art.}

Born in the 60 s of the $X X$ century, compute graphics has gone a long way from early experiments for scientific and technical needs and individual special effects in large-budget films in the ization of the environment for displaying hybrid as well as digital works of art. The conclusions on the prospects for the development of innovative exhibition spaces will allow to optimize the functioning of the exhibition environment with a growing share of digital graphic content. Key words: digital arts, multimedia exhibition, VR/A applications in GLAM, gamification in arts expositions.

$70 \mathrm{~s}$ and $80 \mathrm{~s}$ to a strong position in various forms of art in the 90s. The modern era demonstrates the total dominance of digital technologies in the mass market of artistic content. This is due both to the huge variety of artistic expression tools provided by modern graphic modeling tools and to the high of the digital environment. This process is influenced by the factor of flexible integration of various types of content and the convenience of interaction between individual artists. Together, this gives a transition to a new level of artistic expression, while radically increasing the number of works created annually in the world. A significant reduction in the cost caused by the introduction of digital modeling allows moderate-sized teams to implement animation and cinematic projects that were previously created by large teams, at great expense and for a long time. Similarly, small teams and even single designers equipped with a rich arsenal of software and hardware can cope with the volume of architectural and environmental creativity unavailable in the classical era.

1.2. The current trend of convergence of traditional and multimedia display.

The explosive growth in the penetration of digital graphic technologies in the process of creating artistic works dictates the need to create new kind of exhibition spaces. In many cases digital technologies do not replace traditional art works and do not create specialized digital exhibition spaces but rather converge traditional and digital art in a single exhibition environment. This allows one to significantly expand the target audience, diversify the impressions received by visitors and get a positive response from visitors to the exhibition that contributes to the commercial success of exhibitions and increase the public importance of graphic art.

2 Areas of application of digital tools for graphic arts.

\section{.}

The first computer games began to appear as experiments of computer enthusiasts soon after the first computers appeared. Graphic capabilities and availability of computers grew rapidly: in the 70-80 years widely available gaming systems with two-dimensional graphics began to appear that were followed in 90 's by three-dimensional game graphics. At the turn of the century the use of hardware acceleration capabilities for three-dimensional graphics became mainstream. most gaming systems received a specialized computer-a graphics processor with hardware acceleration capabilities for rendering polygonal graphics in real time. In the first decade of the twenty-first century video cards first gained the ability to speed up shading and by the end of the decade turned to high-performance multithreaded computers for general-purpose tasks. In relation to the tasks of digital art such an increase in available computing power has led to the following main trends:

- The graphic design of three-dimensional computer games is rapidly becoming more complex, the applied models are moving in the direction of cinematic complexity and the quality of the resulting image gradually tends to photorealistic.

- Software systems for implementing the game environment become a powerful tool for creating three-dimensional interactive art objects. Just as in the case of graphics processors: mass production contributes to the low cost of hardware and the mass market for game software contributes to th availability of complex game development tools for use even in single art objects.

- The introduction of artificial intelligence elements in interactive exhibition objects allows on to transform exhibition spaces, making the user's participation in the system as simple as possible allowing one to involve a visitor to a traditiona museum in a virtual environment without anyone's assistance. Modern means of data input into a com puter which are the development of modern gaming input devices allow one to capture the user's movement, face recognition and other body parts The real-time processing can be resulted either as static two-dimensional images or three-dimensional animation with the user's participation.

- An important role in the exhibition spaces of popular science such as technical and natura science museums is played by systems (similar to computer games) for interactive visual simulation of required natural phenomena and technical objects.

Modern museums are able to create with moderate costs simulators that give the visitor a new leve of experience compared to traditional static exhibits. This allows one to effectively engage the modern mass visitor that is used to the abundance of available audio-visual content. This is especially important for exhibition spaces aimed at children and youth audiences. On the other hand, the hardware and software unification of an interactive simulator with three - dimensional game systems provides unique opportunities for creating accessible remote interactive simulation systems. The current state of affairs in this area is radically different from the situation of 30-40 years ago. Then computer three-dimensional graphics and interactive simulators created on its basis required the use of ex pensive graphic stations and could be used either only in the place of their installation (usually in industry, being unavailable for wide exhibition us due to the high cost), or serve as tools for the production of replicated visual works without interactive use. Quite contrary, modern systems based on mass commercially available components are being actively implemented. For example Wargaming company together with representatives of the Ministry of defense of the Russian Federation place an interactive multi-touch panel in the Central Mu- 
seum of the armed forces of the Russian Federation in Moscow in 2016 where historically accurate $3 \mathrm{D}$ models of more than fifty warships of the main classes of the five superpowers of the world wars of the $\mathrm{XX}$ century are presented in detail. Visitors were given the opportunity to get acquainted with 3D models each of which could be viewed in detail from any angle and from any angle, turning them from side to side, zooming in and out on the touch screen. All models were accompanied by historical references and tactical and technical characteristics. [4] It should be noted that this exhibition too repeats a part of the functionality of a commercia Wargaming product - an online game "World of Warships", a simulator of naval battles, and creating such an interactive stand is very cost-effective in comparison with the autonomous development of an exhibition stand since both the ready-made game engine and the graphic content already available in the game are used.

- At the intersection of computer games and industrial computer graphics, virtual and augmented reality systems have emerged and developed rapidly. As with mass-market gaming systems themselves, the reduced cost of switching to mass production made virtual reality tools available to a wide audience and combined stationary Museum complexes of $V R$ and $A R$ art displays with remote technologies based on well-established and popular standards of mass-market gaming systems. Russian State Museum of Fine Arts named after A. S. Pushkin introduced the Artefact AR application, free to download on the App Store and Google Play. Pointing the camera of a mobile device to an exhibit marked with a sign one can view all the information directly on the screen of the device - to find out historical facts about it or, for example, compare how the work looked before restoration and in the process of restoration work. [4]

Fig. 1.

The Department of environmental design and multimedia design in Moscow State Stroganov Academy of Design and Applied Arts named after S. G. Stroganov in the framework of the training programs "Game design", "Motion design", "Design", "Development interfaces", "Animation" actively seeks to appeal to modern trends to create a virtual exhibition space available in the form of Internet sites, design augmented reality app enabling digital transformation of the existing natural, industrial or urban environment, exhibition and educational needs, and also to give wide multimedia functionality of traditional exhibition environments - exhibitions, museums, sightseeing programs, modernizing the existing art formations under modern conditions through media reconstruction.

The diagram in Fig. 2.

- The formation of the mass gaming industry and its strong cultural integration gave rise to such a new social phenomenon in the organization of various social processes as gamification. The essence of gamification is the application of game elements and mechanics outside of the actual game process. Gamification allows one to effectively motivate people based on natural needs for the element of excitement, getting a regular flow of evaluated achievements and similar sources of emotions that avoid obvious pressure and other negatively perceived mechanisms.

Gamification is being implemented with great success in various branches of human activity. In relation to the popularization and educational function of museums gamification allows one to replace surveys and other formal methods of testing the perception of the studied material with a game in which the tested visitor is interested in demonstrating the knowledge obtained. In the case of prolonged immersion by installing an application with gamification elements on a personal smartphone the consumer will be motivated to visit and study of a vide number of exhibition spaces.

2.2. Art installations using graphic digital modeling

Computer technologies often perform not only secondary technical functions for displaying works of traditional art or bringing interactivity to the exhibition environment but can also take place as self-valuable art objects. The number of artists who prefer to use only a virtual environment in their work is increasing with each new year. One example is the American artist Andrew "Android" Jones who calls his exclusively digital works "mirror purgatory" and calls the main goal of his work to change the perception of reality and the immersion of human consciousness in virtual reality.

If the creative research of Android Jones lies mainly in the plane of 2D graphics, the work of the President of the Creative Union of artists Konstantin Khudyakov who is called the "pioneer of Russian digital sculpture" is based on working with three-dimensional graphics. "He replaced marble and chise with 3D Studio Max, AutoCad, and 3D printer" [5]

Цифровое

искусство

Традиционные художественные материалы

Механика электрика, электронные компоненть

\section{ифровой контент \\ Мультимедиа \\ Инфраструктура}

связи и хранения

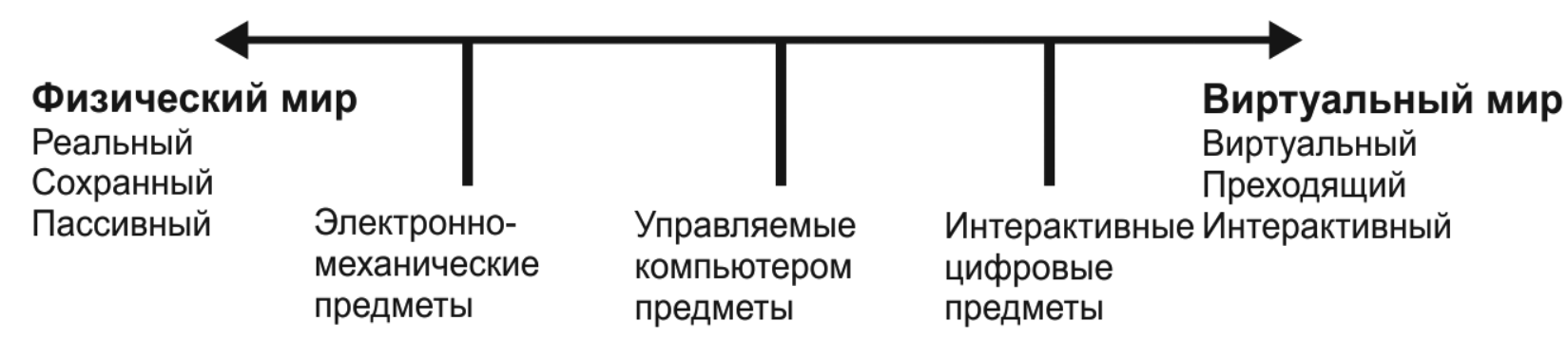
Fig. 1. Interrelation of tools and materials of artistic expression for various ratios of physical and
virtual level of realization of artistic objects in the context of convergent art. [1]

Законченный медиапродукт 
2.3 The Artistic potential of digital graphics as part of a continuous space of multimedia com puter arts.

The considered areas of application of digital media are corresponding to the general specifics of digital art which inextricably combines together digital media and computer technology that works with them, the concepts of traditional art that existed separately as a creative tool and raw artistic materials.

This type of connection allows the artist to move away from the straightforward transfer of traditional types and genres of fine art to the digital environment and engage in creative search in an integrated environment of digital art which combines a variety of modeling, visualization and parameterization tools including interactive.

Due to the deep mutual penetration of trans formed classical art forms in a multimedia digital environment, it is not surprising that certain types of art are blurred in the realities of the computer creative process. In modern conditions, the primary importance for the success of a digital art work is the management of its cycle of creation and exposure, taking into account the current realities of the socio-cultural environment. This factor is becoming a key one in terms of universal civilization the mechanisms of delivery and display of media content when the lack of availability and exclusivty of media copy (the traditional attributes of fine art) are no longer dominant factors in attracting interest to the product. The main point for the success of art events in such conditions is the creation of a sufficiently extensive and at the same time integral ideological and content environment which allows the visitor to get a fundamentally different aesthetic experience in relation to the clip-based everyday environment.

The diagram in Fig. 2 demonstrates the modern vision of the digital art creation cycle as a means of achieving global cultural goals - bringing the creative idea embodied in the means of artistic expression to the public, by using the optimization of the means of demonstration as an integral part of the cycle of creating an art object.

3. Convergence of traditional and multimedia

exhibition facilities in the display of digital art

3.1 The emergence and development of immersive art forms.

The effect of presence, the "immersion" of the viewer in the atmosphere created by the visual art- work was a desired goal long before the emergence of digital art. Large-scale pictorial panels, combining easel, monumental and decorative paintings in a single space, pictorial and graphic illusions, panoramas, means of projecting static images and cinema with increasing panoramas, up to full-dome projection - all these tools were used to enhance the impression of artistic works. However, only with the advent of multimedia tools of digital art, it became possible to achieve full-fledged immersiveness. Modern means of displaying works of digital art allow one to capture the viewer's attention most completely without extraordinary expenses for the production of graphic and accompanying content and for demonstration means, to convey the artistic intent by simultaneously affecting various senses and, if necessary, to supplement the impression with elements of interactivity.

The modern use of immersive exhibition spaces covers a wide range of variations [7], from the transformation of classical paintings into immersive exhibition spaces [8] and up to the creation of specialized multimedia works for an immersive en vironment. In addition to art exhibitions, immersive spaces are also successfully used in the scientific and educational exhibition environment.

3.2 Multidisciplinary museums as a new and

promising category of exhibition spaces.

Modern researchers note that the convergence of traditional and digital art is not limited to the use of modern technical means for the display of traditional art works, as well as to the use of traditional Museum spaces for the display of digital art forms. The museum and exhibition environment itself is undergoing transformation, as well as its place in culture and the social roles it plays. Multimedia multidisciplinary art spaces are free now from the shackles of the historical context that cements the environment of classical art. Modern art spaces are becoming a place for visual demonstration of socio-cultural transitions not limited to the use of the fruits of scientific and technological progress.

...the easy belief that the museum would find a connection with technological advances just by using the latest (media) technology" But the museum cannot just take over the latest technologies and continue as before. "It must break away from the prevailing historistic, colonial, and elitist thinking that still shapes many of our museums today". Not least of all, art museums are cultural history museums, and they age with the way they convey their collections. Therefore, "the spread of networking thought dethrones the monodisciplinary art museum that has long been considered the queen of museums". [6]

\section{Conclusion}

Digital graphic design has a huge artistic potential in relation both to classical types of visual art as well as to modern media art. The richness of modern digital means of artistic expression, their rapid progress responsive to all current trends and requests of the artistic environment, as well as the maximum productivity of creation, replication and distribution of works, contribute to the growth of the penetration of digital graphic modeling in the socio-cultural environment and the share of computer art in the total number of media products consumed by civilization.

Due to the interdisciplinary nature of computer art it is quite natural to observe a dense convergence of various types and applications of digital art in the modern artistic environment. Already at the stage of creating works of three-dimensional graphics, the simultaneous creation of three-dimensional models and images for animation and cinematography, as well as for static use as replicated paintings and sculptures is common for modern mass art, which exists in a highly competitive environment and uses multiple channels of monetization of created artistic images in various types of works united by a common artistic design.

The major art projects of the pre-digital era can serve as an example of the active use of various types of art in a complex interconnected system at the production stage. An indispensable element of the production of feature films is a graphic and sculptural conceptual study as the basis of which the scenery costumes and props of the film are made. In the course of the digital revolution in cinema which began in the 70s of the XX century and has almos ended by now, almost all stages of artistic elaboration of the visual elements of films have completely passed into the field of digital graphic design, replac ing in an increasing proportion of cases conceptual sculpture and graphics. Nowadays, digital graphic design has made up a large part of the visual range of modern cinema, replacing material decorations, props, complex types of makeup and costumes, in some cases fully implementing the landscape part of the film. The technological advantages of digita art - first of all, the ease of reuse and refinement of digital models in order to produce related series of works - allow one to minimize the cost of creating modern digital models, embodying in the most complex of them the work of significant teams of artists, designers and programmers.

In the field of organizing exhibition spaces there is a convergence of traditional and digital art displays. Traditional forms are presented along with direct demonstration of completed works of digita graphic modeling and works of interactive demonstration tools that involve the viewer directly in the artistic context of a multimedia work, which allows one to modify the artistic images of the objects on display in a fascinating way, to be included personally in the system of digital objects. In a modern society that is extremely saturated with a variety of audiovisual programs, the so-called "culture of passive entertainment", such multimedia and interactive exhibition spaces offer a representative of the widest audience in the most favorable format to form a positive integral impression of the art space, which contributes to the popularization of graphic art in general, strengthening its role as one of the fundamental components of modern culture.

Digital means of multimedia artistic communication are becoming particularly relevant in condition of prolonged social crises of moderate intensity when a significant part of the population still retains a secure interest in art, but trips, trips to visit museum and exhibition institutions, as well as holding mass cultural events are becoming difficult to access economically and often directly impossible. This applies both to large-scale pandemics such as the current COVID-19 pandemic, and to hybrid confrontations that are now widespread in the world which are expressed in long-term military and political conflicts of low intensity. Electronic means of $c$ tivities in these conditions allow art to overcome distances, barriers and restrictions, are helping to reduce social and international tensions and develop a global cultural space. 

1. Adérito Marcos, Computer artefact: the crucial element
in artistic practice in digital art and Culture, Revista Lusófona de Estudos Culturais, vol. 3, n. 2, 2017, pp 149-166

2. Kevin McCarthy, Arthur Brooks, Julia Lowell, Laura Zakaras. The performing arts in a new era. ISBNO-83303041-8, 2001

3. Kluszczynski, R.W. 2007. "From Film to Interactive Art: Transformations in Media Arts", MediaArtHistories, ISBN-13: 978-0-262-07279-3, MIT Press, pp. 208-227

4. http://businesstravelrussia.ru/news/abt-partner-news/ event-live-geymifikatsiya-v-ivente-10-zhivykh-keysov/ https://moscow.arttube.ru/event/vy-stavka-virtual-nye-zerkala-konstantina-hudyakova/

Bast G., Carayannis E. G., Campbell D. F. 2018 Introduction: The Future of Museums. In: Bast $G$ Carayannis E., Campbell D. (eds) The Future of Museums. Arts, Research, Innovation and Society. Springer, Cham. https://doi.org/10.1007/978-3-319-93955-1_1

Virtual art: from illusion to immersion, Oliver Grau ISBNO-262-07241-6 The MIT Press 2003

https://www.dailykos.com/

stories/2019/4/14/1835230/-Immersive-Art

профессор

зав. кафедрой «Средовой дизайн» Московской государственной художественно-промышленной академии им. С.Г. Строганова

e-mail: lenartt@gmail.com

Москва, Россия

ORCID 0000-0002-5355-8565

Дарья Евгеньевна Кардашенко преподаватель

Московская государственная художественно-промышленной академия им. С.Г. Строганов

e-mail: dkardashenko@gmail.com

Москва, Россия

ORCID 0000-0001-5707-5319

DOI: 10.36340/2071-6818-2021-17-4-110-123

\section{ХУДОЖЕСТВЕННЫЙ ПОТЕНЦИАЛ ГРАФИЧЕСКОГО ЦИФРОВОГО МОДЕЛИРОВАНИЯ.}

КОНВЕРГЕНЦИЯ ТРАДИЦИОННЫХ И МУЛЬТИМЕДИЙНЫХ

ВЫСТАВОЧНЫХ СРЕДСТВ В ДЕМОНСТРАЦИИ ПРОИЗВЕДЕНИЙ ЦИФРОВОГО ИСКУССТВА

Аннотация: В статье рассмотрен художественный потенциал компьютерного графического моделирования в пространстве современного художественного творчества и художественных систем экспонирования. Пример современных выставочных событий реализует сложную конвергенцию традиционных и мультимедийных экспозиционных средств в демонстрации произведений цифрового искусства. В основу методологии исследования был положен аналитический обзор проектных технологий художественных произведений и выставочных пространств, использующих цифровые модели, в контексте современных векторов медиа культуры и медиа искусства. В силу органически присущей компьютерному искусству междисциплинарности, становится естественна наблюдаемая в художественной среде плотная конвергенция различных видов и приложений цифрового искусства на фоне традиционных структур Намеченные современные тендении мултти -

\section{1. Введение}

В настоящей работе ставится задача анализа влияния современных возможностей цифрового графического моделирования на процесс создания художественных произведений. Областью медийной трансформации выставочных пространств и как результат, созданные полидисциплинарные экспосреды, позволяют говорить о глубоком проникновении цифровых технологий в область искусства и культуры. Примером становятся цифровые музеи с неограниченным потенциалом средств выражения: от ультратрадиционалистских объектов до примеров современных виртуальных пространств. Результатом проведенного исследования явилась выработка рекомендаций по оптимальной организации среды демонстрации гибридных и цифровых произведений искусства. Сделанные выводы позволяют учесть перспективы развития инновационных выставочных пространств, а также оптимизировать функционирование экспозиционной сред с растущей долей цифрового графического контента Ключевые слова: диджитал арт, мультимедийная выставка, VR/AR в GLAM, геймификация, цифровые технологии.

исследования является обзор текущего состояния иифрового графического искусства, его художе ственного потенциала, основных доступных выразительных средств, а также анализ перспектив демонстрации произведений цифрового искус 
ства в среде, сочетающей традиционные и мультимедийные выставочные средства.

1.1. Значение средств цифрового графического моделирования в современном искусстве.

Зародившись в 60-е гг. XX в., компьютерная графика прошла значительный путь развития, от ранних экспериментов для научно-технических нужд и отдельных спецэффектов в крупнобюджетных кинолентах в 70-80-х, до прочного утверждения в различных видах искусства, начиная с 90-х годов. Современная эпоха демонстрирует тотальное доминирование цифровых технологий на массовом рынке художественного контента. Это связано как с огромным разнообразием инструментов художественного выражения, предоставляемым современными средствами графического моделирования, так и с высокой производительностью труда цифровой среды. Влияют и фактор гибкой интегрируемости различных видов контента, и удобство взаимодействия между отдельными художниками. В совокупности это даёт переход на новый уровень художественной выразительности, одновременно радикально увели чивая количество ежегодно создаваемых в мире произведений. Существенное снижение стоимости и непосредственных трудозатрат художников, вызванное внедрением цифрового моделирования, позволяет коллективам умеренной численности успешно реализовывать анимационные и кинематографические проекты, которые ранее создавались с огромными затратами и в течение долгого времени большими коллективами. Аналогично, небольшие команды и даже дизайнеры-одиночки, оснащённые богатым арсеналом программно-аппаратных средств, справляются с недоступным в классическую эпоху объёмом архитектурного и средового творчества.

1.2. Тенденции конвергенции традиционных и мультимедийных выставочных средств, наблюдаемые в настоящее время

Взрывной рост проникновения цифровых

рафических технологий в процесс создания графических технологий в процесс создания художественных произведений влечёт за со-
бой необходимость создания новых выставочных пространств. Во многих случаях, цифровые технологии не заменяют традиционные художественные произведения и не создают специализированные цифровые выставочные пространства, а осуществляют конвергенцию традиционного и цифрового искусства в единой экспосреде. Это позволяет существенно расширить целевую ауди торию, разнообразить впечатления, получаемые посетителями, и получить их позитивный отклик на экспозицию, что способствует коммерческому успеху выставок и повышению общественной му успеху выставок и повышению об

\section{2. Области применения цифровых средств} графического искусства.

\section{1. Компьютерные игры.}

Первые компьютерные игры стали появляться вскоре после появления первых эВМ, как эксперименты компьютерных энтузиастов. Графиче ские возможности и доступность компьютеров стремительно росли, в 70-80 годы стали появстемы с двумерной графикой, а в 90-е появилас трёхмерная игровая графика. На рубеже веков мейнстримом стало применение аппаратных возможностей ускорения трёхмерной графики большинство игровых систем получило специализированный вычислитель - графический процессор с аппаратными возможностями ускорени рендеринга полигональной графики в реальном времени. В первом десятилетии XXI века видеокарты сначала получили возможность ускорения шейдинга, а к концу десятилетия стали высокопроизводительными многопоточными вычислителя ми для задач общего назначения. Применительно к задачам цифрового искусства подобный рос доступной вычислительной мощности привёл следующим основным тенденциям:

- Графический дизайн трёхмерных компьютерных игр стремительно усложняется, применя емые модели по сложности двигаются в сторону кинематографических, а качество получаемого

на выходе изображения постепенно стремится к фотореалистичному.

- Программные системы реализации игровой среды (т.н. «движки») становятся мощным инструментом создания трёхмерных интерактивных арт-объектов. Как в случае графических процессоров: массовость производства способствует невысокой стоимости аппаратных средств, а мас совость рынка игрового программного обеспече ния способствует доступности сложных средств разработки игр для применения даже в единичных арт-объектах.

- Внедрение элементов искусственного интеллекта в интерактивные выставочные объекть позволяет трансформировать выставочные пространства, делая участие посетителя в работе си- стемы максимально простым, позволяя вовлечь посетителя традиционного музея в виртуальную среду без его персонального обслуживания ассистентом при объекте. Современные средства ввода информации в компьютер, являющиеся развитием современных игровых устройств ввода позволяют осуществлять захват движения посетителя, распознавание лиц и прочих частей тела. Результатом обработки в режиме реального времени могут быть как статичные двумерные изображения, так и трёхмерная анимация с участием посетителя

- Большую роль в выставочных пространствах научно-популярного направления, таких как технические и естественнонаучные муз получают близкие к компьютерным играм системы интерактивной наглядной симуляции требуемых природных явлений и технических объектов. Современные музеи получают возможность создания с умеренными затратами аттракционов-тренажёров, дающих посетителю опыт нового уровня по сравнению с традиционными статическими экспонатами. Это позволяет эффективно вовлечь современного массового посетителя, привычного к изобилию доступного аудиовизуального контента. И особенно это важно для выставочных пространств, ориенти рованных на детскую и молодёжную аудиторию. С другой стороны - аппаратная и программная унификация интерактивного симулятора с трёхмерными игровыми системами предоставляе уникальные возможности создания доступных систем дистанционной интерактивной симуляции. Современное положение дел в данной области радикально отличается от ситуации 30-40 летней давности. Тогда компьютерная трёхмерная графика, и создаваемые на её основе интерактивные тренажёры-симуляторы требовали применения дорогостоящих графических станций и могли быть использованы либо только в месте своей установки (как правило, в промышленности, будучи недоступными для широкого выставочного применения в силу высокой стоимости), либо служить инструментами производства тиражируемых визуальных произведений без интерактивного использования. В настоящее ремя, напротив, активно внедря. Всся систем на основе массовых коммерчески доступных компонентов. Например, специалисты компании Wargaming, совместно с представителями Мини стерства обороны РФ разместили в 2016 г. в Цен- тральном музее Вооружённых сил РФ в Москв интерактивную мультитач-панель, где в деталях представлены исторически достоверные 3D-модели более полусотни боевых кораблей основных классов пяти сверхдержав эпохи мировых войн XX века. Посетителям дали возможность ознакомиться с 3D-моделями, каждую из которых можно было подробно рассмотреть с любого ракурса и под любым углом, поворачивая их из стороны в сторону, приближая и удаляя на сенсорном экране. В свою очередь, все модели сопровождались историческими справкам и тактико-техническими характеристиками. [4] Следует заметить, что данное выставочное средство повторяет собой часть функционала коммерческого продукта Wargaming - онлайн-игры "World of Warships», симулятора морских сражений, а создание подобного интерактивного стенда является весьма экономически выгодным в сравнении с автономной разработкой выставочного стенда с нуля, т. К. используются и готовый движок игры, и уже имеющийся в игре рафический контент.

- На стыке компьютерных игр и промышленной компьютерной графики возникли и получили бурное развитие системы виртуальной и дополненной реальности. Как и в случае с самими массовыми игровыми системами, снижени стоимости при переходе к массовому производству позволило сделать средства виртуальной реальности доступными широкой аудитории и сочетать стационарные музейные комплекс VR- и AR-демонстрации художественных произ ведений с дистанционными технологиями, основанными на отлаженных и популярных стандартах массовых игровых систем.

Государственный музей изобразительных искусств имени A. С. Пушкина внедрил AR-приложение Artefact, бесплатное для скачивания в App Store $n$ Google Play. Наводя камеру мобильно го устройства на экспонат, отмеченный знаком можно просмотреть всю информацию прямо на экране своего устройства - узнать исторически факты о нём или, например, сравнить, как произведение выглядело до реставрации и в процессе реставрационных работ. [4]

Кафедра Средовой дизайн (профили Средовой дизайн и Мультимедиа дизайны) академии им. С. Г. Строганова в рамках учебных программ «Гейм-дизайн», «Моушен-дизайн», «Проектирование», «Разработка интерфейсов», «Анимация 
активно стремится обращаться к современным тенденциям - создавать виртуальные выставочные пространства, доступные в форме интернет-сайтов, проектировать приложения дополненной реальности, позволяющие осуществлять цифровую трансформацию существующей природной, индустриальной или урбанистической среды под выставочные и просветительские нужды, а также придавать широкий мультимедийный функционал традиционным выставочным средам - выставкам, музеям, экскурсионным программам, модернизируя сложившиеся художественные формации под современные условия посредством медиа-реконструкции.

- Становление массовой игровой индустрии и её прочная культурная интеграция породи ли новое социальное явление в организации разнообразных социальных процессов - геймификацию. Сущность геймификации состоит в применении игровых элементов и механик за пределами собственно игрового процесса. Геймификация позволяет эффективно мотивировать людей, основываясь на естественных потребностях в элементе азарта, получении регулярного потока оцениваемых достижений и подобных источников эмоций, избегающих явного давления и прочих негативно воспринимаемых механизмов.

Геймификация с большим успехом внедряет ся в различных отраслях деятельности человека. Применительно к популяризаторской и образовательной функции музеев, геймификация позволяет заменить опросы и прочие формальные методы тестирования восприятия изученного материала игрой, в которой сам тестируемый посетитель заинтересован в демонстрации полученных знаний. В случае продолжительного погружения путём установки на личный смартфон приложения с элементами геймификации, потребитель сможет быть мотивирован на посещение и углублённую проработку целого ряда выставочных пространств. Примером стали разрабатываемые в рамках программы «Проектирование» интерактивные приложения.

2.2. Арт-инсталляции с использованием гафического цифрового моделирования

Компьютерные технологии зачастую выполняют не только вспомогательные технические функции по демонстрации произведений традиционного искусства или привнесения в выставочную среду интерактивности, но и могут состояться как самоценные арт-объекты. С каждым годом появляется всё большее количество художников, предпочитающих в своём творчестве использовать исключительно виртуальную среду. В качестве одного из примеров можно привести американского художник А. Джонса, который называет свои исключи тельно цифровые работы «зеркальным чисти лищем» и основной целью своего творчества считает изменение восприятия действительности и погружение человеческого сознания в виртуальную реальность.

Если творческие изыскания А. Джонса лежаг в основном в плоскости 2D-графики, то работы президента Творческого союза художников К. В. Худякова, которого называют «первопроходцем российской цифровой скульптуры» ос новываются на работе с трёхмерной графикой. «Oн заменил мрамор и резец на 3D Studio Max AutoCad и 3D принтер» [5]

2.3. Художественный потенциал цифровой графики как части непрерывного пространств мультимедийных компьютерных искусств.

Рассмотренные сферы применения цифровых средств соответствуют общей специфике цифрового искусства, неразрывно объединяющего в совокупности цифровых носителей информации и работающей с ними вычислительной техники существовавшие отдельно понятия традицион ного искусства, как творческий инструмент и необработанные художественные материалы.

Рис. 1. Взаимосвязь средств и материалов художественного выражения для различных соот ношений физического и виртуального уровня реализации художественных объектов в контексте конвергентного искусства. [1]

Такой характер связи позволяет художнику отойти от прямолинейного переноса традици онных видов и жанров изобразительного искус ства в цифровую среду, а заниматься творческим поиском в интегральной среде цифрового искусства, объеди инструменты моделирования, визуализации и параметризации, в том числе интерактивной.

В силу глубокого взаимного проникновения трансформированных классических художественных форм в условиях мультимедийной цифровой среды, неудивительно размытие отдельных видов искусства в реалиях компьютерного творческого процесса. В современных условиях первостепенное значение для успеха цифрового художествен- ного произведения приобретает управление его циклом создания и экспонирования с учётом актуальных реалий социокультурной среды. Данный фактор становитса ключевым в условиях всеобщего охвата цивилизации механизмами доставки и демонстрации медиаконтента, когда и дефицит доступности просмотра, и эксклюзивность медиакопии (атрибуты традиционного изобразительного искусства) больше не являются доми нирующими факторами привлечения интереса к произведению. Принципиальным моментом для успеха арт-ивентов в таких условиях становится создание достаточно обширной и одновременно целостной идейно-контентной среды, позволяющей посетителю получить принципиально иной, по отношению к клиповой повседневной среде, эстетический опыт.

Рис. 2 Общие факторы создания художественного произведения как интегрированного в культурную среду средства достижения отклика широкой аудитории [1]

Схема на рис. 2 демонстрирует современное видение цикла создания цифрового художе ственного произведения как средства достижения глобальных культурных целей - донесения творческого замысла, воплощённого в средствах художественного выражения, до общественности, путём задействования оптимизации средств демонстрации как неотъемлемой части цикла создания арт-объекта.

3. Конвергенция традиционных и мультим. Конй втставочных средств в демонстрации произведений цифрового искусства

3.1. Возникновение и развитие иммерсив ных форм искусства.

Эффект присутствия, «погружения» зрителя в создаваемую изобразительным художественным произведением атмосферу, был желанной целью задолго до возникновения цифрового искусства. Масштабные живописные панно, комбинирование станковой, монументальной и декоративной живописи в едином пространстве живописные и графические иллюзии, панорамы, средства проекционной демонстрации статических изображений и кинематограф с нарастающей панорамностью, вплоть до полнокупольной проекции - все эти инструменты использовались для усиления впечатления от художественных произведений. Однако, лишь с появлением мультимедийных средств цифрового искусства, стало возможным достижение полноценной иммерсив- ности. Современные средства демонстрации про изведений цифрового искусства позволяют без экстраординарных затрат на производство гра作 вниманием зрителя, доносить художественный замысел одновременным воздействием на различные органы чувств, а при необходимости дополнять получаемые впечатления элементами интерактивности.

Современное применение иммерсивных выставочных пространств охватывает широчайший спектр вариаций [7], от трансформации произ ведений классической живописи в иммерсивные выставочные пространства [8] до создания специализированных мультимедийных произведений для иммерсивной среды. Помимо художественных выставок, успешное применение иммерсивные пространства находят и в научно-просветительской экспозиционной среде.

3.2. Мультидисциплинарные музеи как новая и перспективная категория выставочных пространств.

Современные исследователи отмечают, что конвергенция традиционного и цифрового ис кусства не сводится лишь к применению современных технических средств для демонстрации традиционных художественных произведений, равно как и к использованию традиционных музейных пространств для демонстрации цифровых форм искусства. Трансформации подвергается как сама музейно-выставочная среда, так и её место в культуре, выполняемые ею социальные роли. Мультимедийные мультидисциплинарные художественные пространства динамично освобождаются от оков исторического контекста, цементирующего среду классического искусства. Современные художественные пространства становятся местом наглядной демонстрации соци окультурных переходов, не ограничиваясь лиш применением плодов научно-технического прогресса.

"...the easy belief that the museum would find a connection with technological advances just by using the latest (media) technology" But the museum cannot just take over the latest technologies and continue as before. "It must break away from the prevailing historistic, colonial, and elitist thinking that still shapes many of our museums today". Not least of all, art museums are cultural history museums, and they age with the way they convey their collections. 
Therefore, "the spread of networking thought dethrones the monodisciplinary art museum that has long been considered the queen of museums".[6]

\section{4. Заключение}

Цифровой графический дизайн обладает огромным художественным потенциалом как применительно к классическим видам изобразительного искусства, так и в отношении современного медиа-искусства. Богатство современных цифровых средств художественного выражения их быстрый прогресс, чутко реагирующий на все актуальные тенденции и запросы художественной среды, а также максимальная производительность создания, тиражирования и распространения произведений, способствуют росту проникновения цифрового графического моделирования в социокультурную среду и доли компьютерноо искусства в общем количестве потребляемых цивилизацией медиа-продуктов.

В силу органически присущей компьютерному искусству междисциплинарности, совершенно естественна наблюдаемая в современной художественной среде плотная конвергенция различ ных видов и приложений цифрового искусства. Уже на стадии создания произведений трёхмерной графики широко распространено одновременное создание трёхмерных моделей и образов как для анимации и кинематографии, так и для статичного использования в качестве тиражиру емых картин и скульптур - характерно для современного массового искусства, существующего в условиях высоко конкурентной среды и использующего множественные каналы монетизации создаваемых художественных образов в различ ных видах произведений, объединённых общим художественным замыслом.

Примером активного использования различ ных видов искусства в сложной взаимосвязанной системе на стадии производства становилис крупные художественные проекты доцифровой эпохи. Непременным элементом производства игрового кино является графическая и скульптурная концептуальная проработка, на основании которой выполняются декорации, костюмы и реквизит киноленты. В ходе цифровой революции в кинематографе, начавшейся в 70-х годах XX в. и почти завершившейся к настоящему времени практически все этапы художественной проработки изобразительных элементов кинофильмов полностью перешли в область цифрового графи ческого дизайна, заменяющего во всё большей доле случаев концептуальные скульптуру и графику. В настоящее время, цифровой графический дизайн составил большую часть визуального ряда современного кино, заменяя материальные декорации, реквизит, сложные виды грима и костюмь в ряде случаев, полностью реализуя ландшафтную часть киноленты. Технологические преи мущества цифрового искусства 一прежде всего лёгкость повторного использования и доработок цифровых моделей с целью выпуска связанных серий произведений, позволяют минимизировать затраты на создание современных цифровых моделей, воплощая в наиболее сложных из них труд значительных коллективов художников, дизайнеров и программистов.

В области организации выставочных пространств наблюдается конвергенция демонстрации традиционных и цифровых видов искусств. Традиционные виды представлены наряду с непосредственной демонстрацией законченных произведений цифрового графического модели рования и работ интерактивных средств демонстрации, вовлекающих зрителя непосредственно в художественный контекст мультимедийного произведения, что позволяет в увлекательной форме модифицировать художественные образы экспонируемых объектов, лично включатьс в систему цифровых объектов. В современном обществе, крайне насыщенном разнообразными аудиовизуальными программами, т. н. «культуре пассивного развлечения», подобные мультимедийно-интерактивные выставочные пространства предлагают представителю самой широкой аудитории в наиболее благоприятном формате сформировать позитивное интегральное впе чатление от художественного пространства, что способствует популяризации графического искусства в целом, укрепляя его роль, как одной из фундаментальных составляющих современной культуры.

Особо актуальными становятся цифровые средства мультимедийной художественной коммуникации в условиях затяжных социальных кризисов умеренной интенсивности, когда значительная часть населения ещё сохраняет обеспеченны интерес к искусству, но поездки, путешествия с целью посещения музейно-выставочных учреждений, а также проведение массовых культурных мероприятий становятся и труднодоступными экономически, и нередко прямо невозможными организационно. Это относится как к масштабным пандемиям, как имеющая место в настоящее время пандемия COVID-19, так и к распространённым сейчас в мире гибридным противостояниям выражающимся в долговременных военно-политических конфликтах низкой интенсивности. Электронные средства коммуникации и виртуаль-

БИБЛИОГРАФИЯ

1. Adérito Marcos. Computer artefact: the crucial element in artistic practice in digital art and Culture, Revista in artistic practice in digital art and Culture, Revista 2017. - P. 149-166.

2. The performing arts in a new era / Kevin McCarthy, The performing arts in a new era / Kevin McCarthy,
Arthur Brooks, Julia Lowell, Laura Zakaras. - ISBNOArthur Brooks, Julia Low

3. Ryszard W. Kluszczynski From Film to Interactive Art Transformations in Media Arts/MediaAthistories; 2006. - P. 208-227. ной выставочной деятельности в этих условиях позволяют искусству преодолевать расстояния, барьеры и ограничения, способствовать снижести, развивать глобальное культурно-ценностное пространство. http//businesstravelrussia.ru/news/abt-partner-news/ event-live-geymifikatsiya-v-ivente-10-zhivykh-keysov/ 5. https://moscow.arttube.ru/event/vy-stavka-virtual-nye-zerkala-konstantina-hudyakova/

Rest G. et al. (eds.). The Future of Museums, Arts, Rearch, Innovation and Society. - URL: https://do org/10.1007/978-3-319-93955-1_

. 8.

stories/2019/4/14/1835230/-Immersive-Art 
Журнал зарегистрирован в государственном комитете РФ по печати. Свидетельство о регистрации СМИ - ПИ № ФС77-27658

от 30 марта 2007

Полнотекстовая электронная версия доступна на сайтах:

www.burganova-text.com

www.elibrary.ru

Подписка на журнал во всех отделениях связи России и стран СНГ. Подписной индекс 36947

Иллюстрации публикуются в соответствии со статьей 1274

гражданского кодекса РФ «Свободное использование произведения

в информационных, научных, учебных или культурных целях»

Информация для авторов, условия приема публикации на сайте:

www.burganova-text.com

\section{Переводчик Анна Вадимовна Пчёлкина}

Корректор Светлана Николаевна Михайлова

Верстка Владислав Борисович Андреев

\section{Журнал выходит 5 раз в год}

Адрес редакции:

19019, Москва, Б. Афанасьевский переулок, д. 15, стр. 9

Тел.: 8495 695-04-29

www.burganova-text.com

dom.text@gmail.com

Тираж 500 экз.
Journal Burganov House. Space of Culture is registered in State Press

Committee of the Russian Federation on March 30, 2007.

The mass media registration certificate ПИ № ФС 77-27658

The journal is in the List of peer-reviewed scientific publications of the Higher Attestation Commission of the Ministry of education and science of the

Russian Federation

Full-text electronic version is available at the sites:

www.burganova-text.com

www.elibrary.ru

Subscription to the journal in all post offices of Russia

and the CIS countries. Subscription index under the catalogue

"Post of Russia" is 36947

Illustrations are published in accordance with Article 1274 of the The Russian Civil Code "Free Use of the Work for informational, scientific, educational or cultural purposes"

Information for authors, conditions for accepting publications is on the site: www.burganova-text.com

Translator Anna V. Pchelkina

Proofreader Svetlana N. Mikhailova

Layout Vladislav B. Andreev

\section{The journal is published 5 times a year}

Editorial office address in Russia:

Russia, Moscow. 19019, B. Afanasyevsky lane, d. 15, p. 9

tel .: 007495 695-04-29

Editorial office address in $\mathrm{EU}$ :

Belgium, Brussels, 1000, rue de la tete d'or,

tel.: +32485681863

www.burganova-text.com

dom.text@gmail.com

Circulation: 500 copies 